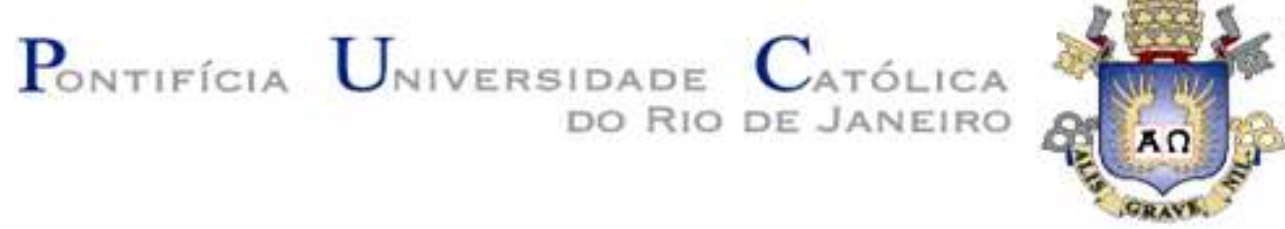

Gleyce Assis da Silva Barbosa

\title{
A mobilidade espacial docente: uma análise da precarização do trabalho
}

Dissertação de mestrado

Dissertação apresentada como requisito parcial para obtenção de grau de Mestre pelo Programa de PósGraduação em Geografia do Departamento de Geografia e Meio Ambiente do Centro de Ciências Sociais da PUC-Rio.

Orientadora: Profa. Rejane Cristina de Araujo Rodrigues

Rio de Janeiro, Novembro de 2020 


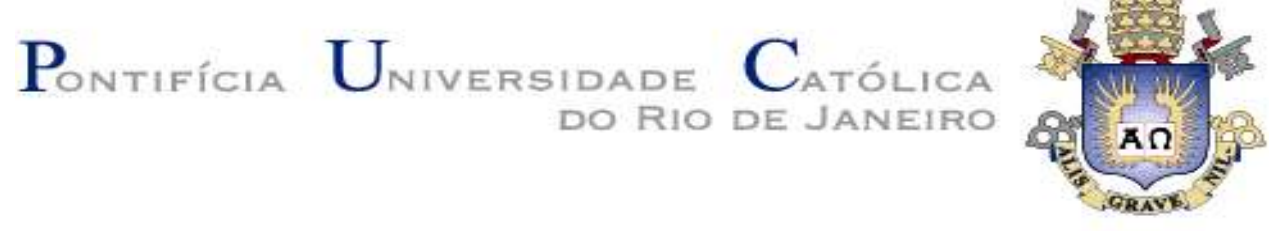

Gleyce Assis da Silva Barbosa

\author{
A mobilidade espacial docente: \\ uma análise da precarização do trabalho
}

Dissertação apresentada como requisito parcial para obtenção de grau de Mestre pelo Programa de PósGraduação em Geografia do Departamento de Geografia e Meio Ambiente do Centro de Ciências Sociais da PUC-Rio. Aprovada pela Comissão Examinadora abaixo:

Profa. Rejane Cristina de Araujo Rodrigues

Orientadora Departamento de Geografia - PUC-Rio

Prof. Roberto Marques

Faculdade de Educação - UFRJ

Prof. Eduardo José Pereira Maia Departamento de Geografia - UFRJ 
Todos os direitos reservados. A reprodução, total ou parcial, do trabalho é proibida sem autorização da universidade, da autora e do orientador.

\section{Gleyce Assis da Silva Barbosa}

Graduou-se em Licenciatura em Geografia na UFRJ (Universidade Federal do Rio de Janeiro) em 2015. Participou durante três anos do projeto PIBID-UFRJ, onde desenvolveu pesquisa e atividades relacionadas ao ensino de Geografia. Ajudou na organização de eventos acadêmicos e curso de extensão. Atuou como monitora de diversas disciplinas. Participou de congressos nacionais na área de Geografia. Atualmente integra o Núcleo de Estudos em Cidadania e Política no Ensino de Geografia (NECPEG) e o grupo de pesquisas sobre Espaço, Cotidiano, Educação e Docência (ECED). Atua como professora nos anos finais do ensino fundamental e no ensino médio em escolas e cursos da Baixada Fluminense.

Ficha Catalográfica

Barbosa, Gleyce Assis Da Silva

A mobilidade espacial docente: uma análise da precarização do trabalho / Gleyce Assis Da Silva Barbosa; orientadora: Rejane Cristina de Araujo Rodrigues. - 2020. Departamento de Geografia, 2020.

196 f. : il. color. ; $30 \mathrm{~cm}$

1. Dissertação (mestrado) - Pontifícia Universidade Católica do Rio de Janeiro, Departamento de Geografia e Meio Ambiente, 2020.

Inclui bibliografia

1. Geografia e Meio Ambiente - Teses. 2. Mobilidade. 3. Trabalho docente. 4. Precarização. 5. Metropolização. 6. Microrregião metropolitana do Rio de Janeiro. I. Rodrigues, Rejane Cristina de Araujo. II. Pontifícia Universidade Católica do Rio de Janeiro. Departamento de Geografia e Meio Ambiente. III. Título. 
Para os professores da educação básica por sua gigantesca importância para esse país e para minha mãe, pois onde quer que esteja olha por mim. 


\section{Agradecimentos}

O presente trabalho foi realizado com apoio da Coordenação de Aperfeiçoamento de Pessoal de Nível Superior - Brasil (CAPES) - Código de Financiamento 001.

À minha orientadora Professora Rejane Rodrigues pela paciência, incentivo, cobrança, dicas e parceria para a realização deste trabalho.

Ao meu pai pela educação e amor. À minha avó pelas marmitas deliciosas e por todo apoio. À minha irmã pela paciência, atenção e carinho de todas as horas.

Ao meu grande amigo Gilson, por ter me incentivado a tentar o mestrado nesta instituição, pela ajuda com os mapas, dicas e pela amizade.

Ao meu namorado Felipe e às amigas que a PUC me deu, Leydiane e Juliana, por todo apoio, auxílio, dicas e compreensão.

Aos professores Roberto Marques e Eduardo Maia, pela ajuda, dicas, palavras de apoio e por aceitarem participar da Comissão examinadora.

Aos integrantes dos grupos NECPEG e ECED pelas valiosas contribuições.

Aos meus colegas da PUC-Rio, aos professores e funcionários do Departamento pelos ensinamentos e pela ajuda e à Secretária Márcia Coutinho, pela gentileza e pelas diversas vezes que me ajudou nesses dois anos.

E a todos os amigos e familiares que de uma forma ou de outra me estimularam ou me ajudaram. 


\section{Resumo}

Barbosa, Gleyce Assis da Silva; Rodrigues, Rejane Cristina de Araujo. A mobilidade espacial docente: uma análise da precarização do trabalho. Rio de Janeiro, 2020. p. Dissertação de Mestrado - Departamento de Geografia e Meio Ambiente, Pontifícia Universidade Católica do Rio de Janeiro.

A reestruturação produtiva marca, dentre diversos aspectos, a intensificação global dos fluxos e a ampliação da flexibilização do trabalho. Esse processo atingiu diferentes setores, inclusive a educação mediante a mercantilização do ensino e a ascensão do neoliberalismo. Desse modo, assistimos a sucessivos cortes de verbas para o ensino público, a deterioração do sistema educacional básico, as modificações na legislação trabalhista que colaboraram para a intensificação da precarização, atingindo sobretudo os docentes. Assim, a existência de um regimento legal flexível e de sistemas diferenciados de remuneração e carga horária entre as esferas administrativas permitiu a categoria o acúmulo de empregos para alcance de salários razoáveis, o que de um lado mascarou a pauperização do trabalho e de outro corroborou para o surgimento de diversos problemas de âmbito operacional, laboral e urbano, como o intenso fluxo espacial pendular interescolas. Nesse sentido, o objetivo desta pesquisa é, portanto, analisar a mobilidade dos professores como parte do processo precarização do trabalho. Desse modo, a pesquisa dividese em uma tríade: compreender as ações que ocasionam a precarização; entender o que é a mobilidade e a sua relação com a produção do espaço; mapear a espacialidade dos fluxos intraurbanos destes indivíduos (casa-escola e interescolas) apontando sua natureza. Para melhor delimitação do tema optou-se como recorte empírico os docentes dos anos finais do ensino fundamental e médio que atuam na Microrregião Metropolitana do Rio de Janeiro, pois além de comportar grande quantitativo de professores, trata-se de uma área conurbada, constituída de fluxos pendulares que se relacionam aos arranjos populacionais derivados do processo de metropolização. Nesse sentido, escolheu-se utilizar diversas fontes estatísticas disponibilizadas pelo INEP, sobretudo os microdados do Censo Escolar para compreender a problemática na dimensão macro. Também se optou pela aplicação de questionário aos docentes para entender a percepção destes indivíduos na esfera micro, ou seja, do cotidiano.

\section{Palavras-chave}

Mobilidade; trabalho docente; precarização; metropolização. 


\section{Abstract}

Barbosa, Gleyce Assis da Silva; Rodrigues, Rejane Cristina de Araujo. The spatial mobility of teacher: an analysis of the precariousness of work. Rio de Janeiro, 2020. p. Master's Dissertation - Department of Geography and Environment, Pontifical Catholic University of Rio de Janeiro.

The productive restructuring marks, among several aspects, the global intensification of flows and the expansion of work flexibility. This process reached different sectors, including education through the commercialization of teaching and the rise of neoliberalism. In this way, we have seen successive cuts in funds for public education, deterioration of the basic educational system, legal changes in labor legislation that have contributed to the intensification of precariousness, especially affecting teachers. Thus, the existence of a flexible legal regulation and differentiated systems of remuneration and workload between administrative spheres allowed the category to accumulate jobs to achieve reasonable salaries, which on the one hand masked the impoverishment of work and on the other corroborated for the emergence of several operational, labor and urban problems, such as the intense inter-school pendulum spatial flow. In this sense, the objective of this research is, therefore, to analyze the mobility of teachers as part of the precarious work process. Thus, the research is divided into a triad: to understand the actions that cause precariousness; understand what mobility is and its relationship with the production of space; map the spatiality of intra-urban flows of these individuals (home-school and inter-school) pointing out their nature. For a better definition of the theme, the empirical approach was chosen by teachers from the final years of elementary and high school who work in the Metropolitan MicroRegion of Rio de Janeiro, because in addition to having many teachers, it is a conurbated area, consisting of pendulum flows that relate to population arrangements derived from the metropolization process. In this sense, it was chosen to use several statistical sources made available by INEP, especially the microdata from the School Census to understand the problem in the macro dimension. It was also chosen to apply a questionnaire to teachers to understand the perception of these individuals in the micro sphere, that is, in the everyday.

\section{Keywords}

Mobility; teaching work; precariousness, metropolization. 


\section{Sumário}

1.Introdução 14

1.1. Objetivos 23

1.2. Questões e hipóteses 23

1.3. Procedimentos metodológicos 24

1.4. Sobre as fontes de dados $\quad 40$

1.5. Limites e riscos da pesquisa 44

1.6. Referencial teórico $\quad 51$

2. O trabalho docente no século XXI: a precarização em pauta 52

2.1 Notas sobre o trabalho 53

2.2 A precarização do professor no Brasil 64

2.3 A legislação trabalhista e as políticas públicas relacionadas ao trabalho $\begin{array}{ll}\text { docente } & 77\end{array}$

3. A Mobilidade espacial enquanto categoria de análise 100

3.1 Elementos teóricos para compreensão da mobilidade: definição, tipologia, modelos de análise 101

$\begin{array}{ll}3.2 \text { Correntes teóricas da mobilidade } & 108\end{array}$

3.3 Mobilidade, Geografia e Teoria Socioespacial 112

$\begin{array}{ll}3.4 \text { Metropolização e mobilidade } & 124\end{array}$

4- Mobilidade e precarização docente na Microrregião Metropolitana do Rio de Janeiro

134

4.1 Perfil docente e condições de trabalho na MMRJ 135

4.2 Análise espacial da mobilidade docente na MMRJ 148

4.3 A mobilidade docente no cotidiano 166

$\begin{array}{ll}\text { 5. Considerações finais } & 175\end{array}$

6. Referências Bibliográfica 179 


\section{Lista de siglas e abreviaturas}

ABEB - Anuário Brasileiro da Educação Básica

ALERJ - Assembleia Legislativa do Estado do Rio de Janeiro

BNCC - Base Nacional Comum Curricular

CBO - Classificação Brasileira de Ocupações

CAGED - Cadastro Geral de Empregados e Desempregados

CAQ - Custo Aluno Qualidade

CF - Constituição Federal

CLT - Consolidação das Leis Trabalhistas

CNTE - Confederação Nacional dos Trabalhadores em Educação

CTVA - Carteira de Trabalho Verde e Amarela

EAG - Education At a Glance

FAPERJ - Fundação de Amparo à Pesquisa do Estado do Rio de Janeiro

FAT - Fundo de Amparo ao Trabalhador

FUNDEB - Fundo de Manutenção e Desenvolvimento da Educação Básica

e de Valorização dos Profissionais da Educação

FUNDEF - Fundo de Manutenção e Desenvolvimento do Ensino

Fundamental e de Valorização do Magistério

GLP - Gratificação por Lotação Prioritária

IBGE - Instituto Brasileiro de geografia e Estatística

INEP - Instituto Nacional de Estudos e Pesquisas Educacionais

INPC - Índice Nacional de Preços ao Consumidor

LDB - Lei de Diretrizes e Bases

MEC - Ministério da Educação

MMRJ - Microrregião Metropolitana do Rio de Janeiro

MP - Medida Provisória

MTE - Ministério do Trabalho e Emprego

MTPS - Ministério do Trabalho e Emprego e Previdência Social

OCDE - Organização para a Cooperação e Desenvolvimento Econômico

ONG - Organização não governamental

PDE - Plano de Desenvolvimento da Escola

PEC - Proposta de Emenda Constitucional

PIB - Produto Interno Bruto

PNAD - Pesquisa Nacional por Amostra de Domicílios

PNE - Plano Nacional de Educação

PSPN - Piso Salarial Profissional Nacional

RAIS - Relação Anual de Informações Sociais

RMRJ - Região Metropolitana do Rio de Janeiro

SAEB - Sistema de Avaliação da Educação Básica

SEEDUC - Secretaria de Estado de Educação

SIDRA - Sistema IBGE de Recuperação Automática

TALIS - Teaching And Learning International Survey 
TCE-RJ - Tribunal de Contas do Estado do Rio de Janeiro

TST - Tribunal Superior do Trabalho

UERJ - Universidade Estadual do Rio de Janeiro

UNESCO - Organização das Nações Unidas para a Educação, a Ciência e a Cultura

\section{Lista de Quadros}

Quadro 1- indicadores e fontes utilizados na pesquisa

Quadro 2 - Variáveis de deslocamento selecionadas na plataforma

SIDRA/IBGE.

Quadro 3 - Nomenclaturas do indicador de esforço docente. 30

Quadro 4 - Indicadores de esforço docente. 30

Quadro 5 - Variáveis para levantamento da média remuneração docente.32

Quadro 6 - Variáveis para levantamento da admissão e demissão. $\quad 33$

Quadro 7 - Variáveis escolhidas nos microdados do Censo Escolar. $\quad 34$

Quadro 8 - Critérios metodológicos para o deslocamento pendular docente.

Quadro 9 - Classificação da intensidade relativa dos fluxos. 36

Quadro 10 - Variáveis levantadas no questionário. 136

Quadro 11 - Panorama das respostas do questionário online. 169

\section{Lista de Tabelas}

Tabela 1 - Comparação entre o rendimento médio dos professores da Educação Básica e de profissionais de outras áreas com curso superior 67 Tabela 2 - Docentes na Educação Básica por quantidade de estabelecimentos que lecionam.

Tabela 3 - Classificação global das melhores e piores cidades para deslocamento.

Tabela 4 - Distribuição de docentes pelo $\mathrm{n}^{\circ}$ de escolas que atua, pelo sexo e faixa etária.

Tabela 5 - Distribuição de docentes por ํㅜ de escolas que atua e por disciplina que leciona.

Tabela 6 - Distribuição de docentes pelo no de escolas que atuam e o nível de formação. 158

Tabela 7 - Distribuição docente pelo tipo de contratação. 159 Tabela 8 - Percentual de professores que atuam em duas escolas da mesma rede de ensino no mesmo município. 162 Tabela 9 - Tempo médio de deslocamento por semana dos professores entrevistados. 


\section{Lista de Gráficos}

Gráfico 1 - Indicador de esforço docente estado do Rio de Janeiro - anos iniciais.

Gráfico 2 - Indicador de esforço docente estado do Rio de Janeiro - anos finais

Gráfico 3 - Indicador de esforço docente estado do Rio de Janeiro - ensino médio.

Gráfico 4 - Proporção de alunos por equipe escolar (professor e auxiliares) no ensino médio nos países da OCDE.

Gráfico 5 - Percentual de professores que disseram achar que a profissão de professor é valorizada pela sociedade - anos finais ensino fundamental.

Gráfico 6 - Percentual de professores que disseram achar que a profissão de professor é valorizada pela sociedade - Ensino Médio. Gráfico 7 - Evolução histórica da execução das despesas na área de atuação de educação.

Gráfico 8 - Porcentagem de trabalhadores que se deslocam para trabalho na MMRJ por tempo gasto e por faixas de horas habitualmente trabalhadas por semana no trabalho principal.

Gráfico 9 - Deslocamento para o trabalho na MMRJ por classe de rendimento mensal nominal per capita e local do trabalho principal. 129 Gráfico 10 - Pirâmide etária docente na RMRJ 2018. Gráfico 11 - Tipo de contratação na RMRJ 140 Gráfico 12 - Comparação dos municípios da Região Metropolitana por tipos de contratação

Gráfico 13 - Evolução da contratação e demissão na MMRJ.

Gráfico 14 - Evolução do número de docentes na MMRJ (somatório dos anos finais e ensino médio).

Gráfico 15 - Evolução do número de matrículas na MMRJ (somatório dos anos finais e ensino médio). 144

Gráfico 16 - Indicador de esforço docente na MMRJ - anos finais. 145

Gráfico 17 - Indicador de esforço docente na MMRJ - ensino médio. 146

Gráfico 18 - Evolução salarial de professores na MMRJ. 147

Gráfico 19 - Comparação da média salarial de professores com o INPC.147 Gráfico 20 - Remuneração média nominal por município da RMRJ. 156 


\section{Lista de mapas}

Mapa 1: Mapa de intensidade dos deslocamentos para trabalho e estudo na Concentração Urbana do Rio de Janeiro/RJ. 27

Mapa 2: Pessoas que trabalham fora do município onde moram. 131

Mapa 3: Distribuição docente na MMRJ por rede de ensino. 149

Mapa 4: Local de moradia dos professores que atuam na MMRJ. $\quad 150$ Mapa 5: Deslocamento docente nos municípios da MMRJ - direção casatrabalho.

151

Mapa 6: Intensidade do deslocamento docente na MMRJ - direção casatrabalho. 152

Mapa 7: Docentes que trabalham fora do município onde moram. 154 Mapa 8: movimento pendular intrametropolitano de professores que residem no RJ e trabalham na MMRJ. 155

Mapa 9: percentual de professores que atuam em até duas escolas do mesmo município.

Mapa 10: deslocamento docente interescolas na MMRJ - docentes que atuam em até duas escolas.

\section{Lista de Anexos}

Anexo 1: Perguntas e Respostas do questionário 190

Anexo 2: número de escolas na RMRJ 194

Anexo 3: distribuição docente por rede de ensino, sexo e faixa etária na MMRJ

Anexo 4: distribuição docente por disciplina e escolaridade na MMRJ 195 Anexo 5: distribuição docente por tipo de contratação na MMRJ. 
"Diga-me onde está o trabalho em um tipo de sociedade e eu te direi onde está a educação."

Emir Sader - Prefácio de A educação para além do capital (MÈSZÁROS, 2008, p.17) 


\section{Introdução}

Nos últimos cinquenta anos, assistimos a diversas transformações estruturais no que se refere às formas de produção, à organização do trabalho e à circulação. Como resultado da crise do modelo de acumulação fordista que perpetuou até meados do século XX, surge o modelo flexível articulando o espaço, conectando cidades em todo mundo e tendo como principal característica os grandes fluxos de capitais, mercadorias e pessoas (Harvey, 1992).

Antunes (2000) explica que é a partir do surgimento do capitalismo integrado que estratégias para uma reestruturação produtiva do trabalho passam a disseminar transformações em uma escala global como a flexibilização, a digitalização do trabalho, a privatização monumental do setor de serviços, o crescimento exponencial do mercado financeiro, colaborando com a rápida expansão da proletarização, ou seja, o crescimento da mão de obra assalariada e a redução da mobilidade social.

Sobre isso, Santos (1994) afirma que a divisão do trabalho (internacional, nacional e local) redefiniu o espaço em todos os seus níveis de organização e em todas as escalas e que é a primeira vez ao longo da história que essa organização do trabalho se deu de forma deliberada, pré-determinada e fruto de intencionalidades, em que organismos internacionais influem na particularidade e nos modos de vida de cada país, por exemplo.

A partir disso, temos as novas tecnologias surgidas com o avanço da globalização e da produção cada vez mais acelerada criando relações laborais, destituindo frequentemente postos de trabalho, ao mesmo tempo que, para atender as necessidades deste mercado, surgiram novas profissões, embora em número muito restrito em relação aos postos de trabalho gerados outrora.

Ou seja, a inserção das ditas novas tecnologias e da acumulação flexível, significaram a exigência de um trabalhador flexível, multifacetado, com dedicação integral na execução das tarefas e capacidade de realizar várias operações simultâneas. Diante deste quadro, os empregadores passaram a exercer um controle mais intenso sobre a força de trabalho, dado o enfraquecimento dos trabalhadores, do poder sindical e do aumento dos índices de desemprego. (FERNANDES \& ORSO, 2014, p.3)

Portanto, o trabalho se torna um dos elementos mais importantes no mundo atual para se entender a expansão geográfica do capital e suas crises (HARVEY, 1992). Sabe-se que essas formas de trabalho não são recentes; Braga (2017) conta que no 
início do século XX, por exemplo, o roubo de direitos praticados por determinados grupos industriais em relação aos trabalhadores das fábricas era de certa forma um impedimento desse avanço do capital sob o trabalho. Com a maior disponibilidade da força de trabalho, a expansão tornou-se mais fácil através da implementação de novas formas de contratação como o trabalho intermitente, parcial, temporário, terceirizado e outros.

A alienação também é incorporada neste processo, pois mascara a realidade enquanto vendem essas formas de trabalho como modernas e que permitem maior autonomia e liberdade, escondendo a face dolorosa como jornadas exaustivas, adoecimento, instabilidade, insegurança, entre outras. A novidade é que na fase atual do capital há uma forte tendência exitosa de difundir estas formas de contratação, antes vista como exceção, porém agora entendida como regra a ser incorporada por todos os setores. É claro que, em algumas áreas, dependendo da força de organização sindical, ainda há maior proteção, mas, em outros setores que não possuem sindicatos, em geral aqueles que demandam menor qualificação ou funções recém-criadas, a fragilidade de engajamento amplia a degradação laboral. Essa fase de reestruturação produtiva teve como seu grande difusor político o neoliberalismo que no Brasil começou a ser implementado a partir dos anos 1990 através de ações dos agentes políticos e econômicos, promovendo a abertura econômica, a desregulamentação de leis de proteção ao trabalho e a privatização estatal, tendo como consequência direta o aumento do desemprego formal, o crescimento da informalidade, reduções salariais significativas, entre outras.

É nesse contexto que a precarização ganha força, pois favoreceu a criação de uma rede de subcontratação com o objetivo de se ter maior competitividade no mercado de trabalho. Segundo Antunes (2000), essas mudanças e as crises do sistema de trabalho reduziram substancialmente a contratação de trabalhadores, acarretando na maior disposição dessa mão de obra, que por sua vez resultou no que Druck (2002) chama de subproletarização do trabalho, podendo ser definido como o trabalho precário, o temporário, o parcial e a terceirização, todos diminuindo substancialmente a condição de estabilidade do trabalhador efetivo.

O neoliberalismo e a reestruturação produtiva da era da acumulação flexível, dotadas de forte caráter destrutivo, têm acarretado, entre tantos aspectos nefastos, um monumental desemprego, uma enorme precarização do trabalho e uma degradação crescente, na relação metabólica entre homem e natureza. (ANTUNES, 2000 p. 35). 
Na educação não foi diferente, com o crescimento do setor de serviços pôde-se perceber a transformação do papel da escola, incorporando a gestão administrativa verticalizada, a expansão do ensino básico, o aumento dos interesses de grandes grupos empresariais, a formação em massa sob a lógica neoliberal voltada para o mercado de trabalho, o abandono da educação pública, fazendo com que se ampliasse um ensino competitivo e desigual.

Para Ball (2014) o neoliberalismo combina diversas práticas organizadas em função da mercantilização de vários aspectos da vida. Faz isso não só através de projetos políticos e da doutrina econômica, mas também por meio das relações materiais e sociais com objetivo de criar outras oportunidades de obtenção de lucros. E com isso estimula o surgimento de: "novos tipos de atores sociais, sujeitos sociais híbridos que são espacialmente móveis, eticamente maleáveis e capazes de falar as linguagens do público, do valor privado e filantrópico" (BALL, 2014, p. 230).

$\mathrm{O}$ autor conta que a partir da implementação desta lógica, as políticas educacionais passaram a ser objeto de disputa, onde novos atores possuem papel central da venda de modelos educacionais a serem seguidos sob o discurso sedutor da educação como meio para desenvolvimento, qualificação e competitividade. Dentre eles temos os grandes organismos internacionais como OCDE, Banco Mundial, Unesco e outros, pesquisadores que prestam serviços à determinadas empresas, grupo de investidores e empresas (nacionais e internacionais), dentre outros. Assim, para ganhar espaço sustentam o argumento da crise na educação pública e aos poucos empurram a incorporação da lógica privada.

A partir deste discurso convincente da necessidade de solucionar os problemas educacionais, Ball (2014) conta que eles engendram formas de vender diferentes produtos para o setor educacional como gestão, formação de professores, novas tecnologias, programas, equipamentos, consultorias, livros, apostilas, muitas vezes sob a nomenclatura de sistemas de ensino. Ao mesmo tempo, influem nas políticas que envolvem o trabalho dos professores, seja por meio de avaliações externas (nacionais e internacionais), seja pelo controle de produtividade através de indicadores, por meio da formação, currículo, flexibilização legal, entre outros.

Diante desse contexto, a categoria dos professores encontrou barreiras que impediram seu pleno desenvolvimento como o enfraquecimento da categoria sindical, diluição dos empregos estáveis e estagnação dos salários. Ball descreve precisamente sobre isso: "As tecnologias neoliberais trabalham em nós para 
produzir um corpo docente e discente dócil e produtivo, e professores e alunos responsáveis e empreendedores" (BALL, 2014, p.66).

Uma das principais formas de precarização que atinge amplamente os professores brasileiros é a defasagem de salários que se trata de algo presente desde o início da profissão docente no Brasil. Todavia, como aponta o relatório publicado pelo Anuário Brasileiro da Educação Básica (2019), se compararmos a remuneração docente do início do século XX com os dias atuais perceberemos que a categoria vivenciou ao longo dos anos considerável mobilidade social ascendente. Isso se deu sobretudo na rede pública, como mostra o levantamento do documento nos últimos sete anos, com aumento salarial de 6,4\%. Entretanto, o mesmo documento também mostra que em comparação com o salário médio de profissionais das áreas de Exatas e Saúde a defasagem chega a 50\%. A situação se mostra mais grave quando se compara as disparidades entre as regiões brasileiras, onde alguns estados não possuem sequer um plano de carreira docente. No entanto, embora os salários se mostrem maiores do que outrora, esse aumento veio acompanhado de ampliação de carga horária pautada em brechas legais que permitem o acúmulo de cargos públicos, causando a sobrecarga de trabalho.

Para Santos (2012) esse processo de busca incessante pelo acúmulo do capital através do trabalho assalariado, ainda que iniciado nas fábricas e depois difundido para o setor de serviços, incluiu também mudanças socioespaciais como: urbanização, inovações tecnológicas, ampliação do comércio, criação de classes sociais, êxodo rural, explosão demográfica, novas formas de divisão do trabalho e alterações das relações sociais. Dois fenômenos passam a influenciar o cenário: de um lado, a globalização com a interferência dos organismos internacionais de financiamento impondo o neoliberalismo como condutor dos sistemas educacionais, a partir da redefinição do Estado, sob o argumento da inclusão e preparação para o mercado de trabalho, estabelecendo isso através de uma lógica de gestão empresarial. E de outro lado, mudanças externas ao ambiente escolar que impactam direta ou indiretamente o cotidiano dos protagonistas desse ambiente escolar.

Quando se trata da "nova organização laboral de ensino", cuidase de um processo de reestruturação produtiva assolado no sistema educacional brasileiro, marcado por uma forte ideologia de mercado, em que a função docente tornou-se uma mercadoria (GOMES \& BRITO, 2014, p.76) 
É nesse desenho contextual que o trabalho tornou-se flexível. Essa fluidez que parte do trabalho se propaga para outras questões da vida cotidiana como o deslocamento para trabalho. Ao pensarmos no espaço urbano percebemos que a circulação de bens, pessoas e ideias formam os movimentos que caracterizam a cidade, onde a mobilidade é parte integrante do processo de urbanização e sob a emergência da metropolização - processo que acentua a homogeneização do espaço, amplia sua fragmentação e torna os lugares hierarquizados e assim acaba por maximizar as desigualdades.

Portanto, se o espaço está submetido à ação do Estado, das empresas e das instituições supranacionais e esses mesmos organizam e definem o ritmo das cidades, pode-se dizer que a velocidade põe-se a serviço das políticas engendradas por tais agentes, ditando os padrões de deslocamento dos corpos (SANTOS, 2006), transformando esses fluxos no que Gaudemar (1979) denomina de mobilidade forçada ou mobilidade da força de trabalho. Vale esclarecer que o conceito de mobilidade a ser trabalhado aqui é o de mobilidade espacial pendular, descrito por Becker (2006) como deslocamentos intra-urbanos de caráter pendular, que são expressão do rearranjo no tecido urbano em função das mudanças no tecido social. Essa percepção difere da concepção neoclássica que pressupunha a mobilidade como sendo um ato decorrente exclusivamente das escolhas individuais. Nota-se que a questão é bem mais complexa quando percebemos uma estreita ligação entre o papel da mobilidade da força de trabalho e das mudanças no mundo de trabalho, em que eles se encontram submetidos cada vez mais à sujeição e são capturados pela alienação em seu cotidiano.

Desse modo, a mobilidade compreendida nessa dinâmica da velocidade é, portanto, um processo socioespacial no qual insere os indivíduos em uma lógica que favorece extração da mais-valia. Nesse sentido, ela funciona como uma qualidade essencial do capital e fundamental para compreendermos a produção do espaço.

Tal mobilidade da força de trabalho é comumente aceita no âmbito escolar, visto que em todos os segmentos da educação - educação infantil ao médio - convivem com este fenômeno em diferentes proporções. Embora tenha se tornado algo normalizado, os deslocamentos em grande proporção podem produzir problemas organizacionais e específicos ao trabalho docente, como a impossibilidade de consolidar trabalhos em equipe, baixo rendimento, desgaste físico e emocional, problemas de saúde, ausência de vínculo do professor com o ambiente escolar 
Tais deslocamentos não são uniformes, pois possuem perfis, seguem padrões, sazonalidades, particularidades sociais e espaciais, e até mesmo mostram a imobilidade em diversas situações, indivíduos que são privados de percorrer o espaço ou submetidos a situações degradantes. Estudos acerca desses padrões corroboram para embasamento das políticas públicas por mergulhar nas especificidades locais ou de cada categoria de trabalhadores. Porém, mais importante do que a aparência ou a forma do processo é a sua natureza; nesse sentido, faz-se necessário, para além do estudo técnico e somente empírico, uma discussão teórica acerca do que é essa mobilidade, dos processos que a ocasionam e que dela são ocasionados.

Em geral, as discussões sobre a temática relacionam o conceito de mobilidade à esfera de mudanças de categoria no trabalho, ou seja, mobilidade de funções, como a transferência entre escolas de uma mesma rede educacional ou entre redes de ensino diferentes, como a mudança entre as unidades escolares, exoneração e contratação de professores. Embora esse tipo de questão seja de grande relevância, pois também reflete a precarização da categoria, não é o objetivo desta pesquisa, mas sim o debate da mobilidade sob o viés da concepção espacial, os deslocamentos pendulares para o trabalho, que podem ou não ocasionar a mobilidade no trabalho, mudanças de funções, entre outras consequências.

A divisão social e territorial do trabalho encontra-se intrínseca à mobilidade. Esse movimento é histórico, o ato de movimentar-se é um dos elementos centrais para definição e construção dos indivíduos e das sociedades. A mobilidade, embora seja um conceito amplo, pode ser abordada em diferentes vertentes, desde a dimensão dos objetos que ampliam esse deslocamento como transportes, ou através da dimensão das técnicas, das políticas de acesso, dos fluxos de mercadorias, pessoas e serviços, em todas imprime a ideia de movimento. Como afirma Balbim:

$\mathrm{O}$ conceito de mobilidade adquire formas e presta-se a usos e explicações diversas. Da mobilidade cotidiana, passa-se às mobilidades social, residencial e do trabalho, ou, mais recentemente, à mobilidade simbólica. Também são formas de mobilidade as migrações - bem como a mobilidade pendular, do turismo e do lazer -, até chegar-se ao nomadismo ou ao imobilismo. (BALBIM, (2016, p.23)

Portanto, diante da polissemia do conceito, a abordagem utilizada será a de mobilidade pendular do cotidiano. O deslocamento é o movimento, a mobilidade é mais abrangente, porque ela engloba não só o movimento, mas também os 
processos que a ocasionam, a percepção dos indivíduos e vida que é modelada a partir desses fluxos.

Para tanto, o recorte escolhido foi a microrregião metropolitana do estado do Rio de Janeiro por tratar-se de uma área que engloba grandes fluxos populacionais, e, como a questão da mobilidade ultrapassa a escala municipal, havia a necessidade de buscar uma área maior que os limites político-administrativos locais e que fosse condizente com os estudos de deslocamento. Além disso, o estado do Rio possui a quarta maior rede de ensino do país com 11.325 escolas, somente atrás dos estados de São Paulo, Minas Gerais e Bahia. Possui 3.558.698 matrículas, sendo 2.453.953 $(68,9 \%)$ na rede pública e 1.104 .745 (31\%) na rede privada e 158.398 docentes na educação básica. A microrregião do estado abarca a segunda maior densidade populacional e dela fazem parte 16 municípios, comportando a maior parte dos professores e escolas do estado.

Desse modo, foi escolhida a microrregião por apresentar-se como uma mancha urbana homogênea e contínua e que seria suficiente para representar a questão tratada no trabalho, sem necessitar abrir o estudo para a esfera da região metropolitana como um todo. Vale ressaltar que, embora a pesquisa utilize esta região como recorte empírico, a questão abordada aqui não é uma realidade exclusiva do Rio de Janeiro, pelo contrário, também é reproduzida em maior ou menor grau em outras regiões metropolitanas do país.

Assim, foi utilizado o parâmetro de arranjos espaciais para a definição desta escala, pois constitui um quadro de referência da urbanização no país (IBGE, 2016). A conurbação é uma forma de identificar estes arranjos. Ela permite ver estes limites extravasados que estabelecem entre si fortes vínculos socioeconômicos. O IBGE utiliza a identificação dos arranjos populacionais para definir as médias e grandes concentrações urbanas, por meio de cortes populacionais.

Em 2016, o IBGE delimitou 26 grandes concentrações urbanas no país, formadas, em sua maioria, por arranjos populacionais com população acima de 750000 habitantes. Já a microrregião trata-se de uma subdivisão da região metropolitana, ela é uma delimitação territorial recente, foi definida a partir das diretrizes da Política Nacional de Mobilidade Urbana (Lei Federal n ${ }^{\circ}$ 12.587/2012) e do Estatuto da Metrópole (Lei $\mathrm{n}^{\mathrm{o}}$ 13.089/2015), que tratam da criação das regiões metropolitanas, aglomerações urbanas e microrregiões. 
Segundo o IBGE (2016), a existência desses arranjos é fruto da globalização que ao mesmo tempo conecta e fragmenta o território. A globalização acentua e concentra o dinamismo através da articulação das empresas, das redes de transporte e comunicação que conectam os lugares e da centralidade do capital financeiro que amplia o setor de serviços (IBGE, 2016). Este dinamismo não só tem origem nos investimentos e nas decisões de mercado, como nos locais de destino dos fluxos de diversas naturezas. As maiores cidades globais funcionam como peça-chave na globalização, pois impulsionam as redes de fluxos globais.

No âmbito geográfico, significa uma nova ordem mundial que se caracteriza pelo "entrelaçamento" entre escalas territoriais ou a ampliação da interligação de centros urbanos em uma nova divisão do trabalho, que reorganiza o trabalho e as atividades econômicas, os mercados e as relações de governança em múltiplas escalas e que produz distintos arranjos populacionais. (IBGE, 2016, p.12)

Nesse sentido, estes arranjos pautados nesta base econômica acrescentaram novos elementos ao território, como trabalhadores qualificados e atributos tecnológicos, que possuem grande importância ao avanço do setor terciário, ocasionando uma fragmentação crescente entre local de moradia e local de trabalho e assim ampliando a mobilidade populacional, ao mesmo tempo que mantém e aprofunda as desigualdades do país.

Logo, pode-se dizer que os processos sociais e econômicos que definem espaços urbanos coesos surgem da combinação da mobilidade para o trabalho e estudo e do espaço construído com a expansão das construções (JULIEN, 2000 apud IBGE, 2016). Assim, os movimentos pendulares são fundamentais na dinâmica urbana. Eles nos ajudam a compreender a organização funcional das regiões metropolitanas, mostram a dimensão e caracterizam os fluxos para trabalho e estudos, permitem a realização do planejamento urbano mais eficaz tanto na questão de transportes quanto do trabalho. Desse modo, esse espaço urbano mercantilizado que se constituiu em torno na lógica econômica também mercantiliza a vida das pessoas que nele habitam e transitam.

Assim, ao pensarmos no trabalho e na mobilidade é necessário entendê-los a partir de uma lógica multidimensional. Nesse sentido, embora os modelos de produção tentem explicar o meio pelo qual o trabalho é destituído de valor e sentido, eles não conseguem responder à totalidade e às dimensões peculiares das práticas cotidianas, pois estas impõem diversas variáveis aos sistemas. 
Ao investigar rapidamente o tema precarização do trabalho docente não foi difícil encontrar inúmeras pesquisas que se debruçam sobre a questão salarial, a falta de autonomia, o controle por meio de avaliações externas, a dimensão de exaustão física, a sobrecarga, entre outras questões relevantes, mas uma pergunta se colocava a todo instante: a mobilidade não teria impacto na precarização do trabalho? Já que se trata de algo tão presente no cotidiano de boa parte dos profissionais.

Portanto, a necessidade de se compreender os fatores que impactam direta e indiretamente no trabalho destes docentes - como a fragmentação de carga horária e o processo de desvalorização salarial, que leva a sobrecarga de trabalho e por conseguinte à constante mobilidade - mostra-se como estudo relevante para o levantamento de problemáticas relacionadas ao campo educacional. Tais fatores se tornam necessários para colaborar com o aprimoramento de políticas públicas e ao mesmo tempo desafiador devido à dimensão do problema que emerge do processo produtivo atual.

Como aponta Tardif e Lessard (2009, p.38), os professores não são apenas agentes que executam ordens na escola, mas também atores, pois agem sobre ela, interagem com toda comunidade escolar. É preciso conhecer a docência em sua totalidade e multiplicidade de sentidos que vão desde o espaço escolar organizado à subjetividade das atividades humanas. Desse modo, os processos que influem em seu cotidiano refletem em sua função como experiência pessoal. A mobilidade é apenas um dos aspectos que se encontra presente na vida destes indivíduos que pode ser opressora ou não, mas é ontológica, assim como trabalho.

Nesse sentido, esta pesquisa visa contribuir não só para o campo da pesquisa educacional, mas também para a Geografia, uma vez que se apropria do método geográfico para compreensão espacial da análise dos deslocamentos diários, visando a um estudo crítico que contribua para se pensar nas melhorias do ensino, bem como na valorização de seus profissionais no país.

Por fim, a pesquisa foi dividida em três capítulos: no primeiro, pretende-se fazer uma discussão sobre o sentido do trabalho e a intensificação da precarização. No segundo capítulo, discutiremos o conceito de mobilidade e sua relação com o trabalho. No terceiro capítulo, pretende-se estabelecer a relação entre esses conceitos, abordando um panorama da profissão docente no recorte espacial escolhido, através de dados oficiais e da regulamentação legal da categoria, e de 
uma análise sobre a mobilidade dos professores na microregião metropolitana do Rio de Janeiro e aplicação de questionários aos professores.

\subsection{Objeto e objetivos}

Objeto:

- A mobilidade docente como parte do processo de precarização do trabalho.

Objetivo geral:

- Analisar a mobilidade dos professores na Região Metropolitana e discuti-la como um agravante à precarização do professor.

Objetivos específicos:

- Discutir o que se entende por precarização e de que modo os professores se inserem nesse processo.

- Investigar que processos e ações contribuíram para ampliação dos fluxos de deslocamento e precarização.

- Compreender as condições de trabalho do professor na Microrregião Metropolitana do Rio de Janeiro e como isto relaciona-se à mobilidade.

- Mapear e analisar as dinâmicas de deslocamento dos professores na Região Metropolitana do Rio de Janeiro.

\subsection{Questionamentos e hipóteses}

As mudanças laborais relacionadas à reestruturação econômica ocorrida nas últimas décadas se inseriram no sistema educacional brasileiro sob a forma de flexibilização do trabalho docente. Para alguns estratos da classe trabalhadora essa condição de mobilidade é maior do que para outros, além disso, dentro dessa categoria há diferentes graus de respostas à precarização e à mobilidade, portanto, surge uma questão: como podemos mostrar onde estes problemas são maiores na categoria docente? Portanto, como questão central pretende-se investigar de que modo a mobilidade espacial docente relaciona-se com a precarização do trabalho?

A partir disso, outras indagações surgiram de modo coadjuvante à questão central visando guiar a pesquisa, tais como:

- Quais mudanças têm assolado o mundo do trabalho? O que se entende por precarização do trabalho docente? Quais leis contribuíram para esse processo? 
- Qual tipo de mobilidade se enquadra os fluxos destes professores? Por que a mobilidade endossa o processo de precarização? Seria a mobilidade uma necessidade ou uma escolha?

- Qual o panorama do trabalho docente atualmente (salário, jornadas de trabalho, atribuições, concursos públicos, políticas públicas)? Como se comporta a distribuição de professores na Região Metropolitana do Rio de Janeiro? Qual perfil docente se relaciona com maior ou menor intensidade dos fluxos pendulares interescolas?

- Como os professores percebem esses deslocamentos? A mobilidade interescolas influencia na mudança de local de moradia ou permuta?

\subsection{Procedimentos metodológicos}

A pesquisa se desenha pautando-se na esfera macro estrutural que envolve a discussão teórica sobre a gênese deste processo, dados sobre estes trabalhadores e as políticas (leis, decretos, ações, contexto). Porém, para entender a mobilidade foi necessário adentrar minimamente na esfera micro, ou seja, do cotidiano, indagando os professores acerca da percepção dessa rotina mecânica, organizada, previsível, programada na qual estão submetidos diariamente. Deste modo, a metodologia foi dividida em quatro etapas:

- Aporte bibliográfico acerca dos temas precarização docente e mobilidade.

- Levantamento de informações e dos indicadores apontados anteriormente.

- Tratamento dos microdados do Censo Escolar e mapeamento dos principais fluxos, tempo gasto, perfil e comparando os diferentes sistemas de ensino privado, municipal, estadual e federal.

- Aplicação de questionário online de amostragem aos professores do ensino básico com a finalidade de levantamento qualitativo a respeito das condições de trabalho, impactos no trabalho, deslocamento dos professores.

Sendo assim, buscou-se combinar metodologias qualitativas e quantitativas através da seleção de alguns indicadores de precarização, de mobilidade e outros complementares que ajudaram na compreensão desse sistema interdependente entre trabalho e deslocamento. Para isto utilizou-se a compilação de diferentes fontes com a finalidade de fazer um panorama da situação atual dos professores e evidenciar a questão central da pesquisa. O quadro 1 a seguir descreve os indicadores escolhidos e suas respectivas fonte de dados separados por capítulo. 


\begin{tabular}{|c|c|c|c|c|c|}
\hline \multicolumn{6}{|c|}{ Capítulo 1} \\
\hline \multicolumn{2}{|c|}{$\begin{array}{l}\text { Indicadores de trabalho e } \\
\text { precarização }\end{array}$} & Fonte & \multicolumn{2}{|c|}{ Indicadores complementares } & Fonte \\
\hline \multicolumn{2}{|c|}{ Valorização docente } & $\begin{array}{l}\text { ABEB }(2018) \text { e } \\
\text { Talis }(2018)\end{array}$ & \multicolumn{2}{|c|}{$\begin{array}{c}\text { Orçamento público para } \\
\text { educação }\end{array}$} & $\begin{array}{l}\text { Portal } \\
\text { Transparência, } \\
\text { EAG (2020) }\end{array}$ \\
\hline \multicolumn{2}{|c|}{ Legislação trabalhista } & $\begin{array}{l}\text { CF, PNE, TST, } \\
\text { Congresso e } \\
\text { Senado. }\end{array}$ & \multicolumn{2}{|c|}{ Fechamento de escolas } & $\begin{array}{l}\text { SILVA (2019) } \\
\text { e ALERJ } \\
(2020)\end{array}$ \\
\hline \multicolumn{2}{|c|}{$\begin{array}{c}\text { Salário (comparação com } \\
\text { outras carreiras e em nível } \\
\text { nacional) }\end{array}$} & $\begin{array}{l}\text { ABEB (2018), } \\
\text { EAG - OCDE } \\
\quad(2018\end{array}$ & \multicolumn{2}{|c|}{$\begin{array}{l}\text { Proporção de alunos por } \\
\text { professor }\end{array}$} & $\begin{array}{l}\text { EAG - OCDE } \\
(2018)\end{array}$ \\
\hline \multicolumn{6}{|c|}{ Capítulo 2} \\
\hline \multicolumn{2}{|c|}{ Indicadores de mobilidade } & Fonte & \multicolumn{2}{|c|}{ Indicadores complementares } & Fonte \\
\hline \multicolumn{2}{|c|}{$\begin{array}{c}\text { Deslocamento para o trabalho } \\
\text { na MMRJ (tempo de } \\
\text { deslocamento, local de } \\
\text { exercício, carga horária de } \\
\text { trabalho, renda, ocupação) }\end{array}$} & $\begin{array}{l}\text { PNAD - Censo } \\
2010\end{array}$ & \multicolumn{2}{|c|}{$\begin{array}{l}\text { Melhores e piores índices de } \\
\text { deslocamentos pendulares - } \\
\text { internacional }\end{array}$} & $\begin{array}{l}\text { ExpertMarket } \\
(2019)\end{array}$ \\
\hline \multicolumn{6}{|c|}{ Capítulo 3} \\
\hline $\begin{array}{l}\text { Indicadores de } \\
\text { trabalho e } \\
\text { precarização }\end{array}$ & Fonte & $\begin{array}{l}\text { Indicadores de } \\
\text { mobilidade }\end{array}$ & Fonte & $\begin{array}{l}\text { Indicadores } \\
\text { complement } \\
\text { ares }\end{array}$ & Fonte \\
\hline $\begin{array}{l}\text { Salário } \\
\text { (evolução } \\
\text { salarial, } \\
\text { crescimento } \\
\text { salarial X } \\
\text { inflação }\end{array}$ & $\begin{array}{l}\text { INCP- IBGE } \\
(2010- \\
2019) \\
\text { RAIS- MTE } \\
(2010- \\
2019)\end{array}$ & $\begin{array}{l}\text { Deslocamento } \\
\text { pendular } \\
\text { docente } \\
\text { intrametropolit } \\
\text { ano (casa- } \\
\text { trabalho e } \\
\text { interescolas) }\end{array}$ & $\begin{array}{l}\text { Microdados } \\
\text { Censo Escolar } \\
\text { (2018) }\end{array}$ & $\begin{array}{c}\text { Perfil } \\
\text { docente }\end{array}$ & $\begin{array}{c}\text { Resumo } \\
\text { Técnico } \\
\text { Censo } \\
\text { Escolar } \\
\text { (2018) e } \\
\text { Microdados } \\
\text { Censo } \\
\text { Escolar } \\
(2018)\end{array}$ \\
\hline \multirow{3}{*}{$\begin{array}{c}\text { Situação } \\
\text { trabalhista } \\
\text { (regime de } \\
\text { contratação, } \\
\text { admissão e } \\
\text { demissão, } \\
\text { trabalho } \\
\text { parcial) }\end{array}$} & \multirow{3}{*}{$\begin{array}{l}\text { PNAD-IBGE } \\
(2020), \\
\text { RAIS, } \\
\text { CAGED - } \\
\text { MTE (2019) } \\
\text { e Censo } \\
\text { Escolar } \\
(2018)\end{array}$} & $\begin{array}{l}\text { Distribuição } \\
\text { Docente e } \\
\text { quantidade de } \\
\text { escolas que } \\
\text { atua }\end{array}$ & $\begin{array}{l}\text { ABEB (2018) e } \\
\text { Microdados } \\
\text { Censo Escolar } \\
(2018)\end{array}$ & $\begin{array}{l}\text { Indicador de } \\
\text { Esforço } \\
\text { Docente }\end{array}$ & $\begin{array}{l}\text { Saeb - } \\
\text { Painel } \\
\text { educaciona } \\
\text { I (2018) }\end{array}$ \\
\hline & & $\begin{array}{c}\text { Tempo e } \\
\text { distância de } \\
\text { deslocamento } \\
\text { dos } \\
\text { professores }\end{array}$ & $\begin{array}{l}\text { Autoria própria } \\
\text { (questionário e } \\
\text { média do Censo } \\
\text { Escolar - 2018) }\end{array}$ & \multirow[t]{2}{*}{$\begin{array}{l}\text { Matrículas e } \\
\text { Docentes }\end{array}$} & \multirow[t]{2}{*}{$\begin{array}{l}\text { Sinopse } \\
\text { Estatística } \\
\text { do Censo } \\
\text { Escolar } \\
(2010- \\
2019)\end{array}$} \\
\hline & & $\begin{array}{l}\text { Impacto da } \\
\text { mobilidade na } \\
\text { vida dos } \\
\text { docentes }\end{array}$ & $\begin{array}{l}\text { Autoria própria } \\
\text { (questionário) }\end{array}$ & & \\
\hline
\end{tabular}

Quadro 1: indicadores e fontes utilizados na pesquisa. Fonte: própria. 
No capítulo 1, além da discussão teórica sobre o trabalho utilizou-se como fonte de dados pesquisas internacionais sobre a educação elaboradas pela OCDE como a Talis e a Education at a Glance (EAG), ambas de 2018, disponibilizadas pelo INEP que estabelecem uma comparação entre os países onde a pesquisa foi feita. A primeira abordando a valorização do trabalho docente e a segunda a proporção de alunos por turma. Além disso, neste capítulo utilizou-se os dados do ABEB (2018) para caracterizar a valorização do ponto de vista nacional estabelecendo um comparativo salarial com outras carreiras de nível superior.

Também foi levantado neste capítulo (tópico 2.3) as leis que regulam o trabalho docente e a educação, cujo recorte temporal legal se deu a partir da Constituição Federal de 1988. Além disso, para entender a questão orçamentária da educação que interfere diretamente nos salários utilizou-se os dados oferecidos pelo Portal Transparência (BRASIL, 2020) do Governo Federal e alguns autores, a partir disso foi possível compreender minimamente como funciona os repasses na educação entre a União, os estados e os municípios e a evolução do orçamento da educação ao longo dos anos.

Neste tópico também foi abordado uma relação das leis com as políticas atuais que aprofundam o problema como a expansão de novas formas de contratação e o fechamento de escolas que agravam tanto o deslocamento quanto o trabalho. O segundo capítulo aborda um breve arsenal teórico conceitual sobre a mobilidade e pauta-se nas diferenciações dos tipos de mobilidade dialogando com a Geografia ao tratar os fluxos no espaço. É importante frisar que a princípio o recorte espacial seria toda a região metropolitana, porém constatou-se que o recorte na microrregião seria o ideal para responder às questões propostas, pois trata-se de um meio termo entre a escala municipal e a metrópole, pois recortar localmente tornaria difícil falar do deslocamento desta categoria e para tratar de toda a região metropolitana seria necessário mais tempo de pesquisa.

São 16 municípios na microrregião e 21 na região metropolitana ${ }^{1}$, a primeira possui uma mancha urbana contínua, mostra maior integração entre os municípios vizinhos, a qual fazem parte os municípios de Belford Roxo, Duque de Caxias, Guapimirim, Itaboraí, Japeri, Magé, Maricá, Mesquita, Nilópolis, Niterói, Nova

\footnotetext{
${ }^{1}$ Em 2019 o município de Petrópolis, situado na Região Serrana do Rio de Janeiro, foi incorporado à Região Metropolitana do Rio de Janeiro. Porém, escolhemos trabalhar com o recorte espacial do IBGE anterior a essa nova classificação.
} 
Iguaçu, Queimados, Rio de Janeiro, São Gonçalo, São João de Meriti e Tanguá. Já a segunda possui outros cinco municípios a mais e que são descontínuos, Rio Bonito, Cachoeiras de Macacu, Itaboraí, Seropédica e Itaguaí. Como podemos ver no mapa 1 abaixo elaborado pelo IBGE para classificar as áreas de arranjos espaciais.

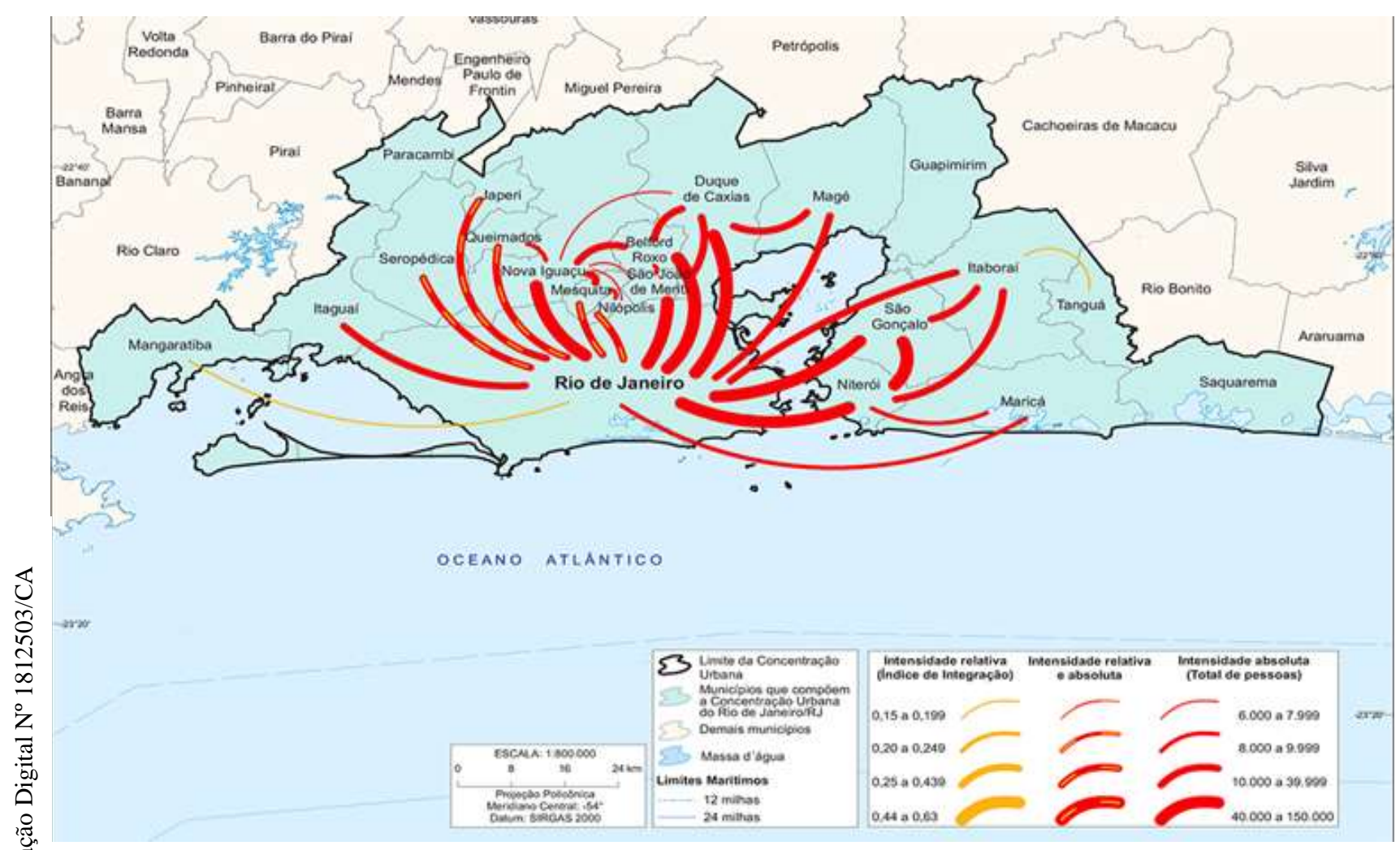

Mapa 1: mapa de intensidade dos deslocamentos para trabalho e estudo na Concentração Urbana do Rio de Janeiro/RJ. Fonte: IBGE (2016, p. 153)

O mapa ilustra às áreas de maior integração mediante o fluxo de pessoas para trabalho e estudo. Pode-se observar que há outros municípios no arranjo que não fazem parte da RMRJ e que possuem integração, como Mangaratiba. Já outros que se situam na RMRJ possuem baixa integração como Paracambi e Guapimirim. No entanto, com exceção do município de Guapimirim que faz parte tanto da RMRJ quanto da MMRJ, todos os outros municípios da microrregião possuem grande integração entre si. Portanto, o recorte espacial seria suficiente para explicar os fluxos dos professores.

Nesta parte foi utilizado como fonte de dados amostrais o Censo $2010^{2}$ que levantou informações sobre o deslocamento para trabalho e estudo nas cidades e regiões

\footnotetext{
${ }^{2}$ Este é o único órgão que realiza levantamento público e abrangente sobre o deslocamento de trabalhadores nas cidades brasileiras. A pesquisa mais recente foi esta realizada em 2010, por isso o recorte temporal destoa dos demais período utilizados aqui, ou seja, 2018 e 2019.
} 
metropolitanas brasileiras. Para isso foram selecionadas algumas variáveis na plataforma SIDRA:

\begin{tabular}{|c|c|c|}
\hline Nível Territorial & \multicolumn{2}{|l|}{ Microrregião Geográfica } \\
\hline Unidade Territorial & \multicolumn{2}{|l|}{33018 - Rio de Janeiro (RJ) } \\
\hline Pesquisa & \multicolumn{2}{|c|}{$\begin{array}{l}\text { Censo Demográfico/ Censo Demográfico 2010/ Resultado da amostra - } \\
\text { Educação e deslocamento }\end{array}$} \\
\hline Assunto & \multicolumn{2}{|l|}{ Deslocamento } \\
\hline Ano & \multicolumn{2}{|l|}{2010} \\
\hline $\begin{array}{l}\text { Variáveis } \\
\text { aplicáveis a todas } \\
\text { as tabelas: }\end{array}$ & \multicolumn{2}{|c|}{$\begin{array}{l}\text { Pessoas de } 10 \text { anos ou mais de idade, ocupadas na semana de referência } \\
\text { (Pessoas): } 0 \text { a } 8 \text { casas decimais (tabelas } 3602 \text { e } 3603 \text { ) } \\
\text { Pessoas de } 10 \text { anos ou mais de idade, ocupadas na semana de referência: } \\
\text { percentual do total geral (\%) - } 2 \text { a } 5 \text { casas decimais (tabela } 3604 \text { ) } \\
\text { sexo, cor, raça, grupo de idade - Total } \\
\text { Local de exercício do trabalho principal: Município de residência, Outro } \\
\text { município, Mais de um município (tabelas } 3602 \text { e 3603) }\end{array}$} \\
\hline \multirow[t]{3}{*}{ Tabela de dados } & $\begin{array}{l}3602 \text { - Pessoas de } 10 \text { anos ou } \\
\text { mais de idade, ocupadas na } \\
\text { semana de referência, por local de } \\
\text { exercício do trabalho principal e } \\
\text { sexo, segundo a cor ou raça, o } \\
\text { nível de instrução, os grupos de } \\
\text { idade e a seção de atividade do } \\
\text { trabalho principal }\end{array}$ & $\begin{array}{l}\text { Instrução: Superior completo } \\
\text { Seção de atividade do trabalho } \\
\text { principal: Educação } \\
\text { Local de exercício do trabalho } \\
\text { principal: outro município: Municípios } \\
\text { da região metropolitana (mapa) }\end{array}$ \\
\hline & $\begin{array}{l}3603 \text { - Pessoas de } 10 \text { anos ou } \\
\text { mais de idade, residentes em } \\
\text { domicílios particulares, ocupadas } \\
\text { na semana de referência, } \\
\text { exclusive as pessoas cuja } \\
\text { condição no domicílio era } \\
\text { pensionista, empregado(a) } \\
\text { doméstico(a) ou seu parente, por } \\
\text { local de exercício do trabalho } \\
\text { principal, segundo a situação do } \\
\text { domicílio e as classes de } \\
\text { rendimento nominal mensal } \\
\text { domiciliar per capita }\end{array}$ & $\begin{array}{l}\text { Classes de rendimento nominal } \\
\text { mensal domiciliar per capita: } \\
\text { Até } 1 / 4 \text { de salário mínimo } \\
\text { Mais de } 1 / 4 \text { a } 1 / 2 \text { salário mínimo } \\
\text { Mais de } 1 / 2 \text { a } 1 \text { salário mínimo } \\
\text { Mais de } 1 \text { a } 2 \text { salários mínimos } \\
\text { Mais de } 2 \text { a } 3 \text { salários mínimos } \\
\text { Mais de } 3 \text { a } 5 \text { salários mínimos } \\
\text { Mais de } 5 \text { salários mínimos }\end{array}$ \\
\hline & $\begin{array}{l}3604 \text { - Pessoas de } 10 \text { anos ou } \\
\text { mais de idade, ocupadas na } \\
\text { semana de referência, que, no } \\
\text { trabalho principal, trabalhavam } \\
\text { fora do domicílio e retornavam } \\
\text { diariamente do trabalho para o } \\
\text { domicílio, exclusive as pessoas } \\
\text { que, no trabalho principal, } \\
\text { trabalhavam em mais de um } \\
\text { município ou país, por tempo } \\
\text { habitual de deslocamento do } \\
\text { domicílio para o trabalho principal, } \\
\text { segundo a situação do domicílio e } \\
\text { os grupos de horas habitualmente } \\
\text { trabalhadas por semana no } \\
\text { trabalho principal }\end{array}$ & $\begin{array}{l}\text { Tempo habitual de deslocamento do } \\
\text { domicílio para o trabalho principal: } \\
\text { Até cinco minutos } \\
\text { De seis minutos até meia hora } \\
\text { Mais de meia hora até uma hora } \\
\text { Mais de uma hora até duas horas } \\
\text { Mais de duas horas } \\
\text { Grupo de horas trabalhadas por } \\
\text { semana no trabalho principal: } \\
\text { Até } 14 \text { horas } \\
15 \text { a } 29 \text { horas } \\
30 \text { a } 39 \text { horas } \\
40 \text { a } 44 \text { horas } \\
45 \text { a } 48 \text { horas } \\
49 \text { horas ou mais }\end{array}$ \\
\hline
\end{tabular}

Quadro 2: Variáveis de deslocamento selecionadas na plataforma SIDRA/IBGE. Fonte: própria. 
A partir desta seleção pôde-se obter informações sobre o deslocamento de trabalhadores em geral e de profissionais da área de ensino na MMRJ com o objetivo de caracterizar estes movimentos nesta microrregião. Além disso, complementamos a discussão situando a mobilidade fluminense em relação à cidades de outros países utilizando como fonte um estudo realizado pela empresa inglesa de consultoria ExpertMarket, que realizou um estudo através do aplicativo Moovit que fornece informações sobre o transporte público e levou em conta o tempo médio gasto no deslocamento diário, o tempo médio de espera por um ônibus ou trem a cada dia, a distância média da viagem (só ida), a porcentagem de passageiros que fazem pelo menos uma alteração em uma única viagem, dados do custo de vida para calcular o custo médio de um cartão de viagem mensal em cima do salário líquido médio mensal, além de informações retiradas do INRIX 2017 Global Traffic Scorecard para encontrar o número médio de horas gastas em congestionamentos em 240 dias de deslocamento.

O terceiro capítulo analisa apenas a situação dos professores na MMRJ fazendo um panorama da questão salarial, trabalhista, do perfil docente e da mobilidade. $\mathrm{Na}$ primeira parte do capítulo (tópico 4.1) levantamos o perfil docente por gênero, idade e vínculos utilizando o resumo técnico do Censo Escolar (2018). Além da evolução de matrículas e do número de professores na MMRJ ao longo da última década extraídas da Sinopse Estatística do Censo Escolar (BRASIL 2010 a 2019).

Nesse tópico objetiva-se compreender as condições de trabalho destes professores. Assim, foi apresentado o indicador de esforço docente elaborado pelo Saeb disponibilizado em sua plataforma digital chamada Painel Educacional (BRASIL, 2019).

O Painel Educacional divide os dados em três categorias: trajetória, contexto e aprendizagem, além disso, organiza as informações de acordo com as redes de ensino (municipal e estadual). Nele temos os dados somados da educação infantil ao médio, comparando a média total dos professores que atuam nas redes municipais do estado (RME) e aqueles que trabalham na rede estadual por município (REM). Assim, cada rede municipal isolada recebe a nomenclatura de RM e a rede estadual de cada município chama-se RE. 
Painel Educacional Municipal - dados da Rede Municipal (RM) e da Rede Estadual do Município (REM).

Painel Educacional Estadual - dados da Rede Estadual (RE) e Rede Municipal do Estado (RME).

Quadro 3: Nomenclaturas do indicador de esforço docente. Fonte: Inep/Painel Educacional.

O indicador busca sintetizar aspectos do trabalho do professor que endossam a sobrecarga na função. Para isso, levam em consideração as informações os turnos de trabalho, as escolas e as etapas de atuação. Utilizam uma classificação dividida por níveis, como podemos ver no quadro 4:

\begin{tabular}{|c|l|}
\hline Níveis & \multicolumn{1}{c|}{ Descrição } \\
\hline Nível 1 & Docente que tem até 25 estudantes e atua em um único turno, escola e etapa. \\
\hline Nível 2 & Docente que tem entre 25 e 150 estudantes e atua em único turno, escola e etapa. \\
\hline Nível 3 & $\begin{array}{l}\text { Docente que tem entre } 25 \text { e } 300 \text { estudantes e atua em um ou dois turnos em uma } \\
\text { única escola e etapa. }\end{array}$ \\
\hline Nível 4 & $\begin{array}{l}\text { Docente que tem entre } 50 \text { e } 400 \text { estudantes e atua em dois turnos, em uma ou duas } \\
\text { escolas e em duas etapas. }\end{array}$ \\
\hline Nível 5 & $\begin{array}{l}\text { Docente que tem mais de } 300 \text { estudantes e atua nos três turnos, em duas ou três } \\
\text { escolas e em duas ou três etapas. }\end{array}$ \\
\hline Nível 6 & $\begin{array}{l}\text { Docente que tem mais de } 400 \text { estudantes e atua nos três turnos, em duas ou três } \\
\text { escolas e em duas ou três etapas. }\end{array}$ \\
\hline
\end{tabular}

Quadro 4: Indicadores de esforço docente. Dados: SAEB. Fonte: Painel educacional (2019)

Desse modo, para se ter uma visão geral dos três segmentos da educação básica, escolheu-se comparar a média da Rede Estadual e das Rede Municipais do estado do Rio de Janeiro ${ }^{3}$. Para tanto, optou-se por comparar as escolas estaduais (RE) e as escolas municipais do estado do Rio (RME). Observando os dados do nível fundamental (séries iniciais e séries finais) pôde-se constatar uma considerável discrepância em relação ao número de alunos por professor, turnos e turmas, chegando a dobrar em relação ao nível 3, por exemplo, referente aos professores com até 300 alunos atuando em dois turnos, porém ainda em uma única escola.

\footnotetext{
3 Como a plataforma não possuía o recorte por microrregião, apenas estados e municípios, levantamos primeiramente os resultados do estado do Rio de Janeiro e depois por município da região metropolitana.
} 


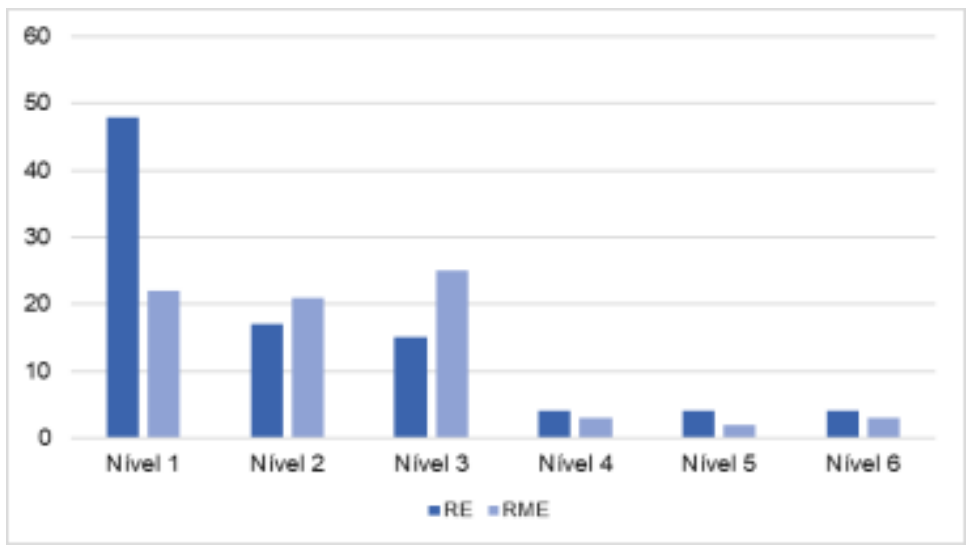

Gráfico 1: indicador de esforço docente estado do Rio de Janeiro - anos iniciais (em porcentagem). Fonte: Saeb/ Painel Educacional. (2019)

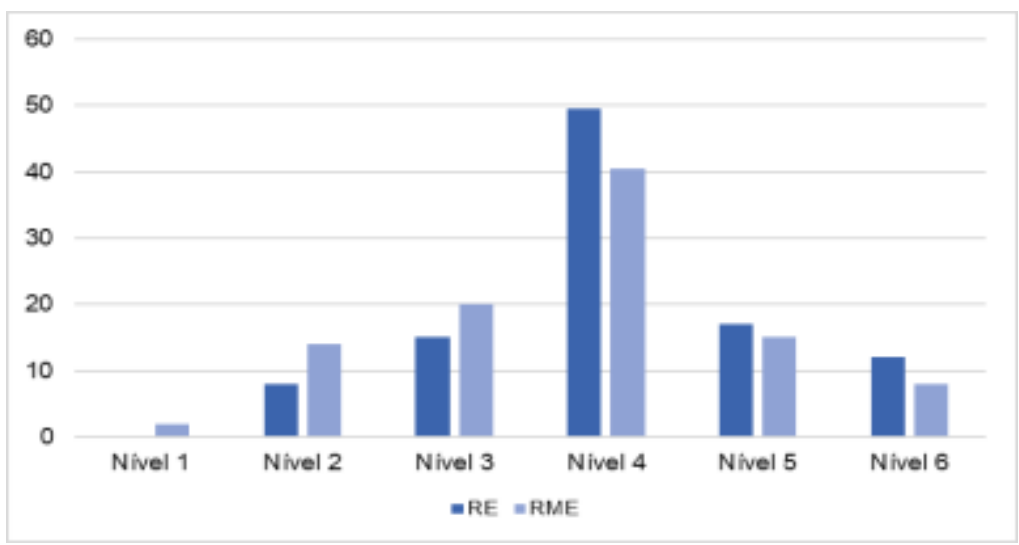

Gráfico 2: indicador de esforço docente estado do Rio de Janeiro - anos finais. Fonte: Saeb/ Painel Educacional (2019)

Quando comparado ao ensino médio o número de alunos por professor torna-se maior, a quantidade de turmas, turnos e escolas também aumenta. Como mostra o gráfico a seguir.

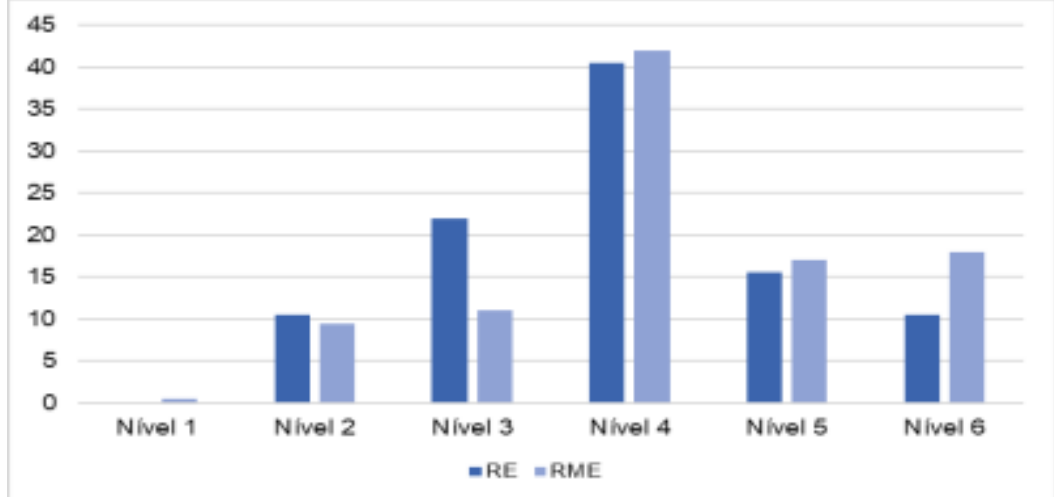

Gráfico 3: indicador de esforço docente estado do Rio de Janeiro - ensino médio. Fonte: Saeb/ Painel Educacional (2019).

Assim, percebemos que aqueles que possuem mais vínculos e trabalhavam mais horas são os que atuam nos anos finais do ensino fundamental e no ensino médio. 
Este foi um indicador fundamental para traçar a metodologia e filtrar a amostragem nos microdados que foram usados na etapa seguinte (tópico 4.2), dos deslocamentos docentes, pois a partir dele escolheu-se averiguar o deslocamento dos professores que trabalham nestes segmentos, descartando os docentes do ensino fundamental anos iniciais. Além disso, no tópico 4.2 buscou-se analisar este indicador de esforço docente comparando os municípios da MMRJ utilizando os microdados do Saeb (BRASIL, 2018).

Ainda neste tópico, foi feito uma análise da evolução salarial dos docentes da MMRJ ao longo da última década, segundo dados disponíveis pelo Ministério do Trabalho e Renda (MTE) através da RAIS e comparou-se à inflação medida pelo INPC-IBGE. Além do levantamento de professores em regime parcial ao longo desta última década. Neste item foram extraídas as seguintes variáveis das plataformas do MTE e do IBGE:

\begin{tabular}{|c|c|c|c|}
\hline \multicolumn{4}{|c|}{ RAIS - MTE } \\
\hline \multirow[t]{2}{*}{ Tabelas } & RAIS vínculo id & Conteúdo & $\begin{array}{c}\text { V|Remuneração Média } \\
\text { Nominal e Indicador de } \\
\text { trabalho parcial }\end{array}$ \\
\hline & Ano corrente a 2020 & Ano & 2010 a 2019 \\
\hline \multirow[t]{2}{*}{ Estrutura } & Vínculo ativo 31/12 - SIM & $\begin{array}{c}\text { Seleção por } \\
\text { assunto: Geográfico }\end{array}$ & $\begin{array}{l}\text { Microrregião - Rio de } \\
\text { Janeiro }\end{array}$ \\
\hline & $\begin{array}{l}\text { Natureza Jurídica Especial } \\
\text { (pública, privada, federal, } \\
\text { estadual, municipal) }\end{array}$ & $\begin{array}{l}\text { Seleção por } \\
\text { assunto: } \\
\text { CBO - } 2002 \text { - } \\
\text { Subgrupo }\end{array}$ & $\begin{array}{l}\text { Professores de nível } \\
\text { superior na educação } \\
\text { infantil e no ensino } \\
\text { fundamental } \\
\text { Professores de E.M. }\end{array}$ \\
\hline \multicolumn{4}{|c|}{ INPC-IBGE } \\
\hline Série histórica & Brasil & dezembro & $2009^{5}-2019$ \\
\hline
\end{tabular}

Quadro 5: variáveis para levantamento da média remuneração docente. Fonte: própria.

O INPC mostra a variação de preços no mercado e estabelece um padrão sobre o aumento ou redução do custo de vida da população. A partir dele que se mede o

\footnotetext{
${ }^{4}$ Não foram selecionados os docentes que possuem escolaridade em nível médio porque para a realização da média seria necessário utilizar docentes com a mesma escolaridade. Além disso, embora a pesquisa tenha utilizado como metodologia os professores que atuam nos anos finais e no ensino médio, ao levantar o salário não foi possível desmembrar desta forma, incluindo, portanto, os docentes da educação infantil e anos iniciais do ensino fundamental.

5 Diferentemente dos outros recortes temporais utilizados na pesquisa, neste só foi possível representar os recortes de 2011 a 2018, pois a base de cálculo utiliza como referência o ano anterior. Sendo assim, o ano de 2011 refere-se ao aumento dos preços em 2010 e assim sucessivamente. Desse modo, tornou-se desnecessário levantar o INPC de 2019, pois a base salarial da RAIS que utilizamos limita-se ao ano de 2019.
} 
reajuste salarial. Assim, para visualizar o aumento real do salário não basta comparar o crescimento de um ano para o outro, é preciso comparar com a inflação do período, pois caracteriza o aumento dos custos de produtos e serviços e dessa forma pode-se obter uma noção se houve estagnação, decréscimo ou aumento na remuneração. O cálculo deste reajuste baseou-se na seguinte equação com base na metodologia indicada pelo IBGE (2016):

$$
\text { Aumento Real }=(1+\text { Aumento }) /(1+\text { Inflação ano anterior })-1
$$

Neste mesmo capítulo também foi abordado o saldo de admissão e demissão utilizando o mesmo recorte temporal. Desse modo, no portal do CAGED-MTE escolheu-se as seguintes variáveis:

\begin{tabular}{|c|c|c|}
\hline Informações & \multicolumn{2}{|c|}{ CAGED Estatístico Id } \\
\hline Ano & mês de dezembro de cada ano (2010 a 2019) \\
\hline Conteúdo & \multicolumn{2}{|c|}{ Quantidade de movimentações } \\
\hline Movimentações & \multicolumn{2}{|c|}{ Admissão e Demissão } \\
\hline Seleção por assunto & Geográfico & $\begin{array}{c}\text { Microrregião - Rio de } \\
\text { Janeiro }\end{array}$ \\
\cline { 2 - 3 } & CBO - 2002 - Subgrupo & $\begin{array}{c}\text { Professores de nível } \\
\text { superior na educação } \\
\text { infantil e no ensino } \\
\text { fundamental. } \\
\text { Professores de ensino } \\
\text { médio. }\end{array}$ \\
\hline
\end{tabular}

Quadro 6: variáveis para levantamento da admissão e demissão. Fonte: própria.

Sobre o deslocamento dos professores na MMRJ discutidos no item 4.2, os dados levantados dos trabalhadores se referem ao Censo Escolar 2018, pois este levantamento teve início no ano de 2019, pautando-se nas informações disponibilizadas do ano anterior. Sendo assim, as variáveis escolhidas foram:

\begin{tabular}{|l|l|}
\hline Perfil docente & $\begin{array}{l}\text { sexo, município de residência, escolaridade, disciplina que leciona (química, } \\
\text { física, português, matemática, biologia, ciências, história, geografia, } \\
\text { educação física e inglês) } \\
\text { de vínculo funo que exerce na escola (1- Docente), tipo }\end{array}$ \\
\hline Informaçõóes sobre & Tipo de mediação didático pedagógica (presencial). \\
\hline
\end{tabular}

\footnotetext{
${ }^{6}$ Escolhemos apenas as disciplinas do currículo comum que estão presentes na maior parte das escolas para se obter um nível de comparação.

${ }^{7}$ Neste item o Censo só contabiliza professores da rede pública.
} 


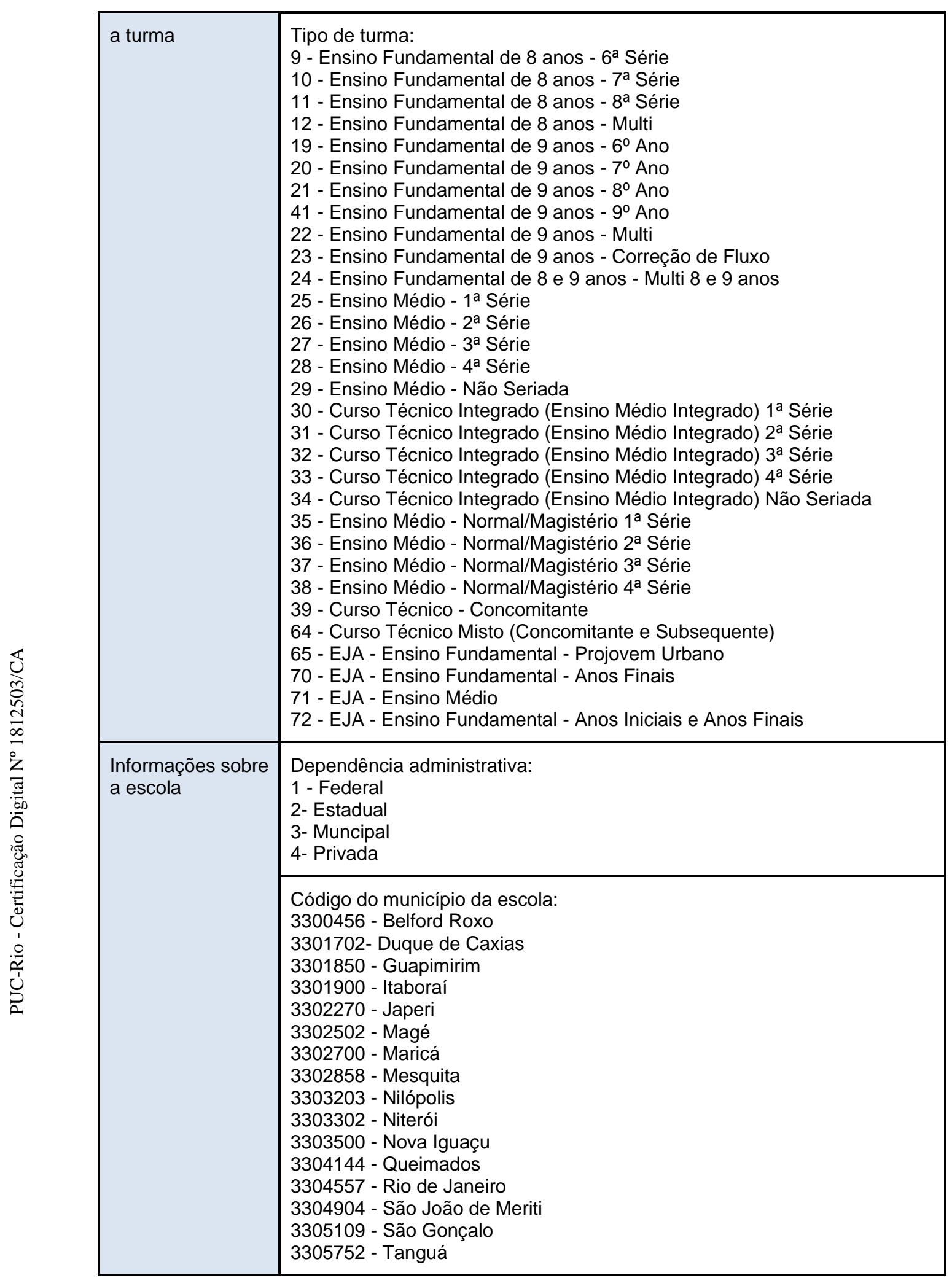

Quadro 7: variáveis escolhidas nos microdados do Censo Escolar. Fonte: própria.

Para delimitação da pesquisa foram selecionados os professores de Ensino Fundamental (anos finais) e Ensino Médio que atuam nas modalidades presenciais de ensino regular, EJA e cursos técnicos nas escolas públicas e privadas dos 16 
municípios da microrregião metropolitana do RJ encontrando um total de docentes 61.664 (seleção prévia) que representa 35\% do total de docentes do estado e 55,9\% dos professores do estado do RJ que atuam nos anos finais e ensino médio. Para melhor delimitação foram excluídos da análise os professores que atuam na modalidade FIC (formação Inicial continuada), em turmas exclusivas, na educação multisseriadas e na modalidade educação especial, o primeiro por muitas vezes não se enquadrar nas disciplinas curriculares obrigatórias comuns (história, geografia, português, matemática, química, física, educação física, artes e inglês) e o restante por não diferenciar o segmento de atuação.

$\mathrm{Na}$ segunda triagem, também foram excluídos os professores das disciplinas técnicas ou não obrigatórias no currículo comum, por se tratar de indivíduos com formações variadas e que a atuação na educação não é necessariamente a sua única atividade profissional, embora um número considerável desses professores tenha apresentado formação comum as disciplinas obrigatórias, nem todos estavam ligados à licenciatura ou lecionando disciplinas de cunho técnico.

Vale ressaltar que a dificuldade de se encontrar pesquisas que relacionam a precarização do trabalho com a mobilidade influenciou na construção desta metodologia. Além disso, a própria discussão sobre estes conceitos é bem ampla, a mobilidade incorpora vários aspectos, no caso escolheu-se trabalhar com o conceito de mobilidade pendular, no entanto, não seria suficiente abordar apenas a questão da mobilidade casa-trabalho, foi necessário criar uma nomenclatura para mobilidade escola-escola, denominada de interescolas, como falado na introdução, e que será trabalhada no tópico 4.2. Sendo assim, a metodologia pauta-se nos arranjos populacionais que definem as áreas de integração dos municípios a partir do deslocamento de pessoas.

Neste ponto houve grande dificuldade de operacionalizar a metodologia da pesquisa, pois a contagem de professores realizada pelo Censo leva em conta um docente por escola. Isso gerou números desencontrados na contagem total de professores, sobretudo porque grande parte atua em duas ou mais escolas. Este ponto também se tornou problemático para o mapeamento dos fluxos, para isso levou-se em consideração as diretrizes metodológicas do IBGE para realização de pesquisas de pendularidade em áreas metropolitanas. 
A escolha dos critérios que formam um arranjo populacional está baseada na noção de existência de relacionamentos cotidianos por grande parte da população entre dois ou mais municípios.

\begin{tabular}{|c|c|}
\hline \multicolumn{2}{|r|}{ Critérios para deslocamento nos arranjos populacionais } \\
\hline Parâmetros & $\begin{array}{l}\text { Índice > 1,00 - municípios que funcionam como focos de atração de mão de } \\
\text { obra; ou } \\
\text { Índice < 1,00 - municípios que funcionam como núcleos dormitórios; ou } \\
\text { Índice em torno de 1,00 - municípios que podem indicar ou não integração. }\end{array}$ \\
\hline $\begin{array}{l}\text { Critério de } \\
\text { integração }\end{array}$ & $\begin{array}{l}1 \text { - Forte intensidade relativa dos movimentos pendulares para trabalho e estudo } \\
\text { - tal intensidade deve ser igual ou superior a } 0,17 \text { do índice de integração. } \\
2 \text { - Forte intensidade absoluta dos movimentos pendulares para trabalho e } \\
\text { estudo - quando o volume absoluto de pessoas que se deslocam para trabalho } \\
\text { e estudo, entre A e B, é igual ou superior a } 10000 \text { pessoas (ver Apêndice } 1 \text { para } \\
\text { maiores detalhes); ou } \\
\text { 3- Contiguidade das manchas urbanizadas - quando a distância entre as bordas } \\
\text { das manchas urbanizadas } 12 \text { principais de dois municípios é de até } 3 \mathrm{~km} \text {. }\end{array}$ \\
\hline $\begin{array}{l}\text { Fórmula para } \\
\text { se obter o } \\
\text { índice de } \\
\text { integração } \\
\text { relativa }\end{array}$ & 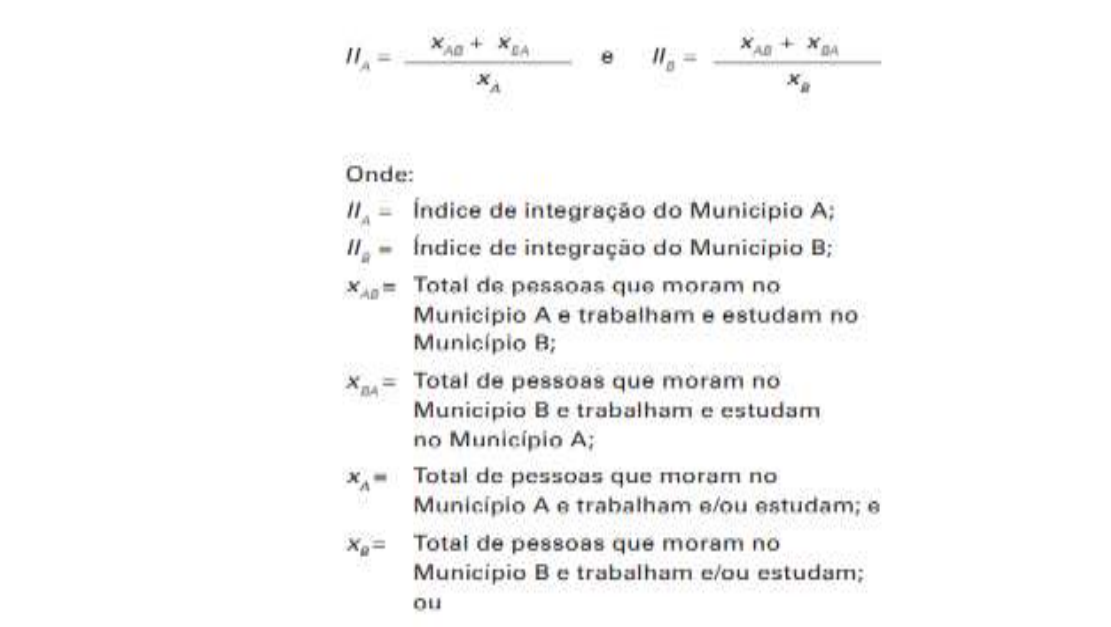 \\
\hline \multicolumn{2}{|r|}{ Mobilidade casa-escola } \\
\hline $\begin{array}{l}\text { Critérios de } \\
\text { seleção e } \\
\text { mapeamento }\end{array}$ & $\begin{array}{l}\text { Porcentagem de pelo menos } 10 \% \text { dos professores residentes que trabalham } \\
\text { fora do município em relação ao número total de professores daquele município. }\end{array}$ \\
\hline \multicolumn{2}{|r|}{ Mobilidade escola - escola } \\
\hline $\begin{array}{l}\text { Critérios de } \\
\text { seleção e } \\
\text { mapeamento }\end{array}$ & $\begin{array}{l}\text { Porcentagem de pelo menos } 10 \% \text { dos professores que trabalham em municípios } \\
\text { diferentes. } \\
\text { Porcentagem de pelo menos } 10 \% \text { dos professores que trabalham em escolas } \\
\text { do mesmo município. }\end{array}$ \\
\hline
\end{tabular}

Quadro 8: critérios metodológicos para o deslocamento pendular docente. Fonte: adaptado de IBGE (2016). 
Esta metodologia feita pelo IBGE objetiva delimitar as áreas de arranjos, definir a hierarquia e apontar a integração das aglomerações metropolitanas segundo o deslocamento da população. A pesquisa do IBGE coloca a organização espacial como o foco, o deslocamento é apenas um meio de medir esta integração, onde a maior mobilidade expressa estágios mais avançados no processo de urbanização. Neste trabalho, o foco está nos indivíduos, o deslocamento é uma forma de visualizar a precarização através da intensidade dos fluxos.

Assim, utilizou-se a metodologia do IBGE para se criar um parâmetro e visualizar a espacialidade percorrida pelos professores e a integração que estabelecem entre os municípios através de seus fluxos. No entanto, tivemos que adaptar alguns critérios, por exemplo, o órgão considera como critério de integração acima de 10.000 pessoas se deslocando, porém se fosse incorporado este valor teríamos apenas os professores da cidade do Rio de Janeiro nesta situação, pois é o único município que ultrapassa a marca dos 10 mil docentes que atuam em 2 ou mais escolas. Então optamos por nos pautar no critério de mapear todos os fluxos acima de $10 \%$ do valor total de docentes que atuam em 2 ou mais escolas.

Outro ponto é que o IBGE utiliza uma base de cálculo hipotética para definir estes 10 mil indivíduos o número de linhas de ônibus que circulam naquele horário do dia entre os municípios A e B, e vice-versa. Supondo que de 6 h às 5 h há 10 linhas de ônibus circulando de A para B e de B para A. Cada ônibus comporta 50 passageiros (segundo o critério do IBGE), portanto, haverá 500 pessoas transportadas nesse horário, soma-se as horas do dia e os itinerários e se tem uma média de deslocamento intermunicipal por dia e assim ele define como fluxos mais intensos acima de 10 mil e menos intensos abaixo de 4 mil. No entanto, esta pesquisa não partiu desta definição, pois como falado a centralidade não está nos transportes e sim nos professores. Definiu-se, portanto, o critério de maior ou menor intensidade a partir do padrão definido pelo IBGE como padrão mínimo para levantamento aqueles acima de 0,17 , ou seja, o critério foi a integração relativa entre os municípios e não absoluta pautada na estimativa dos 10 mil.

Outro ponto que também adaptamos é que nesta pesquisa é levado em conta apenas os fluxos para trabalho, não temos como medir pela base de dados os fluxos que estes professores traçam para estudo, como pós, formação continuada etc. Portanto, esta metodologia organizou-se nas seguintes etapas: 
A partir dos dados Censo Escolar 2018 levantou-se o volume de professores em cada município. Em um segundo momento, foram selecionados os dados sobre deslocamento para trabalho entre municípios e no mesmo município, ou seja, o número de pessoas que têm trabalho principal em município diferente do que moram e o número de professores que trabalham em escolas localizadas em municípios diferentes. Além disso também se calculou o eixo de maior e menor distância entre os municípios utilizando as informações disponibilizadas no Google Maps. Sobre os fluxos, o órgão explica:

Tais dados foram tratados somando-se os deslocamentos entre os municípios $\mathrm{A} \rightarrow \mathrm{B}$ com os deslocamentos entre os municípios $\mathrm{B}$ $\rightarrow$ A. Dessa forma, considera-se que não importa o sentido do deslocamento e sim a quantidade total de pessoas circulando naquela ligação $(\mathrm{A} \rightarrow \mathrm{B}+\mathrm{B} \rightarrow \mathrm{A}=\mathrm{A} \leftrightarrow \mathrm{B})$. (...) A adoção desse critério foi necessária para contemplar as áreas metropolitanas, pois os índices de integração (que medem movimento relativo) nem sempre são altos devido ao elevado tamanho de população residente em tais municípios (como é o caso de Guarulhos, na Grande São Paulo, ou São Gonçalo, no Grande Rio de Janeiro) (IBGE, 2016, p.23)

Como estamos tratando de apenas uma categoria o índice relativo torna-se suficiente para evidenciar os fluxos. Para isso, utilizamos esta metodologia:

Sendo assim, o fluxo relativo é medido pelo índice de integração obtido a partir da divisão da soma de pessoas que se deslocam para trabalho e estudo entre os Municípios A e B pelo total de pessoas que trabalham e estudam no Município A, quando se mede o índice para o Município A; ou pelo total de pessoas que trabalham e estudam no Município B, quando se mede o índice para este município. Os valores iguais ou superiores a 0,25 são considerados muito altos, o que se entende como integração populacional entre os municípios envolvidos. (IBGE, 2016, p. 23)

Desse modo, temos as seguintes classes de intensidade conforme o número de pessoas que se deslocam para trabalhar entre os Municípios $\mathrm{A} \leftrightarrow \mathrm{B}$ :

\begin{tabular}{|l|l|}
$>$ & Intensidade muito alta $\geq 0,170$ \\
$>$ & Intensidade alta $\geq 0,136 \mathrm{e}<0,170$ \\
$>$ & Intensidade média alta $\geq 0,102 \mathrm{e}<0,136$ \\
$>$ & Intensidade média baixa $\geq 0,068 \mathrm{e}<0,102$ \\
$>$ & Intensidade baixa $\geq 0,034 \mathrm{e}<0,068$ \\
$>$ & Intensidade muito baixa $\geq 0,017 \mathrm{e}<0,034$
\end{tabular}

Vale ressaltar que esses critérios de integração sintetizam vários processos envolvidos, como afirma o IBGE (2016). Assim para elaboração dos mapas de deslocamento casa-escola utilizou-se o cruzamento dos municípios de moradia e trabalho. E para os mapas de deslocamento interescolas utilizou-se o cruzamento 
dos municípios do trabalho do professor, porém levou-se em conta apenas os fluxos dos docentes comparando duas escolas, pois operacionalizar todos os fluxos que um professor realiza, necessitaria de outra base metodológica que não encontramos nas bibliografias buscadas.

É necessário ponderar que este levantamento toma como hipótese o deslocamento interescolas ao longo de um mesmo dia, mediante as informações reveladas pelo Indicador de Esforço Docente. Desse modo, sabemos que nem todos os professores irão se deslocar no mesmo dia entre escolas diferentes ou municípios diferentes, mas parte-se do princípio de que a maioria sim, pois em diversas redes a forma de contratação é em regime parcial permitindo essa flexibilidade de estar em vários lugares ao longo do dia.

No tópico 4.4 buscou-se coletar algumas dessas percepções no final da pesquisa através da aplicação de questionário voltada para a mobilidade, mas ciente de que este tipo de metodologia não consegue representar a natureza dos problemas em questão, apenas é parâmetro para olharmos para a mobilidade e para o trabalho na perspectiva desses sujeitos e do vivido. Foi levantado nesta etapa as seguintes informações:

\begin{tabular}{|l|l|}
\hline Perfil Docente & $\begin{array}{l}\text { Sexo, faixa etária, local de residência, se atua como professor dedidação } \\
\text { exclusiva, quantas escolas atua, séries e disciplinas que leciona, tempo no } \\
\text { magistério, se o magistério é a única fonte de renda, carga horária por } \\
\text { semana, se participa ou participou de algum programa de hora extra, }\end{array}$ \\
\hline Sobre a escola & Nome, endereço, turno que atua, tipo de contrato, \\
\hline Sobre a mobilidade & $\begin{array}{l}\text { Tempo médio de deslocamento (casa-trabalho e escola-escola) } \\
\text { Se necessitou mudar de residência por causa da distância para o trabalho, } \\
\text { se necessita ou necessitou de residência temporária para o trabalho, se já } \\
\text { realizou permuta ou transferência e os motivos, se necessitou adquirir } \\
\text { veículo para se locomover, se a escola fornece algum tipo de suporte para } \\
\text { locomoção, se durante o deslocamento exerce alguma atividade } \\
\text { relacionada ao trabalho. }\end{array}$ \\
\hline Perguntas pessoais & $\begin{array}{l}\text { Se acredita que trabalhar em uma escola contribuiria para melhorar sua } \\
\text { condição de trabalho. } \\
\text { O quanto e de que forma a mobilidade impacta no trabalho docente }\end{array}$ \\
\hline
\end{tabular}

Quadro 9: variáveis levantadas no questionário. Fonte: própria.

Como esta etapa não estava prevista e foi adicionada na reta final as perguntas foram adicionadas na medida que surgiam as ideias. Assim, algumas questões obtiveram número menor de respostas, como mostram o anexo 1 . O total de respondentes foi de 154 professores e a pesquisa esteve disponível durante 3 meses, para sua realização foi utilizada a plataforma SurveyMonkey. 


\subsection{Sobre as fontes de dados}

Como vimos os indicados abrangem uma gama de aspectos da realidade social acerca dos mais diversos assuntos como educação, segurança, saúde, mobilidade, entre outros. Eles são relevantes na medida que revelam informações para se compreender determinado problema. Assim, vale explicitar aqui um pouco de suas respectivas finalidades.

$\mathrm{Na}$ educação temos várias pesquisas disponibilizadas pelo INEP com a finalidade de avaliar e educação brasileira, dentre eles, o Censo Escolar e o Saeb que abordamos aqui. O Censo Escolar é o principal instrumento de coleta de informações da educação básica, a partir dele outras pesquisas são realizadas, seja pelo próprio órgão ou instituições associadas. É realizado de forma colaborativa entre as secretarias estaduais e municipais de educação e possui a participação de todas as escolas do país. Ele abrange todas as etapas da educação básica e dessa forma consegue realizar monitoramento de um conjunto de indicadores e a partir disso elaborar estudos e levantamentos que influenciam na criação e fiscalização de políticas públicas.

Em seus microdados, fornece informações sobre o perfil discente e docente, além de fornecer dados sobre formação, instituição formadora, vínculo empregatício, disciplinas, escolas, etapas e redes que atuam e informações sobre a infraestrutura das escolas. No entanto, não possui todas as informações, pois depende da declaração do encarregado censitário de cada escola, para preenchimento correto de todos os itens. A partir destas informações realizam relatórios anuais e as chamadas Sinopses Estatísticas sintetizando estas informações.

Ao realizarmos a seleção prévia como falado na metodologia encontramos milhares de docentes que apresentavam informações omissas. Além disso, na parte dos vínculos empregatícios, a pesquisa não faz um levantamento dos professores que trabalham na rede privada, comprometendo a análise mais completa sobre as condições de trabalho, como também não fornece dados sobre a remuneração docente, necessitando complementar estas informações com dados da RAIS.

Já o Saeb é um conjunto de avaliações externas na escala nacional que realiza diagnósticos sobre a qualidade do ensino a partir do aluno, ou seja, levanta fatores que podem interferir no aprendizado do aluno. Desse modo, realiza testes e 
questionários amostrais aplicados à estudantes de diversas redes e etapas de ensino, inclusive a educação infantil.

E a partir disso, oferecem indicadores que segundo o INEP avaliam a qualidade do ensino e influencia na distribuição de recursos para aprimoramento das políticas educacionais. E desse modo, as médias dos estudantes compõem o Índice de Desenvolvimento da Educação Básica (Ideb).

É a partir desse levantamento que o INEP criou o Painel Educacional que apresenta informações agregadas sobre o cenário educacional de estados e municípios utilizando informações provenientes do SAEB e do Censo Escolar. Explicitam um panorama levando em consideração três eixos de pesquisas: informações sobre a trajetória dos alunos, como matrículas, média de estudantes por turma, estudantes incluídos, matrículas em tempo integral, taxa de aprovação, taxa de reprovação, taxa de abandono e taxa de distorção idade-série (INEP, 2020). Aborda resultados pautados na aprendizagem dos alunos, como a participação de estudantes e escolas no Saeb também inclui dados sobre o contexto da educação, como indicador de nível socioeconômico, indicador de complexidade da gestão Escolar, indicador de adequação da formação docente, indicador de regularidade docente, indicador de desenvolvimento da Educação Básica e chama atenção o indicador de esforço docente, utilizado nesta pesquisa.

Nesse indicador levam em consideração: o número de escolas em que atua; o número de turnos de trabalho; o número de alunos atendidos e o número de etapas nas quais leciona. Realizam uma média por município ou estado, ou pela média total das escolas municipais de determinado estado ou pela soma das escolas estaduais em um determinado município. Assim, organizam estes docentes em categorias de forma ordinal, onde as mais elevadas indicam maior esforço por parte do professor, como mostrado no quadro 4.

Em relação aos dados de deslocamento, utilizamos como fonte do Censo 2010, o levantamento é feito a cada 10 anos e abrange diversos aspectos sociais em escala nacional. A pesquisa utilizou o método amostral e levantou informações de deslocamento para trabalho e estudo na população acima de 10 anos de idade em diferentes níveis territoriais (país, municípios, regiões metropolitanas, microrregiões, mesorregiões, bairros e outros). A partir disso, o IBGE, responsável pelo estudo, reuniu as informações da população que se desloca como sexo, cor, rendimento nominal mensal, carga horária de trabalho semanal, local de moradia e 
local de trabalho, tempo de deslocamento diário, faixa etária, nível de instrução, setor do trabalho principal e elaborou as classificações dos arranjos populacionais do país.

Sobre as informações referente à trabalho e renda utilizamos a RAIS, instituída pela lei $\mathrm{n}^{\mathrm{o}} 76.900$ de 1975 e vinculada ao MTPS, tem como objetivos fornecer informações sobre a atividade trabalhista no país, provendo dados e elaborando estatísticas sobre o mercado de trabalho para serem disponibilizadas às entidades governamentais. Ela é baseada na declaração de todas as empresas privadas e órgãos públicos que empregam trabalhadores independentemente do tipo de vínculo empregatício. Assim, esse instrumento tem a capacidade de prover informações laborais de docentes de todas as escolas, incluindo as de administração federal, estadual, municipal e privada.

A PNAD/IBGE também coleta informações sobre a remuneração docente, porém Alves e Sonobe (2018) alertam que esta fonte não capta as características de uma ocupação específica e não se mostra uma fonte de grande confiabilidade, pois apesar de ter uma grande cobertura populacional, considera a população como um todo, mas não há garantia de representatividade quando se refere à determinadas carreiras. Além disso, os autores afirmam que esta fonte tem sido aprimorada e tem sido utilizada para o monitoramento da meta 17 do PNE que prevê a questão da valorização da carreira, porém nos relatórios do observatório do PNE não há menção à remuneração dos docentes da rede privada, assim torna-se uma medida que falha ao negligenciar esta informação.

Considerando que a Rais é um sistema de coleta de informações que visa à geração de estatísticas sobre o mercado formal de trabalho, cujos respondentes são as áreas especializadas dos empregadores que geram as folhas de pagamento (departamento de pessoal próprio das secretarias de estados e municípios ou empresas de contabilidade que prestam serviços para os órgãos de governo) e utilizam sistema eletrônico fornecido pelo Ministério do Trabalho específico e com orientações sobre como prestar as informações (BRASIL, 2016), sem dúvida, essa fonte tem potencial destacado quanto à possiblidade de coletar dados que favoreçam o cálculo do indicado que expresse um conceito mais próximo do esperado. Nesse aspecto, a questão formulada para a coleta do rendimento do trabalhador na Pnad não é específica e, ${ }^{17}$ por isso, não é possível saber se o valor respondido é o bruto, líquido, vencimento básico, etc. E, quando o interesse é gerar indicadores para analisar uma carreira específica, isso pode ser um problema por não conseguir captar as especificidades. Além disso, o respondente nem sempre é o próprio professor, pois na Pnad é possível que o respondente seja 
qualquer morador do domicílio em condições de responder o questionário (IBGE, 2013) (ALVES E SONOBE, 2018, p. 471).

Desse modo, a RAIS, segundo os autores apresenta a vantagem de ser censitária e assim, abrange a categoria dos professores, mediante as informações prestadas pelas redes. Em 2014, o INEP organizou um levantamento sobre a remuneração docente no Brasil vinculado à implementação do PNE e utilizou como referência a RAIS, mesclando informações do Censo Escolar e verificou que entre 80 a 95\% do corpo docente estava presente no levantamento dessa fonte, portanto, mostra-se como uma fonte segura. Completam os autores:

\begin{abstract}
Além disso, apresenta os desafios de obter $100 \%$ das informações de todas as redes de educação do país, conforme já apresentado. Nesse sentido, a Rais, pela sua finalidade e pelos avanços que tem tido quanto à cobertura populacional desde 2006, parece ser a fonte que apresenta mais condições de atender a esse quesito, uma vez que uma mudança no questionário da Pnad para atender às demandas de uma ocupação específica, de acordo com a finalidade da pesquisa, não seria viável. (ALVES E SONOBE, 2018, p. 471)
\end{abstract}

Outro índice é o INPC que tem por objetivo corrigir o poder de compra dos salários, através do levantamento das variações de preços em relação à população assalariada. O IBGE é o órgão responsável por este levantamento. Engloba as famílias com rendimentos de 1 a 5 salários-mínimos, segundo a pessoa assalariada na residência e que vivem nas áreas urbanas ou regiões metropolitanas. Ela é importante para medir o aumento real dos salários. Nesta pesquisa foi utilizada como uma informação coadjuvante em relação à RAIS, explicitando o aumento real do salário docente na MMRJ.

Outros índices coadjuvantes como a Talis 2018, aplicada pela OCDE para um grupo de 46 países, possuindo resultados a cada 5 anos sobre a educação mundial. A Pesquisa Internacional sobre Ensino e Aprendizagem (Talis), tradução de Teaching and Learning International Survey, possui o foco é avaliar o ambiente de ensino e aprendizagem com base na percepção do entrevistado, e as condições de trabalho dos professores e diretores nas escolas. No Brasil, sua aplicação e o tratamento dos dados é responsabilidade do Inep. Outra fonte de dados elaborada pela OCDE é o relatório do Education at a Glance de 2018, um estudo realizado anualmente pelo Programa de Indicadores dos Sistemas Educacionais - INES com o objetivo de apresentar a coleta de dados educacionais internacionais com dados sobre o investimento financeiro, desenvolvimento profissional, salários dos professores, 
etc. Também utilizaremos o relatório simplificado utilizaremos o Anuário Brasileiro da Educação Básica (2018), referente aos dados do Censo Escolar de 2018 realizado pelo Movimento Todos pela Educação em parceria com a Editora Moderna.

\subsection{Limites e riscos da pesquisa}

É importante ressaltar que os indicadores utilizados nesta pesquisa não explicam totalmente o problema, apenas fornecem informações que permitem visualizar um quadro da realidade. A complexidade da questão envolve uma análise multidisciplinar e também minuciosa, tanto teórica quanto empírica, algo difícil de se alcançar no curto período de dois anos, tempo no qual a pesquisa foi realizada. Vale dizer que estabelecer a relação entre trabalho e mobilidade buscando a gênese desse processo, dialogando com as leis que produzem este cenário, indo até os dados, sobretudo no que tange esta categoria, que além de numerosa imprime no espaço múltiplos fluxos, não foi algo fácil. Assumo também os riscos metodológicos aqui apresentados, pois a escala escolhida necessitaria de maior tempo de pesquisa para desmembrar-se sobre ela e desvendar aspectos específicos da realidade docente de cada município. Assim, embora a intenção tenha sido compreender o problema olhando para uma dimensão macro, corre-se o risco de buscar uma totalidade superficial.

Nesse sentido, os erros fazem parte da trajetória científica, embora necessitem ser combatidos e superados. Morin (2000) afirma que cometemos erros porque nosso organismo possui mais conexões com o nosso psíquico do que com o mundo exterior. Assim, cada mente pode mentir para si próprio, desfigurar determinado acontecimento, tanto de forma positiva quanto negativa, assim, as influências de nossas experiências influenciam a condução de nossas ações, a ciência não está livre dessas influências.

Ao mesmo tempo, ele aponta que pesquisas que se pautam totalmente na racionalização creem que os dados retratam um sistema lógico perfeito, fechado, porém no qual sua base fora mutilada ou com fundamento em informações falsas, cujo sistema não permite críticas. Já a racionalidade permite uma verificação lógica, coerente e aberta, o diálogo com a realidade.

Portanto, há de se ter cuidado para não cairmos no que o autor chama de cegueiras paradigmáticas - um paradigma é um princípio de seleção de ideias que selecionam 
ou excluem conceitos que lhes são contrários. O paradigma está oculto na lógica e é através dela que privilegia determinadas operações em detrimento de outras. Os indivíduos conhecem, pensam e agem segundo paradigmas presentes em suas culturas. Para o autor, a disjunção é o princípio que norteia o paradigma simplificado, já o paradigma complexo necessita da conjunção para compreender o real e por isso torna-se tão difícil alcançá-lo isoladamente, mas um conjunto de pesquisas tendem a obter visões amplas. Segundo o autor, o paradigma cartesiano separa sujeito e objeto, alma e corpo, espírito e matéria, sentimento e razão, entre outros antônimos que permitem uma dupla visão do mundo. Assim um paradigma pode ao mesmo tempo revelar e ocultar.

Nesse sentido, aponto os riscos conceituais de tentar unir estes dois processos, a mobilidade e a precarização. Sozinhos configuram-se como processos complexos e abrangentes, relacioná-los na perspectiva docente foi desafiador, mas ao mesmo tempo este trabalho mostra-se como um embrião para a continuidade futura ou mesmo para colaborar com outras pesquisas, uma vez que esta relação não se estabelece somente na categoria docente, pelo contrário, com o advento do aumento do desemprego, da uberização do trabalho e da expansão dos fluxos, diversos trabalhadores têm experimentado novas formas de percorrer o espaço, para uns a hipermobilidade e para outros a imobilidade, situando-se muitas vezes em condições de vida mais precárias que os docentes. Nesse sentido, cuidou-se também para não cair na relação causa e consequência entre a mobilidade e o trabalho.

Tentar explicar estes conceitos tão amplos é uma algo necessário diante de um mundo que se complexifica, interliga e sobrepõe processos. Como afirma Morin (2000) para enfrentarmos os problemas no mundo atual é necessário buscar as múltiplas dimensões da questão. Para o autor, o global ultrapassa o contexto, porque é o conjunto das partes que se ligam ao todo, mas apenas o conhecimento das partes não é suficiente para conhecer o todo, o todo não é somente a soma das partes, pois ele possui qualidades e propriedades que não são encontradas nas partes, e estas de forma isolada não geram qualidades advindas do todo. $\mathrm{O}$ multidimensional comporta as dimensões históricas, econômicas, sociológicas e religiosa do ser humano. São unidades complexas movidas pelas emoções humanas incorporando a dimensão biológica, psíquica, social, afetiva, racional.

O autor explica que o complexo não é o sinônimo de difícil. O conceito se remete ao que é tecido junto, ou seja, que se interagem de forma interdependente, as partes 
e o todo, o todo e as partes, as partes entre si. Apesar dos progressos dos conhecimentos especializados durante o século XX essa fragmentação dificultou o conhecimento do contexto do global e da complexidade. Nesse sentido, apesar da pesquisa ter se desenrolado principalmente, à luz de referências teórico conceituais da Geografia, sabe-se que outros conhecimentos seriam necessários para se compreender a questão como os estudos na economia, na sociologia, na educação e nas políticas públicas.

Outro risco que assumo é em relação à escolha dos autores, pois partiu da tentativa de responder às lacunas entre esses dois conceitos, por isso, apesar da discussão teórica ter sido majoritariamente pautada em autores que utilizam o materialismo dialético para explicar as contradições do espaço e do trabalho, compreendidos como produto histórico e não como fenômenos isolados fruto da livre escolha individual, como pensam alguns autores, buscou-se combinar referências que explicitam claramente os conceitos aqui abordados e nos ajudam a responder às questões do real, embora esteja ciente de que certos autores não utilizam esta perspectiva em suas obras, mas foram de grande contribuição sobretudo para conceituação dos temas aqui trabalhados, como Standing.

Sobre isso Morin (2000) afirma que as sociedades tendem a domesticar os indivíduos por meio de mitos e ideias, mas os indivíduos podem ao mesmo tempo domesticar essas mesmas ideias. É necessário ter cuidado com o mito e com a ideologia, pois elas destroem os fatos. "Devemos manter uma luta crucial contra as ideias, mas somente podemos fazê-lo com ajuda de ideias." (MORIN, 2000, p.30). Eis aí um paradoxo!

As dicotomias e a racionalização impostas pelo método tradicional são antagônicas ao método dialético, pois uma representam uma falsa compreensão do real, na qual é conduzida pela classe hegemônica que torna simplista a representação do ser e dissimula a realidade, tornando os fatos verdades superficiais, focando apenas na aparência dos fenômenos, o que Kosik (1969) denomina de pseudoconcreticidade, na qual torna-se prejudicial uma vez que cerceia a liberdade e o poder de pensamento humano, modificando o sentido do trabalho, por exemplo. "A dialética é o pensamento crítico que se propõe a compreender a coisa em si e sistematicamente se pergunta como é possível chegar à compreensão da realidade", afirma KOSIK (1969, p.15). 
Desse modo, há uma tendência de naturalizar da realidade fenomênica que tende à imposição do mundo mercantil como algo imutável e inquestionável. Afirma ele: "o pensamento que destrói a pseudoconcreticidade para atingir a concreticidade é ao mesmo tempo um processo no curso do qual sob o mundo da aparência se desvenda o mundo real" (KOSIK,1969, p. 16).

Nesse sentido, o mundo que nos é apresentado e sua essência fenomenológica nem sempre é cognoscível ou digna de neutralidade ao indivíduo para que ele possa avaliar a realidade de forma crítica. A essência das coisas ou sua concreticidade é ocultada por sua aparência. Nessa ausência de sentido, o objeto passa a ser visto como independente de quem o criou e passa a ser reduzido à práxis utilitária cotidiana. Kosik (1969) afirma que essa falsa compreensão do real se baseia na compreensão da coisa pela coisa e não a coisa pelo movimento que a constitui. Para o autor:

O pensamento comum é a forma ideológica do agir humano de todos os dias. Todavia, o mundo que se manifesta ao homem na práxis fetichizada, no tráfico e na manipulação, não é o mundo real: é "o mundo da aparência" (Marx). A representação da coisa e da realidade: é a projeção, na consciência do sujeito, de determinadas condições históricas petrificadas. (KOSIK, 1969, p.15)

Portanto, a teoria dialética toma como pressuposto o materialismo histórico, não parte nem somente do objeto, nem tampouco do sujeito abstrato, mas da atividade prática social dos indivíduos históricos e concretos. Assim, o homem pode ser entendido como um ser criativo e inserido em relações sociais concretas mutáveis ao longo do tempo, no qual exerce atividade social consciente e teleológica, ou seja, munida de intencionalidade, o que é genuinamente o conceito de práxis que se materializa em trabalho e produção. Todo trabalho físico e toda produção constituiria, portanto, o exercício ativo da vida social como prática humana material, e a educação é um dos elementos constitutivos dessa práxis.

Conforme Ciavatta (2014), para a dialética, o conhecimento é totalizante e a atividade humana é um processo de totalização, em um movimento espiral que nunca é alcançado. Isso significa dizer que toda criação humana ou todo objeto que o homem percebe é parte de um todo e que subordinado a determinadas ações, responderá de forma interligada a outros problemas de ordens distintas. "A dialética da totalidade é uma teoria da realidade em que seres humanos e objetos existem em situação de relação, e nunca isolados", (Ibidem, p.195). 
Assim, a totalidade concreta precede à pergunta fundamental sobre o que é realidade e que impõe imediatamente outra questão sobre como podemos conhecer a realidade, algo que se impõe de forma intransigente, pois se a entendermos como totalidade de todos os fatos, caímos nos limites do conhecimento humano em que se torna impossível conhecê-los, pois apresentarão facetas e aspectos desconhecidos para o homem.

Desse modo, um objeto só pode ser estudado inserido na totalidade, na qual incorpora uma relação com os diversos objetos que a compõe e levando sempre em conta as relações que o determinam, econômicas, sociais e culturais (CIAVATTA, 2014, p.195).

Sobre isso, vale ponderar sobre as escolhas de certas metodologias que se calçam nos preceitos científicos para esconder e ao mesmo tempo facilitar a implementação dessa ordem hegemônica e ilusória. Desse modo, apesar de todas as fontes de dados terem sido disponibilizadas pelo INEP, há de se ter cautela com o que mostram, pois como foi falado anteriormente a educação hoje está mergulhada em uma rede mundializada de interesses mercadológicos que parte dos mais diversos atores. Pesquisas como a EAG, a Talis e a ABEB possuem resultados que não são necessariamente confiáveis, uma vez que partem de instituições que engendram hoje um discurso neoliberal em prol exclusivamente da obtenção de lucro.

Nas palavras de Ball, eles tentam "fazer do mercado a solução óbvia para os problemas sociais e econômicos" (BALL, 2014, p. 59). Desse modo, produzem material muitas vezes superior e mais completo do que os estudos feitos por órgãos públicos. Financiam pesquisas, estudos e artigos, promovem congressos, palestras, financiam campanhas, influem em metodologias de pesquisas educacionais realizadas pelo governo, pressionam para imposição de avaliações, reforçam uma dualidade público e privado através de rankings e comparações, sempre deteriorando o público, fazem parte e indicam pessoas para ocupar importantes cargos no governos na pasta de educação, pautando-se sempre nos valores de mercado: livre concorrência, liberdade individual e propriedade privada. Completa o autor: "estão trabalhando para mudar a percepção do público sobre os problemas sociais no Brasil, incluindo a Educação" (BALL, 2014, p. 60).

Há diversos exemplos de ONGS e sites que foram criados para divulgar estudos sobre a educação e influenciar na aprovação de políticas como a reforma do Ensino Médio, a implementação da BNCC, como por exemplo. O movimento "Todos pela 
Educação", uma ONG financiada por grandes empresas brasileiras de diversos setores da economia, que elabora estudos e faz constante monitoramento da educação no país influenciando além destas pautas, outras de suma importância, como o Novo Fundeb, que falarei melhor no tópico 2.4 .

Outro exemplo desta forte influência das edu-business, como nomeia Ball (2014), foi a criação de um observatório do PNE que leva em conta os resultados das variáveis de contexto analisados pelo Saeb. O Plano Nacional da Educação (PNE) foi sancionado a partir da lei $\mathrm{n}^{\circ} 13.005$ aprovada em 2014 e se baseou na CF de 1988, na LDB de 1996 e no Atual Plano Nacional da Educação, estabelecendo as Diretrizes e Bases da Educação Nacional. Esta política tem vigência de 10 anos e propõe 20 metas a serem atingidas na educação nesta década. Os resultados influenciam no destino de verbas para estados e municípios. Portanto, é sabido o risco de se utilizar essas fontes, ao mesmo tempo comparando com outras fontes mais confiáveis foi possível ver que alguns aspectos referentes ao trabalho docente se confirmaram, por isso escolheu-se mantê-las.

Vale dizer que a metodologia da pesquisa foi sendo construída na medida que surgiam novas informações e assim ampliava-se a necessidade de buscar outras respostas, por isso, utilizou-se diversas fontes e recortes espaciais diversos. A princípio, na discussão teórica sobre precarização e mobilidade buscou-se situá-la na escala nacional para depois adentrar as especificidades da microrregião. Além disso, tratar a microrregião fluminense por si só não é algo fácil, devido sua complexidade e os processos que atuaram na produção deste espaço que de um lado se homogeneízam e de outro se fragmentam por apresentarem espaços de desenvolvimento desiguais e classes sociais diferentes.

Outra observação sobre a trajetória da pesquisa é que ela surgiu a partir da observação, estudos, conversas com professores e da minha própria trajetória como docente, onde a precarização e a mobilidade interescolas são fortemente vivenciadas. Observei que em diversos espaços escolares que transitei - durante a graduação como estagiária nas redes estadual, municipal e federal, e após formada, em escolas privadas e cursos preparatórios - que tanto jovens docentes, quanto professores mais experientes que atuam na rede pública ou privada queixavam-se sobre diversos aspectos em sua profissão, dentre eles, por viverem sob grande incerteza, pressão, sobrecarga e estavam fortemente desmotivados, além de imobilizados diante das transformações que estão ocorrendo. Obviamente, esta 
realidade não representa a todos, embora os discursos tenham similaridade e possam retratar um momento político e econômico, eles não explicam a totalidade, pois são carregadas de valores, visões de mundo e subjetividades.

Outro ponto é que para trabalhar com os microdados do Censo é preciso utilizar softwares que conseguem ler o volume de informações. Para isso, seria necessário conhecimentos técnicos e estatísticos mais profundos, algo que se tornou uma limitação devido ao tempo da pesquisa, mesmo assim, análises básicas utilizando o software SPSS e ArcGis foram feitas para cumprir os objetivos propostos. ${ }^{8}$

Outra dificuldade é que no decorrer da pesquisa foram encontradas algumas informações desencontradas quando se comparou diferentes fontes, por exemplo, ao confrontar dados de admissão e demissão do CAGED/MTE e o número de vínculos do Censo Escolar como mostra o item 4.2.

Outro ponto refere-se ao recorte temporal escolhido, quando a pesquisa começou os primeiros dados a serem investigados foram o $\mathrm{ABEB}$, os relatórios técnicos e microdados do Censo Escolar e as pesquisas internacionais EAG e Talis, todas publicadas em 2018, ano de início da pesquisa. Na medida em que a metodologia foi avançando e outras questões surgiram passou-se a incorporar fontes mais recentes referentes ao ano de 2019, inclusive do próprio Censo Escolar, para estabelecer comparações como as evoluções de salário, matrículas, $\mathrm{n}^{\circ}$ de docentes, vínculos, como apontado no item 4.2. Além disso, nessas análises sobre a evolução da remuneração e das formas de contratação foi utilizado um recorte dos últimos 10 anos para se visualizar as transformações latentes ao trabalho docente em uma escala comparativa de antes e depois do governo Dilma, pois a partir de 2016 viuse que as transformações importantes na ampliação destas formas de precarização, sobretudo do ponto de vista legal com a incorporação de novas regras trabalhistas, além de mudanças na própria conjuntura econômica do país, como mostra o item 2.4 .

E por fim, é necessário apontar o grande risco de se adaptar uma metodologia utilizada para definição dos arranjos para medir os fluxos docentes, embora este também seja uma das etapas da definição dos arranjos. No entanto, a bibliografia

\footnotetext{
${ }^{8}$ Vale dizer que a intenção da pesquisa seria fazer uma análise espacial mais profunda da escala escolhida, porém devido à pandemia da COVID-19, a metodologia e os objetivos da pesquisa tiveram de ser reduzidos pela impossibilidade de acessar os laboratórios da universidade, onde se encontram os programas para elaboração de mapas e de análise estatística. Sendo assim, a metodologia teve de ser readaptada para as ferramentas disponíveis no domicílio da autora.
} 
de Cresswell e os estudos que levantamos sobre deslocamento utilizavam a ideia de integração entre as localidades A - B e B - A. E utilizavam critérios semelhantes ao usado pelo IBGE. Nesse sentido, foi privilegiado o estudo deste órgão mesmo sabendo que este modelo pode ser contestado ou futuramente aprimorado para dar conta das especificidades de certa categoria.

\subsection{Referencial Teórico}

De acordo com o exposto acima, discutir o trabalho na sociedade atual é de grande relevância para compreender como se chega nessa fase de condições desfavoráveis ao trabalhador. Para isso, utilizaremos as ideias de Lukács (2013), Meszáros (2014), Lima (2014) e Ciavatta (2014) com a finalidade de debater o trabalho. Sennett (2008) e Foucault (2009) abordam o sacrifício dos corpos no cotidiano, isso nos permite compreender a relação do desgaste físico e os deslocamentos.

Antunes (1997 e 2000), Harvey (1992, 2012 e 1980), Alves (2005) nos ajudarão a compreender o contexto em que surge a precarização. As ideias de Druck (2002) e Standing (2014) definem quem é esse precariado. Tavares (2006) discute o processo de flexibilização que permite dentre outras coisas a ampliação da mobilidade diária e acúmulo de empregos. Utilizamos o conceito definido por Silva (2018) de precariado professoral para especificar a situação docente.

Já no segundo capítulo, temos a contribuição de Balbim (2016), Cresswell (2006), Augé (2010) para definição da mobilidade e delimitação de seu tipo, como também Becker (2006), Póvoa-neto (1997) e Gaudemar (1979) colaboram com as correntes teóricas que abrangem a mobilidade e a circulação da força de trabalho. Souza (2013), Soja (1993), Massey (2008) e Santos (2006) estabelecem uma relação entre o espaço e os fluxos, onde os autores colocam em questionamento a relação tempomobilidade, pondo em cheque este processo de flexibilização que exige agilidade, fluxos e acúmulo de tarefas no ambiente laboral e retira os direitos do cidadão ao espaço.

O espaço será tratado como conceito central para compreender a mobilidade, onde os conceitos de território e lugar entram como coadjuvantes para se entender a implicação de ações sobre o território e a mobilidade no cotidiano. Marandola (2011) e Barbosa (2016) aprofundam a discussão da mobilidade na escala intraurbana e a relação com o processo de metropolização. Outras fontes também foram utilizadas de modo a complementar essas discussões. 


\section{Capítulo 2. O trabalho docente no século XXI: a precarização em pauta}

Ao pensarmos a precarização do trabalho docente atualmente é necessário, primeiramente, adentrarmos na discussão da finalidade se destina o trabalho de modo geral. Interpretar os paradigmas postos a tal realidade exige a centralização do sujeito neste processo.

A categoria dos professores encontra-se imersa em uma complexidade de ações que tornam a produção intelectual um produto de baixo valor. O processo de deterioração do trabalho tem sido percebido a partir de medidas como as privatizações, as terceirizações, o desemprego estrutural, a informalidade, a ineficácia da atuação dos sindicatos como aponta Antunes (2000), configurando-se como as diversas facetas da precarização docente no Brasil que condiciona esses trabalhadores a buscar novas alternativas mesmo que lhes custe grande esgotamento físico, para a complementação salarial como forma de subsistência, uma vez que esses processos culminam na baixa remuneração, favorecendo, consequentemente, um cotidiano de rotinas desgastantes, sobretudo, quando se fala das áreas urbanas com seus deslocamentos pendulares diários intensos, que os submete às relações perversas de trabalho e de condições exaustivas da prática docente.

Nesse sentido, o sacrifício do corpo, sobretudo quando se trata da rotina do ir e vir é derivado da acumulação que maximiza o cotidiano alienado. Assim não tomamos consciência da realidade na qual estamos inseridos e das relações de poder que nela existem. O tempo e o espaço nesse sistema estão cada vez mais comprimidos, tornando as relações sociais mais instáveis, sob a imposição da flexibilidade do trabalhador como algo positivo.

Diante de tais problemáticas, é necessário aprofundar essas discussões e compreender de que modo o trabalho docente encontra-se atualmente, para que se possa pensar possibilidades para superação desse cotidiano fetichizado ${ }^{9}$. Por conseguinte, pretende-se aqui discorrer brevemente sobre o sentido do trabalho, bem como sua apropriação no sistema capitalista e os mecanismos que intensificaram o processo de precarização da categoria dos professores. Entendendo a educação como sistema de condicionamento para perpetuação desse sistema, fazse necessário também o debate acerca dessa problemática.

\footnotetext{
${ }^{9}$ Refere-se ao culto ou adoração aos objetos, no quais tornam-se carregados de poder e valor.
} 
Nesse sentido, sabendo dos limites do conhecimento humano e partindo do pressuposto de que a visão de conjunto é sempre provisória e não consegue esgotar os aspectos da realidade, pois aquela se mostra sempre mais complexa do que o conhecimento que dela retiramos, recorremos, portanto, a sintetização da natureza do trabalho para explicar sua estrutura essencial diante de uma determinada situação.

\subsection{Notas sobre trabalho}

Para pensarmos a relação precarização e educação é preciso antes de tudo inseri-la em um complexo de múltiplas relações sociais que constituem o trabalho. Assim, a compreensão de como a precarização atinge o trabalho em seus diversos segmentos perpassa pela busca da natureza desses processos e da relevância disso na vida cotidiana. Assim, na concepção dialética compreende o trabalho como a mola propulsora para o desenvolvimento humano, pois é a partir dele que o homem produz a si mesmo e exerce sua atividade criadora e contemplativa. Nesta teoria, o trabalho é visto como uma atividade histórica na qual permitiu ao homem se diferenciar dos outros animais. Para Lukács (2013, p.65), essa separação consciente configura-se como necessária ao trabalho e base para a existência humana. "É por meio dessa dualidade que o homem sai do mundo animal." (LUKÁCS, 2013, p. 66). Assim, o trabalho nasce na sociedade humana como uma necessidade vital.

Frigotto (2014) afirma que ele se configura como uma atividade que produz elementos necessários à vida humana no que tange à dimensão de necessidades elementares da espécie. Mas também através de uma produção consciente o homem produz a si mesmo e se reconhece como participante do processo de trabalho. É transformado em uma espécie de mediação metabólica entre a humanidade e a natureza e que, segundo Lukács (2013), é o precedente para a constituição do ser social, ou seja, sem o trabalho a vida cotidiana social não se reproduziria.

Antes de tudo, o trabalho é um processo entre o homem e a Natureza, um processo em que o homem, por sua própria ação, media, regula e controla seu metabolismo com a Natureza [...] Ele põe em movimento as forças naturais pertencentes a sua corporalidade, braços e pernas, cabeça e mão, a fim de apropriarse da matéria natural numa forma útil para sua própria vida. Ao atuar, por meio desse movimento, sobre a Natureza externa a ele e ao modificá-la, ele modifica, ao mesmo tempo, sua própria natureza (MARX, 1983, p. 149). 
Dito isso, entende-se que a existência do homem é definida por sua ação sobre a natureza com objetivo de transformá-la conforme suas necessidades, não só adaptar-se a ela, mas adaptá-la a seus interesses, o que é diferente dos outros animais que apenas se adaptam a ela, ou seja, não agem sobre ela. Essa ação é o que garantiu a singularidade humana. Lukács (2013) afirma que o caráter histórico do ser social não permitiu reconstruir o caráter orgânico do homem e que a ciência tenta decifrar o salto ontológico, ou a gênese do orgânico e inorgânico, que permitiu a passagem das conexões simples (ser orgânico) para as complexas (ser social). Assim, somente o trabalho teria em sua essência ontológica um caráter de transição, uma vez que a relação entre homem e natureza se estabelece tanto de forma inorgânica (ferramenta, matéria prima, objeto de trabalho) como de forma orgânica (atividades triviais para subsistência).

Para o autor, o trabalho humano nasce em função de suas necessidades físicas e da sua auto existência, como, por exemplo, o trabalho de autorrealização, que se difere do trabalho para necessidade. Portanto, o caráter do ser social se estabelece na tríade: orgânico-inorgânico-social. E é a partir do trabalho que nasce as características essenciais do ser social, é ele que realiza a transição do homem meramente biológico para o homem que trabalha. Nesse sentido, as categorias constituintes do ser social seriam: trabalho, linguagem, cooperação e divisão do trabalho, que marcam noções de consciência desse ser. Sendo assim, afirma que o trabalho perpassa por uma noção de atividade-fim para produção de valores de uso, ou seja, refere-se à apropriação da natureza para satisfazer as necessidades do homem. Segundo o pensamento do autor, o trabalho possui uma intencionalidade ligada a consciência do ser chamada de pôr teleológico ${ }^{10}$, o que para Marx é algo que só existe dentro da práxis humana, ou seja, inserida no sentido do trabalho. Diz ele:

Para Marx, o trabalho não é uma das muitas formas fenomênicas da teleologia em geral, mas o único ponto onde se pode demonstrar ontologicamente um pôr teleológico como momento real da realidade material (LUKÁCS, 2013, p.51).

Nesse caso, só podemos falar em teleologia quando nos referimos ao trabalho como algo objetivado e posto para um fim. Enquanto a natureza opera sobre o caráter de causalidade. Embora não neguem de modo algum que ambos façam parte do

10 Conceito utilizado por Lukács que significa aliança entre inteligibilidade, consciência e operatividade, para ele o ser humano é o único ser da natureza capaz de agir de forma teleológica 
processo de trabalho, participam ativamente do modo de produção diante da apropriação humana.

A teleologia, conforme aponta Mészáros (2006, p.111), é sempre aberta e não permite fixidez de um sistema fechado em nenhuma fase, pois trata-se de uma teleologia histórica, uma vez que ele afirma que toda a necessidade humana é sempre histórica e que o objetivo da história humana é a realização da essência humana, mesmo que primeiramente ocorra de forma alienada e posteriormente se transforma em algo positivo, estabelecida como uma necessidade interior.

Nunca se pode alcançar um ponto na história no qual seja possível dizer: "agora a substância humana foi plenamente realizada". Pois uma tal delimitação privaria o ser humano de seu atributo essencial: seu poder de "automediação" e "autodesenvolvimento" (MÉSZÁROS, 2006, p.111).

No entanto, tal condição de finalidade do trabalho que permitiu o desenvolvimento do ser social esbarra na dimensão dos processos de dominação e produção de valores de uso e que, embora tenha sua motivação inicial no abastecimento das necessidades sociais, orientam-se apenas para a transformação dos objetos naturais, culminando em um pôr-econômico de valores de uso e de troca (Ibidem, p. 77). Eis que aí surge uma dupla face do trabalho; um pôr-teleológico destinado a necessidade e satisfação, ou seja, o trabalho se apresenta numa dimensão objetiva, como fonte de sobrevivência de garantia de seus bens de primeira necessidade, como também na dimensão subjetiva, ligada à criação e à contemplação. Porém, a segunda feceta refere-se à liberdade do domínio de ações sobre o sujeito humano criadas pelo próprio homem. E esse é o salto do desenvolvimento humano: não agir apenas como ser puramente biológico ou encantado pelo fetiche da técnica, tornando-a como objeto central de sua ação (ibidem, p.79).

A autora CIAVATTA, 2014, p.211 afirma que essas duas categorias - liberdade e necessidade - são importantes para entender as mediações da socialidade humana. É nesse âmbito que o trabalho ocupa papel central, pois pode ser entendido como:

...relação criadora do homem com a natureza, ou como atividade de autodesenvolvimento físico, material e espiritual, como manifestação da vida e como realização do reino da liberdade. Mas o trabalho apresenta-se, também, nas suas formas históricas de sujeição, de servidão ou de escravidão, ou como o trabalho moderno, assalariado, flexibilidade ou desregulamentado, formas específicas da produção da existência do capitalismo (LUKÁCS, 1978 apud CIAVATTA, 2014, p.212) 
Acerca disso, Lima (2014, p. 245) afirma que a liberdade humana é contraposta pela sujeição da atividade prática à materialidade, tornando o homem dependente das coisas. Mészáros (2006, p. 179) completa que esta dependência deriva das mediações de primeira ordem, relacionadas às condições vitais para a reprodução do homem e as de segunda ordem, que dizem respeito ao trabalho coagido, explorado, aos meios alienados de produção, aos objetivos fetichistas da produção, às relações de poder do mercado. Segundo ele, este último não apenas controla os indivíduos, objetivando a expansão do capital, mas também os ilude como "agentes livres” em relação à margem perceptível de suas ações. Na medida em que o capital se apropria do trabalho como mediação de primeira ordem, ou seja, trabalho apenas como sujeição aos meios de subsistência, transforma a relação homem-natureza para atender às suas necessidades de segunda ordem, tornando tal processo alienante para o trabalhador que se torna distanciado dos meios de produção, da cultura de produzir, dos objetos produzidos e de sua identidade (CIAVATTA, 2014, p.212), ou seja, o objetivo final do trabalho torna-se a produção de bens e capital de forma desumanizada.

Com relação à segunda dimensão, o trabalho consciente não se torna um direito humano, e sim parte de uma ordem unilateral, exploratória e eminentemente política que privilegia determinados grupos. Passa-se então a entender o trabalho em uma dimensão social utilitária que visa a atender determinadas classes e que essas mesmas definirão os usos e o acesso dos demais. É neste sentido que o trabalho perde seu caráter positivo para a natureza humana e passa a ser entendido como meio de alienação para justificar a dominação, a divisão de classes, os privilégios e os discursos hegemônicos.

Assim, o trabalho que deveria ser uma propriedade interna do homem se torna algo exterior ao trabalhador e o torna alienado. A alienação corrobora para colocar a atividade espontânea no trabalho forçado como meio de se obter fins essencialmente animais (comer, beber, procriar) e culmina na ausência de liberdade. Nessa alienação, muitos indivíduos passam a trabalhar por obrigação e não por satisfação.

Segundo Mészáros (2006, p.141), o problema da liberdade necessita ser discutido numa relação tríplice: grau de liberdade com relação à necessidade natural; grau de liberdade com relação ao poder de interferência de outros homens através de relações humanas determinadas e a liberdade para exercer os poderes essenciais do 
homem. Sobre isso, ele questiona até que ponto o homem é livre para exercer seus poderes essenciais? A política pode ser um caminho para intervir de forma positiva ou negativa nessa liberdade, mas outros fatores a influenciam, ou seja, para ele o problema da liberdade deve ser resolvido no nível em que surge. Estabelece-se, portanto, uma relação tríplice: do homem com a natureza, com outros homens e consigo mesmo; sendo este último designado como o poder essencial.

$\mathrm{O}$ que autoriza o marco constitucional do sujeito a partir do surgimento da modernidade na história é o fato de que, nas formas alternativas de sociedade, o homem é a finalidade da produção enquanto que, na sociedade atual, a produção se converte em finalidade do homem e a acumulação de riqueza na finalidade da produção. No seio desse complexo de contradições, as formas históricas de exploração do trabalho vão se desdobrar em uma forma específica e ideológica (pretensamente universal) concernente ao ideal de liberdade: o trabalho livre ou remunerado (LIMA, 2014, p.253).

Conforme o autor (2006, p.142 e 143), embora seja um consenso que as relações capitalistas, comparadas às relações feudais, que eram eminentemente políticas, aumentaram consideravelmente a liberdade humana, a liberdade do homem em relação a necessidade natural continua sendo sempre uma conquista relativa e os poderes essenciais do homem só podem ser exercidos na medida em que isso é possibilitado pela maior ou menor limitação da liberdade humana com relação à natureza. Nesse sentido, as forças produtivas não são governadas pela associação consciente, ou seja, o caráter irracional do processo visando à produtividade e ao lucro prevalece sobre as necessidades humanas reais. Portanto, a potencial força libertadora das novas capacidades produtivas é desperdiçada, enquanto a esfera de poderes estranhos a que o homem está submetido é ampliada em vez de ser reduzida.

Com relação a isso, Lima (2014) explica que essa submissão está ligada à sujeição do trabalho humano. O sujeito aparece como livre, mas na verdade não é. Ao tornarse força de trabalho é livre, porém é também coisificado. Ele é livre, pois em tese pode optar para quem vai trabalhar, diferentemente do período escravocrata em que o sujeito estava completamente subordinado a classe dominante. Contraditoriamente, o sujeito torna-se submisso a classe que controla os meios de produção e consumo, porém sob o argumento da liberdade. Assim o sujeito, na 
modernidade, surge a partir das separações, alma e corpo, sociedade natureza, sujeito e objeto.

E, assim, ele é livre apenas sob determinadas condições. A capacidade criativa é cerceada e isso favorece a reificação (falta de consciência) ou alienação. Em outras palavras, para a teoria crítica um dos grandes problemas dessa conjuntura é o cerceamento da liberdade individual, segundo a qual o trabalho não deve se manter limitado à esfera das necessidades. Neste ponto, ao pensarmos o trabalho docente no Brasil, temos a percepção que embora livre recai em diversos mecanismos de controle que se originam em diferentes escalas, seja internamente na própria escola, nas esferas administrativas superiores, através das avaliações nacionais, por meio de órgãos internacionais, deliberações políticas ou por correntes econômicas. Esses diversos meios que pressionam e determinam as condições de trabalho do professor engendram meios para suprimir o tempo livre, como de planejamento de aulas, ou tempo para atividades da vida privada.

\begin{abstract}
A luta dos seres humanos é no sentido de abreviar este tempo de trabalho constrangido pela necessidade a fim de gerar tempo livre, tempo de liberdade ou de escolha. Este é um tempo verdadeiramente criativo e, portanto, genuinamente humano. (FRIGOTTO, 2014, p.62)
\end{abstract}

Para Netto \& Carvalho (2012, p. 40) a alienação contamina e sufoca a vida cotidiana, pois "na objetivação do trabalho, este deixa de ser uma atividade vital, criadora, prazerosa, para se tornar um mero meio de subsistência" (Ibidem). Assim, as relações sociais objetificadas transformam-se em instrumento de dominação e opressão. Na sociedade produtiva, a relação entre os homens e a si próprio torna-se estranhada, porque uma vez que o trabalho se torna exterior aos homens, também o seu produto assume uma forma que lhes é estranha; ou, antes, o produto de seu trabalho não possui uma forma, não é um objeto, mas uma coisa. Enfim, ele não pertence ao trabalhador, pois sua conversão em coisa e, de imediato, em propriedade privada de outrem, expurga, como que em sacrifício da vida, o teor criativo de seu espírito, sua qualidade de sujeito ativo. O sujeito-trabalhador não se vê no objeto produzido por si mesmo, não o possui, pois, esse objeto é propriedade privada de outrem, bem como todos os objetos e instrumentos necessários para a sua produção (LIMA, 2014, p. 259-260).

É na esfera da vida cotidiana em que os comportamentos acríticos, fetichizados, padronizados e uniformes reforçam o comportamento do mundo moderno que o 
individualismo, a neutralidade e a competição permitem que as grandes decisões sejam tomadas e incontestadas na esfera política, econômica, cultural e espiritual por determinados agentes. O trabalho nesse contexto perde seu valor. Resta apenas o emprego e este torna-se cada vez mais escasso no mundo tecnológico moderno, criando uma cisão alienante: os empregos passam a ser encarados como privilegiados, os não empregados como marginais.

Santos (1987) afirma que a alienação nasce com indivíduo, logo nós já nascemos com a tendência de nos alienarmos e, para sair dessa condição é necessário realizar uma descoberta essencial; para isso a liberdade é condição para se chegar a não alienação. $\mathrm{O}$ autor se refere a uma liberdade para além dos modos de consumo que a sociedade está pautada: uma liberdade para a cidadania. Mészáros (2006, p. 92) afirma que o conceito das relações sociais é precisamente o conceito da alienação, podendo ser observado através de três movimentos: o trabalhador é esmagado pelas classes dominantes e pelo estado.

Ainda segundo ele, a autoalienação do trabalho na realidade se manifesta através do trabalho assalariado, da propriedade privada, intercâmbio, do dinheiro, da renda, lucro, entre outros (Ibidem, p.97). Para ele os reflexos dessa alienação se fundamentam por intermédio da religião, da filosofia, do direito, da economia, da ciência, da educação, entre outros. Nesse sentido, em uma sociedade alienada, os processos são reduzidos em si mesmos, pois são feitos de maneira inconsciente, determinados por uma série de necessidades alienadas e destinadas a produzir maior alienação. O homem passa a estar submetido aos instrumentos que ele mesmo cria (Ibidem, p.98). Assim, o conhecimento e a ciência seguem o mesmo sentido, seu caráter fragmentado não é meramente acidental, afirma ele: "para se atingir o meio para fins alheios é necessário que toda a atividade produtiva seja alienada" (Ibidem, p.99).

Lima (2014, p. 262) aponta que neste sistema de alienação o trabalhador troca ou vende sua capacidade criativa e isto corresponderia a supressão do sujeito. Nesse sentido, sendo a escola um espaço para construção de saberes e de desenvolvimento da capacidade criativa do indivíduo, e os professores, agentes centrais na condução desses objetivos, tem-se uma dualidade neste espaço, pois as pressões externas para moldá-lo como um ambiente preparatório para este tipo de trabalho são gigantes. E isso se dá para escolha do currículo, pelo tipo de avaliação, pela organização do 
espaço, pelas atividades que nela são desenvolvidas, dentre outras formas de captação.

Foucault (2009) afirma que esse processo de dominação é estruturado em relações de poder, na qual a escola funciona como um espaço de controle. A lógica da organização deste sistema consistiria em transformar tudo em mercadoria, nesse sentido a escola é coisificada e se torna mercadoria. Assim, os objetivos educacionais para construção do conhecimento envolvem também conhecimentos voltados para manutenção da ordem sociometabólica do capital, e seus atores, os professores, por exemplo, trabalhando (inconscientemente) para manutenção desta condição. Dessa forma, se o trabalho docente está inserido nesta lógica e se permanece subjugado e controlado acaba por reproduzir em seus alunos o processo alienante do cotidiano a que estão submetidos.

A educação institucionalizada, especialmente nos últimos 150 anos, serviu - no seu todo - ao propósito de não só fornecer os conhecimentos e o pessoal necessário à máquina produtiva em expansão do sistema do capital, como também gerar e transmitir um quadro de valores que legitima os interesses dominantes, como se não pudesse haver nenhuma alternativa à gestão da sociedade, seja na forma "internalizada" (isto é, pelo indivíduos devidamente "educados" e aceitos) ou através de uma dominação estrutural e uma subordinação hierárquica e implacavelmente impostas (MÉSZÁROS, 2008, p. 35).

Segundo Postone (2014, p.47) esses inúmeros indivíduos que não controlam a própria atividade produtiva ou o que produzem são dominados por esta atividade, constituindo-se uma forma abstrata de dominação. É nesse sentido que a ideia de alienação nos ajuda a visualizar o não só o processo de estranhamento, mas sobretudo, entendê-la como uma construção histórica (Ibid., p.47).

Ao pensarmos as sociedades industriais temos imediatamente a visão do filme de Charles Chaplin, tempos modernos, onde o trabalho se mostrava completamente distante do trabalhador das fábricas, pois funciona segundo uma rotina materialmente sistematizada cujo objetivo é produzir materiais, seu produto pode ser refeito, desfeito, consumido e vendido (TARDIF \& LESSARD, 2009, p. 32). O que se difere do objeto do trabalho docente, onde o produto final é a interatividade e o objeto é essencialmente humano. Embora haja concordância por muitos autores que esses indivíduos também são mercadorias, os autores alertam para o perigo de reduzir completamente, em todas as funções, trabalhadores às coisas. Uma vez que as relações humanas envolvem necessariamente juízos de valor, afetividade e outras 
emoções, elas possuem a capacidade de superar, mesmo que parcialmente, a alienação. Afirmam eles:

(....) o trabalho sobre outrem levanta questões de poder e até de conflitos de valores, pois seu objeto é, ele mesmo, um ser humano capaz de juízos de valores e detentor de direitos e privilégios que os símbolos, as coisas inertes e os animais não possuem. (Ibidem, p.33)

O autor também mostra que por tratar-se de um trabalho subjetivo pode estar sujeito à abusos de poder, sobretudo quando se atua sobre indivíduos mais vulneráveis, como crianças, idosos, entre outros. Assim, é preciso que atue de forma ética. A questão da obrigatoriedade da educação coloca os professores na posição de convencimento constante aos clientes quanto ao benefício de sua ação. Os clientes involuntários podem tornar ineficaz a prática do professor, é preciso motivá-los constantemente, uma vez que se encontram em um ambiente que os condiciona a ter disciplina e a seguir ordens, moldando-os para o mercado de trabalho.

Desse modo, professores motivados podem desenvolver habilidades e pensamento crítico nos alunos para além da formação exclusiva dos conteúdos programáticos (Ibidem, p. 33-35). Mas como fazer isso se a conjuntura política e econômica cerceia a liberdade, autonomia e desmotiva estes trabalhadores? Tratando-se de uma função que exige contínua preparação e criatividade, é necessário estar estruturada de modo que favoreça o desenvolvimento de competências necessárias ao trabalho intelectual, para além do viés informativo e técnico, mas também cidadão. No entanto, as novas formas de organização do trabalho ainda tratam o magistério como uma prática secundária em relação ao trabalho material e produtivo (TARDIF \& LESSARD, 2009, p. 17). Dizem os autores:

A docência e seus agentes ficam nisso subordinados à esfera da produção, porque sua missão primeira é preparar os filhos dos trabalhadores para o mercado de trabalho. O tempo de aprender não tem valor por si mesmo; é simplesmente uma preparação para a verdadeira vida, ou seja, o trabalho produtivo, ao passo que, comparativamente, a escolarização é dispendiosa, reprodutiva, ou quando muito, reprodutiva. (Ibidem)

Para além deste modelo industrial, focado na separação do trabalho, Postone (2014) aponta alguns dispositivos de natureza simbólico-ideológica que se sobrepõem em grande escala aos princípios da distinção, como os princípios de acumulação flexível que impõem a expansão de mercados, uma ordenação em que o crescimento econômico dependa da exploração do trabalho assalariada, um dinâmica 
tecnológica que reflete no menor uso de mão de obra visando o menor custo possível e a maior produtividade. Este processo de acumulação apoia-se na flexibilidade do trabalho, dos produtos e padrão de consumo.

Assim, vale destacar os efeitos explicitados em diversas escalas a respeito dessa ordem simbólica-subjetiva vigorante nas sociedades contemporâneas, como mostra Antunes (2000, p.18) e Harvey (2012) as economias em expansão tem gerado o empreendedorismo e o individualismo, o deslocamento das unidades produtivas ocasionando a desconcentração geográfica das atividades e o desemprego, o poder financeiro gerando a neoliberalização das políticas estatais, além da profusão da exclusão social e do aumento de indivíduos sem acesso a bens básicos, a desindustrialização causando a falência da estrutura fordista que agora se vê migrando para a adoção da eletrônica, através da financeirização e volatilidade dos capitais e a indeterminação da economia, além da reprodução social econômica estar causando uma valorização e desvalorização do capital em ritmos acelerados o que causa uma degradação e precarização não só do trabalho como também da vida humana.

Nesse sentido, Harvey (2012) afirma que esses acontecimentos se baseiam na fragmentação entre os atos da vida cotidiana, cisão entre o pensar e o agir, atrelado a uma indeterminação dos processos cognoscível do mundo social. Relaciona-se também com o fechamento da experiência valorizando as aparências e desconectando os fatos. Além de tornar o presente como o espaço do possível, a instantaneidade é valorizada, ou a chamada perda de consciência do tempo histórico. E por fim, o prazer diante do caos, a pobreza banalizada e a aceitação de fenômenos degradantes passa a ser naturalizado no cotidiano das pessoas.

Assim, o pós modernismo estaria atrelado a uma ideologia-cultural cuja acumulação flexível encontra-se no centro das esferas econômicas e culturais. E que devido ao seu ritmo acelerado comprime a relação espaço-tempo, o que pode provocar uma perda de identidade com o lugar, e a uma cristalização das estruturas sociais (Ibidem). Nesse sentido, culminam para uma tendência de estetização do cotidiano, uma mercadorização do tempo e das memórias, diminuição do trabalho assalariado, ampliação do trabalho flexível não contabilizado.

Para Rosso (2017), essa flexibilidade que surge ao final do século XX, na forma de informalidade, sobretudo nos países periféricos é vendida como algo positivo, modernizador e potencialmente gerador de empregos, pautada no indivíduo no qual 
se exige competência, responsabilidade, eficácia e resultados. Esse modelo de trabalho tem forte ligação com o tempo. Como aponta o autor, a vida encontra-se dividida em dois momentos, tempos de trabalho e de não trabalho, na era da acumulação flexível esses momentos se confundem, tornando móveis as fronteiras que os separam. Isso resulta na possibilidade de acumulação de riquezas nas mãos dos detentores do capital, seja ele o Estado ou um ente privado. Além disso, o termo flexibilidade incorpora a noção de multitarefas e dilui os saberes específicos para determinada função. Assim, aparentemente o trabalho parece ser maleável, mas não necessariamente diminui. A remuneração e o tipo de contratação também deixam de serem fixas, tornando o indivíduo responsável por si próprio, ou seja, o único trabalhador de sua própria empresa, em outras palavras, a pessoa jurídica se sobrepõe a pessoa física. Nesse sentido, com os momentos da vida recortados, mentes e corpos são sacrificados em busca de mais de um meio de sobrevivência nesta sociedade de capital fluída. Embora isto seja mais comum no ambiente empresarial, nas escolas essa lógica tem sido incorporada e aparece frequentemente na disposição fluida de carga horária permitindo sobrecarga de trabalho, na informalidade, na não remuneração das horas de planejamento de aula, na atuação em outras funções da escola ou outras disciplinas. Portanto, a rigidez ou, em lado oposto, a flexibilidade não se trata de meras abstrações e sim processos concretos da organização do trabalho, que em diferentes modos, e às vezes combinadas geram formas de precarização.

Tanto esta lógica flexível quanto a organização industrial de produção ganharam espaço no ambiente escolar, seja pelas regras impessoais, burocráticas, pelo sistema de vigilância punitivo, recompensador, pelo controle comportamental padronizado, dividido e planificado impostos pelos modelos laborais mais tradicionais (TARDIF \& LESSARD, 2009, p. 24 e 25).

No entanto, como apontam os autores, quando se trata de um trabalho imaterial no qual o produto são seres humanos ou que ocorre em um contexto de interações humanas, como é o caso do trabalho docente, faz retornar a humanidade de seu objeto, o indivíduo é posto diante de questões complexas de poder, de afetividade, ética inerentes à interação humana. É neste contexto que se pode encontrar a superação da asfixia de um sistema rígido e alienado. Embora a escola seja marcada pela fixidez de horários e regras reproduzindo o sistema de doutrinação para o trabalho mecânico ou tecnológico, é ao mesmo tempo formadora de conhecimento 
e cultura, ou seja, no mesmo ambiente que se reproduz o condicionamento reside a possibilidade de superação deste, já que se trata de relações humanas onde juízos de valor se imprimem nesse contexto.

A docência se encontra no centro desta formação imaterial, cognitiva, pois age sobre e com o outro. Ao observamos os países centrais vemos grandes investimentos nestes trabalhadores e na educação, uma vez que eles possuem papel central do ponto de vista político e cultural. Segundo os autores (TARDIF \& LESSARD, 2009), é o ensino a forma dominante de socialização e de formação das sociedades modernas há mais de dois séculos e continua em expansão. Como apontam os autores, os professores são uma das principais peças da economia das sociedades modernas, junto com os profissionais da saúde representam a principal fatia orçamentária dos Estados Nacionais. Portanto, faz-se necessário aprofundar a discussão acerca de suas condições atuais de trabalho.

\subsection{A precarização do professor no Brasil}

Como vimos, as formas de organização o trabalho dita a organização da sociedade. O ambiente escolar não foge à essa regra, embora seja um espaço em que o trabalho se configura de maneira bem específica. A singularidade do trabalho do professor consiste numa dupla organização, conforme aponta Tardif \& Lessard (2009, p. 41), de um lado o trabalho codificado por aspectos previsíveis, prescritos, obrigações formais, normas, regulamentos, procedimentos, temporizado, calculado, tudo que é previsível e rotineiro. Nesse ponto, afirmam eles que a docência se parece muito com os ofícios e às profissões burocratizadas, repetitivas e padronizadas. A autonomia é amarrada e a identidade do trabalho é definida pelo seu status e pelo papel que exerce. O trabalho é exteriorizado e portanto, sujeito à alienação, já que se mostra como uma atividade instrumentalmente controladora e formal regida por uma racionalidade forte (Ibidem, p.42 e 43).

O outro o aspecto é o lado flutuante, informal, flexível, sobretudo porque o ambiente escolar por mais rígido que pareça, é complexo e impossível de controlar, é marcado por interações humanas, por acontecimentos inéditos, caracterizado por uma racionalidade fraca, como afirmam os autores. $O$ conhecimento é personalizado, pois deriva da experiência da vivência profissional, onde a rotina é modelada pelo improviso. Nesse caso, o ensino seria parcialmente dotado de autonomia, onde as relações humanas e os acontecimentos do cotidiano se 
sobrepõem a rigidez dos programas, mesmo que estes vigorem na maior parte do tempo e das ações. Essa combinação de elementos é chamada pelos autores de um trabalho potencialmente contraditório e heterogêneo.

A organização escolar na qual o trabalho é desenvolvido tampouco é um mundo fechado; ela não é autônoma, mas participa de um contexto social mais global no qual está inscrita. Esse contexto social não é uma abstração sociológica, nem um horizonte longínquo ou situado "fora" da escola. Pelo contrário, tal contexto social está tanto "dentro" quanto "fora" da escola, é ao mesmo tempo individual e coletivo. (...) Este mesmo contexto social se exprime também no fato de a identidade dos diferentes agentes escolares - inclusive os professores, obviamente - nunca ser totalmente determinada pela organização escolar, já que os mesmos participam de outras organizações sociais (...) Em resumo, é uma organização aberta, de fronteiras porosas, permeáveis a influências múltiplas. (TARDIF \& LESSARD, 2009, p. 44)

Portanto, para compreendermos o processo de precarização é necessário analisarmos tanto as ações externas quanto as internas que garantem essa degradação das condições de trabalho. Como dito, no Brasil essas ações externas acerca da precarização ganharam força diante da constituição de um Estado provedor de ensino público e do crescimento da demanda deste sobretudo após a década de 80, com a constituição federal de 1988 garantindo a todos o acesso universal e obrigatório ao ensino, temos portanto, a ampliação da demanda escolar, a obrigatoriedade do ensino e a transformação da profissão docente em uma função de massa. Atrelado a isso, políticas públicas implementadas de forma a perpetuar a desigualdade de classes e burocratização das normas escolares garantiram meios para cercear a liberdade e valorização da escola e do trabalho do professor.

Silva (2018) conta que estas políticas relacionam as medidas deliberadas no Consenso de Washington que influenciaram a implementação da agenda neoliberal na América Latina, transformando a escola para se adequar a reestruturação produtiva. Onde os organismos internacionais ditam reformas que influenciam fortemente no trabalho docente. Ela afirma que esta precarização não é homogênea, possuem nuances e estratificações dentro do funcionalismo público.

A precarização perpassa pelo setor estável do professorado nas redes públicas de educação básica sob as mais diferentes nuances e perspectivas, no entanto, ela é ainda mais intensa nos estratos de trabalhadores docentes que vivenciam as condições mais desprovidas de direitos e em condições de instabilidade cotidiana dentro do espaço público, dada pelo trabalho temporário, 
contratos de tempo parcial, por hora, entre outros. (SILVA, 2018, p. 213)

Essas políticas implementadas nos anos 1990 com reformas, privatizações e instabilidade contribuíram difusão da flexibilidade na categoria, crescendo o que a autora chama de o precariado professoral. Ela diferencia esses professores daqueles que estão em situação de empregos estáveis e formais, ou seja, se encaixam nesta categoria aqueles que estão em regimes temporários e sem garantias.

Identificamos o precariado professoral como sendo a fração mais mal paga e explorada dos professores brasileiros, em geral certificada, em sua maioria jovem, em busca de um primeiro emprego no magistério público, em início de carreira ou ainda não formados e que desenvolvem vínculos de trabalho precários; distinto do professorado estável-formal, concursado, que tem organização sindical e possui acesso a benefícios e direitos trabalhistas, além da perspectiva de carreira profissional. (SILVA, 2018, p.217)

Para a autora, estes trabalhadores experimentam uma grande flexibilidade salarial. Além disso, nas palavras da autora, o termo "compreende os trabalhadores que não conseguem se inserir nas atividades empregatícias e que, por isso mesmo, perambulam de ocupação em ocupação para garantir seus meios de sobrevivência." (SILVA, 2018, p. 216). Ela relaciona este processo ao conceito marxista de exército industrial da reserva que contribui para manter ou reduzir os salários, que amplia o número de pessoas dispostas a inserir-se rapidamente no mundo do trabalho, diante de quaisquer condições, e assim tornam-se terceirizados, pejotizados e da uberizados.

Sobre esses termos, vale explicar que a pejotização consiste em formas de burlar a legislação trabalhista por meio da imposição feita pelo empregador da contratação de pessoas jurídicas. Assim, ele se desonera de encargos para obter maiores lucros. Este tipo de contratação tem se ampliado consideravelmente no setor de serviços. Já a uberização trata-se de uma nova relação de trabalho, cuja exploração da mão de obra ocorre por grandes empresas globais do ramo tecnológico que através de aplicativos e plataformas digitais estabelecem a ausência de qualquer tipo de vínculo formal, responsabilidade e obrigação em relação às pessoas cadastradas que são denominados de prestadores de serviços.

Embora este precariado professorial seja composto majoritariamente por jovens, a questão da desvalorização salarial na profissão é algo presente em outras faixas 
etárias e em vários níveis de ensino. Se comparado aos demais trabalhadores com ensino superior esta discrepância é maior. Segundo dados divulgados pelo ABEB (2018, p.111), enquanto a média salarial nacional dos docentes (apenas ensino básico) é de R $\$ 3.823,00$, a do conjunto dos trabalhadores brasileiros graduados é bem superior, cerca de $\mathrm{R} \$ 5.477,05$. Como podemos ver a seguir:

\begin{tabular}{|c|c|c|c|c|c|c|c|}
\hline \multicolumn{8}{|c|}{$\begin{array}{c}\text { Rendimento médio dos professores da Educação Básica e de profissionais de outras áreas com curso } \\
\text { superior - Setores público e privado - Brasil - } 2012 \text { - } 2018 \text { (Em R\$ - valores de dezembro de 2018, } \\
\text { corrigidos pelo INPC) }\end{array}$} \\
\hline Categoria & 2012 & 2013 & 2014 & 2015 & 2016 & 2017 & 2018 \\
\hline $\begin{array}{l}\text { Professores da Educação Básica - } \\
\text { rede pública }\end{array}$ & $3.576,18$ & $3.887,99$ & $3.814,60$ & $3.902,00$ & $3.584,94$ & $3.775,72$ & $3.823,00$ \\
\hline Profissionais da área de Exatas & $8.086,89$ & $7.290,37$ & $7.879,07$ & $7.400,37$ & $7.060,55$ & $7.187,92$ & $7.542,11$ \\
\hline Profissionais da área de Humanas & $6.583,21$ & $6.522,88$ & $5.910,68$ & $6.351,38$ & $5.779,99$ & $5.526,84$ & $6.070,59$ \\
\hline Profissionais da área de Sáude & $7.423,52$ & $7.196,21$ & $7.005,60$ & $7.305,87$ & $7.076,00$ & $7.168,15$ & $7.718,36$ \\
\hline $\begin{array}{l}\text { Média de rendimento dos } \\
\text { profissionais com curso superior }\end{array}$ & $5.882,03$ & $5.957,88$ & $5.737,00$ & $5.804,72$ & $5.467,72$ & $5.591,29$ & $5.477,05$ \\
\hline $\begin{array}{l}\text { Proporção da média salarial dos } \\
\text { professores em relação a média } \\
\text { dos profissionais com curso } \\
\text { superior (em \%) }\end{array}$ & 60,8 & 65,3 & 66,5 & 67,2 & 65,6 & 67,5 & 69,8 \\
\hline
\end{tabular}

Tabela 1: comparação entre o rendimento médio dos professores da Educação Básica e de profissionais de outras áreas com curso superior - Fonte: ABEB (2018, p.112).

A pesquisa Education at a Glance (INEP, 2018) elaborada pela OCDE aplicada em parceria aplicada à 250 mil professores de dos 48 países pesquisados, concluiu que o Brasil possui uma das piores médias salariais, inclusive a pior média na América do Sul, com problemas ao que tange o plano de carreira e sem aumentos efetivos. Para calcular o rendimento dos educadores nos diferentes países, o estudo converteu todos os ganhos em dólar e fez o cálculo do poder de compra dos salários em cada um dos países. A partir disso, foi observado que os professores brasileiros recebem uma remuneração um pouco superior aos divulgada pelo $\mathrm{ABEB}$, pois na EAG (INEP, 2018) levam em conta a média da remuneração dos professores da rede básica e superior, equivalente a uma média de US\$13.971 ao ano, cerca de US\$ 1.164 por mês, sendo os países europeus líderes do ranking, como por exemplo, Luxemburgo que está em primeiro lugar, com remuneração variando entre US\$ 96.104 e US\$ 109.420 dólares/ano para a educação infantil e ensino médio, respectivamente, uma diferença gritante. 
Outra questão é a desigualdade de salários entre os níveis de ensino, segundo o relatório Brasil e Estados Unidos possuem as maiores diferenças em nível subnacional entre os países analisados. As diferenças entre as regiões internas também merecem destaque, a unidade da Federação com o maior salário representa quase o triplo do salário das UFs que pagam menos aos professores do ensino fundamental e 5,6 vezes mais quando essa análise é levada para o ensino médio (EAG/OCDE, 2018, p.23). O relatório também aponta discrepâncias salariais consideráveis no Brasil e Suécia entre os gêneros e entre os grupos etários entrevistados (25-34 anos; 35-44 anos; 45-54 anos e 55-64 anos), mas, para Brasil e Suécia, já nos outros países essa diferença é mínima.

Nesse sentido a desvalorização salarial geraria o fenômeno de busca de mais empregos na mesma área ou em outras, isso corrobora com a narrativa pejorativa que se têm da docência como uma profissão de "bicos". Segundo o Anuário Brasileiro, uma quantidade significativa de professores leciona em mais de uma instituição de ensino simultaneamente, sendo o Rio de Janeiro o estado com maior média nesse quesito, cerca de $21 \%$ dos professores atuam em dois estabelecimentos e 7,5\% em três ou mais (Ibidem, p. 113). Essa sobrecarga de escolas salientam a mobilidade docente como um processo para além da disposição espacial das escolas.

\begin{tabular}{|c|c|c|c|c|c|c|c|}
\hline \multicolumn{8}{|c|}{$\begin{array}{l}\text { Docentes na Educação Básica por quantidade de estabelecimento em que lecionam por } \\
\text { etapa de ensino - Brasil - } 2018\end{array}$} \\
\hline \multicolumn{8}{|c|}{ Quantidade de estabelecimentos } \\
\hline & & \multicolumn{2}{|l|}{1} & \multicolumn{2}{|l|}{2} & \multicolumn{2}{|c|}{3 ou mais } \\
\hline Modalidade & Total & Total 1 & $(\%) 1$ & Total 2 & (\%)2 & Total 3 & $(\%) 3$ \\
\hline Educação Básica & 2.226 .423 & 1.751 .405 & 78,7 & 383.487 & 17,2 & 91.531 & 4,1 \\
\hline Creche & 300.136 & 260.873 & 86,9 & 35.616 & 11,9 & 3.647 & 1,2 \\
\hline Pré-Escola & 316.905 & 251.263 & 79,3 & 57.225 & 18,1 & 8.417 & 2,7 \\
\hline EF - Anos Iniciais & 745.893 & 573.389 & 76,9 & 147.968 & 19,8 & 24.536 & 3,3 \\
\hline EF - Anos Finais & 697.026 & 423.904 & 60,8 & 204.519 & 29,3 & 68.603 & 9,8 \\
\hline Ensino Médio & 513.403 & 301.245 & 58,7 & 151.467 & 29,5 & 60.691 & 11,8 \\
\hline Educação Profissional & 129.396 & 101.464 & 78,4 & 19.542 & 15,1 & 8.390 & 6,5 \\
\hline Educação Especial & 26.263 & 19.689 & 75 & 5.454 & 20,8 & 1.120 & 4,3 \\
\hline EJA & 244.799 & 134.423 & 54,9 & 77.546 & 31,7 & 32.830 & 13,4 \\
\hline
\end{tabular}

Tabela 2: Docentes na Educação Básica por quantidade de estabelecimentos que lecionam. Fonte: Anuário Brasileiro da Educação Básica (2018, p.112)

Observando a tabela pode-se inferir que há grande desigualdade entre os níveis de ensino no que tange a quantidade de estabelecimentos que os docentes atuam. Percebe-se que essa flexibilidade de acumular mais escolas é maior no ensino 
médio, onde a fragmentação horária é maior do que nos anos iniciais e do que a educação infantil. Isto indica que as disparidades salariais entre os níveis de ensino podem estar diretamente relacionadas ao acúmulo de escolas dos professores que atuam nos anos finais e no ensino médio do que necessariamente à maior remuneração bruta recebida por unidade escolar ou vínculo.

Para além disso, a precarização também ocorre no desgaste e superlotação de turmas. A EAG (2018, p. 21) publicou que entre os países pesquisados, o Brasil segue em destaque com a maior proporção de alunos por professor na educação básica de nível médio, com cerca de 26 estudantes/ professor, com diferença de 13 estudantes por professor na média dos demais países. Já se tratando do nível técnico, denominado pelo estudo de programas profissionais, a proporção brasileira é a metade, com cerca de 13 estudantes/professor compatível com a média observada nos países da OCDE. Como mostra o gráfico 7 abaixo:

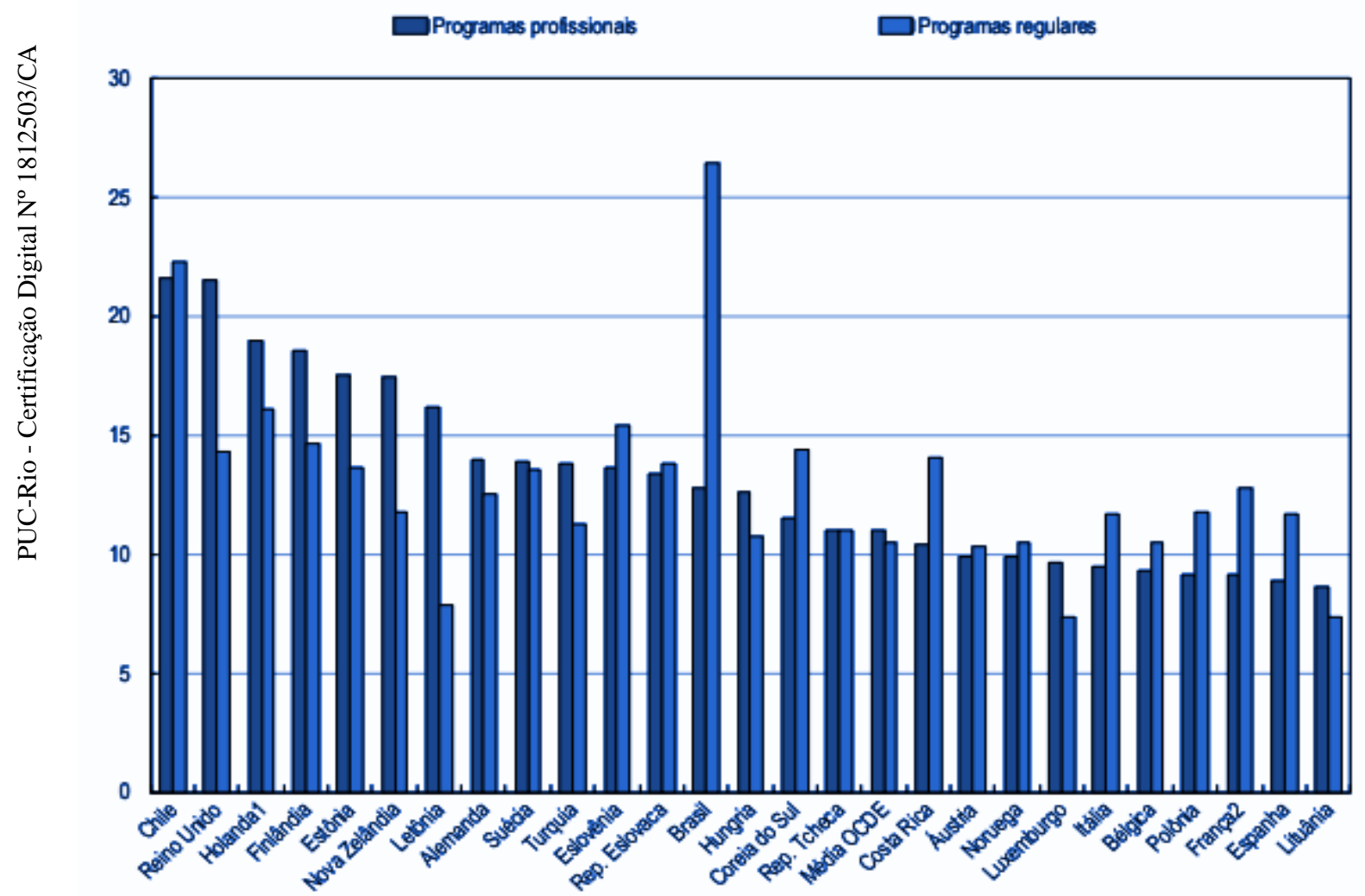

Gráfico 4: Proporção de alunos por equipe escolar (professor e auxiliares) no ensino médio nos países da OCDE. Fonte: Panorama da Educação do Education at a Glance (EAG, 2018, p.22). ${ }^{11}$

${ }^{11}$ Os países são ranqueados em ordem decrescente de proporção de alunos por equipe escolar em programas profissionais do ensino médio. O levantamento abrange somente instituições públicas. 
Segundo o documento, quando se trata do ensino fundamental, a rede privada possui 5 vezes menos o número de alunos da rede pública, porém o relatório não aponta os critérios dessa amostragem e nem gráficos, fazendo uma análise frágil, pois sabese que esta realidade não contempla necessariamente a maioria dessas escolas. Como o indicador de esforço docente (BRASIL, 2014) que aponta a média de alunos por professor não levanta a média de alunos por professor na rede privada, torna-se difícil fazer uma comparação entre as redes.

Desse modo, sabe-se que a combinação de superlotação, acúmulo de escolas e salários baixos favorece o desgaste desses profissionais que se tornam desestimulados e impossibilitados de auxiliar os alunos em suas dificuldades, desempenhar atividades extraclasse, preparar materiais e aulas, entre outros aspectos. Além disso, todos esses dados reforçam a discrepância entre os níveis de ensino.

Tardif \& Lessard (2009, p.41) apontam que esse sentimento de desvalorização se inicia com a profissionalização do ensino nas décadas finais do século XX nos países ocidentais, período no qual diminuem as reformas educacionais ligadas a melhorias destinadas aos alunos em detrimento da ampliação e investimentos em pesquisas ligadas às condições de trabalho do professor, sua formação, profissionalização e formação.

No entanto, o sentimento de inquietação quanto a desvalorização salarial e ao pouco reconhecimento também aumentou, derivadas de diversos problemas que se instalaram no ambiente escolar, por conseguinte, com o desempenho da escola em declínio, a insatisfação por parte da esfera política e da população veio a crescer e pressionar os professores a mostrarem resultados. Isso pode observado com a criação de diversas avaliações nacionais e internacionais para medição da eficiência da escola, pautando inclusive em alguns estados, bônus salarial para os professores conforme desempenho dos alunos nestas provas, o que não evidencia necessariamente um movimento de melhoria do ensino, mas enquadramento e preparação para uma avaliação sob a lógica meritocrática.

Além disso, nos últimos anos percebeu-se uma centralização no desenvolvimento de habilidades e competências ditadas pelos currículos e documentos nacionais, como também preocupação com técnicas e metodologias "inovadoras", isso garantiu maior preocupação com formação continuada e especializada dos professores. 
É possível observar que os relatórios do censo escolar dos últimos cinco anos (20152019), têm dado maior ênfase para a escolaridade dos docentes registrando o abandono das questões trabalhistas. Como vimos, tais questões têm sido apropriadas como objeto de pesquisa e preocupação de órgãos internacionais e de conglomerados privados da educação que periodicamente emitem relatório diagnósticos sobre o trabalho docente. O relatório da pesquisa Talis (2018), também elaborada pela OCDE e aplicada a 48 países, e no Brasil aplicada à 200 escolas dos anos finais do ensino fundamental e 200 de ensino médio, levantando um total de 5.275 professores através de questionário online, mostra que na amostragem, o Brasil possui uma das piores médias de percepção de valorização e isso se agrava no ensino médio, como mostram os gráficos 5 e 6.

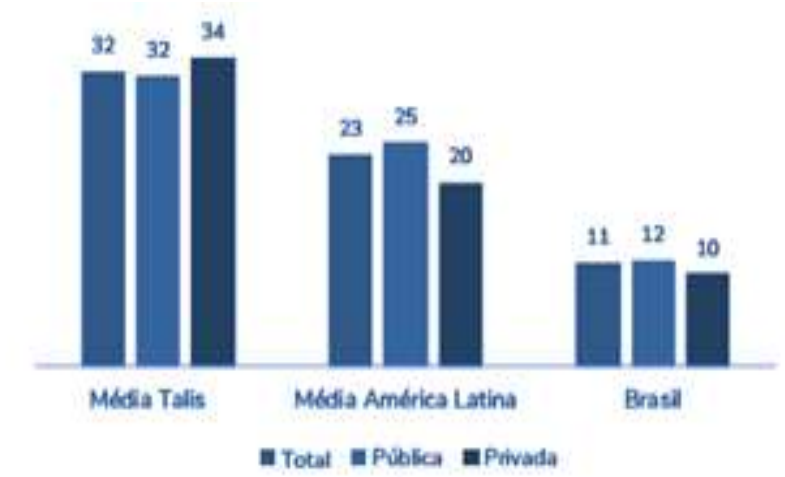

Gráfico 5: percentual de professores que disseram achar que a profissão de professor é valorizada pela sociedade - anos finais ensino fundamental. Fonte: Relatório Nacional Talis (2018, p.17).

Segundo o documento, essa percepção no ensino fundamental está abaixo da média dos países participantes (32\%) e da América Latina (23\%). Enquanto no ensino médio, cerca de $89 \%$ dos professores afirmam que a profissão docente é desvalorizada no Brasil, tanto nas escolas públicas quanto nas privadas. Novamente, o relatório não deixa explícito o que os critérios para avaliar estas perguntas, como também há de se tomar cuidado com a média da América Latina, pois a OCDE não faz esses levantamentos em todos os países latinos, apenas Argentina (Buenos Aires), Brasil e Chile, justamente os países em que as reformas neoliberais na educação tiveram grande abrangência. 


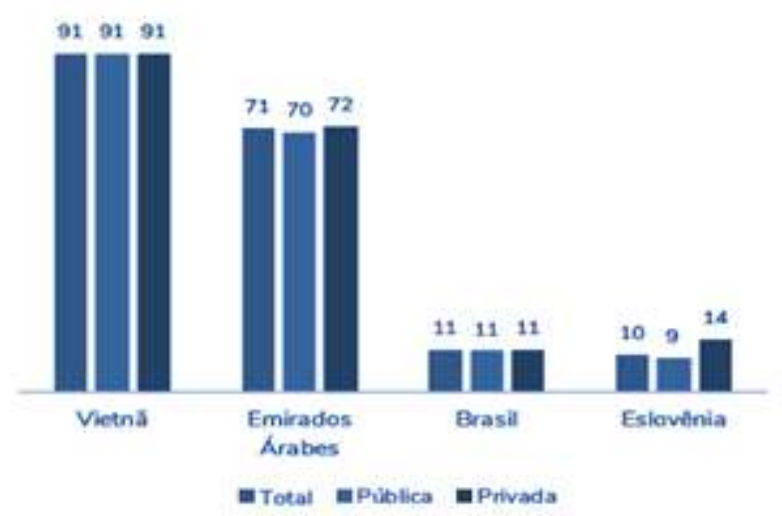

Gráfico 6: percentual de professores que disseram achar que a profissão de professor é valorizada pela sociedade - Ensino Médio. Fonte: Relatório Nacional Talis (2018, p.17)

Desse modo, o que o relatório mostra é que na comparação do Brasil com países da América Latina sobre as vantagens de ser professor, novamente temos uma situação conflitante, estamos abaixo da média dos demais países, tanto em nível fundamental quanto médio. Ainda assim, mesmo com resultados sem parâmetros claros e passíveis de serem relativizados e contestados, há de se preocupar com a situação do país. Obviamente uma pesquisa amostral não tende a evidenciar a realidade em sua totalidade, ainda mais quando o estudo parte de intencionalidades de mercado. Entretanto, indicam que hipoteticamente diante do cenário internacional, a percepção dos professores não é animadora, mas é importante defender que esta preocupação não deve ser levada a fim de guiar políticas públicas de modo a competir com outros países ou na crença de que a melhora dos índices necessariamente solucionará todos os problemas da educação e das condições de trabalho dos professores. Vale ressaltar que o mesmo órgão que organizou a pesquisa pressiona os países a aderir reformas que contribuem para maior precarização dos professores. Então, a pergunta fundamental é quais seriam os objetivos reais destas pesquisas? Utilizar do estigma da categoria para alavancar reformas liberais para educação, escondendo a precarização que ocorre na rede privada e naturalizando as condições atuais de trabalho? Reforçando as velhas narrativas midiáticas que perseguem os professores, como a "a educação é o futuro" ou "a docência é um dom, um ato de amor, etc", mas sem que a devida e necessária valorização dos professores seja tratada como ponto fundamental na discussão sobre a educação do país.

Embora os dados ilustrem uma realidade pouco animadora para a categoria mostrando a realidade de forma mutilada, indicando que somente as políticas locais de cada país determinaram essa precarização, é importante salientar que em outros 
países, inclusive desenvolvidos, como Estados Unidos, eclodiram, nos últimos anos, diversos movimentos acerca das condições de trabalho dos professores.

Vale dizer que a precarização não necessariamente se limita a esfera salarial, embora a busca por maiores salários faça parte de avanços na questão do trabalho, mas a satisfação com o trabalho é tão importante quanto a questão salarial, elas andam combinadas em uma mistura de satisfação e necessidade. Portanto, quando pensamos na esfera da satisfação geralmente nos referimos às práticas sociais do cotidiano e quando falamos da questão salarial, ou seja, do quesito necessidade, esta pode ter influências diretas locais, mas sobretudo, é determinada pelo modo de produção global da sociedade, em quaisquer carreiras. Nesse sentido, assim como qualquer função, o trabalho do professor sofre modificação em seu status e formas de contratação conforme tendências globais de mercado e ideológicas.

ALVES (2005) aponta que o regime Toyotista se apresenta como um novo regime de acumulação flexível, na qual impõe determinadas formas de produção e reprodução social, submetendo esta lógica ao mundo do trabalho privado como também na esfera pública. Este novo momento histórico tratou de capturar a subjetividade do trabalho, ou a consciência do sujeito. Para o autor, este momento inaugura um processo de compressão do corpo e da mente agravando o estranhamento do homem, onde corpo e mente tendem a ser mobilizados para produzir valor. Assim, em vez de expor a crise do trabalho, o Toyotismo tende a instaurar novas determinações na produção.

Segundo o autor, o modelo difundido a partir do Toyotismo procurou capturar o pensamento do trabalho integrando-o nas suas iniciativas intelectuais aos objetivos da produção de mercadoria. É a partir deste gatilho que se desenvolvem a polivalência do trabalhador, verificada frequentemente no trabalho docente, as múltiplas funções, o aprofundamento de cada formação é substituído pelas múltiplas funcionalidades da categoria. Mas como fazer o indivíduo aceitar tal dinamização que corrobora para o desgaste do corpo e mente? A chave para isto está na captura da subjetividade do trabalho vivo, articula-se inicialmente pela contrapartida salarial e agora pelo medo do poder de consumo.

A categoria subjetividade é problemática, pois pressupõe o 'sujeito autônomo', constituído a partir do processo histórico da modernidade capitalista. Mas como vimos anteriormente, o sujeito não é completamente autônomo nesse modelo de produção. O que significa que estamos diante de um processo histórico-dialético intrinsecamente contraditório: o capitalismo 
em seu devir histórico, como sistema social produtor de mercadorias, constitui (e, ao mesmo tempo, desconstitui) o sujeito humano autônomo (Ibidem, sem paginação).

O autor destaca que a precarização teria duas dimensões essenciais de que complementam: a primeira seria a precarização salarial, que se refere a debilidade dos sistemas de contrato, de remuneração, das jornadas de trabalho sobretudo derivadas das mudanças tecnológicas, e segundo, na implementação de uma gestão mais flexível, como a precarização subjetiva, que corroboram para os adoecimentos, os impactos nas individualidades pessoais. Para Tavares (2004), essa flexibilização do sistema Toyotista relaciona-se diretamente ao desemprego e é claramente evidenciado no trabalho informal, nas quais as grandes organizações financeiras mundiais declaram tal problema como "efeitos colaterais indesejáveis". Tavares (2004) aponta que as antigas formas de trabalho como as pequenas empresas, o trabalho domiciliar, as cooperativas estão vivenciando um forte desemprego estrutural. $\mathrm{O}$ advento da educação à distância também inaugura esse momento da educação brasileira. O fascínio pela técnica fez ludibriar a propagação desse modelo em todas as instituições, mesmo aquelas que cumprem papel importante na socialização humana, como a escola, em detrimento de poucos que lucram com esse sistema, colocando centenas de alunos por professores em uma plataforma $\mathrm{EaD}$.

A necessidade da velocidade tornou-se uma regra. Em contrapartida, se por um lado portas do trabalho formal se fecham para muitos mediante essas mudanças, por outro lado a porta para o trabalho informal se amplia rapidamente. Na área educação temos a disseminação de cursos preparatórios e escolas privadas contratando sem vínculos empregatícios. Na área pública, ampliam-se contratos temporários sem que direitos como férias, décimo terceiro e outros benefícios adicionais estejam garantidos. Há casos em que não se respeita nem o cumprimento do prazo de contrato, submetendo professores à instabilidade diante da política local, muitas vezes relacionando as velhas práticas de clientelismo e curral eleitoral com indicação para cargos públicos praticado em prefeituras e estados.

A uberização dos trabalhadores juntamente com a narrativa de inovação e modernidade faz todo esse processo parecer uma condição da evolução humana. O ser humano torna-se sujeitado ao mundo tecnológico que criou, o que Santos (2006) aponta como a técnica como uma finalidade. 
Embora se estabeleça uma relação discriminada e pejorativa diante do trabalho formal, a informalidade não cumpre um papel secundário ao capital. Pelo contrário, ela insere os indivíduos excluídos garantindo-lhes sobrevivência, uma vez que se fundamentam no baixo custo. E por outro lado, atende aos interesses do capital, como moeda de circulação de bens, ou seja, não se trata de uma exclusão do trabalhador, mas de outro tipo de inclusão que se estabelece na instabilidade e na ausência das garantias que outrora em tempos de precarização fábris, ainda se verificava a ocorrência de trabalhadores formais.

Standing (2014) afirma que a informalidade é a principal característica da precarização em tempos neoliberais. Ele conta que o termo precariado surgiu no contexto toyotista japonês para definir os trabalhadores sazonais. Hoje refere-se aos trabalhadores casuais, freelancers, temporários. As garantias sucumbiram juntamente com o antigo modelo rígido laboral. O que se tem hoje é grande fluidez, não se sabe mais o nome do chefe, ou como organizar os sindicatos diante de transformações aceleradas. Para aqueles que detém funções técnicas e desejam maior "autonomia" o CNPJ se sobrepôs ao CPF. São pessoas que não detém o domínio de seu próprio trabalho, e embora possuam nível de educação formal avançado acabam aceitando empregos abaixo do status ou rendimento mínimo por se encontrarem sem opções (Ibidem, 2014, p. 27).

São os cidadãos sem cidadania, uma vez que seus direitos são constantemente sucumbidos. Sendo assim, ele define o precariado como aquele que não possui garantias legais tornando-se informal, são os chamados subempregados. Outro precariado é aquele que se sente desvalorizado em sua remuneração diante de outras categorias de mesmo nível de formação ou de trabalho similar. São os trabalhadores de meio período, ou seja, aqueles que acumulam menos de $30 \mathrm{~h}$ semanais, que acabam, muitas vezes trabalhando mais que os demais, no tempo vago acabam arrumando outros trabalhos, geralmente informais, para complementar a renda. O autor conta que esses empregos de meio período ajudaram na ocultação do desemprego estrutural e na expansão dos subempregos.

Outra categoria seria os "empreiteiros independentes", aqueles que parecem livres, donos de seu tempo, mas prestam serviços terceirizados a uma determinada empresa. Outro grupo são os telefonistas das centrais de atendimento, inúmeros trabalhadores anônimos que cumprem repetidamente um trabalho oral alienado. E por fim, ele inclui os estagiários, que às vezes realizam trabalhos dos profissionais 
da área por um valor muito inferior de remuneração sob o argumento de inclusão, aprendizagem para o mercado de trabalho. Ou no caso das empresas informatizadas, contratam estagiários para esconder o desemprego (STANDING, 2014)

Para o autor, esse processo gera problemas de ordem física e psicológica para o indivíduo, onde ele se sente ansioso, desmotivado, amedrontado, estressado, com raiva, inseguro por não possuir certeza de trabalho, prazer curto com o trabalho, incapacidade de pensar a longo prazo por conta da aceleração impostas pelas tecnologias, pouco estímulo à reflexão, distorção da capacidade e concentração já que o ambiente eletrônico encoraja a realização de multitarefas, descrédito em si mesmo e baixa prospecção de projetar uma carreira futura, dificuldade de confiar em outros indivíduos por conta da competição, relações humanas pouco consistentes, entre outros. Segundo ele, isso afeta diretamente a empatia humana e uma boa sociedade, porque o medo do fracasso e a competição negam a empatia. Essa precarização também tem efeitos no que se diz profissionalização, pois essas pessoas raramente conseguem se especializar, não conseguem avançar em suas habilidades e competências dificultando uma ascensão social (Ibidem, p.39-46) Podemos ver isso no trabalho docente que passou por uma desvalorização coletiva gradual (GOMES \& BRITO, 2014). Os autores reiteram que cada vez mais é cobrado aos professores que ofereçam qualidade de ensino, dentro de um sistema de massa, que se baseia na competitividade, entretanto, os recursos materiais e humanos são cada vez mais precarizados, os baixos salários e o aumento das funções dos professores, contribuem para um esgotamento e uma contradição quanto ao que se é oferecido.

Além disso, a subcontratação não contempla os direitos trabalhistas, assim, percebe-se um processo de reificação sob a lógica empresarial, onde a denominação da categoria professor passa por uma transição para instrutor, na qual põe em dúvida as funções desta categoria. Assim, nota-se uma deterioração das condições subjetivas próprias do trabalho humano, que sobretudo, tratando-se de um trabalho intelectual que visa a autonomia e formação de indivíduos deveria ser consciente. No entanto, estas condições se mostram afetadas em muitos profissionais, de acordo com o grau de objetivação do trabalho na qual aquele indivíduo está inserido. Ao mesmo tempo, quando percebemos o trabalho produtivo o notamos como genuinamente objetivado, imerso em uma fragmentação que compromete a autonomia do trabalhador na execução de suas tarefas, no caso do professor, este 
processo não torna-se reificado na mesma intensidade, pois tratando-se de um trabalho intelectual, permite maior autonomia, uma vez que o professor tem uma gama de metodologias que o deixa livre para abordar conteúdos unilaterais que partem das ações do Estado de maneira transversal, diminuindo a tentativa de controle total do trabalho.

A precarização sob o ponto de vista do desgaste físico é apontada por Foucault (2009) como resultado da objetificação do corpo. Nas escolas, espaços de controle, o indivíduo é treinado para ser controlado. Estes ficam submetidos a níveis de poder como a disciplina, que individualiza o sujeito, o controla e confina, e a segurança, pois exerce o domínio do conjunto de indivíduos sob o território. Nesse sentido, pelo sofrimento que se passa ergue-se um poder do soberano. Segundo o autor, no regime feudal esse controle era maior, no entanto, na mudança das relações sociais, o controle transformou-se, isto remete-se a construção de um biopoder. Para o autor a subordinação corpórea realizada pelas instituições como a escola são meios de normatização da vida cotidiana. Nesse sentido, temos no ambiente escolar claramente o controle dos tempos rígidos que condicionam o trabalho docente, o rigor para cumprimento de atividades que caibam nestas compartimentações do tempo, o que confronta o tempo da vida, o tempo do conhecimento.

Ainda segundo o autor, essa relação de controle e dominação se dá pela passividade dos corpos, o que ele denomina de corpos dóceis. Netto \& Carvalho (2012, p. 37) aponta algumas hipóteses que favorecem atualmente o processo de dominação sob os indivíduos, como o individualismo exacerbado, uma passividade resultante da massificação e alienação, os coletivos oprimidos e excluídos que encontram-se desarticulados e a pouca visibilidade de valores salientada pela dessocialização que assistimos. Diante desse contexto e processos que afetam o trabalho temos o espaço, local onde essas relações são reproduzidas e nele não temos só o que é concreto, mas também todos os fluxos, sobretudo no espaço urbano, como veremos a seguir.

\subsection{A legislação trabalhista e as políticas públicas relacionadas ao trabalho docente}

Quando olhamos para o magistério atual e percebemos como o trabalho flexível, o regime de carga horária diferenciada e parcial fazem parte do seu cotidiano, surge o questionamento de quando isso começou ou pelo menos de quando isso se tornou a regra e permitido legalmente. Fazendo um levantamento de algumas leis e 
políticas que propiciaram chegarmos nessa realidade, encontramos primeiramente o artigo 37 da Constituição Federal de 1988 (BRASIL, 1998), inciso XVI, o qual afirma que a acumulação de cargos públicos é livre somente para a categoria dos professores e profissionais da saúde, definindo o teto de até 80 horas semanais, porém com no máximo dois vínculos públicos e vínculos ilimitados na rede privada. Essa situação ocasionou forte precarização da categoria por encontrar-se submetida ao regime de carga horária desigual e exaustivo, além de transferir para o indivíduo a responsabilidade de obtenção de maiores ganhos individuais.

A justificativa oficial para isso foi de que, na implementação daquela lei, a carência desses profissionais era grande e havia a necessidade de expansão dos sistemas de ensino em um curto período; assim, a fragmentação de carga horária, a princípio, viria a colaborar com a ampliação das escolas pelo país. Isso se estendia para os profissionais da saúde. Assim, essa expansão relacionava-se diretamente à distribuição e à quantidade de professores formados no país.

Havia dois grandes entraves para atender a demanda da época e resolver a alocação de professores, sobretudo no que se refere à educação secundária. O primeiro era a grande quantidade de profissionais que escolheram trabalhar em outras áreas, uma vez que a formação de bacharelado e licenciatura era unificada, com poucas disciplinas distintas. Com salários mais atrativos, em empregos técnicos, aliados à falta de prestígio no magistério, boa parte da mão de obra formada nas faculdades de filosofia, principais instituições formadoras de professores, não priorizava a docência ou não permanecia nela por muito tempo, como aponta Cacete (2014). O segundo problema era em relação à quantidade de faculdades de formação de professores para dar conta de toda demanda nacional, pois, além disso, havia uma desproporção em relação à distribuição dos professores, visto que a maioria e as melhores instituições formadoras concentravam-se no Sudeste, deixando outras regiões em situação de carência de profissional. O problema só não foi sentido com maior intensidade porque havia um sistema de adaptação dos diplomas de cursos superiores profissionais, como engenharia e direito, mediante complementação pedagógica e exames de suficiência, explica a autora. Algo que existe até hoje com o nome de "complementação pedagógica" e vem aumentando diante das crises conjuntural e estrutural que afetam essas e outras profissões.

A autora também conta que foi através da expansão das redes de ensino privadas, nas décadas de 1960 e 1970, influenciada pelo ideário de uma educação que buscava 
atender às necessidades do desenvolvimento a partir da pressão feita por instituições internacionais como a UNESCO, que se deu a expansão da formação de professores secundários e a efetivação da profissionalização da categoria. Segundo ela, o advento de licenciaturas polivalentes e curtas, permitidas a partir da LDB de 1971, também contribuiu com essa expansão.

No entanto, isso não significou uma formação adequada desses profissionais, pelo contrário, as críticas à preparação do professor secundário nas faculdades de filosofia aumentaram. A autora aponta que essas críticas se estendiam tanto para o setor público quanto privado, embora tivessem estabelecido uma grande diferenciação entre essas instituições relacionada à qualidade acadêmica e ao público a quem atendiam.

Em relação a essa formação de professores, Cacete (2014) explica que o processo se deu com a retirada do monopólio dos grupos confessionais, principais formadores, que relacionam a formação docente à mera vocação e eram criticados pela qualidade oferecida, ampliando assim o ensino superior privado. Foi através da acumulação criada nesse período, com a difusão das licenciaturas que exigiam um baixo investimento, que conseguiram, em um segundo momento, com capital suficiente, abandonar os cursos de licenciatura e oferecer novos cursos, que exigiam maiores investimentos, mas possuíam garantias de maior rentabilidade, fazendo da demanda de formação de professores uma mola propulsora para seu crescimento. E assim tornaram-se grandes universidades fundidas com capital financeiro, fazendo da oferta de cursos superiores um lucrativo empreendimento.

Algo que recentemente resultou na transformação de parte das licenciaturas em cursos à distância, como também aumentou a número de licenciaturas desregulamentadas pelo MEC, acarretando ao mesmo tempo na disseminação do ensino superior e na banalização da profissão, pois tal expansão não significou necessariamente melhorias na qualidade do ensino e garantia de empregabilidade. Pereira (2015) afirma que, entre 1995 e 2007, os cursos de licenciatura tiveram um aumento de 197,1\%. Ele aponta também que entre as dez maiores instituições de ensino superior no país em termos de número de alunos matriculados apenas três são públicas, sendo as cinco primeiras privadas e consideradas "universidadesempresas" ou "de massa", ou seja, possuem mensalidades baixas e um grande número de alunos, e nenhuma delas está entre as melhores do país e hoje são as 
principais instituições formadoras de professores no quesito quantidade. Completa ele:

No Estado de São Paulo, o mais rico da federação, tal proporção chegou, em 2010, a 94\% de instituições e "organizações" de ensino superior privadas, contra $6 \%$ públicas, tendo em vista a oferta de cursos de licenciatura. Em 2011, do total de 30.420 cursos de graduação no Brasil, 7.911, ou seja, 26,0\%, eram licenciaturas. E, em relação a 2010, observa-se uma diminuição de $0,1 \%$ de cursos de formação de professores no país. Nas licenciaturas, verifica-se, também em 2011 em relação a 2010, um decréscimo de $0,2 \%$ de matrículas presenciais nesses cursos. No caso de matrículas em cursos a distância, o crescimento observado equivale a $0,8 \%$ para as licenciaturas. Em números absolutos, tem-se, em 2011, 429.549 matrículas em cursos de licenciatura na modalidade a distância - a maior proporção entre os cursos de graduação no país, ou seja, 43,3\% (BRASIL. INEP, 2013 apud PEREIRA, 2015, p.277).

Embora os dados apontem para uma redução das matrículas nas licenciaturas ocasionadas principalmente pelo aumento do desinteresse na profissão, ainda assim o volume de formandos é elevado. No entanto, o que os resumos técnicos do Censo Escolar (BRASIL, 2018 e 2019) mostram é que essa disseminação de licenciaturas não veio acompanhada de uma melhor redistribuição dos professores no território brasileiro, faltando docentes de determinadas disciplinas e sobrando professores com formação inadequada, sobretudo nas regiões Norte, Nordeste e Centro-Oeste. Já nas regiões Sul e Sudeste ocorreu o contrário; há hoje uma boa oferta de professores, a maioria com formação na área de licenciatura, vide resumo técnico do Censo Escolar (BRASIL, 2018), mas isso não significou um reajuste legal na questão da carga horária, alocando-os em uma só escola; pelo contrário, possibilitou um excedente de profissionais, o que significou o aumento da concorrência, permitiu a redução de salários, ampliou a retirada de direitos sobretudo na rede privada. Demonstrando que o problema da falta de profissionais perante a necessidade de expansão da educação no país, na época em que a lei foi aprovada, não se resolveu com a formação em massa, tampouco com a flexibilização de carga horária.

Pereira (2015) aponta que ainda há uma necessidade de formar professores para sanar o déficit na educação básica, sobretudo em alguns cursos e algumas regiões do país. Há também um número reduzido de graduandos pela quantidade de vagas oferecidas, tanto na rede pública quanto na privada superior, ocasionado por diversos motivos, como a dificuldade de se manter durante o curso, a baixa 
expectativa de renda e os problemas em torno da carreira, ampliando a evasão e agravando a crise educacional atual.

Outra questão que envolve essa lei é que ela permitiu ao longo dos anos diferentes sistemas de carga horária e salários entre os níveis e redes de ensino na rede pública. Para revê-la faz-se necessário o debate sobre a discrepância de salário, condições de trabalho, formação entre professores primários e secundários e a revisão da própria estrutura que está assentada o financiamento e a oferta da educação pública no país. Em outras palavras, a legislação e o financiamento que regula e garante o trabalho docente perpassam por uma discussão da própria estrutura que embasa a tributação existente no federalismo, uma vez que o modo escolhido para gerenciar e custear os serviços públicos se deu de forma descentralizada, o que corroborou com a ampliação das desigualdades regionais, característica marcante do federalismo brasileiro, como aponta Araújo (2012).

$\mathrm{O}$ autor explica que isso ocorre porque o federalismo seria uma característica a nível constitucional e a descentralização é uma escolha política pós-constitucional e que uma estrutura federativa não pode ser entendida como uma condição necessária para políticas de descentralização. apesar das políticas descentralizadoras em governos federativos se mostrarem mais estáveis a longo prazo, já que se tornam superiores as às decisões de cada governo. Contudo, ele aponta que há um propósito no federalismo que é a manutenção da União, mesmo que esse federalismo tenha ocorrido de forma a estabelecer um poder de coerção centralizador, como existe no Brasil, e isso podemos perceber na dependência econômica de certas regiões diante de outras. Completa o autor:

A origem da centralização no Brasil deve ser buscada na desigualdade entre as jurisdições para desempenhar adequadamente funções governativas, pois esta característica deu origem à centralização na União das funções tributárias, de planejamento e de execução de políticas. (ARAÚJO, 2012, p.3)

Segundo ele, o desenvolvimento nacional se deu de modo centralizador diante dos desafios da penetração e integração territorial. Ele afirma que as políticas que temos atualmente objetivam, sobretudo, a redução das desigualdades territoriais por meio de reformas fiscais através da regulação federal, favorecendo, assim, essa centralização do poder.

O autor conta que foi com a Constituição Federal de 1998 que os governos subnacionais obtiveram maior soberania nos gastos públicos e na oferta de serviços, 
através do processo de municipalização. Porém, as decisões de arrecadação tributária, destino dos gastos e execução de políticas públicas ficaram sob a imposição da regulação federal, a qual muitas vezes restringe a autonomia por meio de transferências condicionadas e dificulta a concessão de empréstimos para os governos locais. Além disso, as regras de repasse definidas pelo arcabouço jurídico federal são sempre homogêneas através de alíquotas pré-definidas para arrecadação de impostos, o que engessa a autonomia das esferas subnacionais e as coloca no mesmo patamar.

Assim, quando pensamos nos gastos da educação é necessário levar em conta a estrutura regulatória financeira dessas esferas subnacionais. $\mathrm{O}$ autor aponta que não seria necessária uma centralização para melhoramento dos serviços. O modelo atual de repasses não configura necessariamente um entrave para melhoria dos serviços públicos, pois nas palavras dele "é possível ocorrer uma descentralização físcal, como a estabelecida na Constituição de 1988, e isso ser compatível com um governo central mantendo o poder de decisão sobre as bases tributárias e sobre o perfil das políticas que serão implementadas" [TL1] (ARAÚJO, 2012, p.4).

Ele aponta que o papel redistributivo do governo federal é fundamental para equalização regional e minimização das desigualdades existentes entre as jurisdições no que se refere à receita, o que contribui diretamente com a redução da desigualdade de acesso dos cidadãos a serviços públicos no interior do país. Sem essas transferências, a capacidade dos municípios em oferecer serviços públicos estaria comprometida.

Fazendo um breve levantamento das políticas implementadas no país que sofrem regulação federal, combinadas com a regulação das receitas públicas em comparação a políticas não reguladas, o autor aponta que as primeiras obtiveram maior êxito na redução das desigualdades territoriais e redistributivas, sobretudo no que se refere aos serviços essenciais. Além disso, no país não predomina um federalismo competitivo devido à interferência da União na redução dos desequilíbrios de receita entre as jurisdições (ARAÚJO, 2012), o que é positivo, já que estamos falando de gastos essenciais que determinam melhoria nas condições de vida da população.

Entretanto, é preciso levar em conta a realidade local, objetivando alcançar um sistema tributário mais flexível que não comprometa o orçamento das esferas subnacionais. Quando pensamos na política de financiamento da educação, 
percebemos que a descentralização jogou para os estados e municípios a maior fatia desses gastos diretos, mas também colaborou com a criação de fundos que redistribuem os recursos, como o antigo FUNDEB que sucedeu ao FUNDEF, implementados nas décadas de 2000 e 1990, respectivamente. Nesse sistema mais recente, os governos municipais e estaduais eram obrigados a transferir para União $25 \%$ de suas receitas e tal obrigação [TL2] retornava para o estado e para todos os municípios conforme o número de matrículas da respectiva rede de ensino. Assim, como aponta Araújo (2012), havia uma maior migração de recursos dos estados para os municípios.

Sobre esta questão orçamentária, Gatti \& Barreto (2009) afirmam que boa parte da folha das despesas do Estado refere-se aos gastos com saúde e educação, que, atualmente, se encontram na casa de $6 \%$ do PIB, sendo a maior parte deste montante referente à folha de pagamentos dos profissionais da área. Valor esse que se encontra em contingenciamento como divulgado pelo governo federal no Portal Transparência (BRASIL, 2020).

Evolução das despesas na Educação - Governo Federal

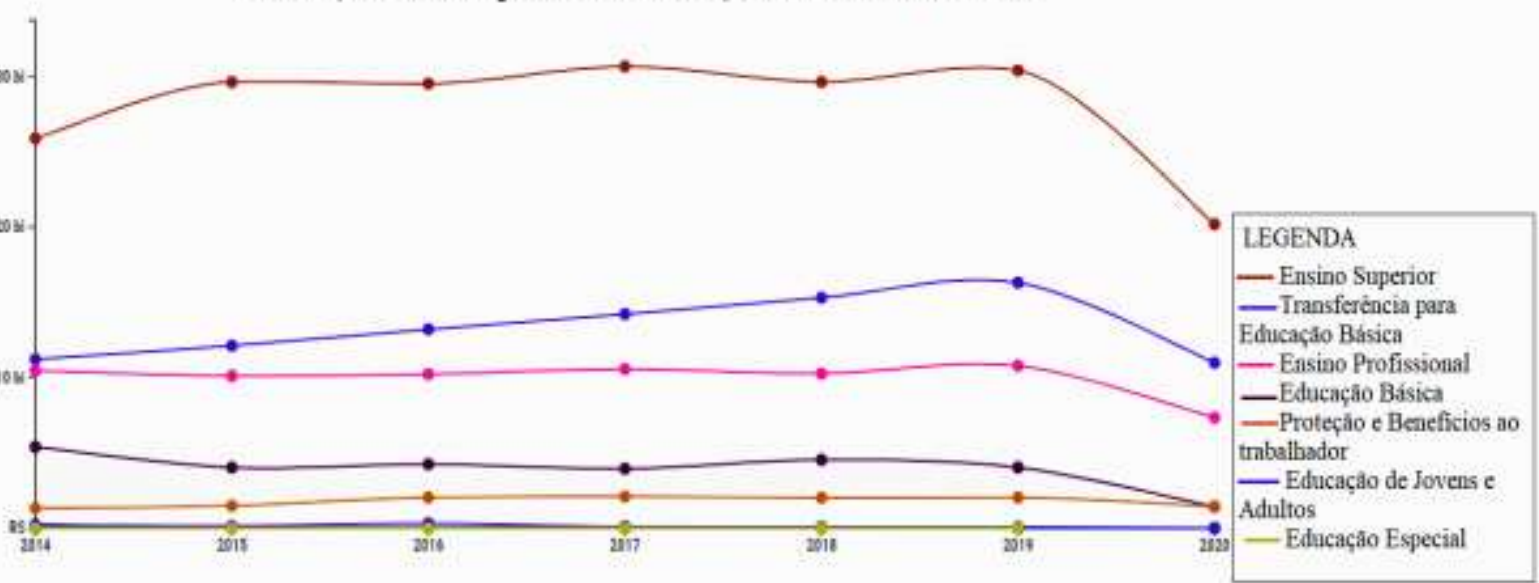

Gráfico 7 - Evolução histórica da execução das despesas na área de atuação de educação. Fonte: adaptado de Portal Transparência (BRASIL, 2020).

Percebe-se que os diversos cortes feitos no ano de 2019 pelo governo federal atingiram sobretudo o ensino superior. Os gastos com proteção e benefícios ao trabalhador não estão na pasta da educação, e sim no MTE vinculado ao Fundo de Amparo ao Trabalhador (FAT). Esse recurso é de natureza contábil-financeira e destina-se ao custeio do seguro-desemprego, do abono salarial e do financiamento de programas de desenvolvimento econômico, como aponta o Portal Transparência (BRASIL, 2020). Ele engloba não só a educação, mas também outras pastas. Nota- 
se que esse gasto se manteve no patamar, garantindo seguridade aos docentes, sobretudo aqueles àqueles que atuam na rede privada.

No que tange à esfera pública, notamos que essa grande redução nos repasses mostrados nas outras categorias deriva-se principalmente da emenda constitucional de 95/16 (BRASIL, 2016), que estabelece um teto de gastos públicos por 20 anos. A alegação para isso é de adequar os gastos federais à capacidade de bancar as despesas. Na prática, os ganhos reais acima da inflação não serão concedidos nos próximos anos. Com o baixo desempenho da economia, o valor diminuiria. Isso poderá impactar diretamente o aumento real no salário dos profissionais da área e a falta de recursos em todas as esferas da educação.

Além disso, como o governo federal é o principal financiador do ensino superior, a medida tem influência direta neste nível da educação, o que já pode ser sentido através dos inúmeros cortes em bolsas, financiamento de pesquisas, manutenção, infraestrutura, abertura de concursos públicos e outros, inclusive afetando a política de formação continuada de professores, algo contraditório, uma vez que a agenda recente do PNE prevê isso como um dos objetivos centrais da educação atual.

A medida pode ter impacto direto na tentativa de aumento e equalização dos salários dos professores. O salário desta categoria está pautado hoje na lei do piso (BRASIL, 2008) que determina uma jornada do magistério de dois terços da carga horária para o desempenho das atividades de interação com os educandos e um terço para planejamento. Destaca-se que essa lei, em seu artigo 5, define piso nacional para a categoria, bem como estabelece a obrigatoriedade de reajustes anuais. Segundo dados do MEC divulgados pela CNTE (2016), cerca de 14 estados e $45 \%$ dos municípios (2.533) do país não pagam o piso.

É importante ressaltar que, além dessa lei, o governo também sancionou o PNE, através da Lei 13.005/2014, propondo vinte metas a serem alcançadas até 2024. O plano tem vigência de dez anos e nele se estabelecem as metas 17, 18 e 20:

Meta 17: valorizar os (as) profissionais do magistério das redes públicas de educação básica de forma a equiparar seu rendimento médio ao dos (as) demais profissionais com escolaridade equivalente, até o final do sexto ano de vigência deste PNE. Meta 18: assegurar, no prazo de 2 (dois) anos, a existência de planos de Carreira para os (as) profissionais da educação básica e superior pública de todos os sistemas de ensino e, para o plano de Carreira dos (as) profissionais da educação básica pública, tomar como referência o piso salarial nacional profissional, definido em lei 
federal, nos termos do inciso VIII do art. 206 da Constituição Federal. Meta 20: ampliar o investimento público em educação pública de forma a atingir, no mínimo, o patamar de $7 \%$ (sete por cento) do Produto Interno Bruto - PIB do País no $5^{\circ}$ (quinto) ano de vigência desta Lei e, no mínimo, o equivalente a $10 \%$ (dez por cento) do PIB ao final do decênio. (BRASIL, 2014, acesso em agosto de 2020)

Como falado, boa parte dos municípios e estados alegam não possuir receitas para arcar com tais custos, comprometendo o cumprimento dessas metas; nesse sentido, vale reforçar a importância do FUNDEB, que destina até $70 \%$ dos recursos para pagamento de salários, como aponta o site do Senado (BRASIL, 2020).

O antigo FUNDEB teve vigência de 14 anos, tendo seu início em 2007, e será encerrado ao final deste ano (2020), entrando em vigor no próximo ano (2021) o novo fundo que foi aprovado em julho, sob uma atmosfera de grande pressão do governo atual para a sua extinção. Vale destacar como principais mudanças: a sua fixação como um fundo permanente e o aumento progressivo da participação percentual da União de 10 para $23 \%$ até 2016, reduzindo assim a participação de estados e municípios que era cerca de $90 \%$ sob o valor total. Essa tendência não é uma novidade; de 2007 a 2009 a contribuição da participação percentual da União saltou de 1\% para 7\%, como aponta Araújo (2012). Embora mostre aumento na porcentagem de participação, a lei do teto de gastos e as medidas de austeridades implementadas nos últimos dois anos revelam que não houve aumento significativo em termos reais, ou seja, as esferas subnacionais reduziram seus repasses, mas não obtiveram um montante maior do que já era investido, pelo contrário, já sentem os impactos dessa emenda constitucional na execução e oferta dos serviços como, por exemplo, a redução de concursos públicos.

No contexto atual de cortes orçamentários, o fundo possui uma importância de garantir a permanência dos recursos na educação, pois ele é distribuído com base nos gastos por aluno da rede pública, ou por redistribuição com base no número de matrículas de cada ente federado, que hoje é cerca de $\mathrm{R} \$ 3.600,00$ anual e chegará a $\mathrm{R} \$ 5.500,00$ nos próximos cinco anos, como prevê o site do Senado Federal (2020). Segundo essa fonte, sem o fundo os valores mínimos de aplicação em educação ficariam em torno de $\mathrm{R} \$ 500$ por aluno/ano nos municípios mais pobres do Brasil. O site aponta que, atualmente, $40 \%$ de todo o investimento no ensino 
básico é responsável por no mínimo 50\% do orçamento anual disponível para cada aluno em mais de $85 \%$ dos municípios brasileiros.

No entanto, o perigo consiste na influência de grandes empresas privadas na elaboração dos requisitos e cálculos do fundo, como foi percebido na campanha do Novo Fundeb através de estudos elaborados pelo Todos pela Educação, uma ONG financiada por grandes empresas do setor educacional que elabora estudos e faz constante monitoramento da educação no país, influenciando, além dessa Organização, outras pautas importantes aprovadas recentemente, como a Reforma do Ensino Médio e a BNCC.

A base do cálculo para distribuição do fundo teve forte influência dessa organização que incorporou neste novo modelo o chamado Custo Aluno Qualidade (CAQ), uma espécie de parâmetro de financiamento educacional, previsto no PNE. Esse parâmetro destinará um montante maior ou menor do fundo de acordo com a formação continuada dos professores e a qualidade da infraestrutura escolar, como acesso à internet, aos banheiros, à quadra de esportes, aos laboratórios e à biblioteca, não só em escolas públicas, mas também em escolas comunitárias, confessionais ou filantrópicas, alcançando a educação infantil que é o segmento de menor oferta na rede pública nacional (BRASIL, 2020). Assim, diversos estados e municípios que não cumpram esses requisitos terão seu montante do fundo reduzido.

Esse parâmetro tende a reforçar a valorização das avaliações externas que medem a qualidade da educação em âmbito nacional, utilizando os resultados para estabelecer padrões de qualidade e fomentar a competitividade entre as unidades escolares e professores, aprofundando a lógica de empresarial no serviço público.

Obviamente isso não soa como novidade, já que a lógica neoliberal na educação vem sendo empregada gradualmente através de leis e pautas que escondem uma cartilha vinda de institucionais internacionais como a OCDE, onde a prioridade é obter uma educação competitiva. Os holofotes viraram-se para forma, gestão, títulos e estrutura e colocaram como segundo plano o conteúdo, a qualidade e as condições de trabalho dos docentes. Isso também pode ser notado ao ler os resumos técnicos do Censo Escolar que focam na infraestrutura, no perfil do aluno e na formação dos professores. O único censo escolar docente foi realizado em 2004 e o último relatório do MEC sobre os professores da educação básica foi feito em 2007 denominado de "Estudo exploratório sobre o professor brasileiro", realizado com 
base no censo escolar do referido ano e para subsidiar as metas propostas pelo PDE, que, segundo o documento oficial:

"define uma agenda de fortalecimento da educação básica, com metas a serem alcançadas, pautada na formação de docentes, no piso salarial nacional dos professores e em novos instrumentos de financiamento, avaliação e responsabilização das escolas e demais agentes públicos” (BRASIL, 2007, p.13).

Um dos entraves desse parâmetro de distribuição é a disparidade existente no país, pois há diversas questões a se considerar como, por exemplo, a concentração das universidades e cursos de pós-graduação nas regiões metropolitanas e em certas regiões do país, o que dificulta a formação continuada dos docentes em regiões interioranas.

Vale ressaltar que no antigo FUNDEB, cujo parâmetro era a distribuição dos recursos por matrícula, também não foi possível mitigar completamente essa desigualdade, pois em estados populosos, como Rio de Janeiro, Bahia, Minas Gerais e São Paulo, em que a média de alunos por turma e o número de matrículas são altos, obteve-se maior parcela do fundo, porém isso não se refletiu necessariamente em melhorias salariais, pois o piso mínimo não foi cumprido em diversos municípios destes estados.

Embora essa arquitetura do regime de colaboração seja objeto de críticas, pois se mostra incipiente e defasada, uma vez que a distribuição de gastos não é proporcional às receitas, a CNTE (2020) defende que a carreira do magistério se encontra distante de um padrão justo de valorização. Ainda assim, o piso e o FUNDEB tornaram-se instrumentos de valorização profissional e precisam ser respeitados pelos gestores. A maior dificuldade de garantir o cumprimento da lei do piso, por exemplo, consiste na descentralização da fiscalização, pois não existe hoje nenhuma ferramenta unificada para controle dos gastos dos entes federativos, apenas há interferência de alguns tribunais que exercem o papel de cobrança.

Outro ponto a se considerar é a garantia que os fundos trazem, perante eventuais crises econômicas, sejam elas causadas pela guerra fiscal, descentralização das atividades produtivas, migração, fuga de capitais, entre outras causas. Isso pôde ser observado com a crise de 2008, comprometendo o orçamento e a garantia de provimento dos serviços públicos, como aponta o autor.

Segundo Araújo (2012), um ano após essa crise, foi possível observar uma grande queda na arrecadação de receitas. No entanto, o FUNDEB não foi atingido, pois a 
queda das receitas municipais e de transferências constitucionais foram supridas pelo aumento da participação da União, pois se tratava de um fundo em que havia a impossibilidade legal de ocorrer contingenciamento dos recursos destinados à complementação, que eram feitos pelo governo federal. $\mathrm{O}$ autor conta que o peso desta política regulada pela esfera federal incrementou o fundo, o que nas palavras do autor "reforça o enunciado de que estados federativos que concentram autoridade regulatória na União criam mecanismos institucionais que operam na direção da redução das desigualdades.” (ARAÚJO, 2012, p.15).

Políticas desse gênero redistributivas, centradas na regulação federal e com maior participação da União, contribuíram para maior cobertura escolar e melhorias nos indicadores de igualdade social e territorial, sobretudo na região Norte e Nordeste onde há alto índice de municipalização, porém com baixa capacidade de autossustentação. Isso reforça a importância dos recursos federais na redução das desigualdades, fato que deve ser levado em conta na questão da garantia salarial dos docentes e regulação do trabalho.

Apesar dos apontamentos do autor em relação à possibilidade de conciliar o modelo atual fiscal com a ampliação da participação da União, a fim de obter bons resultados e maior equidade, há propostas em discussão que defendem a completa centralização da educação, como o projeto de lei n³37 (BRASIL, 2016) que tramitou no Senado, cujo objetivo seria a federalização da educação como uma medida que poderia universalizar salários, gestão, infraestrutura e possibilitaria redistribuir adequadamente os professores pelo país, porém a proposta não vingou e encontra-se arquivada. Não se pretende aqui aprofundar minuciosamente esse debate, porém é fato que um dos grandes gargalos para realocação dos professores em uma única escola com equiparação salarial ou em um sistema de dedicação exclusiva é a questão orçamentária dos estados e municípios e a descentralização das formas de contratação.

Essa discussão perpassa por diferentes jurisdições e não pode ser decidida de forma arbitrária, já que, com todos os problemas do federalismo, a federalização da educação também pode se mostrar prejudicial à esta categoria, uma vez que não é garantida a melhoria das condições de trabalho. Há uma tendência a pensarmos a respeito disso, visto as condições de salários dos professores que atuam nas escolas federais e que em tese os recursos poderiam ser maiores, melhor destinados e até fiscalizados, mas, ao mesmo tempo, sem a autonomia de gestão que existe, por 
exemplo, nas universidades, o ensino básico poderia tornar-se alvo fácil das deliberações ideológicas de cada governo, tornando-se um dos pontos positivos da descentralização: a possibilidade de outras vertentes olhando para as realidades e necessidades locais, mesmo que de forma limitada.

Quando se fala nos investimentos do estado do Rio de Janeiro, observamos uma tendência de grande redução ao longo dos últimos 20 anos. Além disso, segundo Souza \& Camargo (2017), o estado tem cumprido apenas o mínimo constitucional de $25 \%$ em investimentos, com progressivas reduções ao longo dos últimos 20 anos. Como os municípios dependem dos repasses estaduais para aumentar suas receitas através dos fundos e da redistribuição, então isso impacta não só a educação estadual, mas também as redes municipais. Os autores apontam que o descumprimento do percentual mínimo legal e constitucional aplicado pela MDE tem sido recorrente no Brasil por vários entes federados. Eles apontam que entre 1995 o estado investiu cerca de $2 \%$ a mais do piso estadual de $35 \%$ e em 2015 investiu $26 \%$ a menos do que o mínimo estadual previsto. Os autores mostram que desde 1998 os governos estaduais não têm aplicado o percentual mínimo de cada unidade da federação sob o argumento de que devem seguir o percentual mínimo previsto na Constituição Federal.
Além disso, outros fatores contribuem para a "perda" de recursos na área da educação, tais como: o cancelamento de despesa empenhada de um exercício financeiro para o outro; as limitações das políticas fiscal e tributária; a corrupção dos recursos da educação; a contabilização inadequada de impostos e transferências para aplicar na MDE; a não contabilização das aplicações financeiras dos recursos da educação, sobretudo do Fundeb; o pagamento de despesas que não se enquadram em educação, ou até mesmo em MDE; a ausência ou o pouco controle e acompanhamento social dos recursos da educação; a subordinação do Poder Legislativo ao Poder Executivo; as relações patrimonialistas e clientelista entre os poderes, que, dentre outros motivos, têm dilapidado o erário dos entes federados, sobretudo, por interesses escusos entre o capital privado e a classe política, traço marcante de toda sociedade regida pelo sistema econômico capitalista. (SOUZA \& CAMARGO, 2017, p.214 e 215)

Para além de toda discussão orçamentária, há também a questão do regimento legal previdenciário em torno da categoria. $\mathrm{O}$ artigo 201 da $\mathrm{CF} / 1988$ parágrafo 8 surgiu como uma forma de mascarar o problema da exaustão permitida legalmente, concedendo um benefício previdenciário no qual os professores que lecionam para ensino fundamental e médio teriam cinco anos a menos de trabalho perante os 
demais assalariados. Esse sistema foi o que vigorou até o ano de 2019 e funcionava com regra única para a categoria, independentemente da rede de ensino. Professores com 55 anos e 30 anos de contribuição (homens), e 50 anos de idade e 25 anos de contribuição (mulheres) poderiam se aposentar. Tal resolução surge como forma de mitigar os problemas gerados na exploração dos professores, como desgaste físico, mental, na voz e em outros.

Apesar da garantia do tempo reduzido de aposentadoria, das licenças e dos aumentos salariais incorporados nos últimos anos, através da incorporação de títulos, tempo de trabalho (triênios, quinquênios, decênios) e outros, sobretudo concedidos para professores da rede pública, tais avanços não foram substanciais, vide o aumento dos pedidos de afastamento por problemas de saúde, estresse, sobrecarga, além da desvalorização e desprestígio social, que tornaram a carreira cada vez menos atrativa, esvaziando-se a procura pelos cursos de licenciatura .

O contexto de crise econômica favoreceu drásticos cortes e impactos diretos para os professores que viveram na esfera estadual diversos situação crítica com diversos atrasos salariais em 2016, além da ausência de reajustes e fechamento de escolas, com 232 escolas estaduais fechadas nos últimos oito anos, como aponta Silva (2019). Completa a autora:

No período compreendido entre 2010 e 2018 as matrículas dos anos finais do Ensino Fundamental foram reduzidas em 52,6\% (174.761 matrículas) e as do Ensino Médio em $11,6 \%$ (55.242 matrículas), ou seja, mais de 230 mil alunos deixaram de ser atendidos pela rede estadual (Silva, 2019, p. 4151)

Outro fator percebido, nos últimos anos, foi o fechamento também de turnos noturnos que atendiam sobretudo estudantes da Educação de Jovens e Adultos. Sem contar o que ocorre em áreas rurais, onde a carência de professores e até a dificuldade de ordenamento de turnos e turmas fez com que se optasse historicamente pelo desmonte das escolas do que a busca por soluções.

Esse fechamento de turmas e escolas em determinados bairros agrava a questão da superlotação e ocasiona maior deslocamento de alunos, acarretando maior evasão, realocação de professores para outros municípios agravando a questão da mobilidade, onde estes são alocados em unidades escolares mais distantes de suas casas. Além da incerteza em relação à efetivação da matrícula, como aponta o site da Alerj (2019, acesso em agosto de 2020), afirmando que em 2019 cerca de 20 mil 
alunos ficaram fora da escola por falta de vagas nas escolas estaduais, há o déficit de 101 mil aulas que deixavam de ser dadas por falta de professores. A solução apontada pelo então secretário da educação foi de inaugurar cerca de 45 escolas, número inferior às escolas fechadas, causando uma reorganização espacial que não necessariamente atenderia à maior facilidade de acesso de alunos e professores, podendo favorecer o desvio de verbas em obras públicas, como historicamente ocorre no estado, em um momento em que encontra-se em situação de debilidade das contas e, por isso, necessitando de recursos, cujo valor poderia ser empregado em melhorias das escolas já existentes ou das condições de trabalho dos profissionais da área. E com a pandemia da COVID-19 as aulas remotas ou híbridas também foram apontadas como forma de tampar ou mascarar este problema, algo que poderá permanecer após este período, uma vez que não seriam necessários novos docentes para cobrir a demanda atual da rede e continuaria cumprindo os objetivos das políticas neoliberais de enxugamento e sucateamento da educação pública. Percebe-se também que, com essas medidas, a redução do número de alunos por turma ficará inviabilizada nos próximos anos.

Silva (2019) aponta, como impacto direto dessa política de fechamento de escolas, a redução de postos de trabalho. Destaca ela:

Entre 2010 e 2018, o número de docentes da SEEDUC sofreu uma queda de $18,9 \%$, o que equivale a quase 10 mil postos de trabalho a menos. Mesmo com essa grande redução do número de professores, contraditoriamente, nos últimos anos têm sido comum os docentes dividirem sua carga horária em várias escolas, em diferentes disciplinas e em mais de um município, porque a medida que as turmas e turnos são reduzidos ou as escolas são fechadas, a quantidade de professores lotados naquelas unidades acaba excedente. (SILVA, 2019, p. 4153)

Mesmo com esta enorme carência, em março de 2020, a SEEDUC divulgou a abertura de apenas 827 vagas. No lugar de abertura de concurso, o estado optou pela contratação temporária e pela ampliação das horas extras dos professores que já atuam na rede, mediante pagamento da GLP (Gratificação por Lotação Prioritária) (SEEDUC, 2020), podendo o professor efetivo escolher dobrar seu tempo na escola, mesmo que atue em outra área de conhecimento.

Esse benefício acaba sendo satisfatório para o estado que se exima de aumentar a quantidade de funcionários públicos. No entanto, interfere na qualidade do ensino, uma vez que nem sempre os professores GLP são capacitados para lecionar nas áreas que lhes são designadas. Além da própria exaustão devido ao acúmulo de 
turmas e escolas, para se evitar o deslocamento interescolas da mesma rede, muitos optam por essa prática, para exercerem regime de mais horas em uma única escola. Outra legislação importante aprovada em 2017 dentro de um pacote de medidas referentes à reforma trabalhista se refere à terceirização das atividades-fins e à ausência de pessoalidade e subordinação - súmula 331 do TST, lei 13.429/17 (BRASIL, 2017). Antes dessa reforma, a lei permitia apenas a terceirização de atividade-meio, ou seja, atividades que não são essenciais ao objeto principal da empresa ou do órgão público, porém são necessárias para o seu funcionamento. Antes dessa lei era comum encontrar, em empresas públicas e privadas, serviços como o de alimentação, limpeza, segurança, terceirizados. Com a criação da súmula em 2017, a terceirização passa a ser irrestrita, abrangendo também as atividadesfins, ou seja, aquelas que são atribuídas aos objetivos da pessoa jurídica. Em qualquer atividade, a empresa pode contratar um serviço por meio de outra empresa intermediária (interposta) que funciona como mediadora entre a mão-de-obra e a empresa tomadora de serviços, através de contrato. Este trabalhador não é empregado da empresa que utiliza seu serviço, e sim dessa empresa contratada que muitas vezes subordina este trabalhador à uma remuneração inferior ao trabalhador não terceirizado. A empresa, portanto, transfere para o trabalhador os riscos, desobrigando-se de ter que arcar com os direitos trabalhistas (ANTUNES \& DRUCK, 2014).

Os autores apontam que a terceirização institucionaliza a rotatividade da força de trabalho e, sem garantias legais, aumenta-se o número de processos e o adoecimento. Além disso, muitos trabalhadores se sentem discriminados e inferiores perante os demais, são postos como trabalhadores de segunda categoria. Assim, acentua-se a concorrência entre trabalhadores e sindicatos, pulveriza-se a organização sindical, fragmentando a identidade coletiva, expande-se a alienação e a desvalorização humana, ampliando a vulnerabilidade de tais pessoas. Afirmam os autores:

No plano do mercado de trabalho, no qual se estabelecem as relações de compra e venda da força de trabalho, as formas de inserção, os tipos de contrato, os níveis salariais e as jornadas de trabalho, definidos por legislação ou negociação, expressam um recrudescimento da mercantilização: o capital reafirma a força de trabalho como mercadoria, subordinando os trabalhadores a uma lógica em que a flexibilidade, o descarte e superfluidade são fatores determinantes para um grau de instabilidade e insegurança no trabalho, como nunca antes alcançado. Assim, a 
terceirização assume a centralidade na estratégia patronal, já que suas diversas modalidades (tais como cooperativas, pejotização, organizações não governamentais, além das redes de subcontratação) caracterizam "contratos", ou formas de compra e venda da força de trabalho, em que as relações sociais entre capital ou trabalho são disfarçadas ou travestidas de relações interempresas/instituições, além de estabelecer contratos por tempo determinado, flexíveis, de acordo com os ritmos produtivos das empresas contratantes e às quase sempre imprevisíveis oscilações de mercado que desestruturam o trabalho, seu tempo e até mesmo sua sobrevivência. (ANTUNES \& DRUCK, 2014, p.17)

Como resultado temos a ampliação da participação da esfera privada na oferta de serviços entre trabalhadores sem vínculo empregatício e a instituição que irá prestar o serviço. Isso já ocorre em diversas áreas do setor público, inclusive na educação, no entanto, com essa decisão legal aprovada na reforma trabalhista de 2017, municípios e estados ficam isentos de ter que realizar contratação direta do profissional ou realizar concursos, podendo terceirizar serviços importantes, como a docência. Assim, estamos diante de um futuro próximo que poderemos encontrar docentes recebendo menos e sem vínculo empregatício direto com a escola, trabalhando lado a lado de outro que possui as mesmas funções e a mesma carga horária, porém recebendo mais e tendo todos os seus direitos garantidos.

É importante ressaltar que esse tipo de regime trabalhista é diferente da contratação temporária que é feita entre a empresa ou instituição diretamente com o empregado, ou podendo ser através de contrato ou CLT, com ou sem prazo determinado para rescisão. Algumas redes municipais e estaduais já adotam esse tipo de contrato.

Para Antunes (2020), a experimentação que ocorre hoje nos laboratórios do capital caminha para criar uma classe trabalhadora totalmente desprovida de quaisquer direitos. A carteira verde e amarela criada no último governo simboliza fortemente esse momento e mostra um cenário desanimador para um futuro recente.

Atualmente, está em curso a implementação de algumas reformas que afetarão duramente os docentes nos próximos anos, sobretudo os recém-formados, tanto os que atuam na rede privada quanto aqueles que atuarão na rede pública. Três medidas merecem destaque: a MP 905/19, conhecida como carteira de trabalho verde e amarela; (CTVA), a Emenda Constitucional para a Reforma Administrativa; e a Reforma Trabalhista de 2017 (Lei ${ }^{\circ}$ 13.467), todas propostas pelos governos Jair Bolsonaro e Michel Temer, entre 2017 e 2020. 
A primeira medida propõe a flexibilização do pagamento de direitos trabalhistas e reduz as contribuições sociais sob a alegação de estimular a contratação de jovens de 18 a 29 anos e trabalhadores acima de 55 anos que estejam desempregados há pelo menos 12 meses, além de trabalhadores rurais. A medida determina um teto de pagamento de um salário-mínimo e meio e com contratos de 24 meses podendo ser posteriormente renovados. Não obstante, isenta empregadores de pagar a contribuição previdenciária e outras taxas. Sem contar que o trabalhador demitido sem justa causa não terá direito à metade do salário como acontece com a CLT. Altera o descanso obrigatório aos domingos para qualquer dia na semana. Também reduz a contribuição adicional de periculosidade de $30 \%$ para $5 \%$ do salário do empregado que é exposto permanentemente à essa condição. E aumenta a jornada de trabalho de algumas categorias.

Essa medida poderá ser aplicada de 20 a $25 \%$ dos trabalhadores, dependendo do tamanho da empresa. Na prática, nota-se claramente que se trata de uma política falaciosa, pois a retirada de direitos não implicará no aumento das contratações, pelo contrário, será um alívio para o bolso dos empresários, gerando grande economia nos encargos. Desse modo, tem-se uma medida que "legaliza" a informalidade, uma vez que se trata de empregos com o mínimo de garantias sociais.

Já a segunda medida terá impacto nos futuros servidores, atingindo principalmente os professores que correspondem a uma fatia significativa dos funcionários públicos. Entre as diversas mudanças pontuadas no documento, a mais impactante é o fim da estabilidade de funcionários públicos, mas a medida só valerá para aqueles que não estão classificados como carreira de estado, ou seja, funções cruciais de cunho público e sem correspondência no setor privado ou que exijam maior capacitação e responsabilidade. Assim, isenta militares, parlamentares, juízes, desembargadores, ministros, promotores e procuradores dessa reforma, posicionando nitidamente descaso com as categorias de trabalhadores essenciais para a sociedade.

Além disso, o documento reduz as férias de professores do ensino básico ao superior para até 30 dias anuais sob a justificativa de uniformizar o tratamento aos servidores, colocando tais direitos como privilégios da classe e não como necessidade para que estes profissionais possam executar seu trabalho devidamente, 
uma vez que o desgaste mental, físico e, sobretudo vocal, deveria ser algo a se considerar neste sentido.

Na prática, essas medidas resultarão na fragilização do trabalho, na redução ou fim dos concursos públicos para diversas categorias e no aumento exponencial da terceirização, assim o que era a minoria de trabalhadores poderá ser normalizado na área pública. Isso tudo sem mexer nas categorias que recebem os maiores salários e sem mencionar o principal gasto do governo: a dívida pública, ou seja, a medida não resultará em um impacto positivo para as finanças públicas, pois atingirá diretamente os serviços ofertados à população mais necessitada.

A terceira trata-se da liberalização do trabalho intermitente, em que o contratado aguarda a convocação da empresa e recebe apenas pelas horas trabalhadas. Assim o trabalhador pode estabelecer contrato com diversas empresas ao mesmo tempo, sem receber seguro-desemprego, além de poder prestar serviço para vários empregadores. A princípio parece ser algo positivo, já que sem regularidade dos trabalhadores formais o intermitente trabalharia menos, mas na verdade favorece o aumento da informalidade e maior busca por mais contratos. Isso não é um fenômeno recente, porém a sua legalização o coloca como uma tendência a ser seguida pelas empresas. Assim, a reforma acaba por legalizar o trabalho parcial, o autônomo, a terceirização, entre outros. Podemos ver isso na carreira docente com o aumento do trabalho intermitente, sobretudo àqueles que atuam em cursos preparatórios, os quais muitos não estabelecem nenhum vínculo, como quando o professor aguarda a empresa ligar para dar os chamados aulões ou até mesmo mantém uma regularidade semanal, porém, com o fim de uma turma, o docente é dispensado e fica a aguardar até que outra turma seja aberta. Essa instabilidade gera grande rotatividade de docentes.

A pergunta que se faz diante desse destrutivo contexto é: a quem interessa toda essa espoliação do mundo do trabalho? Percebe-se que estes projetos anunciam o enfraquecimento do Estado, o aumento da fragilidade do servidor e corroboram com a ampliação e lucratividade do setor privado. Isso pode ser percebido não só na educação, mas também no sucateamento da saúde, ocasionando aumento dos custos e crescimento dos planos de saúde. Na educação, nota-se o crescimento dos monopólios educacionais voltados para diversos níveis de renda e públicos, utilizando diversos nomes, porém com um mesmo financiador: o mercado financeiro que dita a lógica de funcionamento da educação voltada para obtenção 
de lucros, através da disputa de fundos públicos, flexibilização das leis trabalhistas e sucateamento do ensino público. Com isso, temos o avanço a passos largos das políticas neoliberais e de grande retrocesso nas conquistas trabalhistas do último século.

A pandemia do COVID-19 também contribuiu para revelar ainda mais a precarização do trabalho docente no Brasil, todavia, como trata-se de um fenômeno recente, ficamos impossibilitados de aprofundar o debate, mas já é notório a falta de políticas voltadas para educação, tanto para alunos quanto para professores, neste contexto. A troca de três ministros da Educação em apenas dois anos, a ausência de ocupação do cargo durante os meses de junho e julho de 2020, as polêmicas envolvendo indicados à vaga e ex-ministros, engendram um contexto crítico no qual se insere a educação hoje e que desmobiliza professores, pairando grande incerteza sobre o futuro da categoria que já se encontra em situação de grande desgaste.

Antunes (2020) afirma que todas essas mudanças fazem parte de um sistema metabólico do capital que é destrutivo e agora está mostrando sua face mais brutal, pois atinge principalmente os pobres e o sul global, sobretudo quando chega às periferias. Esse sistema tem um corpo de classe, não atinge a todos da mesma forma. Quando pensamos nos professores, obviamente estamos falando de uma categoria que sente mais duramente esse processo do que outras carreiras de nível superior voltadas para geração de maiores lucros, mas, ainda assim, encontra-se em situação bastante favorável perante a massa de trabalhadores informais, funções de baixa qualificação e desempregados.

Para o autor, se nada for feito, esse metabolismo poderá gerar a deterioração das formas de trabalho que se assemelham à época da escravidão, com jornadas de trabalho de 16 ou 14 horas por dia e baixíssimas remunerações, ou seja, um retorno ao século XVIII. O que se torna novo é a combinação de um sistema altamente tecnológico com a utilização de uma brutal extração da força de trabalho, gerando uma massa de pessoas sem trabalho e aumentando bastante o trabalho intermitente, ou seja, é um processo engendrado que visa burlar a legislação do trabalho, repaginando a informalidade, aumentando o desemprego e as relações de trabalho degradantes, aponta o autor.

Como vimos, este fenômeno já estava em curso unindo os avanços da tecnologia ao processo de corrosão, devastação da legislação social protetora do trabalho em escala global. Assim, como tempo e espaço são constantemente modificados diante 
da mundialização, temos a explosão de novas modalidades de trabalho (ANTUNES \& DRUCK, 2014), fazendo surgir uma epidemia da terceirização, conforme apontam os autores. Isso é algo que surge nesta última década e que não existia antes no mundo. Antes disso tínhamos as grandes empresas e indústrias monopolistas e pós anos 1970, elas se tornam gradualmente secundárias, dando lugar às empresas tecnológicas que passam a ter maior valor de mercado e extraindo mais valia direta do trabalho. Apresentam o discurso que vendem tecnologia e quando na verdade utilizam da força de trabalho sem garantir os meios para isso.

Esta tendência tem sido reproduzida em todos os setores econômicos e nas diferentes dependências administrativas (pública e privada). O que vemos hoje é a transferência de todo custo para o trabalhador e, com os professores, não foi diferente nem antes ou durante a pandemia, por exemplo, pois já tinham que arcar com custos de deslocamento, alimentação, aperfeiçoamento, material, entre outros, durante a pandemia isto somente se ampliou para os custos de internet, aplicativos e plataformas digitais.

A implementação do home office, por exemplo, não se configura algo inovador, ele reforça, senão piora a questão docente, pois retira tempo de vida e aumenta o tempo de trabalho. Também amplia a terceirização e o desemprego, uma vez que muitas redes de ensino fecham ou unem turmas, colocando nelas muitos alunos por professor, buscando uma economia.

É sabido que ele também gera economia de tempo de deslocamento e que seria fácil e simplista apontá-lo como uma possível solução para a questão da hipermobilidade docente, a ser mostrada mais a frente neste trabalho, já que ele também pode ser sazonal, algumas semanas ou dias em casa outras no trabalho e que em tese a jornada de trabalho deve ser igual aqueles que trabalham presencialmente, além dos direitos em tese serem os mesmos. Mas sabemos que na prática não é necessariamente isto que ocorre e, como aponta Antunes (2020), o maior problema do home office é a individualização, fragmentação e separação das pessoas. Outro problema que ele aponta é que o home office nos tira da sociabilidade e, em qualquer trabalho, há coágulos sociais. Ele quebra a forma de organização sindical. O espaço para lazer e trabalho se misturam; assim os problemas do trabalho adentram os lares e isso é sentido em maior ou menor grau conforme renda, gênero, idade, raça. Por exemplo, as mulheres se sentem mais sobrecarregadas nesse ambiente de dupla função. Sem contar que o home office dilui a distinção do tempo 
de trabalho e não trabalho, sendo comum no caso do professor ter que responder alunos fora do horário ou dia habitual, além de acumular outras tarefas, mostrando que, se houver prolongamento dessa tendência pós-pandemia, poderá se ampliar as jornadas de trabalho sob a cortina da flexibilidade que, na verdade, poderá aprofundar da fragilização da categoria.

Ao mesmo tempo podemos dizer que se há algo que a pandemia revelou foi a suma importância desses trabalhadores e da sociabilidade, sobretudo quando pensamos em uma atividade que envolve interação entre os sujeitos, que necessita de reciprocidade e que é eminentemente presencial, pois o ensino remoto ou à distância fragmenta e individualiza os sujeitos. Para Antunes (2020) o mundo digital sem trabalho humano é absolutamente irrelevante e sem propósito. Não cabe aqui uma discussão crítica sobre as nuances ou os impactos dessa modalidade de ensino, porque sabemos que embora tenha importância como mecanismo capaz de criar maior acessibilidade, vencendo as barreiras da distância e do engessamento do tempo de estudo e trabalho, ela se mostrou extremamente limitada diante da forma que foi implementada e da realidade de inacessibilidade aos meios de comunicação que temos entre as distintas classes sociais e regiões. Contudo, a discussão vai além disso, o que se vê na hibridez do mundo tecnológico e real é a trincheira que se aprofunda entre as pessoas, a dificuldade de se estabelecer relações principalmente com o diferente. Dessa maneira, dilui-se a construção de laços humanos acompanhando a fluidez e efemeridade do mundo conectado que, acompanhados das transformações no mundo do trabalho, podem gerar conhecimentos rasos e ampliar a desvalorização dos professores ou mesmo torná-los dispensáveis em detrimento dos artifícios digitais.

Assim sendo, o autor também afirma que a pandemia também mostrou que os trabalhos não valorizados são aqueles que têm profundo valor humano e societal e os que possuem valor são aqueles que geram lucro. Trata-se de um sistema antissocial do capital que, em sua normalidade, é altamente destrutivo. O sistema de metabolismo do capital hoje só se reproduz destruindo a força humana de trabalho, a natureza de maneira irreversível e a humanidade através de guerras e outras manifestações como visto na pandemia. É um sistema parasitário porque sem o trabalho humano ele não se reproduz (ANTUNES, 2020).

Assim, o autor aponta que o que está diante de nossos olhos não é o fim do trabalho, mas uma nova configuração que coloca trabalhadores em situação de completa 
servidão. Nesse sentido, faz-se urgente pensarmos em formas de contornar o cenário que se desenha para a educação nos próximos anos. Diante desse contexto, a fim de pensarmos formas de frear esse avanço e quem sabe vislumbrar futuramente soluções para tal problema, bem como entender os efeitos espaciais dessa precarização, como os impactos na mobilidade desses trabalhadores, mostrase uma discussão relevante para nos apontar caminhos e metodologias que nos ajudem a compreender a complexidade das questões geradas a partir das relações de trabalho. 


\section{Capítulo 3. A mobilidade espacial enquanto categoria de análise}

Diga-me a que velocidade que te moves e te direi quem és.

(ILLICH, 2005, p.52 apud BARBOSA, 2016, p.49)

Como vimos, a vulnerabilidade em relação as formas de contratação, os baixos salários e a instabilidade no trabalho têm levado a força de trabalho a buscar outras fontes de renda e isso reverbera sobre a dinâmica urbana, especificamente, em relação aos fluxos nas metrópoles e regiões metropolitanas. Assim, a mobilidade conecta espacialmente as atividades econômicas, o acesso ao trabalho, ao lazer, entre outros.

A mobilidade é capacidade de se locomover e envolve a acessibilidade de proporcionar às pessoas a chegarem aos seus destinos. Há uma disputa atualmente em relação a essa nomenclatura, pois é utilizada para os mais diversos fins. A política de mobilidade é regulada pelo Estado, pois é um sistema coletivo e que exige um planejamento central. Assim, nossos horários, nossos compromissos, nossas idas e vindas convivem com a cidade.

Ao mesmo tempo, outros processos cruzam com a mobilidade e são tratados de forma separada fazendo coexistir na metrópole políticas que não se integram. A discussão é técnica, mas ao mesmo tempo é mais ampla, social e política.

\footnotetext{
Retornando à manifestação da liberdade no ato de empreender o movimento migratório, do ponto de vista marxista, a dupla dimensão da liberdade sob o domínio do capital se manifesta da seguinte forma: a primeira, tida como "positiva", é a da livre circulação da força de trabalho; a outra, a liberdade "negativa", se dá em função de estar despossuído dos meios de reprodução, logo livre para circular em busca de compradores de sua força de trabalho, única mercadoria de que dispõem. Para tanto, longe de ser natural, essa mobilidade seria resultado de um longo e conturbado processo histórico (VAINER, 1998). Para Sayad (2000), pensar o processo migratório é pensar o Estado, no caso das migrações internas, sobretudo quando este cobre extensões territoriais continentais. Tratar tecnicamente a discussão sobre o fenômeno migratório seria como tornar técnico um processo social. (OLIVEIRA, 2009, p.20)
}

A crise da mobilidade e do trabalho mostra que é urgente estabelecer relação entre elas e com a nova fase de reestruturação produtiva. A tentativa de solucionar os problemas da mobilidade através do olhar somente para os transportes corrobora 
como uma visão limitada do todo, ou seja, privilegia-se somente o estudo das técnicas e o sobrepõe à natureza dos processos que influem no espaço.

Para Barbosa (2016) a mobilidade teria três dimensões: sociológica, circulação de bens e pessoas e socioespacial, que ao mesmo tempo que incorpora as duas primeiras, busca superá-las para se pensar uma política de cidade. É nesse sentido que decorre esta pesquisa, na tentativa de estabelecer a relação entre os processos que produzem a mobilidade dos professores e contribuir com reflexões para que se possa pensar a mobilidade docente como um fato que necessita ser levado em conta na discussão da precarização do trabalho.

Pensar o problema da mobilidade por outro viés, sobre os processos que ditam seu ritmo e direção nas grandes metrópoles é sim pensar no contexto social de melhoria das condições de vida. A forma de organização do trabalho que predomina hoje gera a precarização da vida e, portanto, uma mobilidade no sentido perverso. A seguir falaremos desses aspectos. Os dados técnicos quantitativos das pesquisas de deslocamento nos ajudam nesse sentido.

\subsection{Elementos para compreensão da mobilidade: definição, tipologia e modelos de análises}

Antes de partirmos para a teorização geográfica, faz-se necessário a diferenciação do termo migração, mobilidade, movimento e circulação. Sabemos que o ato de se mover é uma condição latente no ser humano. A ideia de migração remete muitas vezes à permanência, mudança de localidade (residência, cidade, estado, país), envolve a materialidade, processos de desterritorialização e reterritorialização, que não são necessariamente sucessivos nem ordenados (BRUMES, 2011, p. 24). Quando tratamos os deslocamentos pendulares, alguns autores os enquadram como movimentos migratórios, embora não impliquem a transferência para outro lugar, e sim a ideia de fluxo de pessoas no território. Visitando a bibliografia clássica sobre a Geografia da População, temos BEAUJEU-GARNIER (1980) chamando os movimentos pendulares de "migrações oscilatórias", que ocorrem no cotidiano. Em literaturas estrangeiras, o termo era tratado como commuting ou navettes em francês, ambos simbolizando o deslocamento da população.

Se reconhecermos que, de fato, há enorme número de pessoas envolvidas nesse movimento diário, comumente realizado duas vezes por dia, poderemos restringir o uso do termo 'commuting' 
a movimentos que encerram três características: apreciável extensão, uso de alguns meios de transporte mecânicos e certo grau de convergência (BEAUJEU-GARNIER 1980, p. 292-293)

A própria autora alerta que naquele momento havia poucos conhecimentos sobre o assunto e isso dificultava até mesmo a representação cartográfica desses fluxos. Contemporâneos a ela, como Ravenstein (1980), chamaram de "migrantes temporários". Embora com diferentes nomenclaturas, a essência era a mesma: populações que se deslocavam pelas cidades. Para Becker (2006, p. 323) o termo migração pode ser definido como "mobilidade espacial da população"; seriam, portanto, sinônimos?

A resposta é não, porém possuem a mesma natureza que é o movimento. Conforme a conceituação de Marandola (2011), o movimento ou deslocamento é o processo que leva corpos de A para B. Já a mobilidade é mais ampla, pois é social, envolve estruturas, meios, cultura e significado, envolve lazer, trabalho, compras e as diversas motivações que ocorram no cotidiano. Portanto, ao pensarmos o movimento não podemos separá-lo da mobilidade.

O movimento, portanto, descreve a ideia de um ato de deslocamento que permite que as pessoas se desloquem entre os locais ponto A e ponto B nas discussões abstratas e positivistas da migração). Movimento é o fato geral do deslocamento antes do tipo, estratégias, e das implicações sociais desse movimento serem consideradas. (CRESSWELL, 2006, p.3, tradução da autora)

Ela exprime a característica da vida da urbe atual, inclui também os meios pelos quais a população se desloca, como os diversos tipos de transportes. Na literatura não há muito consenso sobre a terminologia, alguns denominam de migração pendular e outros movimento pendular, com sentidos iguais: a regularidade cotidiana que percorre municípios diferentes ou longas distâncias impulsionadas pelo trabalho ou estudo.

No entanto, o termo mais utilizado nas literaturas recentes ao tratar a questão é a mobilidade pendular, uma vez que a migração remeteria aos movimentos permanentes, assim ficariam excluídos dessa classificação os movimentos sazonais, o nomadismo e os pendulares; por isso optamos por usar o termo mobilidade, uma vez que ele inclui não só o movimento, mas também os fatores externos a ele e que o produziram ou que dele derivam, visto que é a partir dele que podemos entender a metropolização e a extensão da circulação de pessoas em uma determinada área. 
Segundo Cresswell (2006, p.1), no mundo ocidental, a mobilidade tem vários significados que circulam a vida moderna: a mobilidade como progresso, como liberdade, como oportunidade, modernidade, desvio ou resistência.

Como afirma Balbim (2016, p.27), o conceito de mobilidade é amplo e supera a noção de movimentar-se como uma ação isolada, abrange a integração da ação física ou virtual com a posição que os indivíduos ocupam na sociedade. Essa mobilidade pode estar atrelada às escolhas individuais, esperanças, limitações, imposições, mas sempre está em função do espaço onde a vida se concretiza. Em geral, ela está fortemente atrelada ao espaço urbano onde a circulação é condição de diferenciação da cidade e do campo, como apontado por Sorre (1984, p.116 apud Balbim, 2016, p. 26). Para este geógrafo, a circulação é a característica desses espaços nas sociedades modernas. Ela é possível graças ao desenvolvimento do chamado gêneros de vida, que, nas palavras do autor, significa: "a combinação de técnicas empregadas em determinado lugar, por determinada sociedade organizada, para assegurar sua reprodução" (ibidem).

Portanto, essa mobilidade ocorre na dimensão espacial do cotidiano, ou seja, na dimensão do espaço vivido, que se trata do espaço percorrido pelas pessoas. Para Santos (2006), a ampliação dos fluxos tem a ver com o avanço das técnicas na era da globalização que encurtam as distâncias e impõem um novo paradigma. Se antes a relação da difusão global das técnicas era local-local, agora é local-global. A categoria lugar torna-se fundamental para entender as subjetividades que o permeiam e as emoções. É nele que recorremos nossas necessidades existenciais sejam localização, posição, mobilidade, culminando na interação com os objetos e/ou com as pessoas.

Souza (2013, p.36) afirma que o lugar é o abstrato da localidade, dotado de carga simbólica que possui uma imagem conflituosa positiva ou negativa. É o espaço vivido na qual mora e trabalha pessoas cotidianamente. Sua imagem pode ser criada também de fora para dentro com base na vivência, mas esporádica. Para Massey (2008) esse espaço é sempre aberto, contínuo e sempre mutável.

Não apenas a história, mas também o espaço é aberto (...) O espaço jamais poderá ser essa simultaneidade completa, na qual todas as interconexões já tenham sido estabelecidas e no qual todos os lugares já estão ligados a todos os outro. Um espaço, então, que não é nem um recipiente para identidades sempre-já constituídas nem um holismo completamente fechado. É um espaço de resultados imprevisíveis e de ligações ausentes. Para 
que o futuro seja aberto, o espaço também deve sê-lo. (MASSEY, 2008, p.32)

Nesse sentido, a mobilidade ocorre nos espaços da vida; como afirma Marandola, (2011, p. 98) ela tem relação direta com a trama socioespacial das aglomerações urbanas contemporâneas, revelando dinâmicas globais, regionais e locais num mesmo plano. Para além das técnicas, nas quais o conceito muitas vezes é associado aos meios de transportes, ele também envolve a esfera social, na qual geralmente está atrelada ao esgotamento da vida metropolitana, o que o autor chama de esgarçamento da teia social (Ibidem, p.104). Uma vez que os fluxos se tornaram tão intensos que perdemos a ideia de localidade fechada, o que se tem hoje é uma metrópole fragmentada, alienante e espraiada. Os fluxos tornaram-se obrigatórios e suprimem as escolhas individuais, sobretudo no que tange sua relação com o trabalho, e não são computados no esforço e na remuneração docente, por exemplo, apesar de ser obrigatório. Nesse ponto, a ideia de movimentar-se não se refere de fato à mobilidade no sentido positivo da palavra, ou seja, como uma mobilidade que permite ver e conhecer o mundo e o espaço, a mobilidade que se tem hoje nas metrópoles é da supressão, da obrigação. Nesse ponto, completa Balbim:

Uma pessoa pode, por exemplo, considerar que tem baixa ou pouca mobilidade, ainda que seu índice de mobilidade - ou seja, o número de deslocamento por dia -, seja relativamente alto. Essa sensação pode resultar da constância e da repetição dos seus deslocamentos, que, em vez de libertar essa pessoa, a encerram. Ou poderia ser o resultado de baixa renda, que impõe ao sujeito um padrão de deslocamento cotidiano e uma apreensão reduzida do espaço da cidade, o que inviabiliza inclusive sua expectativa de ascensão ou mobilidade social, que - caso se concretizasse geraria mobilidade residencial, nova condição de urbanidade, novas estratégias de deslocamento etc. E é essa a característica que se quer aqui ressaltar, o conceito de mobilidade, além de polissêmico, é sistêmico. (BALBIM, p.27)

Portanto, essa mobilidade sistêmica não envolve apenas os fluxos de um ponto a outro no espaço, mas também o produto desses fluxos, as intencionalidades que o geraram, a mobilidade social ou a imobilidade produzida no espaço urbano. Nesse sentido, Balbim nos ajuda a sistematizar o conceito para melhor apropriação e delimitação do objeto de estudo, dividindo a mobilidade em duas correntes: a mobilidade sob o ponto de vista social que se refere à ascensão de classes, também incluindo a mobilidade profissional - atrelada à mudança de funções no trabalho e a mobilidade do trabalho, quando se refere à escolha individual de onde trabalhar, geralmente tratando-se de uma mesma empresa ou setor. Também temos o outro 
aspecto da mobilidade que é determinada pelos deslocamentos físicos, o que Max Sorre (1955 apud Balbim, 2016, p.28) chama de mobilidade essencial do ser humano. Nela se encontram a locomoção como característica própria do homem, a mobilidade sob a dimensão dos deslocamentos do cotidiano (fluxos pendulares casa-trabalho, por exemplo) e, por fim, a mobilidade sem deslocamento que geralmente se relaciona aos fluxos financeiros, de pessoas, moda, informações, entre outros.

A partir disso, podemos pensar a mobilidade cotidiana ou geográfica, na qual inclui as dimensões temporal e espacial do movimento, divididas em movimento recorrente, na qual se tem o retorno em um curto espaço de tempo ou o oposto com o movimento não recorrente, quando não há retorno breve. Já a dimensão espacial está fundamentada nos deslocamentos internos do espaço vivido, dos deslocamentos para espaços desconhecidos, como migração internacional, regional, temporal e outros (Ibidem, p.29). Sintetiza o autor:

Como resultado, têm-se quatro tipos de mobilidade geográfica. São estes: mobilidade cotidiana (movimentos interno e cíclico); mobilidade residencial (movimentos interno e linear); o turismo, tanto de lazer quanto de negócios, ou até mesmo os deslocamentos para trabalhos sazonais (movimentos externo e cíclico); e as migrações (movimentos externo e linear) (Ibidem, p.29).

Cada um desses tipos estabelece conexões entre si, tanto de causalidade, quanto de incompatibilidade, compatibilidade, complementaridade e outros (Ibidem, p.30). Cresswell (2010) considera que exista não apenas uma mobilidade, mas várias mobilidades e que tal conceito resguarda um paradigma; o primeiro é que qualquer estudo de mobilidade corre o risco de sugerir algo que é (supostamente) imóvel noções como limites e fronteiras, local, território e paisagem - esta concepção, segundo ele, é do passado e não é mais relevante para o mundo dinâmico do século XXI.

Seria um equívoco considerar somente uma das faces da questão, pois até mesmo as "imobilidades" de alguns indivíduos seriam tão importantes quanto "mobilidades" no estudo da mobilidade. O segundo paradigma se refere às diferentes formas pelas quais "novas mobilidades" podem ser lidas, sugerindo que velhos paradigmas foram sobre os imóveis ou sedentários. Ele completa que esta última não se sustenta, pois embora os movimentos estejam no centro de debate da Geografia desde sua criação, estes também aparecem em outras ciências sociais e 
nessas novas mobilidades é que tem surgido a possibilidade de tratar o tema de forma interdisciplinar, estudando os grupos que se deslocam e outras variáveis, como explica o autor:

Se pensarmos em geografia, houve algum número de preocupações subdisciplinares com coisas e pessoas em movimento, variando de sauriano às preocupações com origens e dispersões (Sauer, 1952) através da fixação da ciência espacial modelos de gravidade e teoria da interação espacial (Abler et al, 1971) e noções do espaço plástico (Forer, 1978), abordagens feministas, padrões de mobilidade diários (Hanson e Pratt, 1995; Pickup, 1988). Geografia dos transportes, teoria da migração, tempo geografias, geografias do turismo - a lista é interminável. $\mathrm{O}$ mesmo poderia ser dito da antropologia. Portanto, a pergunta que se coloca é: o que há de novo no paradigma das novas mobilidades? Apesar de todas as advertências acima, há claramente algo de "novo" nas maneiras pelas quais as mobilidades estão sendo abordadas atualmente que as distingue das anteriores e que levavam em conta a movimentação, migração e transporte (para citar apenas três dos modos de mobilidade há muito tempo consideradas). Se a abordagem das "mobilidades" reúne uma variedade diversificada de formas de movimento em escalas que variam do corpo (ou partes do corpo) para o globo. Essas áreas substantivas de pesquisa teriam sido anteriormente separadas por fronteiras disciplinares e subdisciplinares, isso mitigou contra uma compreensão mais holística das mobilidades. (CRESSWELL, 2010, p.12, tradução da autora)

Ele conta que as abordagens tratadas acima raramente eram enquadradas como mobilidade. Abordava-se o movimento como um espaço vazio em que na teoria da migração empurrou as pessoas para fora de um lugar e atraiu outras. Então, apesar de ser sobre movimento, falava-se sobre lugares e não pessoas. Do mesmo modo, os estudos de transporte muitas vezes eram pensados no tempo do trânsito como "tempo morto", no qual nada acontece - um problema que se acreditava ser resolvido tecnicamente. Dessa forma, os estudos de mobilidade recentes começaram a levar a sério o fato do movimento (Ibidem, p. 18). Pensar a mobilidade na relação trabalho, espaço e indivíduo faz-se necessário para compreensão multidimensional do problema.

Barbosa (2016) chama isso de economia dos fluxos, indispensáveis para acumulação do capital. Segundo ele, ruas, avenidas, linhas férreas e rodovias construíram uma morfologia urbana para dar suporte às máquinas circulantes que carregam bens, serviços e trabalhadores, onde energia, matéria e informação estão diretamente envolvidas nesse processo (Ibidem). Tais movimentos carregados de 
significações para essas pessoas, em todas as escalas, são produto e produtores das relações de poder entre movimento e mobilidade como aponta Cresswell (Ibidem). Outro ponto importante é diferenciar a circulação da mobilidade conforme aponta (BARBOSA, 2016); enquanto a primeira se refere ao campo das trocas, da realização de valor, marcadas pela obediência do tempo e definidas por centralidades, a mobilidade permite o afrontamento a essa lógica. Nesse sentido, pensar a mobilidade na cidade vai além das premissas articuladas para circulação da mão de obra somente, como se pensa hoje o mercado, capturando o termo para qualificar os investimentos em transportes a fim da maximização e perfeição do processo de circulação das mercadorias ou da força de trabalho.

Acerca disso, Cresswell (2010) afirma que a mobilidade possuiria três aspectos: o movimento físico; de um lugar para outro; as representações de movimento que lhe conferem significado compartilhado; e, finalmente, a prática experiente e incorporada do movimento. Na prática estariam em uma teia tão interdependentes que não poderiam desembaraçar esses três. Embora dependentes, ao serem utilizado com objeto de pesquisa, é provável que uma das facetas seja mais explorada que outras, como as pesquisas de transportes que focam na frequência do movimento, na velocidade, sobre quem se move e como essa identidade pode fazer diferença. Porém, tais pesquisas muitas vezes não conseguem aprofundar as representações e os significados a nível social ou individual nem falam sobre como a mobilidade é realmente incorporada e praticada, mas ao buscar as subjetividades presentes no problema tem-se a possibilidade de uma pesquisa mais integrada.

Os corpos reais em movimento nunca estiveram no topo da agenda em estudos de transporte. Entender a mobilidade holisticamente significa prestar atenção a todos esses três aspectos. O movimento físico é, se você preferir, a matéria-prima para a produção de mobilidade. As pessoas se movem, as coisas se movem, as idéias se movem. O movimento pode, dado o equipamento certo, ser medido e mapeado. (...) O movimento físico do corpo humano foi extraído de órgãos reais e usados para desenvolver mobilidades modelo para, entre outras coisas, estudos de terapia esportiva, animação e movimento de fábricas (Price, 1989; Yanarella eReid, 1996). Nas cidades, os planejadores de transporte estão criando infinitamente modelos de movimento físico auxiliado, a fim de tornar o transporte mais eficiente ou menos ambientalmente prejudicial (Eliasson e Mattson, 2005). Nos aeroportos e estações ferroviárias modeladores usaram análise de caminho crítico para medir o tempo necessário para dois pontos e depois reduzi-lo (Adey, 2004a). Entendendo o movimento físico é um aspecto da mobilidade. Mas isso não diz quase nada sobre o que essas 
mobilidades são feitas para significar ou como são praticadas. (CRESSWELL, 2010, p.18, tradução da autora).

Para o autor, a mobilidade existe para o movimento assim como o lugar existe para a localização e envolve a tríade: movimento, representação e prática mostra um emaranhado de relações, histórias e geografias amplamente rastreáveis, existindo em uma constelação de mobilidade (Ibidem) que são as formas, os padrões, as representações dos movimentos que fazem sentidos juntos. Além disso, implicaria em políticas de mobilidades particulares imersas em produção e reprodução de poder nas cidades. Sendo assim, as múltiplas mobilidades tenderiam a apresentar ritmos e velocidades diferenciadas.

Portanto, para pensar o desafio do trabalho na esfera do cotidiano temos que concebê-lo como o espaço que se realiza a mobilidade da força de trabalho, na qual o indivíduo realiza um deslocamento constante, muitas vezes com a finalidade de maximizar ganhos. É nesse mesmo espaço de condicionamento que se tem também a possibilidade de superação a lógica alienante e precarizante e que se pode pensar na construção de um humano-genérico consciente. Uma vez que é característica dominante da vida cotidiana a espontaneidade, é por meio dela que o ritmo fixo, a repetição, a rigorosa regularidade da vida cotidiana se rompe.

\subsection{As correntes teóricas da mobilidade}

Como observado anteriormente, as inúmeras formas, ritmos e escalas da mobilidade variam nos diversos tempos e lugares. O estudo da mobilidade espacial encontra-se discriminado na literatura com dois enfoques principais: os neoclássicos e os neomarxistas. Nos estudos clássicos e neoclássicos, em geral anteriores a 1970, a visão era positivista e descritiva; a análise estatística, a ideia de fluxos, volume e distância no espaço físico eram metodologias utilizadas para analisar a mobilidade como fruto de decisão individual de acordo com propensão natural ao movimento, em que a busca por maximização de ganhos, em termos de remuneração do trabalho ou investimentos, é o grande motivador desses deslocamentos. Toma-se o espaço como uniforme e sem relação com os fatores de ordem econômica externa, como aponta Becker (2006). O espaço era analisado como equilibrado ou não de acordo com um padrão pré-determinado de migração. Os nomes clássicos dessas pesquisas, como Ravenstein, Todaro e outros, ficaram conhecidos por enfatizarem os traços 
característicos dos migrantes e pontuarem determinados fatores que condicionaram a migração. Sobre isso, completa Póvoa-Neto (1997, p. 16):

O migrante como portador do fator trabalho, a busca o máximo retorno para seu 'investimento' em um dado ponto de espaço... Tal imagem se assemelha a uma caricatura da primazia do econômico na análise social. Sucede, porém, que a concepção neoclássica é também portadora de um determinado entendimento do papel do indivíduo. Ele é entendido como movido por escolhas racionais que comparam a área de origem do futuro movimento migratório com os potenciais áreas de destino, a partir de características como nível de urbanização, existência de emprego, remuneração média... não importa, no momento, o quão enganosa possa ser está avaliação, que corre o risco de culminar em uma escolha equivocada. Interessa sublinhar que, por trás de um modelo que parece enfatizar a liberdade de escolha individual, o que temos é uma concepção de que a única vontade racional é a vontade do mercado.

Como aponta o autor, a preocupação desses teóricos era a questão da manutenção do equilíbrio econômico no espaço e a função do trabalho. Assim, a mobilidade deveria buscar a perfeição na mesma lógica da circulação de mercadorias na perspectiva de um espaço homogêneo. Todavia, tanto os problemas, quanto as descontinuidades e a imperfeição sistêmica, eram notórias. Assim, a natureza desses estudos tinha como objetivo a eliminação dos obstáculos à mobilidade, tratando a questão como essencialmente política e ideológica, o que acaba por anular a dimensão histórica das migrações, tendo como base a busca natural por melhores condições de vida, visto na época como melhores salários. (Ibidem). Vale ressaltar que esses estudos tomam a dimensão do homem estático para o homem que migra pelo trabalho por sua livre escolha, notando-se a centralidade do trabalho na produção de capital.

Sobre a corrente neomarxista ou histórico-estrutural, destacam-se Singer, Gaudemar, Santos, Harvey, entre outros. Segundo Póvoa-Neto (1997, p. 17), a migração é encarada como fenômeno social, no qual os grupos sociais passam a sofrer pressão das estruturas sociais, proporcionando maior ou menor vulnerabilidade à migração. Becker (2006) afirma que para Gaudemar a mobilidade é essencialmente a mobilidade do trabalho, termo criado por ele para referir-se à concepção da força de trabalho como mercadoria, setorizado de forma espacial e profissional. Tal movimento estaria atrelado ao processo de acumulação capitalista e estaria subordinado ao capital em sua circulação e produção. Portanto, a 
racionalidade do sistema econômico-social articularia os processos migratórios. Nas palavras de Póvoa-Neto (1997, p. 19):

O capitalismo, ao gerar trabalhadores excedentes, separados de seus meios de existência, cria a necessidade dos deslocamentos à busca de trabalho. A disponibilidade de tais trabalhadores, apresentando -se para o assalariamento nos mais diversos pontos do território, torna-se por sua vez condição necessária para a própria existência da acumulação de capital. A migração não é, pois, mero mecanismo de redistribuição espacial de populações, adaptando-se as solicitações do sistema econômico. Ela configura, em suas diversas modalidades, a existência de organizações sócio-espaciais específicas.

Na análise de Gaudemar, os corpos dos trabalhadores, as localizações da produção, os ritmos exprimem a máxima produção de valor, não se referindo meramente aos deslocamentos, mas a chave mestra de toda a estratégia do desenvolvimento capitalista, nas palavras dele (GAUDEMAR, 1979, p.51). Nota-se aqui a ligação com a nossa corporeidade e, a partir dela, o nosso lugar no mundo.

$\mathrm{Na}$ verdade, a globalização faz também redescobrir a corporeidade. O mundo da fluidez, a vertigem da velocidade, a frequência dos deslocamentos e a banalidade do movimento e das alusões a lugares e a coisas distantes, revelam, por contraste, no ser humano, o corpo como uma certeza materialmente sensível diante de um universo difícil de aprender e de tamanha velocidade (SANTOS, 2006, p.212).

Sobre isso, Sennett (2008, p. 15) afirma que a civilização ocidental não tem respeitado a dignidade dos corpos humanos. O ritmo acelerado das grandes cidades e os fluxos de locomoção corroboram cada vez mais para perda de sentidos, em que as pessoas se tornam inconscientes e mais individualistas. Essa falta de contato físico, segundo o autor, expressa a desordem do espaço urbano, pois atualmente ordem é expressa justamente pela impessoalidade. O ato de deslocar-se amplia a desconexão do espaço, pois a velocidade retira a atenção dada à paisagem.

$\mathrm{O}$ viajante, tanto quanto o telespectador, vive uma experiência narcótica; o corpo se move passivamente, anestesiado no espaço, para destinos fragmentados e descontínuos. Tudo isso acontece porque essa transferência só é viável graças a uma outra experiência física - a experiência da velocidade. Hoje em dia, viaja-se com uma rapidez que nossos ancestrais sequer poderiam conceber. A tecnologia da locomoção - dos automóveis às grandes rodovias - permitiu que as pessoas se deslocassem para áreas além da periferia. $O$ espaço tornou-se um lugar de passagem, medido pela felicidade com que dirigimos através dele ou nos afastamos dele (SENNETT,2008, p. 17). 
Segundo Harvey (2012), isso teria a ver com uma dualidade presente na liberdade da força de trabalho; de um lado, mostra-se positiva por se referir à livre possibilidade de percorrer os espaços, de outro lado, mostra-se negativa por não dominar os meios de reprodução. Logo, essa liberdade torna-se moeda de troca, a circulação é livre em busca de compradores da sua força de trabalho e se torna a sua única mercadoria.

[...] como sujeitos criativos, os trabalhadores perambulam eternamente pelo mundo e procuram escapar das depredações do capital evitando os piores aspectos da exploração, sempre lutando com frequência, com algum sucesso, para melhorar seu destino. O capital precisa se ajustar a esse processo, e na medida em que isso ocorre os trabalhadores moldam tanto a história como a geografia do capitalismo (HARVEY, 2012, p. 486).

Desse modo, há uma dupla mobilidade: a do capital que busca extração máxima de mais-valia e a da força de trabalho que se movem pelo mundo buscando valorização de sua mercadoria, derivando os diversos tipos de migração e mobilidade, assim como os meios e técnicas que surgem para ampliar esse processo. Visão essa diferente da corrente anterior em que colocava a liberdade do trabalhador no centro das questões migratórias, partindo da escala do indivíduo em um sistema em perfeição, sem considerar as crises e os ajustes espaciais. $\mathrm{O}$ foco que havia nas matérias-primas e nos bens de capital, como se fazia nas fases anteriores do capitalismo, agora torna-se fluxos graças ao desenvolvimento da informação e dos transportes. A mobilidade, a migração do capital e do trabalho refletem novas espacialidades na economia mundial, escolhendo perfis e tornando-se subjetivas aos indivíduos que trabalham.

Designa-se, com o conceito de mobilidade do trabalho, um processo abrangente, no qual os homens tornam-se crescentemente disponíveis para a utilização compulsória de sua força de trabalho nos moldes capitalistas. O deslocamento no espaço seria, segundo tal perspectiva, apenas uma dimensão daquele processo. O mesmo implicaria, em primeiro lugar, população, na produção da força de trabalho, momento da aquisição de sua mobilidade por parte do trabalhador, designado por Marx como sendo o da acumulação primitiva; em seguida, na utilização da força de trabalho, onde se aprofunda a divisão do trabalho; finalmente, na circulação da força de trabalho, momento da submissão do trabalhador às forças de mercado, deslocando-se (espacial e/ou setorialmente) entre os diversos ramos da atividade econômica (GAUDEMAR,1979, 193-195) 
A ideia de mobilidade do trabalho, segundo Gaudemar (1979), não só se refere a mudança espacial, mas também de funções, de empregos, que podem se traduzir nas mudanças espaciais, decorrentes das crises estruturais, conjunturais e da precarização do trabalho. $\mathrm{E}$ isso relaciona-se às condições de desenvolvimento local, referindo-se à localização das áreas produtivas, de acordo com os determinantes geográficos como clima, aspectos políticos, aspectos naturais, entre outros e que acabam por determinar os movimentos espaciais para além da vontade dos indivíduos. Desse modo, ao pensarmos nas migrações internas é necessário pontuar o Estado como grande articulador desses fluxos, uma vez que os investimentos, o planejamento seguirá as intencionalidades deste agente, que, muitas vezes, encontra-se submetido a pressões econômicas externas.

Para Becker (2006), Gaudemar com sua terminologia "mobilidade forçada" referese ao processo histórico de obrigar o trabalhador a aceitação das condições de trabalho existentes, onde a migração passa a ser vista como uma sujeição do trabalho ao capital. Desse modo, ele caracteriza a mobilidade em um sentido duplo: espacialmente, também vista como horizontal, e a mobilidade social, também chamada de vertical. A primeira é a expansão do trabalho para formar o mercado de trabalho, e a segunda é a fluidez entre os setores e funções da produção. Santos (1992) chama isso de horizontalidade, referindo-se a espaços diferentes, e verticalidade, abordando as classes sociais. Ambas possuem grande relação com a expansão urbana vistas nas últimas décadas a fim de ampliar o consumo e absorver a mão de obra em massa. Assim, a história urbana também é a história das migrações, uma vez que os espaços de aglomeração se misturam aos espaços produtivos e a partir disso derivam-se novas formas de mobilidade, como a pendularidade.

\subsection{Mobilidade, geografia e a teoria socioespacial}

Um dos pioneiros dos estudos de migração foi Friedrich Ratzel em suas abordagens políticas a antropogeográficas levantou questionamentos acerca da migração. Levava em conta, em sua obra, as categorias, as classificações e a intensidade dos movimentos nômades e dos caçadores. Mesmo sendo apontado como determinista, existe um grande consenso acerca de sua contribuição para a migração como temática da Geografia. Sua preocupação com os seres vivos, inclusive o homem, 
sob a luz do pensamento darwinista, o colocou em caráter de relação entre a migração e o clima, por exemplo, uma vez que, para a realidade das sociedades primitivas, isso era elemento crucial na fixação e na movimentação dos povos.

Embora hoje se utilize a dimensão econômica para explicar as migrações humanas, frutos da produção capitalista, foi de extrema riqueza para a ciência geográfica a abordagem ratzeliana agregando outros sentidos, conforme momento histórico. A etnografia era um elemento central em suas obras, uma vez que se concentrava nas diferenças, na origem, na direção dos povos. Nota-se que a ideia de movimento abordada anteriormente também se fazia presente nessa corrente tradicional.

Nessa corrente teórica, o espaço não era o conceito central para qual se pensasse esses movimentos, a localização dos indivíduos e seus fluxos ficavam em segundo plano. Ratzel desenvolveu, portanto, um pensamento sobre o território e no que ele denomina de espaço vital. O primeiro; uma área apropriada por um dado grupo primitivo, e o segundo; referente aos meios de subsistência dessas sociedades conforme seu desenvolvimento técnico, conforme a disponibilidade de recursos naturais e de acordo com o tamanho de sua população. Nesse sentido, sua contribuição para pensarmos o território atual.

Já na fase da Nova Geografia ou Geografia teorético-quantitativa, surgida com a ascensão dos Estados-Nacionais e preocupada com a quantificação dos fenômenos, na elaboração de modelos matemáticos e estatísticos para explicar a realidade, o espaço não só se refere à combinação dos elementos naturais com a ocupação humana, mas também se refere à economia, criando análises locais e então, por exemplo, a ideia de redes, hierarquias e movimentos, passa a ser sistematizado. Demógrafos, economistas e geógrafos passam a se interessar pelo estudo das migrações.

Já na corrente mais recente da geografia conhecida como Geografia crítica, o espaço toma papel de destaque, pautado nos estudos de Marx para explicar a dominação da natureza e a construção do espaço. O espaço é sempre aberto e passível de imprevisibilidades, também chamado de espaço do vivido. Tenta-se superar a ideia de Geografia idiográfica de Hartshorne da descrição das coisas e nomotética de antecipar resultados e criar padrões. Como aponta Corrêa (2000), essa perspectiva preocupa-se com a reprodução das relações sociais de produção, ou seja, a reprodução da sociedade. 
Para essa corrente, o espaço não é um fenômeno, existe uma produção social deste. Milton Santos se destaca nesses estudos afirmando este conceito é central para a geografia, e o define como um como um "conjunto indissociável de sistemas de objetos e ações" (SANTOS, 1992, p.52) e que atual mundialização, onde a existência de um modelo técnico uniformizante se sobrepõe à multiplicidade dos recursos naturais e humanos (Ibidem, p.150). Para ele, a expansão tecnológica que vemos atualmente integra cada vez mais espaços e pessoas e tais fluxos são percebidos, concebidos e vividos na dimensão espacial do lugar, ou seja, aquele que remete significação próxima aos sujeitos sociais.

Segundo Souza (2013, p.32), a organização espacial e a produção do espaço são conceitos derivados do espaço social onde a primeira refere-se ao conjunto de objetos criados pelo homem e sua disposição na superfície terrestre (CORRÊA, 1986, p.57 apud SOUZA, 2013, p.37), ou seja, relaciona-se com a ideia de ordem e desordem, na qual é submetida a um padrão cultural enraizado que aparece carregada de forte carga ideológica; a boa ordem é aquela em vigor e hegemônica, e a desordem aquela que foge do padrão pré-estabelecido. E a segunda, como aponta Lefebvre, (1983, apud SOUZA, 2013, p.39) é de suma importância para acumulação capitalista, não só na produção de bens móveis e imóveis, como também no envolvimento da produção simbólica e de relações de poder. Nesse caso, há uma hierarquia no espaço que reproduz nas diversas escalas o modelo social hegemônico e heterônomo que emerge a novas significações, novas formas e novas práticas.

No que se refere à produção do espaço, trata-se de uma relação dialética entre produto e produtor que estabelece as relações econômicas e sociais vivenciadas na esfera do lugar (LEFEBVRE, 2008). Assim, o espaço possuiria múltiplas dimensões, nas quais as técnicas se sobrepõem aos recortes escalares. As técnicas, segundo Santos (2006), correspondem a um conjunto de meios instrumentais e sociais nos quais o homem realiza a sua vida, produz e ao mesmo tempo cria espaços. A influência da técnica sobre o espaço se exerce de duas formas principais: a ocupação do solo pelas infraestruturas das técnicas modernas e as transformações impostas pelo uso da máquina e execução dos novos métodos de produção.

A realidade estaria relacionada diretamente na produção desigual das técnicas e na seletividade do espaço. As técnicas referem-se a maneira pela qual as pessoas se apropriam das coisas. Ela é mediada pelo sistema de objetos, na qual a natureza é 
transformada pelo homem, e pelo sistema de ações, para qual finalidade deseja-se alcançar. As populações se adaptam a um território e criam técnicas para adaptá-lo às suas necessidades. Logo, as técnicas definem a sociedade, pois os objetos são criados para se apropriar de determinado território e estes podem ser tanto naturais quanto sociais; quanto mais próximo do natural é o objeto mais imperfeito, quanto mais técnico mais perto da perfeição, pois permite um comando mais eficaz do homem sobre ele. Assim, o objeto técnico concreto acaba sendo melhor acabado que a própria natureza. Ela própria é um meio, uma seleção Darwiniana na qual pode se obter êxito ou fracasso e que se configura como uma necessidade de sobrevivência.

O espaço interfere no fenômeno técnico e este na produção e nas transformações do espaço geográfico. As técnicas são uma medida do tempo, tempo de circulação, tempo da divisão territorial, tempo do trabalho, da cooperação. Além disso, Ciavatta (2014, p. 199) afirma que é de fundamental importância considerar tempo e espaço como categorias centrais para evitar esta compreensão equivocada do real. Sobre isto, ela completa que a mediação entra como categoria central na concepção dialética, pois é a especificidade histórica do fenômeno, assim "situa-se no campo dos objetos problematizados nas suas múltiplas relações no tempo e no espaço, sob ação dos sujeitos sociais" (Ibidem, p.209).

Assim, compreender o espaço a partir da historicidade dos fatos implica na negação da ideologia dominante, uma vez que abordam como natural o que é histórico, fundamentam isso para uma aceitação coletiva, e onde o permanente torna-se passageiro, reificando o real e separando o movimento e a contradição. Diz ela: "A história é o mundo das mediações. E a história, enquanto movimento do próprio real, implica o movimento das mediações. Assim, elas são históricas e, nesse sentido, superáveis e relativas" (CURY, 1985, p.43 apud CIAVATTA, 2014, p.211). Completa Massey (2008, p. 94):

Conceber o espaço como um recorte estático através do tempo, como representação, como um sistema fechado, e assim por diante, são todos modos de subjugá-los. Eles nos permitem ignorar sua verdadeira relevância: as multiplicidades coetâneas de outras trajetórias e a necessária mentalidade aberta de uma subjetividade espacializada. Se o tempo deve ser aberto para um futuro do novo, então o espaço não pode ser equiparado com os fechamentos e horizontalidades da representação. De um modo mais geral, se o tempo deve ser aberto, então o espaço tem de ser 
aberto também. Conceituar o espaço como aberto, múltiplo e relacional, não acabado e sempre em devir, é um pré-requisito para que a história seja aberta e, assim, um pré-requisito, também, para a possibilidade da política (Massey, 2008, p. 94).

McMaster e Shepard (2004, p. 16, tradução nossa) nos impõem uma pergunta essencial: "se o espaço não é uma dimensão exógena e fixa, mas é moldada por processos sociais, como podemos explicar a construção do espaço e da escala em nossas explicações da sociedade?"

Para responder ele recorre ao conceito de "glocalização": forças econômicas que impulsionam a globalização e que se referem a essa escala macro, mas também a regiões metropolitanas subnacionais que se tornam escalas geográficas mais importantes nas mudanças econômicas do que a escala nacional. A escala, portanto, é um elemento de grande valia para esta discussão.

A globalização, como momento histórico atual, detém a vontade de associação entre as organizações e a tecnologia cegamente utilizada, ela introduz novas técnicas em lugares distintos objetivando a homogeneização. Mas a realidade dos territórios impede essa homogeneização. Assim, a tendência de homogeneização é confrontada pelo local onde a técnica foi implementada e sua historicidade. Há uma relação implícita de poder em que a homogeneização nunca se completa, porque contraditoriamente há uma permanente desigualização.

Para o autor, se o espaço intervém no modo de produção, ao mesmo tempo como efeito causa e razão, ele muda com esse modo de produção, muda com as sociedades, por isso a historicidade do espaço. O modo de produção organiza, produz ao mesmo tempo que as relações sociais o seu espaço. Não se pode dizer que o modo de produção capitalista tenha desde o início ordenado a sua extensão espacial na qual ao nosso tempo se estende ao planeta inteiro.

Segundo o autor, houve, primeiramente, utilização do espaço existente, como, por exemplo, as vias hídricas, depois as estradas, depois ferrovias e autoestradas, entre outros. Não houve um desaparecimento nem da caminhada a pé, nem a cavalo, nem das viagens de trem; assim o espaço é uma sobreposição de tempos que ocorre de forma inacabada e contínua. A homogeneidade mata o tempo e por tabela mata o espaço - porque o espaço é o acúmulo de tempos que o tornam heterogêneo - onde as diferenças não são privilegiadas. Assim, alguns espaços teriam mais acúmulo de tempos do que outros. Nesse sentido, o espaço consistiria em um sistema de objetos, 
ações, integrados pelas técnicas e intencionalidades ligados pela hibridez dos lugares.

As duas categorias, objeto e ação, materialidade e evento, devem ser tratadas unitariamente. Os eventos, as ações não se geografizam indiferentemente. Há, em cada momento, uma relação entre valor de uso e o da ação do valor do lugar onde ela se realiza; sem isso, todos os lugares teriam o mesmo valor de uso e o mesmo valor de troca, valores que não seriam afetados pelo movimento da história. Há uma diferença entre dizer que o espaço não é uma causa e negar que ele é um fator, um dado. Admitir a "existência" do espaço não é ser "geodeterminista", como na crítica de Werlen (p.6). Pois o valor do espaço não é independente das ações que ele é susceptível de acolher. O espaço geográfico deve ser considerado como algo que participa igualmente da condição social e do físico, um misto, um híbrido. Nesse sentido não há significações independentes dos objetos. (SANTOS, 2006, p.56)

Outra abordagem de espaço trata-se da divisão tripartite: espaço absoluto, espaço relativo, espaço relacional, defendida por Harvey (1992, p.10). O espaço absoluto é fixo, constituído pelo espaço da individualização, onde são registrados ou planejados eventos. É o espaço do mapeamento, da localização das fronteiras, dos condomínios, das cidades e das barreiras físicas que delimitam as unidades administrativas. O espaço relativo está associado às múltiplas geometrias e ao que está sendo relativizado e por quem. Esse espaço aborda não só as localizações, mas a relações com custo, tempo, modalidade de transporte entre outras. É o espaço da circulação e dos fluxos, da mobilidade e compressão do espaço-tempo.

Essa ideia converge com a concepção de espaço de Santos (2006) como um conjunto de fixos e fluxos que redefinem cada lugar, onde os fixos estão cada vez mais artificiais e mais fixados no solo e os fluxos por ter ação essencial de modificação dos fixos estão cada vez mais diversos, numerosos e rápidos. Além disso, há o espaço relacional que implica na ideia de relações internas, onde um evento não pode ser compreendido como isolado, mas sim independente de tudo que ocorre no entorno, é o espaço das sensações, dos sonhos, dos desejos.

Nas palavras de Lefebvre (apud Harvey, 1992), o espaço seria material (aquele constituído da experiência e da percepção física), seria na forma de representação do espaço (aquele que é concebido e representado) e também seria o espaço da representação (aquele que é vivido, sentido e possui significados). No espaço concebido e absoluto é que se tem o valor de uso do trabalho concreto, ou seja, a propriedade privada, as exclusões de classe, e os desenvolvimentos geográficos 
desiguais. E no espaço concebido e relativo a representação se dá pelo valor de troca, ou seja, circulação do capital, pessoas, formação do mercado mundial, redes, relações geopolíticas.

O espaço não é nem absoluto nem relativo, nem relacional em si mesmo, mas ele pode tornar-se um ou outro separadamente ou simultaneamente em função das circunstâncias. O problema da concepção correta do espaço é resolvido pela prática humana em relação a ele. Em outros termos, não há respostas filosóficas a questões filosóficas que concentrem natureza do espaço que concernem natureza do espaço - às respostas se situam na prática humana. A questão "o que é espaço?". A relação de propriedade, por exemplo, cria espaços absolutos nos quais o controle monopolista pode operar. O movimento de pessoas, de bens, serviços, informação realiza-se no espaço relativo porque o dinheiro, tempo, energia etc., são necessários para superar a fricção da distância. Parcelas de terra incorporam benefícios porque contém relações com outras parcelas, sob a forma do arrendamento o espaço relacional se torna um aspecto importante da prática social humana (Harvey, 1973, apud Harvey, 2012, p.14 e 15).

Tanto esta análise quanto outra divisão tripartite defendida pelo autor como a experiência espacial orgânica, perceptiva e simbólica correspondem às múltiplas relações contidas no espaço. $\mathrm{Na}$ experiência orgânica, as formas biológicas e materiais são privilegiadas, enquanto o espaço perceptivo se refere às maneiras pelas quais processamos a experiência física e biológica e registramos em nosso pensamento. E o espaço simbólico designa o que é abstrato e submetido às leituras e interpretações de mundo. Assim, a sensação de uma mobilidade positiva ou negativa, por exemplo, teria variações de pessoa para pessoa.

Ainda segundo o autor, as três categorias coexistem em uma tensão dialética na qual a experiência física e material da ordem espacial e temporal é mediada pela maneira como o espaço e tempo são representados. Os espaços e os tempos da representação que nos envolvem e nos rodeiam na vida cotidiana afetam tanto as experiências diretas quanto nossa interpretação e compreensão de mundo (ibid., p.20). Assim os espaços construídos possuem dimensões materiais concebidas e vividas. Desse modo, é na esfera do espaço relativo que se tem os deslocamentos e a mobilidade urbana. E é na esfera do espaço de representação que se tem os sentimentos derivados dessa mobilidade, como aponta o autor, a ansiedade por não chegar no horário, a frustrações no engarrafamento, as tensões ou divertimentos resultantes da compressão do espaço-tempo da velocidade e do movimento. 
A mobilidade intraurbana ou pendular nessa dinâmica do espaço urbano ocorreria mais intensamente em áreas de maior concentração da população, direcionando sua organização e alocação das atividades econômicas mediante os interesses dos agentes de transformação do espaço urbano, tendo a mobilidade derivada em grande parte pela expansão, ocupação da população e distribuição das funções urbanas. Aqui vale resgatar a relação entre território e população que é dada pela apropriação do espaço, pelo seu uso, tornando o local o ponto pela realização concreta de ações cotidianas que o modificam, como trabalho, moradia, estudos, lazer.

Compreender a mobilidade populacional dentro do processo de produção do espaço é levar em consideração as questões de assentamento urbano desigual, concentração e descentralização espacial, sítio urbano, planejamento urbano, gestão pública, entre outras problemáticas abordadas na análise geográfica.

Nesse sentido, é de fundamental importância, levar em consideração as intencionalidades dos agentes que determinam nas esferas globais as ações que serão efetivadas em práticas sociais em escala local. Conforme Rua (2007, p.161), o espaço assim como o território necessita ser percebido como político e pleno de relação de poder, que é exercido através de discursos de dominação e resistência. Assim, as representações do espaço convergem para projeção das potências hegemônicas sob as culturas dominadas e ao mesmo tempo se criam oposições a estas representações hegemônicas na forma de resistência e conflitos que promovem o processo de reterritorializações. Ideia essa disseminada pela concepção de território e territorialidade defendida por Haesbaert (2014 apud RUA, 2007, p.161), ao qual relaciona o espaço ao poder político que exerce estratégia de dominação através da apropriação. Logo, a territorialidade torna-se uma forma para se experimentar o mundo e torná-lo significativo, visando à manutenção do espaço geográfico (Ibidem). É no vivido que as práticas espaciais cotidianas impõem a agressividade multiescalar das transformações criadoras de representações.

Como afirma Rua (2007), se o território é marcado por relações de poder, explícitas ou simbólicas, exercidas por atores diversos, numa arena de confronto de visões de mundo. Territorializar-se (transformar o espaço em território) por apropriação (valor de uso) ou por dominação (valor de troca) significa participar de conflitos que expressam a mudança e, portanto, o desenvolvimento.

É importante frisar que essas relações de poder não se dão somente pelo Estado ou pela influência econômica na vida local. Para Elden (2017), o território é um 
processo, não um resultado, possui relações entrelaçadas de produção, transformação e contestação. Sob a atuação de alguns grupos políticos, podem-se gerar migrações em massa como assistimos atualmente a árabes e magrebinos refugiados. No entanto, na escala local isso também acontece com os territórios marcados pela violência, que não necessariamente expulsam as pessoas, mas dominam suas liberdades, inclusive a de ir e vir.

Acerca da "desterritorialização", Haesbaert(2007) aponta que esta poderia dissolver e enfraquecer o controle de fronteiras, aumentando assim a mobilidade de pessoas, mercadorias e capital.

(...) um dos fenômenos mais freqüentemente ligados à desterritorialização diz respeito à crescente mobilidade das pessoas, seja como novos nômades, vagabundos, viajantes, turistas, imigrantes, refugiados ou como exilados - expressões cujo significado costuma ir muito além de seu sentido literal, ampliando-se como poderosas (ou ambivalentes, assim, controvertidas) metáforas. Toda uma cultura das viagens e mesmo uma travelling theory passou a se desenhar a partir da crescente mobilidade pós-moderna. Entretanto, até que ponto a mobilidade geográfica pode ser vinculada à desterritorialização (HAESBAERT, 2007, 237).

Para o autor, os territórios não estariam desaparecendo, mas sim novos territórios são criados a partir destes movimentos. Levando em conta alguns movimentos de migração, para estas pessoas a perda do território é inegável, fazendo com que se sinta sem lugar no mundo, mas, ao mesmo tempo, ocorre a busca pela integração ao novo território. Para além disso, a categoria território nos ajuda a pensar as transformações na localização que os circuitos produtivos podem causar.

Sobre isso, o autor retorna Lefebvre (1974, p.32 apud RUA, 2007, p.162) para explicar que o espaço apresenta simbolismos aparentes e ocultos características do cotidiano do singular, e do vivido, em que transmite as mensagens de dominação, concebidas e aceitas como a única alternativa. Tais estratégias de dominação se materializam em relações e modos de produção que envolvem representações ideológicas e científicas.

A representação não é apenas aparência e acaba se tornado concreta, pois ganha o poder de bloquear, de fazer acreditar no que não é. A realidade se dissimula, logo se translúcida e se modifica, representando-se como uma mediação, um determinado olhar. $\mathrm{O}$ estudo das representações permite compreender o processo pelo qual a força do representado é suplantada pelo seu representante por meio das 
representações, e como estas representações se distanciam do vivido e se multiplicam manipulando o vivido (Lutfi et al. , 1996, p.89). Quando falarmos em espaço de representação e representação dos espaços, bem como em práticas espaciais, estaremos nos reportando a essa construção de Lefebvre, da relação espaço sociedade e as suas implicações com poder e hegemonia, no exercício da dominação e resistência.

Nesse sentido, para compreendermos as contradições expressas no vivido é necessário recorrer à compreensão de desenvolvimento geográfico desigual apresentado por Lefebvre (apud RUA, 2008, p. 8), em que há uma relação entre espacialidade e Estado, periodização do capital e seus efeitos no espaço, havendo uma dupla tendência do capital tanto para homogeneizar quanto para diferenciar os lugares, sob o argumento desenvolvimentista.

O espaço é, portanto, uno e diferenciado, formado por um conjunto de homens cujos valores pessoas são desiguais, no qual o uso é disputado a cada instante, gerando o fenômeno de escassez. Como afirma Santos (2006, p. 216), as cidades e sobretudo as metrópoles, abertas ao mundo, não são menos individualizadas. Tais lugares possuem uma rede densa de fluxos, onde muitas vezes os deslocamentos internos superam as viagens para outros espaços. "A cidade é o lugar onde há maior mobilidade, mais encontros". Esse movimento é potencializado nos países subdesenvolvidos, onde a situação de baixa renda atrelada ao tamanho desmedido das metrópoles e ao menor planejamento da máquina urbana geram um sistema de subproletarização do movimento urbano.

Ainda segundo o autor, diante da modernização contemporânea, multidões são expulsas do campo para as cidades médias com o objetivo de se ter acesso a serviços, aumentando assim a quantidade de pobres na cidade e de diversidade socioespacial. Isso ocasiona ampliação das divisões do trabalho, como também da interação de necessidades. Pois a variedade de ofícios culmina na proximidade e na comunicação entre as pessoas, uma vez que na cidade pessoas desconhecidas trabalham conjuntamente para alcançar resultados coletivos. Santos (2006, p.222) afirma que a mobilidade atualmente se tornou praticamente uma regra. "O movimento se sobrepõe ao repouso. A circulação é mais criadora que a produção". Os homens se deslocam de lugar tanto como turistas quanto imigrantes, assim como os produtos, as mercadorias, as imagens e as ideias, gerando tanto a 
desterritorialização quanto a desculturização. Tal fato se deve a um descompasso entre ordem local e a ordem global.

A rede técnica mundializada atual é o instrumento da produção, da circulação e da informação mundializadas. Nesse sentido, as redes são globais e, desse modo transportam universal ao local. É assim que, mediante telecomunicação, cria-se espaços globais unindo pontos distantes numa mesma loja produtiva. É o funcionamento vertical do espaço geográfico contemporâneo. Mas as redes também são locais e, nessa condição, constituem as condições técnicas do trabalho direto, ao mesmo modo que as redes globais asseguram a divisão do trabalho e a cooperação, mediante as instâncias não-técnicas do trabalho - a circulação a distribuição e o consumo. (SANTOS, 2006, p.227).

A luta pelos usos do espaço coloca atores globais e locais em uma situação conflitante. "Quanto mais desigual a sociedade e a economia, tanto maior é o conflito" (ibid., p.228). Dessa forma, a velocidade em si mesma é um conflito, pois o interesse das grandes empresas é economizar tempo, aumentando a velocidade de circulação, enquanto o interesse da comunidade local é frequentemente o oposto. “A ordem global busca impor a todos os lugares uma única racionalidade. E os lugares respondem ao mundo segundo os diversos modos de sua própria racionalidade". (ibid., 230).

Assim, diante da imposição da ordem hegemônica, o fenômeno da mobilidade se constitui tanto como produto quanto produtor do e no espaço urbano, como causa e efeito, uma vez que se trata de uma intencionalidade do processo de construção das redes urbanas, como resultado do processo de ampliação das técnicas. Milton Santos (2006, p.220) coloca em questionamento a relação tempo-mobilidade diante de um processo de flexibilização que exige agilidade, mobilidade no cotidiano laboral das pessoas.

"Durante séculos, acreditáramos que os homens mais velozes detinham a inteligência do Mundo. [...] Agora, estamos descobrindo que, nas cidades, o tempo que comanda, ou vai comandar, é o tempo dos homens lentos. Na grande cidade, hoje, o que se dá é tudo ao contrário. A força é dos "lentos" e não dos que detém a velocidade elogiada por um Virilio [...]. Quem, na cidade, tem mobilidade - e pode percorrê-la e esquadrinhá-la acaba por ver pouco, da cidade e do mundo.”(SANTOS, M., 2006, p.220).

Nesse sentido, o discurso hegemônico imposto cada vez mais corrobora para uma ideia de mobilidade para a circulação de mercado. Porém, o andar pela cidade, as 
distâncias percorridas, os transportes ofertados em determinados lugares são diferenciados conforme acesso das classes sociais. Os atores que planejam e controlam o processo de deslocamento urbano em geral não levam em conta os indivíduos pobres e suas necessidades, mas sim as necessidades dos atores hegemônicos, dos grandes grupos empresariais rodoviários, dos consórcios do ramo do transporte, entre outros.

Vale ressaltar aqui o papel do público e privado no espaço. Harvey (2012) coloca em questão o espaço como grande mercadoria; nesse sentido, ele não se configura abstrato, mas sim absoluto, relativo e relacional, produzido, apropriado de forma desigual, submetido a relações de poder nas quais torna-se palco de disputa de diferentes atores. É necessário, ao falar de espaço público, que o conceba como também proprietário dos meios de produção e do espaço absoluto (delimitação administrativa), porém de modo aberto, mas não comum (ou seja, oposto à propriedade privada), ele pode ser apropriado e seus objetos utilizados por todos, mas há regras.

A ideia de bem comum e bem-estar social torna-se submetida aos interesses dos grandes grupos empresariais. Inúmeros são os exemplos disso ao se pensar sobre as empresas de ônibus que operam nas grandes cidades, com valores abusivos da passagem, em condições precárias e superlotações, sem contar aspectos caóticos do funcionamento das grandes metrópoles como congestionamentos que, na esfera do espaço vivido, tornam as relações humanas cada vez mais degradadas e submetidas à lógica de sobrevivência e disputa no espaço, como o duelo em horário de rush para se conseguir um assento no trem ou metrô, ou mesmo entrar neles.

Porém, a crítica a tais condições que perpassam o cotidiano não devem ser restritas e esgotada aos objetos ou aos comportamentos dos indivíduos, pois fazer isso corresponde a uma análise rasa da problemática. Ao pensar a mobilidade populacional faz-se necessário compreender os processos que a determinam a partir das ações que contribuem para diferenciação de classes e como podem percorrer o espaço. Pensar nos meios que transportam tais indivíduos, no tempo gasto, nas distâncias percorridas significa levar em conta a noção de bem-estar que fora banalizada e substituída pelo discurso do consumo na sociedade atual. A condição para a cidadania na ordem hegemônica não se dá pela visibilidade das necessidades dos indivíduos, mas sim pela imposição à contribuição laboral deste como força de trabalho. 
Pensar a mobilidade nas grandes cidades é ater-se às intencionalidades que comandam e envolvem o trabalho humano. Em tempos de flexibilização, a ampliação das necessidades de locomoção coloca o trabalhador em uma situação de naturalização das situações degradantes, nas quais favorecem o processo de alienação, vivenciado em um cotidiano opressor, no qual as necessidades humanas o obrigam a sucumbir aos deslocamentos por vezes desgastantes no espaço urbano. Refletir tal processo não equivale se opor à mobilidade evidenciando o lugar de residência do indivíduo como sacralizado, fechado ou etnocêntrico.

A difusão das culturas, a ampliação das técnicas, das redes de solidariedade humanas, a socialidade humana por meio da revolução técnica propiciaram ao homem maior conhecimento de mundo, mas ao mesmo tempo limitaram outros a percorrer e conhecer este mundo e para outros tensionaram ao máximo o movimento que não se pôde observar o mundo. Dessa maneira, o discurso sedutor da mobilidade, como acessível a todos e que contempla a garantia da cidadania, esbarra em seus lados opostos: a imobilidade e a hipermobilidade de pessoas.

\subsection{Metropolização e mobilidade}

Como exposto anteriormente, é na cidade que a tirania do movimento se faz presente. Para além da cidade, o que se tem hoje é um processo de metropolização dos espaços. Como aponta Ferreira, Rua \& Mattos (2015, p.15) esse fenômeno está intimamente ligado à desindustrialização, à desconcentração e à explosão das metrópoles, que ultrapassam os limites das regiões metropolitanas delimitadas, incorporam as cidades médias e o chamado "mundo rural" (grifo dos autores). A mobilidade possui papel central nessa expansão. Como aponta os autores, a metropolização incorpora como principal característica o intenso fluxo de pessoas, mercadorias e capitais.

Os adensamentos urbanos, o espraiamento da metrópole e as operações urbanas de construção e reconstrução, associados a grandes investimentos de capital financeiro geram nas cidades enormes espaços de desigualdade. A homogeneização das formas também é característica desses espaços e o ímpeto empreendedor toma conta das políticas de planejamento urbano e especulação. As chamadas parceriaspúblico-privadas dominam as diversas dimensões dos serviços públicos com a intenção de fomentar a competitividade e a produtividade para se inserirem no 
mundo globalizado (Ibidem, p.18). Tal processo é caracterizado por obedecer à lógica de acumulação capitalista, a mesma adotada pelo modelo fordista.

Lencioni (2013 apud BARBOSA, 2016, p. 44) conceitua a metropolização como processo que amplia a homogeneização do espaço, a sua fragmentação e modifica a hierarquização dos lugares, através do desenvolvimento de infraestruturas, como as redes de circulação, a provisão de serviços públicos e as redes informacionais e comunicacionais.

Assim, a hierarquização dos espaços e dispersão dos circuitos produtivos para as áreas interioranas geram a desconcentração metropolitana. Como vimos, para Santos (1992) e para Soja (1993), a mola propulsora para esse processo que causa a diferenciação espacial é a divisão do trabalho. Portanto, suas crises são inevitáveis e elas aparecem no cotidiano das pessoas que ali habitam.

Com aponta SOJA (1993), a metrópole apresenta diferentes feições conforme localidade. Segundo ele, em países de economia avançada, os núcleos urbanos terciários tornam-se crescentes sedes para as empresas. Esses núcleos são rodeados por eixos urbanos residenciais da classe trabalhadora e extravasam as unidades político-administrativas. Esse processo se caracterizou pela crescente fragmentação das unidades que já existiam. Podemos pensar com isso a expansão da rede urbana fluminense, seus processos de emancipação e fragmentação municipal.

Bilsborrow (1998 apud Oliveira, 2009) aponta os conceitos de circularidade e pendularidade como formas de deslocamento que se relacionam a estes processos urbanos. Ele aponta a circularidade "como o movimento no qual a pessoa, sem ter mudado de residência, em um período de 30 dias, passe fora de casa a trabalho ou outras atividades." (Ibidem, p. 17). Já o conceito de pendularidade refere-se aos movimentos diários para trabalho e estudo. Ele aponta que a melhor maneira de se captar esses tipos de migração seria por meio de pesquisas amostrais específicas, dadas as restrições inerentes aos levantamentos censitários. Para ele os movimentos circulares ocorrem a partir de uma residência fixa e necessitam de permanência em um outro lugar por um mínimo de intervalo citado. Já Oliveira (2009) aponta que esta definição de pendularidade é muito restrita a movimentos diários, ele também inclui nesta categoria os deslocamentos para acesso aos serviços de lazer, saúde e comércio, entre outros.

Com isso, os deslocamentos pendulares para o trabalho assumem grande importância, integrando núcleos urbanos atrás da relação das áreas centrais com as 
áreas residenciais. A mesma lógica acontece na escala global, com a centralidade de algumas cidades e países em relação a outras, favorecendo fluxos internacionais. Segundo Barbosa (2016), o processo de metropolização acompanha e realiza o movimento constitutivo da metrópole como momento diferenciado do processo de acumulação e em função de suas exigências, o que explicita o desenvolvimento do tecido urbano que, a partir do centro, desenvolve-se até a periferia com conteúdo diferenciados em seu processo de extensão. Assim, os investimentos percorrem os fluxos que lhes oferecem vantagens, anulando pessoas nesse planejamento.

Desse modo, temos um maior número de investimentos na cidade do Rio adquirindo papel central na dinâmica metropolitana, porém também apresenta diversos problemas no que tange o deslocamento. Segundo uma pesquisa feita pela agência inglesa Expert Market (2019) com 74 cidades de 16 países, levando em conta principalmente o custo e o tempo gasto no deslocamento, a cidade do Rio de Janeiro ocupa o último lugar. A explicação para este resultado deve-se principalmente ao

\begin{tabular}{|c|c|c|c|c|c|c|c|}
\hline $\begin{array}{l}\text { (ônibus } \\
\text { distânc } \\
\text { jornada } \\
\text { como n }\end{array}$ & $\begin{array}{l}\text { ou trem) ch } \\
\text { a percorrida } \\
\text { mais longa } \\
\text { ostra a class }\end{array}$ & $\begin{array}{l}\text { ga a } 19 \mathrm{~m} \\
\text { té o trabal } \\
\text { ealizada p } \\
\text { ficação ab }\end{array}$ & $\begin{array}{l}\text { utos por di } \\
\text { o é de } 12,3 \\
\text { trabalhado } \\
\text { xo. }\end{array}$ & $\begin{array}{l}\text { seja de ônil } \\
\text { res Segundo } \\
\text { res comp }\end{array}$ & $\begin{array}{l}\text { us ou trem } \\
\text { o estudo, ess } \\
\text { aração as ou }\end{array}$ & $\begin{array}{l}\text { a média d } \\
\text { é a terceir } \\
\text { ras cidades }\end{array}$ & \\
\hline \multicolumn{4}{|c|}{ As melhores cidades para deslocamento } & \multicolumn{4}{|c|}{ As piores cidades para deslocamento } \\
\hline Classificação & País & Cidade & Pontuação & Classificação & País & Cidade & Pontuação \\
\hline 1 & França & Nice & 11.05 & 65 & Reino Unido & Londres & 68.18 \\
\hline 2 & Equador & Cuenca & 14.78 & 66 & EUA & Miami & 72.87 \\
\hline 3 & Espanha & Bilbao & 15.08 & 67 & Colômbia & Cali & 75.96 \\
\hline 4 & França & Toulouse & 16.02 & 68 & Brasil & Brasília & 77.52 \\
\hline 5 & Itália & Catania & 17.82 & 69 & Canadá & Toronto & 78.56 \\
\hline 6 & Itália & Bari & 18.83 & 70 & Brasil & Salvador & 78.71 \\
\hline 7 & França & Lyon & 18.94 & 71 & Turquia & Istambul & 81.78 \\
\hline 8 & Itália & Bologna & 20.27 & 72 & Brasil & São Paulo & 83.71 \\
\hline 9 & França & Strasbourg & 20.56 & 73 & Colômbia & Bogotá & 84.12 \\
\hline 10 & Reino Unido & Leicester & 24.47 & 74 & Brasil & $\begin{array}{l}\text { Rio de } \\
\text { Janeiro }\end{array}$ & 86.26 \\
\hline
\end{tabular}


Tabela 3: classificação global das melhores e piores cidades para deslocamento. Fonte: ExpertMarket, tradução nossa.

O estudo aponta que não é somente o Rio a única cidade brasileira com um desempenho ruim. Das oito brasileiras, sete classificaram-se nas 20 últimas, com quatro nas sete últimas, o que evidencia as condições precárias de infraestrutura de transporte e de planejamento urbano. Obviamente o fator tamanho médio da população das cidades brasileiras deve ser considerado, pois as cidades que ocupam os primeiros lugares possuem um adensamento demográfico menor, o Rio possui 6,3 milhões de habitantes, já as sete primeiras cidades francesas somadas possuem um total de 2,9 milhões. No entanto, se compararmos com a Nova Iorque (na 57 posição), que possui 2 milhões a mais de habitantes do que o Rio, ou com São Paulo, onde a realidade urbana é semelhante, porém com o dobro da população carioca, vemos que este não é um fator crucial para explicar o melhor ou pior deslocamento. Partindo dos dados da pesquisa internacional para a escala local da MMRJ, vemos grande similaridade, pois a maior parte dos trabalhadores leva de meia hora a uma hora, como apontam os dados do Censo 2010 elaborado pelo IBGE, como podemos ver no gráfico 8 .

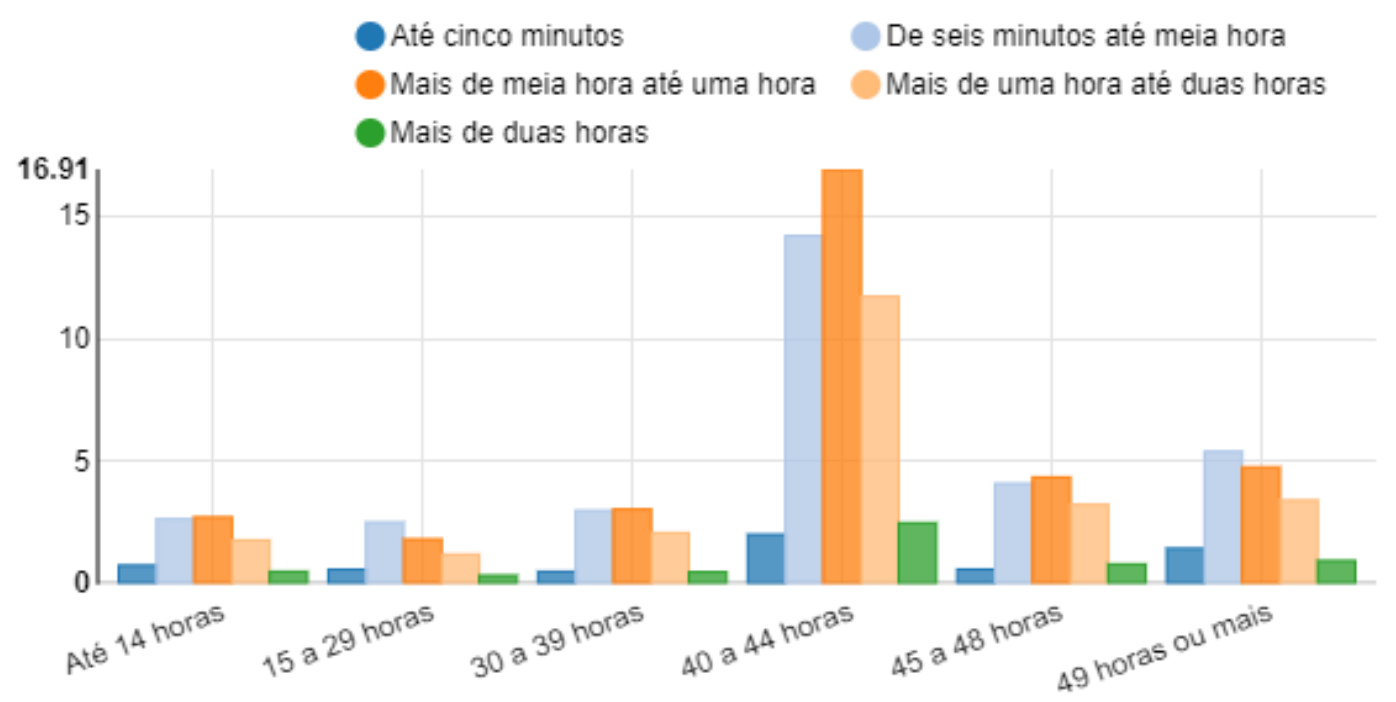

Gráfico 8: Porcentagem de trabalhadores que se deslocam para trabalho na MMRJ por tempo gasto e por faixas de horas habitualmente trabalhadas por semana no trabalho principal. Fonte: IBGE/Censo 2010. Elaborado pela autora.

Essa pesquisa mostrou que há muitas pessoas que trabalham no município de moradia e um número expressivo de deslocamentos intrametropolitanos. Em todas as faixas de horas trabalhadas o deslocamento entre 1 e 2 horas representou um percentual relevante, cerca de $23 \%$ do total de trabalhadores ou 888.845 pessoas, 
sobretudo nos municípios como Japeri e Queimados que possuíam o maior tempo, já que boa parte dos trabalhadores precisam se deslocar. Contabilizando as viagens de ida e volta teríamos cerca de 40 a 80 horas mensais de deslocamento apenas para este grupo de pessoas. Isto sem contar o tempo de espera, o que confirma o resultado mostrado pela agência inglesa. Os deslocamentos abaixo de 30 minutos referem-se principalmente às pessoas que trabalham no local onde residem. Aqueles que levam mais de uma hora residem em municípios da periferia e se deslocam para municípios vizinhos, porém o Rio é uma exceção, é onde encontra-se o maior tempo gasto no deslocamento entre a população que mora e trabalha neste município, indicando que os deslocamentos internos de uma cidade também podem demandar muito tempo.

Nesse ponto vale destacar que o tamanho da cidade não é determinante, pois levando em conta os resultados da pesquisa inglesa vemos que o Rio é menor do que São Paulo e nos dados do Censo 2010 apresentou 7,5\% a mais do tempo médio gasto na capital paulista, sendo a média de deslocamento nacional cerca de 30,2 minutos no ano da pesquisa. Para um morador do Rio, trajetos pequenos podem se tornar mais exaustivos e demorados do que aqueles que se deslocam do Rio para outros municípios ou vice-versa, dependendo do horário e do modal escolhido, por exemplo.

Vários fatores influenciam neste aspecto, o incentivo histórico do rodoviarismo como status social, a construção de metrô e linhas férreas que não abrangem a metrópole e nem a região metropolitana como um todo, a urbanização desordenada que contribuiu para a construção de vias que não necessariamente representam a menor distância entre os bairros residenciais e as áreas produtivas, o crescimento da periferia sem planejamento, o deslocamento parcial de postos de trabalho para estes locais e a maior proporção da PEA em bairros do subúrbio da cidade, como a Zona Norte e Zona Oeste em contraste à maior diversidade e disponibilidade de modais em bairros da Zona Sul e Centro, onde residem um número alto de idosos. Outro aspecto é que cerca de 3/4 trabalha em média 8 horas diárias ou 40/44 horas semanais. Essa rigidez da jornada de trabalho com os mesmos horários de entrada e saída, contribui para ampliação da hora do rush, fazendo com que muitos saiam cada vez mais cedo e outros aguardem até tarde para fugir dos imensos congestionamentos e da superlotação. Isto também contribui por ampliar o tempo de espera, que embora não tenha sido contabilizado no Censo 2010, é tão relevante 
quanto o tempo de deslocamento. É nesse sentido que podemos pensar o tempo de deslocamento como um lugar, pois cada vez mais torna-se presente na vida das pessoas.

Outro ponto importante que explica o péssimo resultado é o custo em relação à renda da população. Os trabalhadores de Nice gastam cerca de 1,3\% do seu salário com deslocamento, contra 9,4\% do salário líquido médio mensal de um carioca, como aponta o estudo. Isto possui grande impacto para os moradores da periferia que diante da maior dificuldade de acesso ao trabalho e da menor disponibilidade de transporte, necessitam muitas vezes utilizar vários modais para chegar ao trabalho o que representa uma fatia substancial da renda familiar ou mesmo os exclui do mercado de trabalho por representar custos para o empregador, e como a lógica que vigora nas metrópoles é de acumulação, a redução destes custos é incorporada ao trabalho. Podemos observar isto no gráfico a seguir de deslocamento para o trabalho na microrregião metropolitana com dados do Censo 2010.

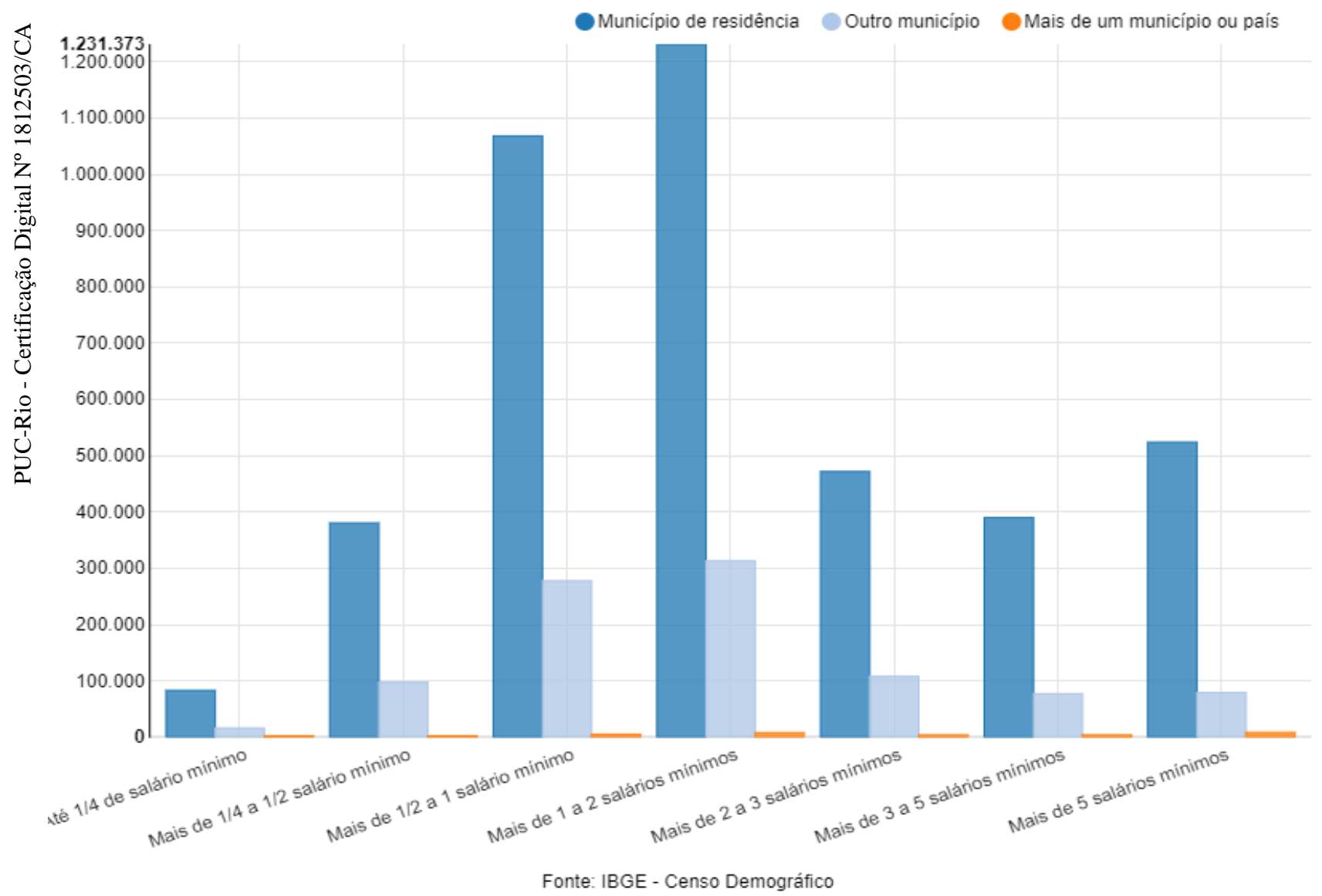

Gráfico 9: Deslocamento para o trabalho na MMRJ por classe de rendimento mensal nominal per capita e local do trabalho principal. Fonte: Sidra- IBGE/ Censo 2010. Elaborado pelo autor. 
Podemos ver que embora a maioria dos trabalhadores pesquisados na amostra tenha como local de trabalho o município de moradia, há um número expressivo daqueles que se deslocam diariamente para outros municípios e que possuem renda média de meio a dois salários mínimos, indicando que o impacto do custo do deslocamento no seu cotidiano pode ser significativo, uma vez que as passagens intermunicipais nesta microrregião apresentam valores mais elevados do que as passagens na metrópole do Rio de Janeiro, que já se mostra alta.

Este alto custo do transporte relaciona-se com o monopólio das empresas de transportes rodoviário na cidade e em todo estado, e pela influência do capital financeiro nas cidades, pois além da especulação gerada nas cidades este financia diversos serviços urbanos, inclusive no setor de transportes. Como exemplo disso temos a principal linha férrea do estado que cruza 12 municípios da região metropolitana. Possui $270 \mathrm{~km}$ de extensão e tem como o principal destino de seus ramais a cidade do Rio de Janeiro. Atualmente está sob concessão da empresa Supervia que a comanda a operação ferroviária intrametropolitana do estado desde 1998, através de contrato com o governo estadual. No ano de 2011 passou a ser controlada pela Odebrecht TransPort e em 2019 foi comprada pela multinacional Mitsui sob o argumento de aumentar investimentos, melhorar a qualidade de serviços e equacionar dívidas. Após a compra da empresa foram feitos reajustes aumentando o valor da passagem e reduziram o número de trens em circulação, aumentando assim o tempo de espera. Assim como ocorre na educação, o transporte também é cooptado pelos interesses privados que investem nestes setores com a finalidade de se obter lucro, sem a preocupação com a qualidade dos serviços.

Desse modo, resgatando o conceito de imobilidade tratado anteriormente, podemos observar que estes indivíduos que gastam muitas horas se deslocando ou aqueles que são impedidos de se deslocar seja pela falta de meios ou pelo alto custo representam uma parcela significativa que se encontra imóvel.

Nosso objetivo com este exemplo não é mergulhar na questão do transporte ou custo do deslocamento, mas a partir disso podemos pensar como a influência global pode gerar diferentes percepções de precarização do espaço e da vida na escala local. Massey (2008, p. 24 e 25) afirma que é na esfera do cotidiano em que as práticas são reais e valorizadas e que se tem a fonte geográfica de significados, no entanto, a autora também afirma que esse local está sob influência de escalas geográficas 
superiores, diz ela: "o global tece suas teias, cada vez mais poderosas e alienantes" (MASSEY, 2008, p.24).

Barbosa (2016) explica que a metropolização da cidade exerce papel definidor de periferias territorialmente expandidas. Para ele em metrópoles de países latinos, o aumento da área urbana significou o aprofundamento da desigualdade socioespacial, retratado principalmente nestas áreas. Ele também afirma que embora o modelo centro-periferia ainda seja presente, ele não é mais uma característica marcante no espaço urbano, pois há centralidades nas periferias e periferias nas áreas centrais.

O mapa abaixo, elaborado com dados do Censo 2010, mostra um exemplo dessa desigual distribuição do trabalho nas cidades. O mapa revela a porcentagem de trabalhadores que necessitam deslocar-se para outros municípios com a finalidade de trabalho. Divididos em três cores, criamos três padrões para diferenciar esses espaços. Os dados do IBGE foram coletados de forma amostral, mas já evidenciam a questão da mobilidade na região.

\section{MOBILIDADE URBANA: Pessoas que trabalham fora do município onde moram}
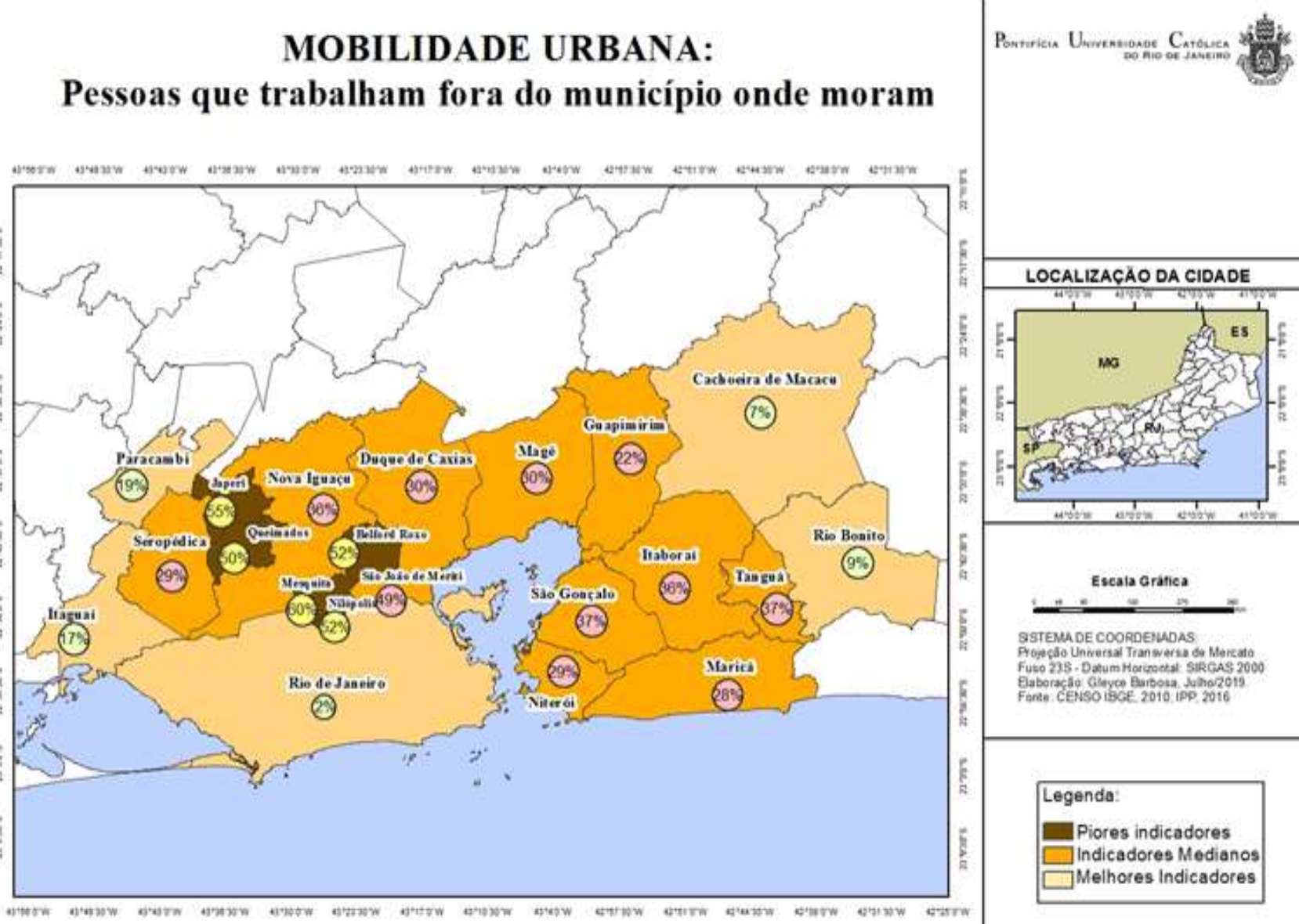

Mapa 2: Pessoas que trabalham fora do município onde moram. Fonte IBGE, adaptado de Casa Fluminense. Elaborado pela autora. 
Os números referem-se ao equivalente absoluto dos trabalhadores, ou seja, as porcentagens referem-se ao total da população que trabalha de cada município. É importante salientar que em termos absolutos $2 \%$ dos trabalhadores do Rio de Janeiro equivalem a um número maior que os 35\% dos trabalhadores de Japeri, por exemplo, ainda assim, os números exprimem que esses fluxos não são iguais e estão submetidos à hierarquia urbana, como elucida Barbosa (2016, p, 174).

Podemos notar que a produção do espaço metropolitano fluminense é marcada pela concentração de investimentos apenas da cidade do Rio de Janeiro, as demais cidades da região metropolitana funcionam como coágulos de alimentação à esta centralidade, proporcionando aos seus habitantes, cotidianos mais exaustivos e degradantes devido à ausência de políticas canalizadas a estender o direito à mobilidade.

Para Barbosa (2016), a metropolização do espaço possui um sentido da diferenciação urbana, porque apenas algumas cidades exercem papéis de imposição de metamorfoses na produção do espaço. Segundo ele: "são espacialidades específicas da metrópole que estão investidas de atos de comando, gestão e financiamento de estruturas corporativas, de instituições governamentais, de organizações sociais e de empresas privadas, que ganham expansão em segmentos do território metropolitano" (BARBOSA, 2016, p. 44).

Isto é estabelecido através de hierarquias espaciais que segundo o autor foram constituídas por processos contraditórios de imposição de centralidades econômicas e políticas, onde o mercado e o Estado exerceram papéis fundamentais na condução da extensão do tecido urbano, completa o autor: "podemos falar, então, de sistemas urbanos complexos que abrigam posições de mando e controle financeiro, produtivo e técnico na tessitura complexa de relações e ações entre cidades" (BARBOSA, 2016, p.44)

Podemos ver esta hierarquia com os dados do Censo 2010 que mostram que do total da população em idade ativa (PEA) da MMRJ quase metade está concentrada na cidade do Rio de Janeiro, 14,4\% em seguido de São Gonçalo e Niterói, 6,3\% em São João de Meriti e 5,8\% em Duque de Caxias. No entanto, na cidade do Rio há pelo menos 2 milhões de pessoas que moram em cidades vizinhas deslocando-se para o trabalho diariamente

Isso explica as diferenciações espaciais no processo acumulação que se propagam também no desenvolvimento urbano impactando assim nos serviços 
disponibilizados para a população. Aqueles que não habitam nestas áreas privilegiadas de investimentos acabam por necessitar deslocar-se até elas ou permanecem excluídos do acesso ao trabalho, estudo, lazer e outros. É nesse sentido entre a localização e distribuição geográfica das ações que a mobilidade se torna central para compreensão da dinâmica urbana, aponta o autor.

Portanto, a metropolização do espaço é determinante para se entender a ampliação e diversificação de mobilidades (BARBOSA, 2016). Para o autor, o que chamamos de metropolização, ou seja, o modo de produzir/gerir e consumir o espaço nada mais é que a mediação entre os fluxos presentes nos arranjos geográficos e a localização dos empreendimentos econômicos. Isto não só engloba os meios que propiciam a circulação, como também envolve gerenciamento de mobilidades em diferentes velocidades.

No mundo contemporâneo, o movimento sobrepôs-se ao repouso, ao fazer da mobilização diária de força de trabalho, capitais e bens uma esfera tão importante quanto à da produção. O domínio e a gestão das escalas espaciais dos fluxos conformam dispositivos que viabilizam a realização de empreendimentos e se tornam, portanto, condição para o modo urbano de reprodução do capital (SANTOS, 1996 apud BARBOSA, 2016, p.45)

Nesse sentido, a mobilidade precisa ser pensada como mobilidades, levando-se em conta as características locais, o contexto de poder local, os lugares, os territórios e o direito à cidade, como definiu Lefebvre (2008). E isto envolve dentre diversas políticas, aquelas que privilegiam a aproximação do trabalho às áreas residenciais. Estas reflexões também se estendem à categoria dos professores, como veremos a seguir. 


\title{
Capítulo 4. Mobilidade e precarização docente na Microrregião Metropolitana do Rio de Janeiro
}

A complexificação e a transformação da organização do espaço permite a coexistência de elementos de diferentes naturezas que produzem diversas formas no espaço urbano. Essas formas são resultantes da tendência econômica de concentração metropolitana com base na economia de aglomeração e da desconcentração das atividades produtivas que avançam sobre as cidades de menor porte, ampliando assim o perímetro conurbado (IBGE, 2016). A pendularidade é um tipo de movimento central para compreender os fluxos mais intensos de caráter econômico que ocorrem nestas aglomerações.

\begin{abstract}
A nova ordem mundial possui como um dos seus traços mais marcantes o deslocamento pendular da população, que acontece na medida em que há uma segmentação entre os locais de residência e emprego. No interior das aglomerações urbanas, ocorre uma expansão que responde a duas lógicas diferentes -a da localização dos empregos nos núcleos das aglomerações e a da localização das moradias-, ampliando as áreas periféricas que abrigam um número cada vez maior de trabalhadores. (IBGE, 2016, p.14)
\end{abstract}

Desse modo, ainda que os deslocamentos para trabalho e estudo ocorram intensamente nas maiores áreas urbanas, isto tem se ampliado para diferentes escalas devido às desiguais ofertas de trabalho e moradia, que não só atingem aqueles que trabalham no setor industrial, devido à localização mais engessada destas atividades, mas também no setor de serviços. Assim, na nova realidade mundial formam-se arranjos de diferentes proporções onde os deslocamentos pendulares exercem papel central na expansão urbana e nas transformações do trabalho, ampliando as aglomerações em rede (IBGE, 2016).

Nesse novo modelo, metrópoles como São Paulo (SP) e Rio de Janeiro (RJ) estão sendo refuncionalizadas como centros de serviços avançados na nova divisão internacional do trabalho. Outras concentrações urbanas do País também registram aumento de importância de serviços e a presença de produtos industrializados mais aprimorados (IBGE, 2016, p.15)

O IBGE aponta que quase todas as grandes aglomerações e capitais estaduais reduziram o ritmo de crescimento entre as décadas de 1970 a 2010, exceto Rio de Janeiro (RJ) e Brasília (DF), que aumentaram entre 1991 e 2000. O órgão afirma que a pendularidade cresce hoje em um ritmo mais acelerado do que o próprio crescimento populacional. Além disso, podemos relacionar a tal processo a 
expansão dessas novas formas de trabalho que ampliam a circulação de trabalhadores em busca de aumento de seus ganhos. Com os professores não foi diferente, por estarem regulamentados por regimes de trabalho baseados em hora/aula, muitas vezes em horário parcial acabam por ampliar seus vínculos empregatícios e dessa forma criam diversos fluxos no espaço. E como a localização das escolas não obedece necessariamente à mesma lógica de outras atividades produtivas, o desenho espacial criado a partir dos deslocamentos dos profissionais torna-se parcialmente diferente do padrão de pendularidade dos demais trabalhadores, mas ainda assim participa do emaranhado de fluxos presentes na região metropolitana e endossa a complexidade que é desvendar essas redes estabelecidas nas concentrações populacionais. Portanto, neste capítulo abordaremos a relação da mobilidade e da precarização do trabalho docente na MMRJ.

\section{1 $O$ perfil docente e as condições de trabalho na MMRJ}

Quando se fala em trabalho docente, nos referimos à uma função que possui forte caráter interativo e exige alto um investimento pessoal para garantir que haja um envolvimento do aluno no processo, a fim de despertar seu interesse e participação. Além disso, é uma função dotada de grande influência de aspectos econômicos, psicológicos, técnicos, culturais, éticos, políticos, institucionais, afetivos, estéticos, dinâmicos, interativos (PASSOS, 2002).

Se de um lado existem elementos em comum com outras funções do setor de serviços, de outro lado também existem elementos específicos; trata-se de um trabalho imaterial (SAVIANI,1987), em que não é apenas o produto ou o local onde o exerce que importa, mas sim engloba todos os acontecimentos do cotidiano. A profissão docente coloca fatores como juízos de valor, ética, moral, personalidade, estado físico-psicológico, escolhas, interesses, direitos e privilégios a exercerem papel central no andamento de sua função (PASSOS, 2002).

De modo que tais fatores são produtos construídos ao longo do tempo e do espaço vivenciados por estas pessoas, que por sua vez irão influenciar diversas outras mentes e gerações, mostrando assim a demasiada importância e complexidade destes profissionais na construção social. Função esta que nos últimos anos assiste 
a um gradual processo articulado de precarização afetando diretamente o trabalho em sala de aula e na sua própria qualidade de vida.

Para compreender a dinâmica e organização espacial do trabalho docente na escala aqui adotada, como os fluxos interescolas somados à mobilidade casa-trabalho, buscou-se através dos dados oficiais disponibilizados pelo INEP traçar um breve panorama da educação atual no Brasil e na Região Metropolitana do Rio de Janeiro. Isso nos ajudou a compreender os processos que permeia a mobilidade.

Dessa forma, encontramos um total de 52.536 docentes, desse total 32.245 apareceram uma única vez por unidade escolar indicando se tratar de professores que atuam em apenas uma única escola ou que além das turmas de nível médio e fundamental II, também atuam em outras escolas/turmas das categorias não contempladas na seleção como anos iniciais, educação especial, cursos técnicos e profissionalizantes. E encontramos 20.430 docentes atuando em duas ou mais escolas, o que representa $13 \%$ dos professores do estado ou $36 \%$ dos professores que atuam na microrregião metropolitana do RJ.

Antes de avançarmos na escala escolhida, consideramos importante coletar alguns dados sobre os professores brasileiros, a fim de conhecer a realidade na qual também estão inseridos os docentes fluminenses. A tabela a seguir mostra um resumo sobre a profissão na escala nacional, tendo como base o último censo, mostrando que ainda há professores com formação incompleta, sobretudo, aqueles que atuam nos anos finais do ensino fundamental. Já aqueles que atuam no ensino médio a proporção de professores com ensino superior é próxima a 100\%. A maior parte está em contrato permanente, porém menos da metade trabalha em horário integral, o que mais uma vez denuncia a possibilidade de acúmulo de escolas.

\begin{tabular}{|l|l|}
\hline \multicolumn{2}{|c|}{ Resumo do perfil docente brasileiro - Censo Escolar 2018 } \\
\hline № de docentes & 2,2 milhões \\
\hline Sexo & $71 \%$ mulheres \\
\hline Média de idade & 40 anos \\
\hline Experiência & Média 14 anos \\
\hline Tipo de vínculo & $\begin{array}{l}77 \% \text { empregado em contrato permanente. 215 de contratos } \\
\text { temporários só nas redes estaduais e 17\% nas municipais }\end{array}$ \\
\hline Contrato integral & $40 \%$ empregados \\
\hline № de escolas & $78 \%$ apenas uma e 22\% em duas ou mais \\
\hline Hora aula & $\mathrm{R} \$ 14,23$ (média nacional) \\
\hline
\end{tabular}

Quadro 10: Resumo diagnóstico sobre o trabalho docente no Brasil. Dados: Censo escolar 2018. Fonte: elaboração própria 
Quando se fala em professores que atuam em duas ou mais escolas, essa proporção tende a ser maior sobretudo em relação aos que atuam no ensino médio. A rede estadual é a que possui a maior proporção de contratados temporários comparado ao total de contratados das escolas públicas de outras redes. Além disso, a hora aula daqueles que atuam nos anos iniciais provou ser muito inferior à de professores do ensino médio, que também não possuíam hora-aula acima da média do piso nacional.

A história docente brasileira mostra que a disseminação das escolas pelo país está relacionada também à história do trabalho feminino no país. Isto porque em sua origem e popularização no Brasil como uma profissão de massa existia um estigma de que uma função não profissionalizante e formadora para obediência deveria estar atrelada ao sexo feminino. Com a profissionalização eleva-se a quantidade de homens buscam a carreira, mas ainda predominando a desigual proporção entre os gêneros. Podemos observar isto na pirâmide etária a seguir que mostra a relação gênero-idade da microrregião metropolitana do Rio de Janeiro.

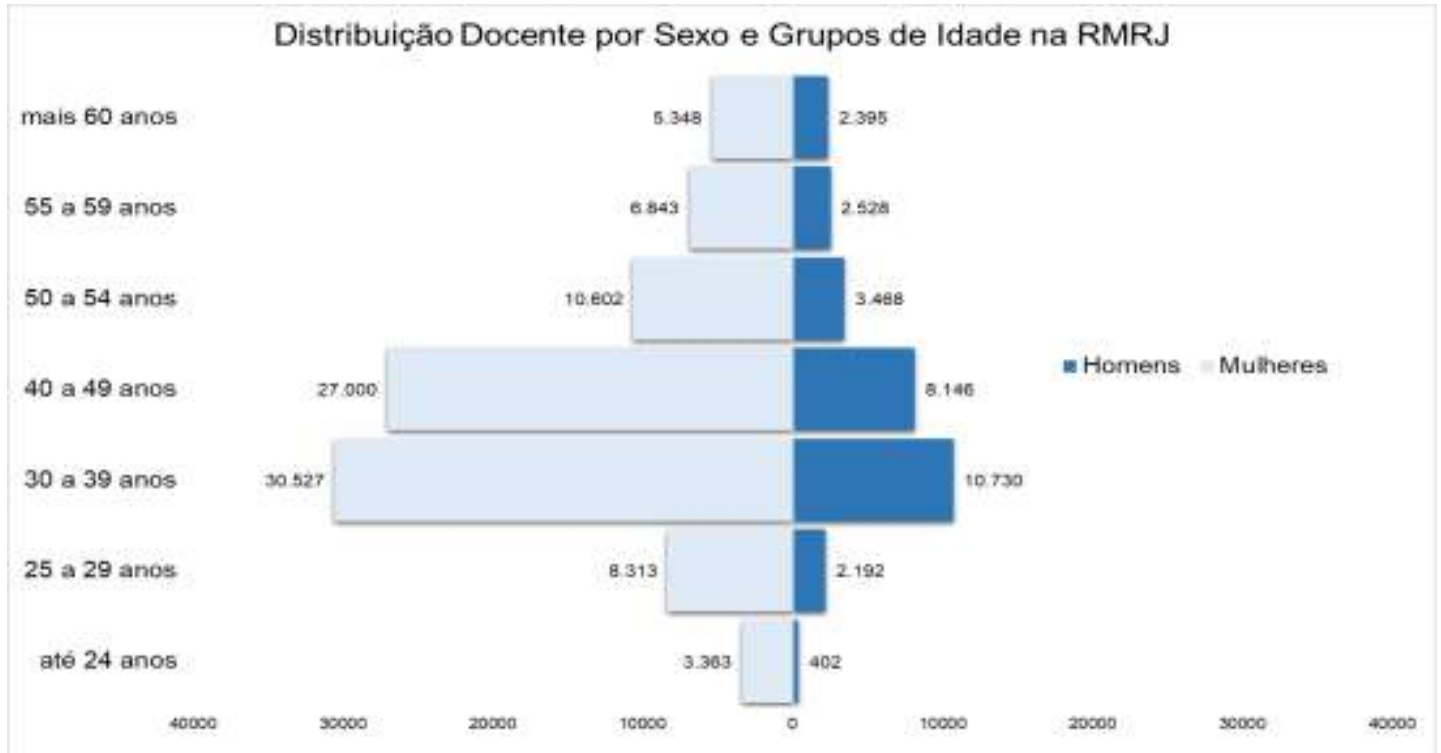

Gráfico 10- Pirâmide etária docente na RMRJ 2018. Dados Censo Escolar 2018. Fonte: elaboração própria.

Como podemos ver, esta realidade não mudou muito, a docência básica no Brasil ainda continua sendo ocupada principalmente por mulheres e quando se trata de ensino fundamental (anos iniciais) essa disparidade é ainda maior. Desse modo, a percepção que esses indivíduos possuem em relação ao trabalho que desempenham não é a mesma, vide que a maior parte das mulheres convive com a dupla jornada 
em seu cotidiano, casa-trabalho e agravada pelo trabalho polivalente e em diversas escolas.

Além disso, quando olhamos para a faixa etária, percebemos que a docência está envelhecendo, não só por conta da transição demográfica na qual vive o país, mas também pela recente redução em contratação efetiva de professores, o que gerou carências nas escolas, sobretudo públicas. A reforma da previdência aprovada em 2019 (BRASIL, 2019) irá afetar uma grande leva de professores. A nova proposta, propõe a aposentadoria com base em um sistema híbrido que leva em conta a idade e o tempo de contribuição ou a idade e um sistema de pontos. Segundo a nova regra, professores homens terão aumento de cinco anos na idade mínima para aposentadoria e mulheres sete anos, 60 e 57 anos respectivamente. Porém, o tempo de contribuição permaneceu o mesmo para as mulheres e reduziu em cinco anos para os homens, ficando ambos com no mínimo vinte e cinco anos de contribuição. E para os professores que atuam na rede pública será necessário ter completado no mínimo dez anos no serviço público e cinco anos no último cargo. Apenas homens com mais de 56 anos e meio e com mais de 30 anos de contribuição ou mais de 82 pontos, e mulheres com mais de 51 anos e meio que tenham contribuído com mais de 25 anos poderão utilizar o sistema de transição.

Todavia, esta Emenda Constitucional (BRASIL, 2019) também prevê que este tempo de contribuição não diz respeito ao salário integral. O benefício será de $60 \%$ da contribuição para aqueles que trabalharem por 20 anos, acima disso acrescenta $2 \%$ anualmente do valor da contribuição, ou seja, só chegará à $100 \%$ do salário aqueles que contribuírem por 40 anos. Na prática, significa dizer que comparado ao antigo sistema, os professores terão que trabalhar 10 e 15 anos a mais (homens e mulheres, respectivamente) para receber seu salário integral.

Este tipo de reforma é colocado como uma política de austeridade necessária para manutenção das contas públicas, mas esconde privilégios concedidos a determinados grupos que poderão usufruir do benefício da aposentadoria de forma integral, além de seus altos salários possibilitarem a obtenção de renda através de investimentos, sem contar herança e outras fontes. Realidade esta que não inclui a maior parte da população brasileira, que obtém renda somente através do trabalho. Assim, a tendência da reforma será culpabilizar o indivíduo que não conseguir alcançar uma estabilidade financeira na velhice, empurrando aqueles que possuem 
algum excedente para a complementação da renda através de investimentos e previdência privada.

Analisando superficialmente, já que não é nosso objetivo aqui adentrar nas minúcias do documento, podemos perceber que a principal perversidade da reforma não está no aumento do tempo de trabalho e nem do mínimo exigido para contribuição, mas principalmente na base de cálculo que reduz em $40 \%$ o salário atual. Como efeito disso, teremos um agravamento da pobreza, sobretudo entre os mais idosos e possivelmente a ampliação da desigualdade no país. Com relação aos professores, é possível que diante do cenário atual de precarização, o prolongamento da carreira acarrete aumento no número de pedidos de licenças por problemas de saúde.

Além disso, é provável que o número de jovens docentes desempregados e informais seja maior, pois com o aumento dos anos de trabalho, a reposição da mão de obra será mais lenta, diante do volume de formandos em licenciatura que temos hoje no país. Além de outros impactos indiretos, é possível que continue aumentando o acirramento das vagas ao mesmo tempo que aumenta o número de profissionais mais qualificados, mas isto não significa que vem acompanhado de aumento salarial, vide outros problemas que falamos anteriormente, como cortes de verbas no setor e por conta da própria estrutura do sistema capitalista em que numa situação de excedente de mão de obra reduz salários e direitos trabalhistas.

Outra questão a ser discutida é esfacelamento atual do pleno emprego, contribuindo para dificultar essa aposentadoria, uma vez que diante de todo este cenário de aumento da terceirização, contratação temporária, redução de concursos, surge a indagação de quantos conseguirão trabalhar por 40 anos sem parar e poderão se aposentar com salário integral? Ou mesmo, quantos atingirão o mínimo de 25 anos em um emprego formal para se aposentar com $60 \%$ da contribuição?

Outra questão que os dados revelam redução da reposição dos professores, que tiveram seu ápice de abertura de concursos nos anos 1990 e na primeira década de 2000, vide o resumo técnico do censo escolar (BRASIL, 2018) que aponta uma média de 14 anos ou mais de experiência na função, ou seja, professores que entraram neste período. Atualmente, o número de trabalhadores em situação efetiva é maior do que em situação temporária na rede pública. O gráfico a seguir mostra claramente maior concentração de professores na rede pública e o outro permite um comparativo entre as redes e entre as os regimes de contratação. 


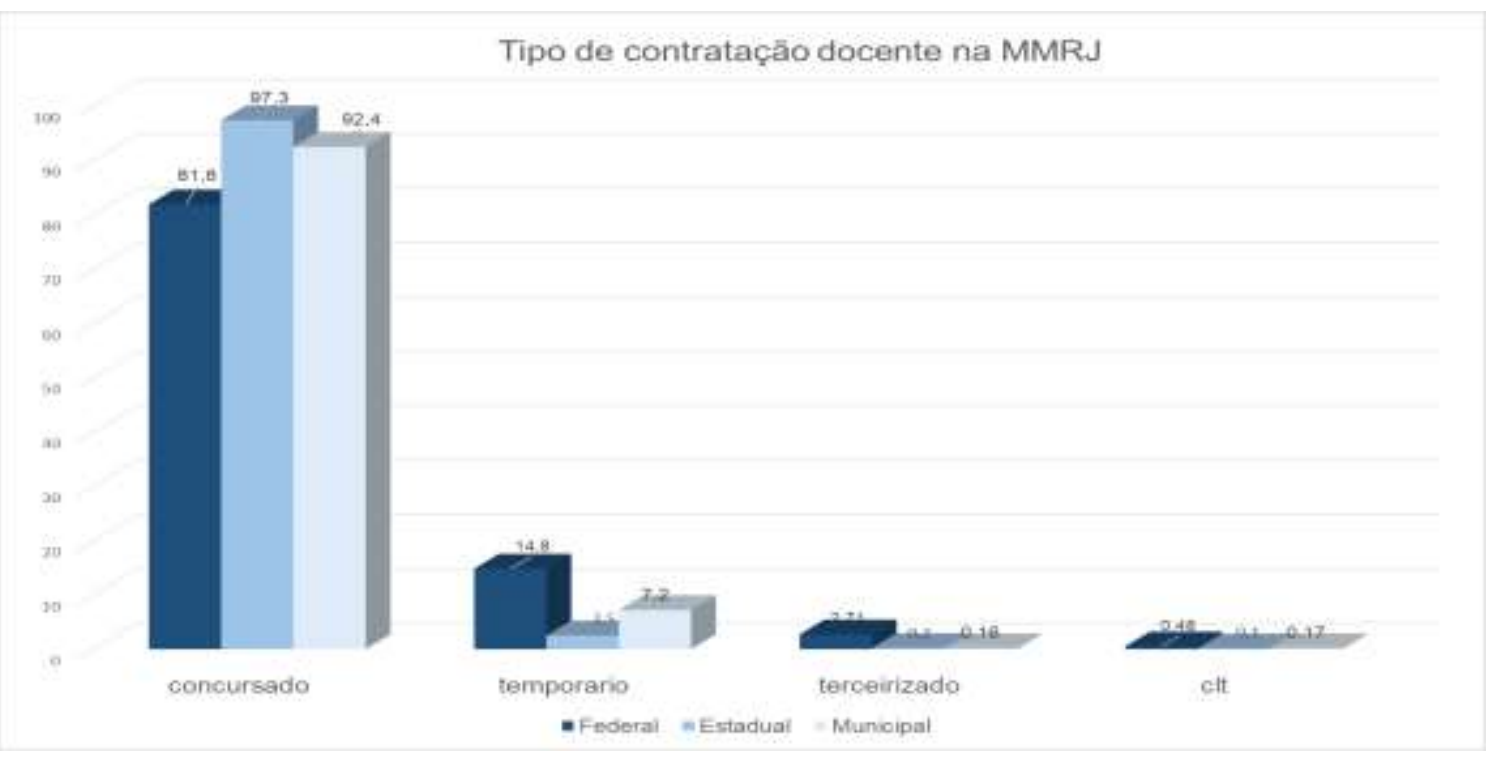

Gráfico 11: Tipo de contratação na RMRJ. Dados: Censo Escolar 2018. Fonte: elaboração própria.

Quanto à esfera privada, o censo não mostra dados sobre os regimes de contratação. É importante frisar que os dados englobam da educação infantil ao médio, no somatório dos resultados municipais dos 16 municípios que compõem a região metropolitana do RJ. Portanto, tem-se hoje duas realidades: professores em idade mediana com cargos efetivos, porém uma pequena parte não empregada em tempo integral e com regimes de horas diferenciados, o que pode levar a um grave problema percebido no cotidiano referente ao acúmulo de escolas para suprir uma renda deficitária. E por outro lado, temos professores mais jovens com dificuldades de inserção formal no mercado, sobretudo por conta da implementação gradual das reformas trabalhistas.

Tipo de contratação na MMRJ

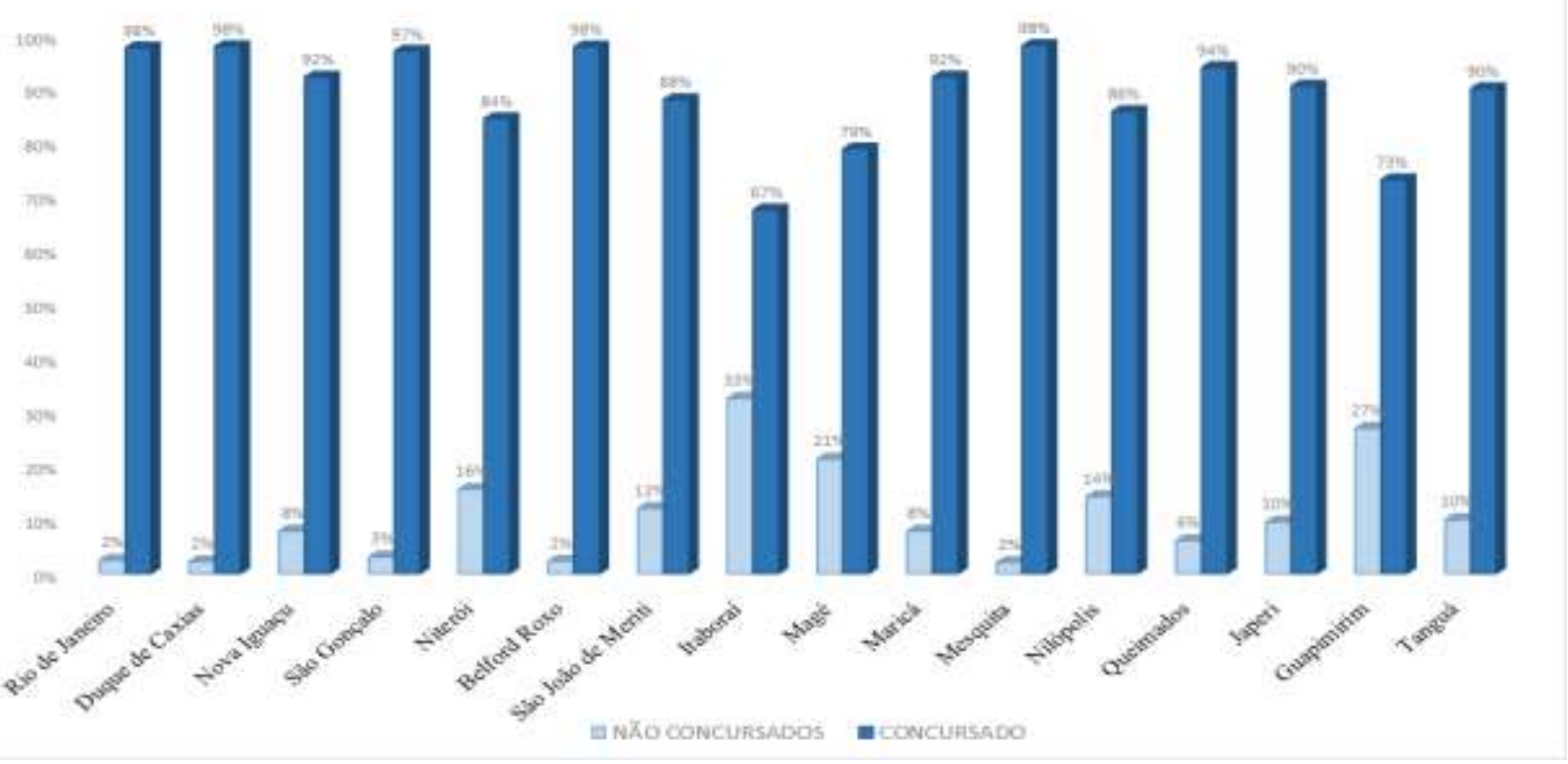


Gráfico 12: Comparação dos municípios da Região Metropolitana por tipos de contratação. Dados: Censo Escolar de 2018. Fonte: elaboração própria

O gráfico acima leva em consideração o somatório das três esferas públicas de cada município separando a categoria dos concursados e não concursados (temporários, terceirizados, CLT). Chama atenção os municípios menos populosos e mais afastados da metrópole, como Itaboraí e Guapimirim, que apresentam quase a metade do número de professores que atuam nas esferas municipal, estadual e federal na condição de contratados, o que indica forte instabilidade, uma vez que entendemos o emprego estável como uma das formas que permite ao trabalhador obter maior segurança no trabalho.

Além disso, são municípios que conforme mostrado no mapa 1, não apresentam integração com a metrópole (RJ), indicando que a maior parte das pessoas que residem nestes locais trabalha no próprio município, possivelmente pela debilidade da rede de transportes. Isto agrava a situação dos professores locais, pois a ausência de estabilidade não é necessariamente compensada em municípios vizinhos. Outro ponto é que Itaboraí não é um município de economia insignificante na RMRJ, ao contrário, com o início das obras do Complexo Petroquímico do Rio de Janeiro, o Comperj, em 2008 - o maior empreendimento da Petrobrás - o município atraiu vários investimentos e empresas. Apesar da obra ter sido paralisada em 2015, o município já contava com este quadro de docentes temporários, algo que se agravou após o ocorrido, sem a abertura de novos concursos até o presente momento (2020), vide pesquisa realizada no site da prefeitura e sites de concursos, sem nenhum resultado encontrado após o ano em questão. Também foram os municípios que apresentam nos microdados do Censo Escolar, o maior número de professores na situação CLT e terceirizados.

Este cenário de diminuição de vagas formais e de concursos para os professores é uma pequena fatia do que representa o crescimento da precarização do trabalho no país. Conforme dados da PNAD contínua (IBGE, 2020). Em 2018 e 2019 a taxa de de desocupados no estado do Rio de Janeiro atingiu o índice de 14,8\% e 13,7\%, respectivamente, Além do crescimento de $32 \%$ na taxa de subocupação por insuficiência de horas trabalhadas nesse mesmo período, ou seja, pessoas ocupadas com uma jornada inferior a 40 horas semanais que gostariam de trabalhar por um período maior, conforme definição do IBGE. Revelando a aceleração de deterioração do emprego em um curto período. Ao mesmo tempo a região 
metropolitana acompanhou um vertiginoso aumento da uberização do trabalho, onde aplicativos que eram complementos à renda formal tornaram-se a única ou principal fonte de muitos destes trabalhadores.

Obviamente essa mudança impacta diretamente o deslocamento destas pessoas, pela redução do volume de trabalhadores se deslocando para o trabalho formal em ritmo e horário pré-determinados, pelo aumento da circulação dos trabalhadores informais em ritmos, espaços e horários diferenciados ou pela imobilidade dos chamados desalentados, ou seja, aqueles que por estarem há tanto tempo fora do mercado de trabalho desistiram de buscar emprego e encontram-se imóveis, muitos sem renda até para arcar com os custos de deslocamento. Este processo atinge em maior ou menor grau todas às áreas do setor de serviços. No entanto, outra tendência pode ser percebida nessas áreas metropolitanas, o crescimento da informalidade e das formas precárias de contratação abordadas aqui anteriormente como o trabalho parcial, intermitente e outros que possuem relação direta com o aumento dos fluxos no território.

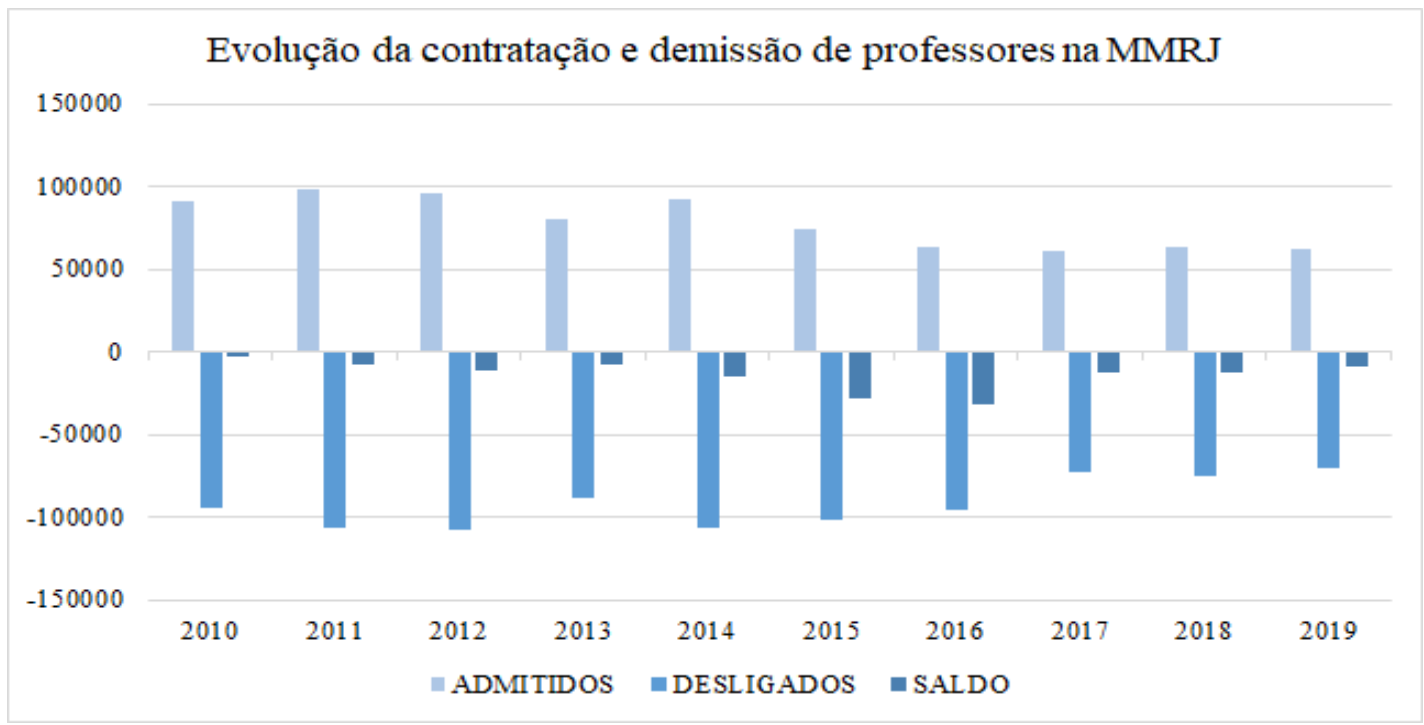

Gráfico 13: evolução da contratação e demissão na MMRJ. Fonte: CAGED/MTE (2020). Elaborado pela autora.

Notamos um considerável aumento do desemprego representado por um saldo negativo de 138.539 vagas, ou seja, postos de trabalho que simplesmente deixaram de existir ao longo da última década. Isto não só se relaciona ao aumento dos pedidos de aposentadoria e a redução de concursos na rede pública, mas também com o aumento de demissões na rede privada. Porém o gráfico a seguir mostra que na contagem das Sinopses Estatísticas da Educação Básica (BRASIL, 2010 a 2019), uma espécie de compilação dos microdados do Censo Escolar, o número de 
docentes vinculados à rede privada não se alterou, pelo contrário, aumentou entre os anos 2010 e 2014. E como o censo não monitora os vínculos empregatícios da rede privada, apenas contabiliza o número de docentes, nos leva a crer que diversos postos de trabalho formais foram fechados, ao mesmo tempo que algumas dessas redes adotaram formas de contratação flexíveis, como MEI e outras.

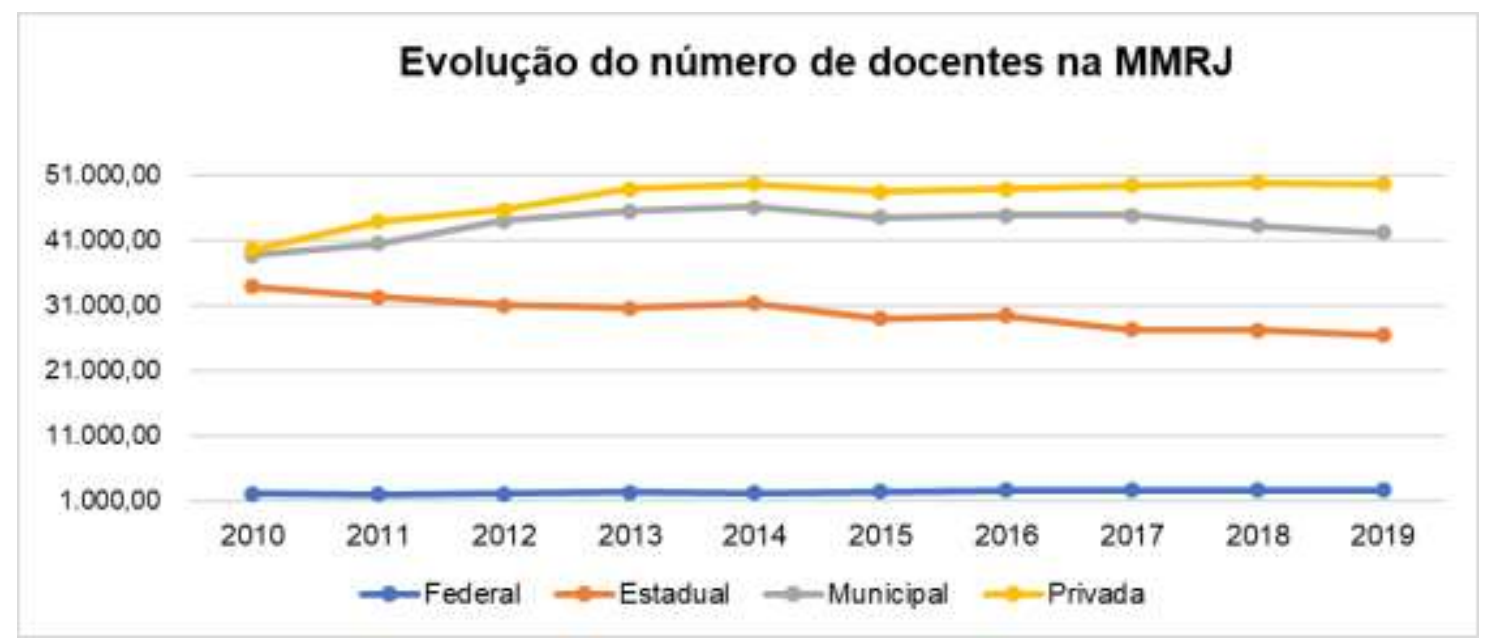

Gráfico 14: Evolução do número de docentes na MMRJ (somatório dos anos finais e ensino médio). Fonte: Sinopses Estatísticas da Educação Básica/ Censo Escolar (2010 a 2019). Elaborado pela autora.

Além disso, podemos dizer que estas novas formas de contratação precárias na rede privada podem estar relacionadas às grandes redes de ensino, pois nos últimos anos com a criação de holdings educacionais, estas passaram a disputar e monopolizar a educação básica no território fluminense, comprando diversas escolas particulares de médio e pequeno porte ou causando a falência destes estabelecimentos devido ao acirramento do mercado.

No gráfico podemos observar que até o ano de 2014 havia uma tendência ascendente de contratação de professores nas redes municipais e privada relacionada ao momento econômico do estado e a realização de concursos. No entanto, a rede estadual já mostrava debilidade quanto à reposição dos docentes, reduzindo vagas ao longo de toda década, o que se deve ao fechamento de escolas como já abordado neste trabalho e a tendência ao sucateamento da rede, o que também se verificou na rede municipal a partir de 2017. Isso se verificou em relação ao número de matrículas, como podemos ver a seguir. 


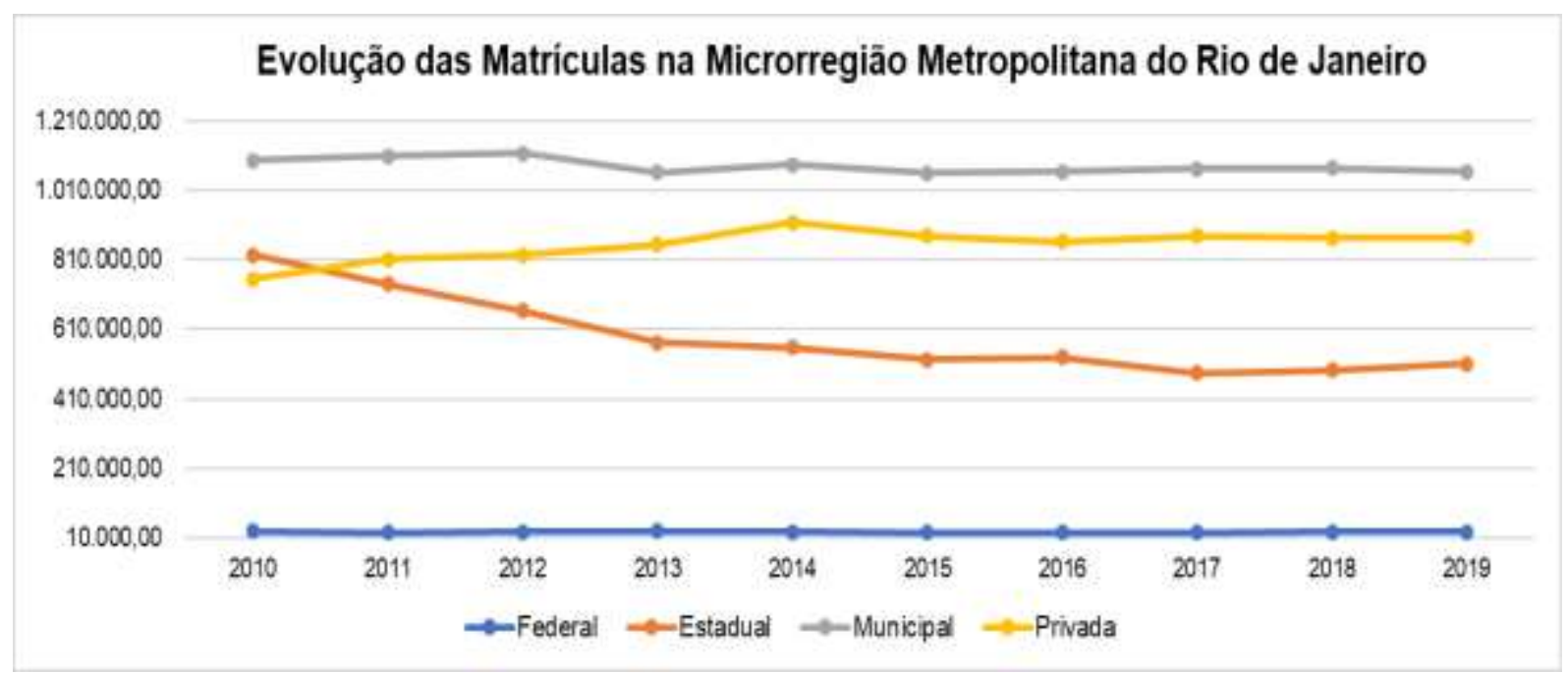

Gráfico 15: Evolução do número de matrículas na MMRJ (somatório dos anos finais e ensino médio). Fonte: Sinopses Estatísticas da Educação Básica/ Censo Escolar (2010 a 2019). Elaborado pela autora

Assim como ocorre com os docentes também pode-se notar a ampliação de alunos na rede privada, atrelada ao aumento de cursos preparatórios, superlotação de turmas e fechamento de vagas na rede pública. Outro aspecto é que a tendência de alunos saindo da rede pública para as escolas privadas observado entre 2010 e 2014, pode estar relacionada ao aumento da renda familiar naquele período, a situação estigmatizante em torno da educação pública e a redução da taxa de fecundidade que ampliou a possibilidade de excedente de renda. Isso tem impacto direto no aumento da demanda de professores na rede privada, como vimos nos gráficos anteriores.

É bom salientar que apesar da rede privada apresentar grande número de docentes, este número não é superior ao somatório das redes públicas, nem em unidades escolares e nem em volume de alunos. Assim, os resultados nos levam a crer que grande parte dos docentes incorporados à rede privada nos últimos anos referem-se à mão de obra jovem recém formada, que pela redução dos concursos passou a ser absorvida por este segmento e isso pode corroborar com a redução de salários. Outra inferência é que o fechamento dos postos de trabalho apontado pela RAIS e o aumento dos docentes vinculados à rede privada apontado pelo Censo mostram o aumento do trabalho informal.

A RAIS iniciou a contabilização destas formas flexíveis de trabalho em 2017. Levando em consideração somente a categoria dos professores da educação básica da MMRJ, ela apresenta os seguintes resultados para o trabalho parcial: em 2017 eram 5.889, em 2018 eram 9.551 e em 2019 já alcançavam a marca de 34.775, 
lembrando que esta fonte está em constante aperfeiçoamento e ainda não contabiliza todos os trabalhadores.

O mesmo ocorre em relação ao trabalho intermitente, ou seja, aquele profissional que trabalha de forma esporádica, sem vínculo empregatício, porém prontamente disponível para a empresa. Fazendo o mesmo recorte na RAIS encontramos 197 professores em caráter intermitente no ano de 2017, 4.096 em 2018 e 12.167 em 2019. Desse modo, notamos a influência da agenda neoliberal nos estados e municípios, diluindo o papel do poder público no provimento da educação pública de qualidade, diminuindo as contratações efetivas, terceirizando, ou mesmo abrindo espaço para crescimento do setor privado de educação.

Além disso, podemos apontar consequências diretas dessas mudanças nas escolas, sem reposição da mão de obra na rede pública, sobretudo estadual, aumenta-se o número de alunos por professor provocando a superlotação de turmas, como podemos ver no indicador de esforço docente da MMRJ.

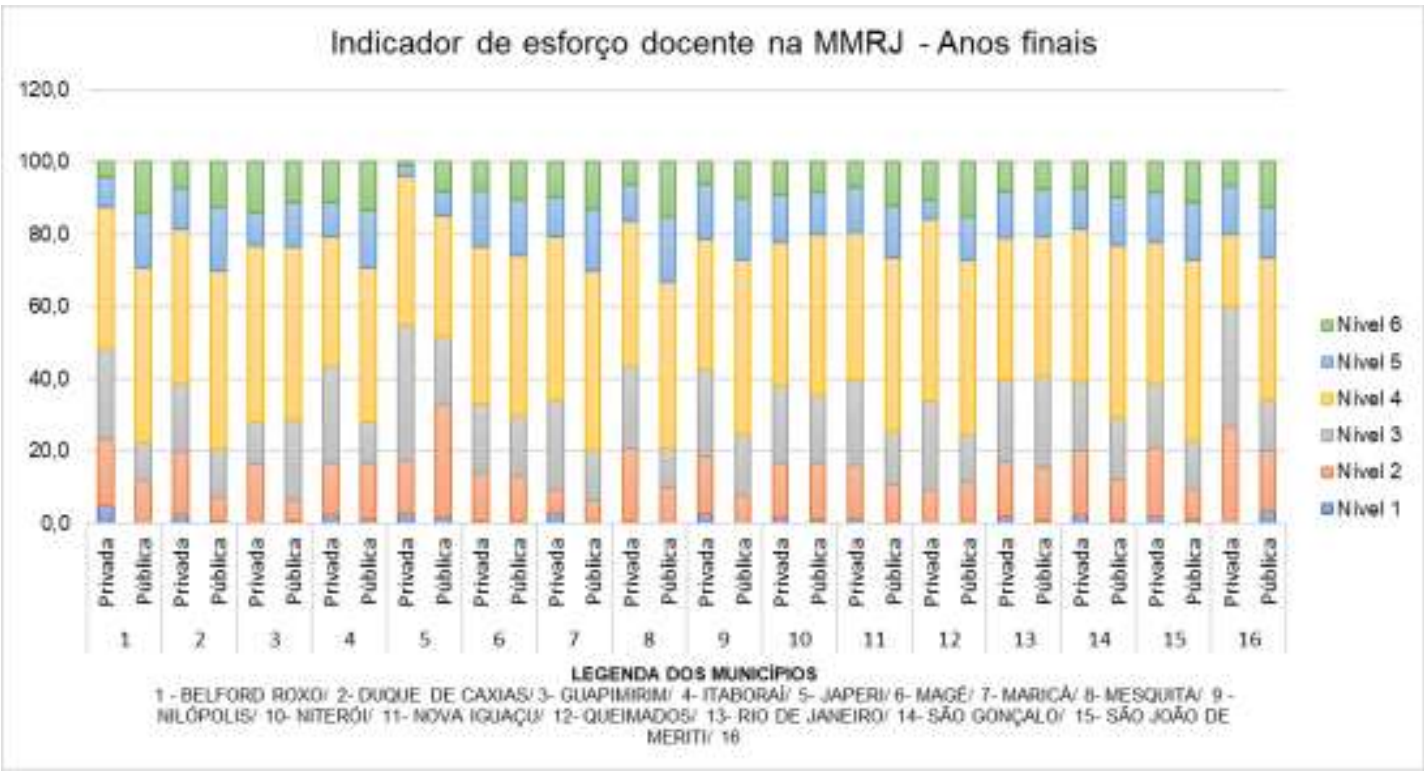

Gráfico 16: indicador de esforço docente na MMRJ - anos finais. Fonte: Saeb/ Painel Educacional. Elaboração própria

Assim como mostrado anteriormente no panorama estadual, na região metropolitana há a mesma tendência de maior número de alunos por professor no ensino médio. Também notamos que a rede privada segue o padrão similar a rede pública, o que desmente a pesquisa da EAG que mostrava que o número de alunos por professor na rede privada era bem menor do que na rede pública. Como mostra o gráfico 16. Vale dizer que as informações da legenda (nível 1 ao 6) estão descritas na metodologia, quadro 4 . 


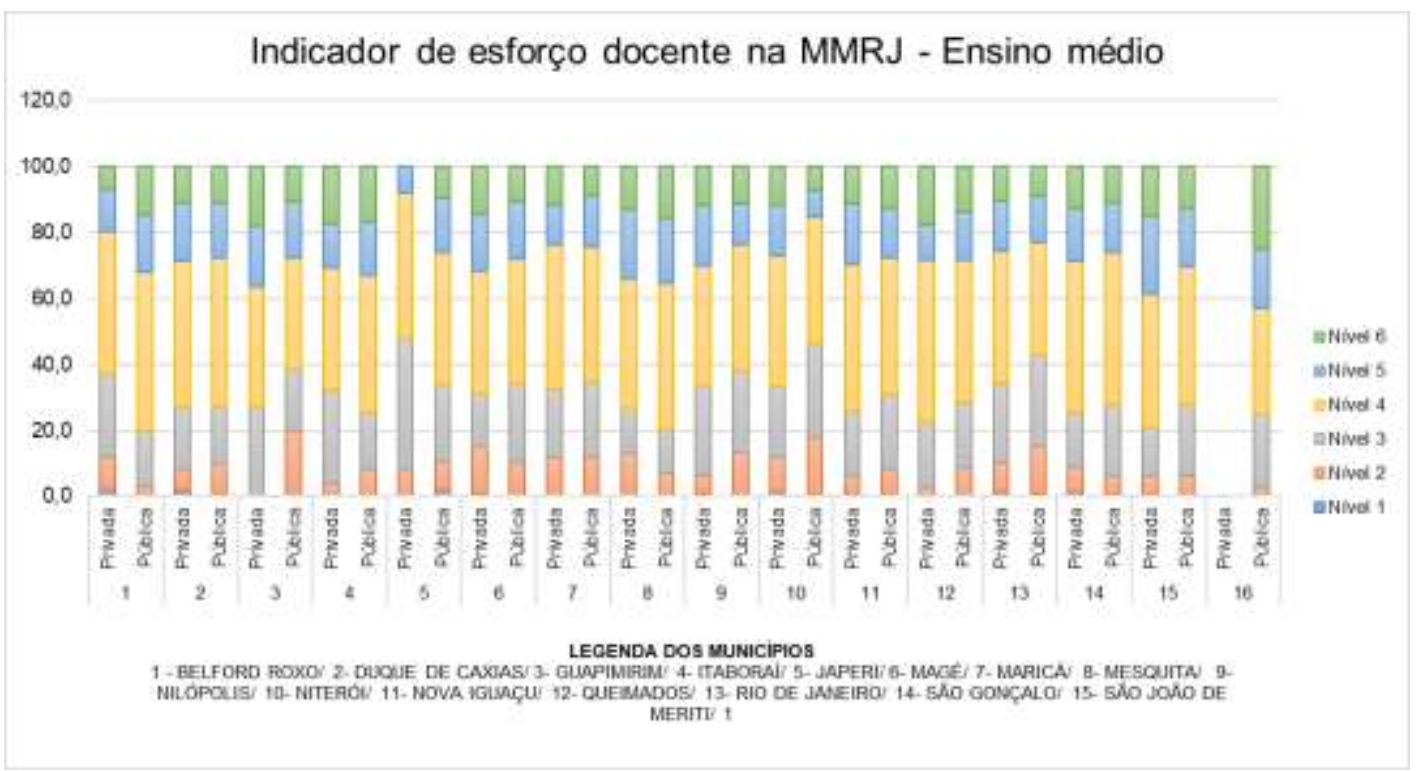

Gráfico 17: indicador de esforço docente na MMRJ - ensino médio. Fonte: Saeb/ Painel Educacional. Elaboração própria

Como podemos notar, há grande sobrecarga de alunos por professor no ensino médio, predominando o nível 4 em quase todos os municípios, ou seja, professores que atuam com 50 a 300 alunos em dois turnos e em uma ou duas escolas. Tendo em vista que a maioria dos professores do ensino médio possuem habilitação para lecionar nos anos finais do ensino fundamental, esta realidade de precarização não se limita a este ou aqueles segmentos da educação básica. Além disso, com a Reforma do Ensino Médio (Lei nº 13.415/2017), a organização curricular por áreas e a não obrigação de oferta de determinadas disciplinas por série, a tendência é de que os docentes do ensino médio tenham cada vez mais seus tempos de aula diluídos em diversas escolas e se amplie as diferenças salariais e de condições de trabalho entre os professores de disciplinas obrigatórias e aquelas que se transformaram em eletivas.

A questão salarial também é importante, pois ela mostra a precarização para além do tipo de vínculos. Nesse sentido, para entendermos a relação salarial é necessário pensar o que determina o valor de uma mercadoria (MARX, 2010, p.36, 37 e 38). A concorrência, a demanda e a disponibilidade de certo produto, a técnica empregada, sua utilidade são algumas das variáveis que definem se a mercadoria terá muito ou pouco valor.

Para visualizar a evolução salarial dos docentes da MMRJ utilizou-se os dados da RAIS sobre a remuneração daqueles que atuam na educação básica. 


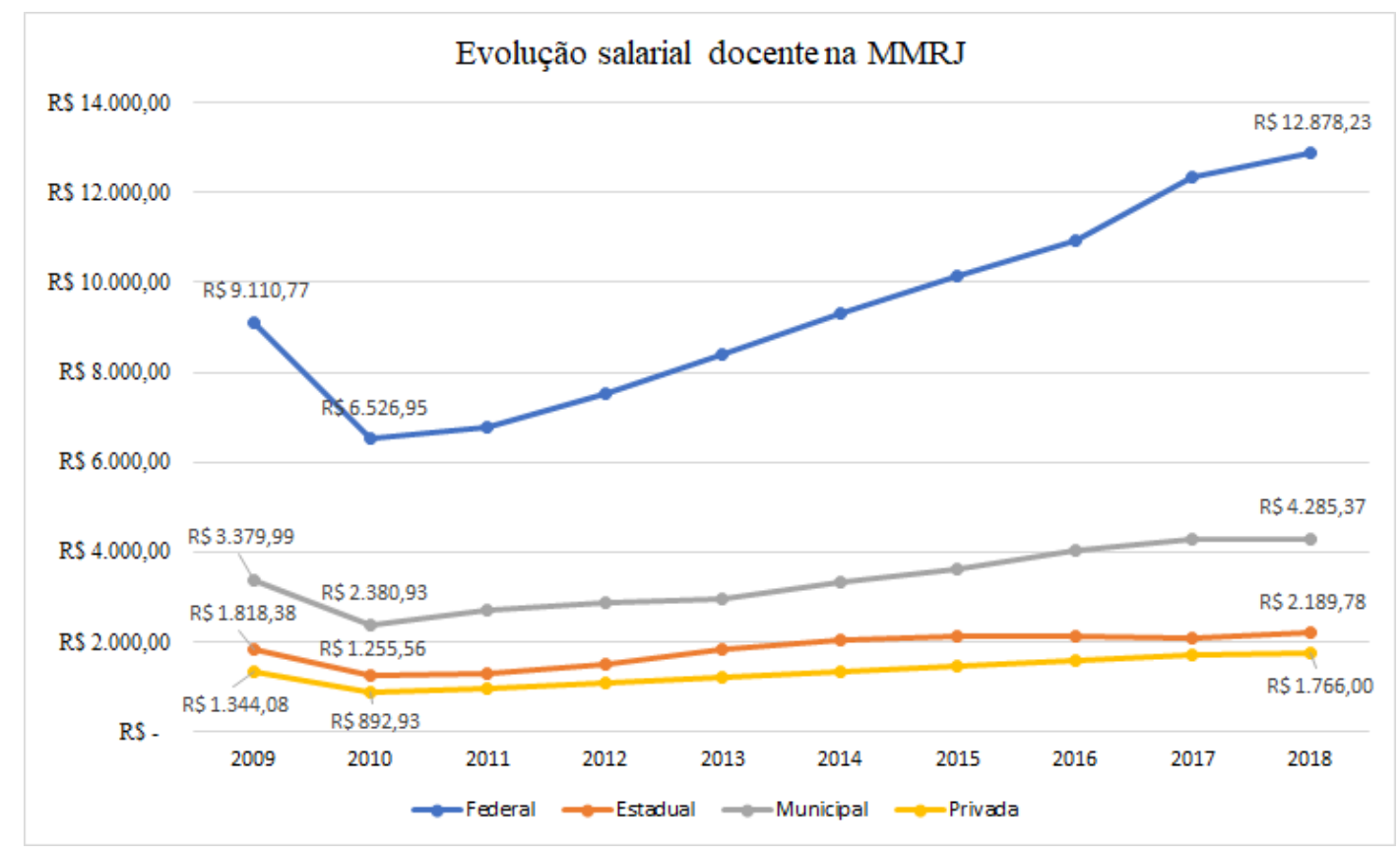

Gráfico 18: Evolução salarial de professores na MMRJ. Fonte: RAIS- MTE/2018. Elaborado pela autora.

Nota-se que em todas as esferas administrativas houve uma redução da média salarial no ano de 2010 como reflexo da crise econômica global de 2008. Também percebemos novamente que a rede estadual e a privada foram as que permaneceram sem reajustes. Para visualizarmos o aumento salarial real utilizou-se a comparação com o valor da inflação do ano anterior (INPC-IBGE), como mostra o gráfico abaixo:

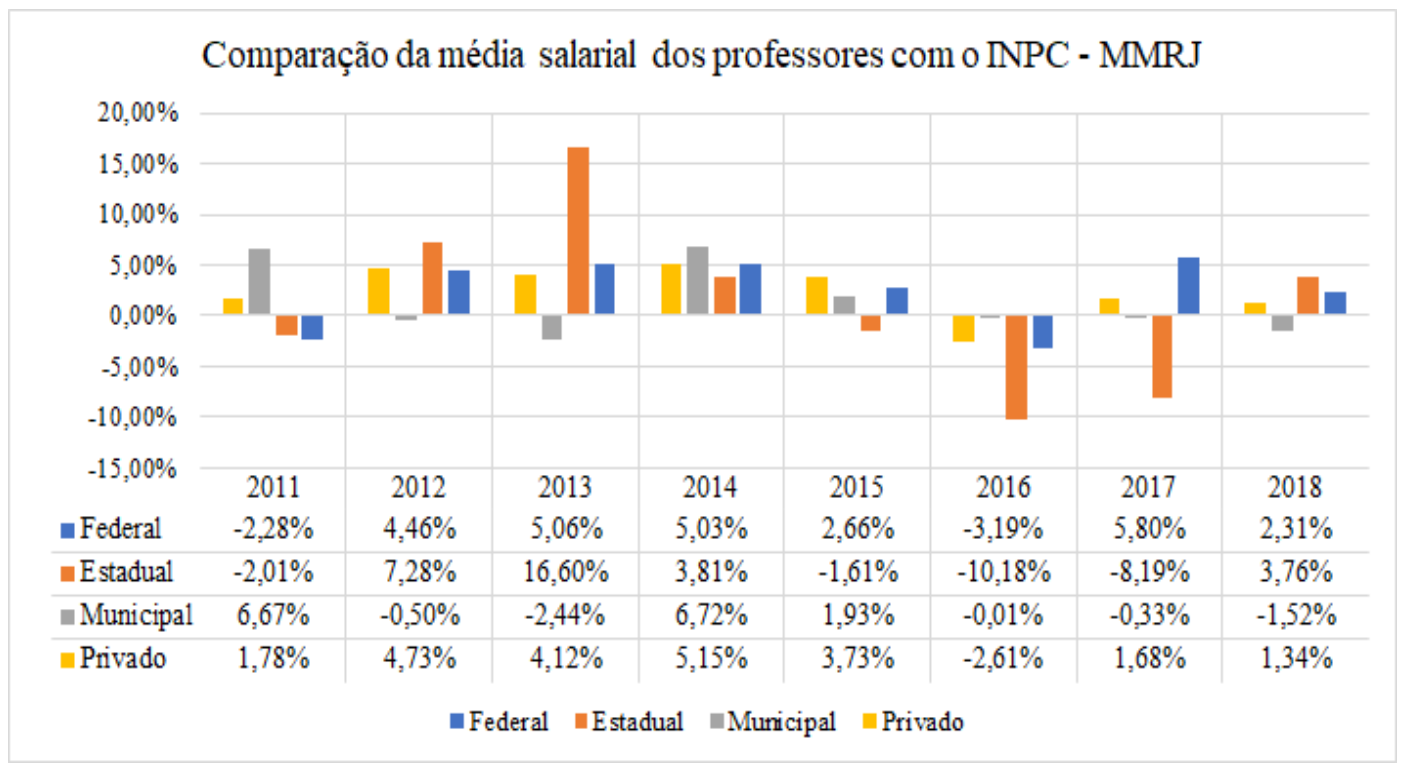

Gráfico 19: Comparação da média salarial de professores com o INPC. Fonte: RAIS- MTE/2018. Elaborado pela autora. 
Podemos observar que os sucessivos cortes na educação, sobretudo após 2015, refletem diretamente o congelamento de salários na rede pública e a redução do poder de compra destes profissionais. Outro ponto é que o discurso de que a privatização melhora os serviços e a qualidade do trabalho se mostram frágeis perante um quadro de remuneração média na rede privada abaixo do valor pago por outras redes e em um patamar inferior ao piso nacional.

Em suma, os dados mostraram às condições de trabalho destes profissionais têm se agravado e que há de fato um acúmulo de escolas, o que corrobora com a ideia de deslocamentos dentro do núcleo urbano. Tais deslocamentos foram mapeados como veremos a seguir, contextualizando com a discussão acerca da mobilidade.

\subsection{Análise espacial da mobilidade docente na MMRJ}

Quando pensamos na mobilidade docente nesta conjuntura vemos que além dos problemas da mobilidade no espaço urbano que atingem todos que vivem nas cidades, há também a questão da imposição de circulação feita pelas condições de trabalho destes indivíduos. Movimentar-se no espaço urbano tornou-se uma exigência criada a partir da metropolização do espaço em função do mercado de trabalho e da precarização da habitação. (BARBOSA, 2016). O acesso a serviços e ao trabalho desigualmente distribuídos pelo território provoca a dependência de deslocamentos.

Além disso, é notório a ampliação das péssimas condições de transporte, acessibilidade e a deterioração do trabalho. Assim, vemos coexistir nas cidades diferentes processos precarizantes que se sobrepõe e se somatizam na vida dos indivíduos, o que nos impõe a necessidade de se pensar políticas públicas integradoras e que tenham como alvo a cidadania e a melhoria das condições de vida da população.

Podemos apontar o tempo como um dos recursos mais desperdiçados nessa dinâmica. A aceleração das cidades impõe o chamado tempo imposto (BARBOSA, 2016), ou seja, o tempo perdido nas viagens que rouba momentos de descanso, lazer, estudo, prazer, entre outros. Isto não é somente determinado pela desigualdade de acesso aos fixos ocasionada por um processo intencionalmente planejado de distinção territorial, mas também pelas imposições do trabalho.

Nesse sentido, quando pensamos nessa mobilidade dos professores não só temos que levar em conta a disposição das escolas pelo território, que embora também 
siga a tendência de centralização, ou seja, em cidades mais populosas e desenvolvidas há maior concentração de unidades escolares, mas também temos que levar em conta os processos que ocasionam esta mobilidade e como esta mobilidade é caracterizada, pois só se pode pensar em soluções práticas compreendendo como o problema se apresenta espacialmente.

Levando em conta o recorte espacial escolhido nesta pesquisa, encontramos nos microdados do Censo Escolar 2018 ${ }^{12}$ um total de 3.291 escolas, sendo 23 federais, 764 estaduais, 990 municipais e 1.514 privadas, como podemos ver no anexo 2. A proporção de professores da rede estadual e municipal (comparados separadamente à rede privada) mostrou-se maior em diversos municípios, sobretudo os periféricos. Nos municípios da Baixada Fluminense predominam professores da rede estadual, já em municípios onde a densidade populacional é menor como Magé, Itaboraí, Japeri, Maricá, Tanguá e Guapimirim predominam professores da rede municipal, também são cidades que possuem menor ligação à cidade do RJ. Já cidades como RJ e Niterói que possuem a maior parte dos docentes vinculados à rede privada, onde o PIB e a renda per capita da população são maiores, confirmando a centralidade dos municípios em relação aos empregos.

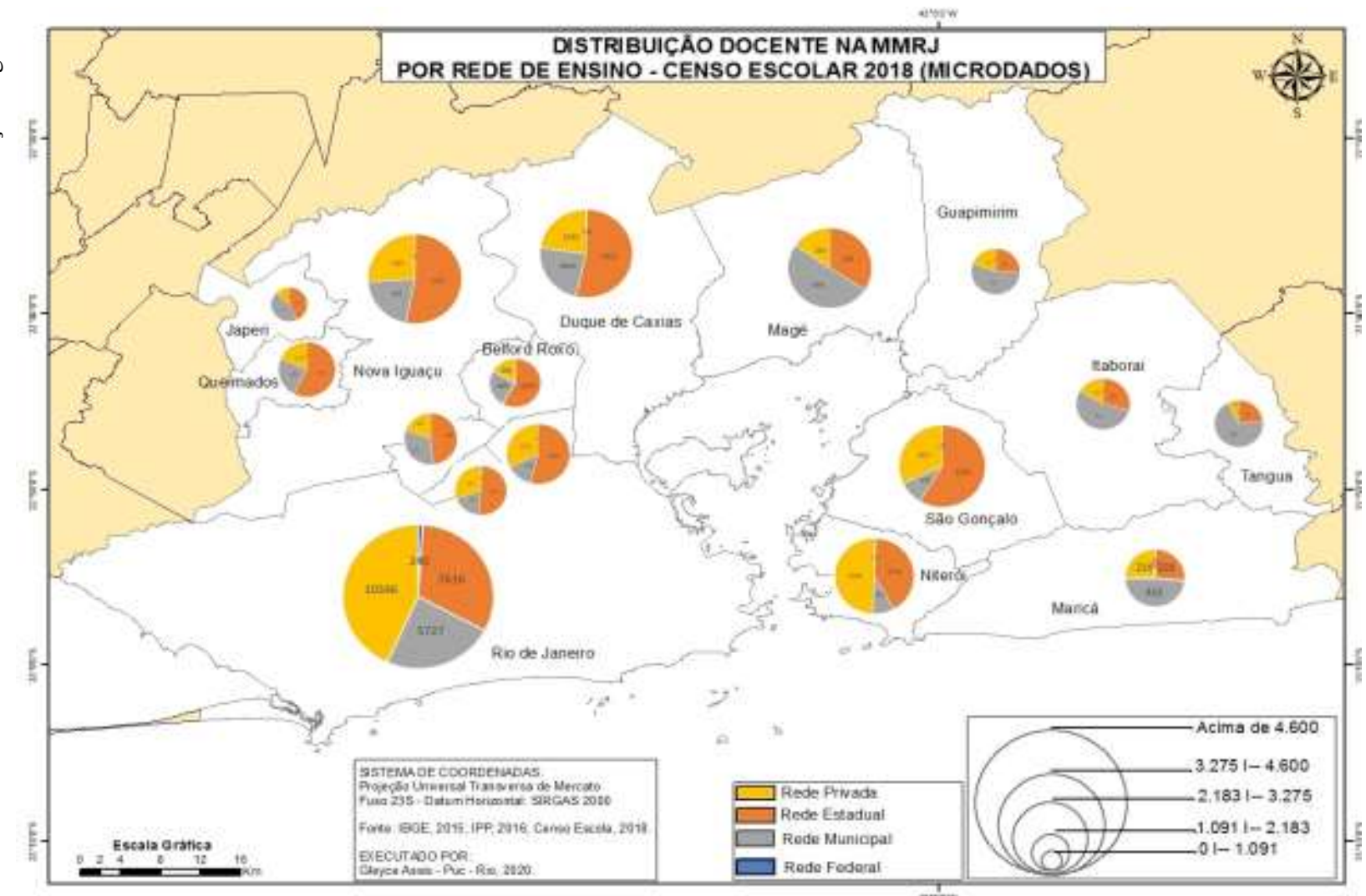

${ }^{12} \mathrm{O}$ Censo Escolar contabiliza um professor por escola, assim o mesmo professor pode aparecer nesta contagem mais de uma vez. 
Mapa 3: Distribuição docente na MMRJ por rede de ensino. Fonte: Censo Escolar, 2018. Elaborado pela autora.

Essa distribuição de professores pelo território, não só revela a hierarquia da região metropolitana fluminense, como também influencia todo o estado. Podemos ver isso através da dimensão mais comum tratada nos estudos de mobilidade: o deslocamento casa-trabalho. Quando olhamos o mapa a seguir do local de moradia dos professores que atuam na MMRJ notamos como faz-se urgente pensar em uma política de mobilidade que leve o trabalho até as pessoas, pois as distâncias percorridas tornam-se cada vez maiores, vide o grande número de professores que moram fora da MMRJ.

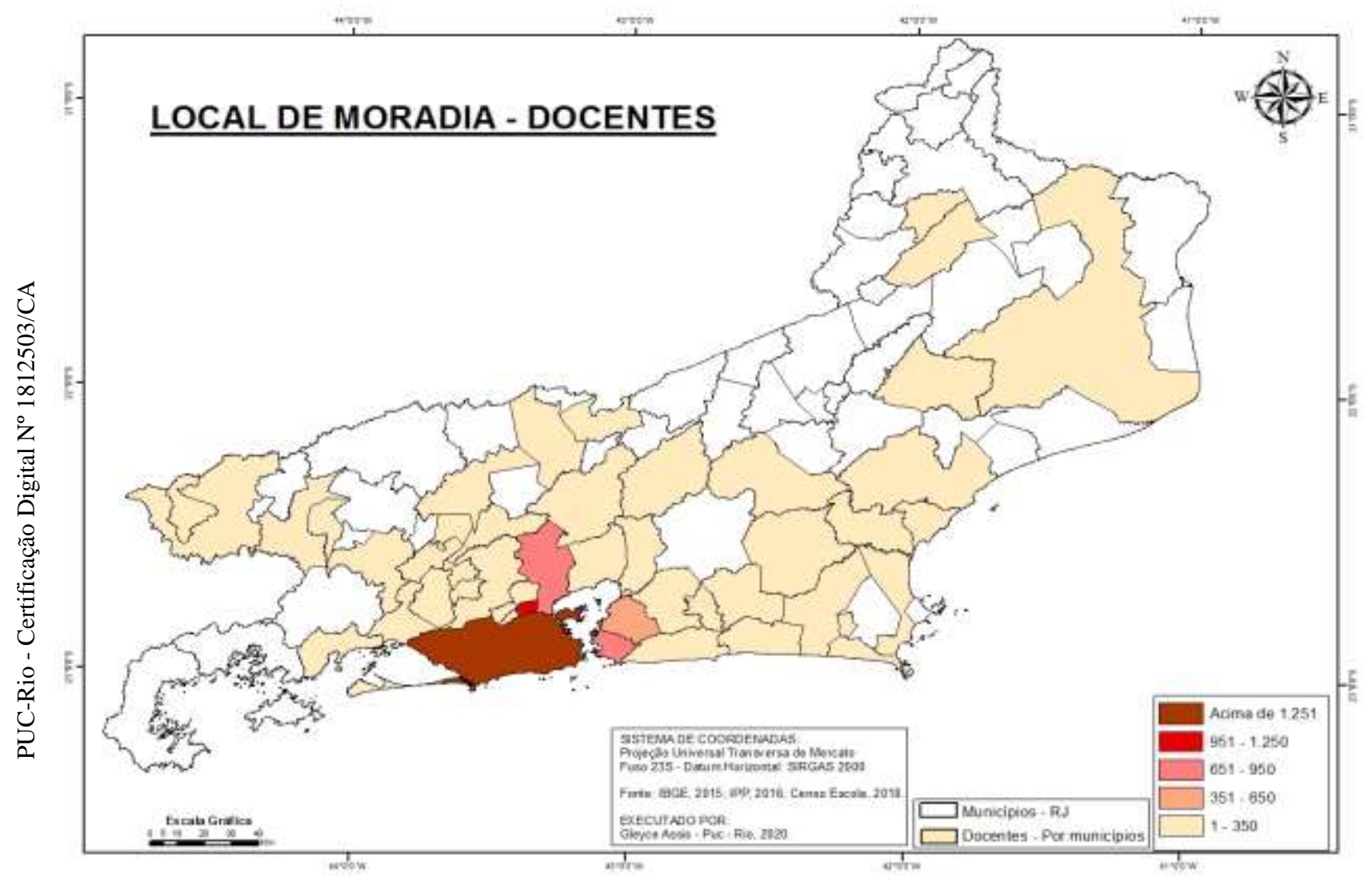

Mapa 4: Local de moradia dos professores que atuam na MMRJ. Fonte: Censo Escolar. Elaborado pela autora.

Nota-se também que os municípios do Rio de Janeiro, Niterói, Duque de Caxias, São João de Meriti e São Gonçalo são os que concentram a maior parte dos professores para alimentar toda a MMRJ. Também se caracterizam pela grande densidade populacional e pelo grande número de universidades se comparados aos demais municípios, o que pode ter ligação com alto índice de professores residindo na região. 
Vale ressaltar que os microdados também revelaram que havia docentes de todo o país, como estes locais coincidiam com a naturalidade do professor descartamos esse mapeamento interestadual por entender que grande parte pode ter sido fruto de erro na hora do preenchimento do município de residência, uma vez que o Censo depende das informações prestadas por funcionários da escola, não é perguntado diretamente ao professor. Todavia, é sabido que a cidade do RJ exerce grande influência nacional, desse modo, não é de se estranhar encontrar professores que residam em outras unidades federativas mais próximas.

Ao levantarmos os deslocamentos casa-trabalho destes indivíduos para a escola principal, ou seja, a escola de maior número de turmas, vemos um emaranhado de fluxos, mostrando a complexidade e interligação presente na MMRJ, sobretudo em direção as redes que possuem a maior remuneração.

DESLOCAMENTO DOCENTE NOS MUNICIPIOS DA MICRORREGIĀO METROPOLITANA DO RJ FLUXO SELECIONADOS (>50) DIREÇĀO CASA - TRABALHO

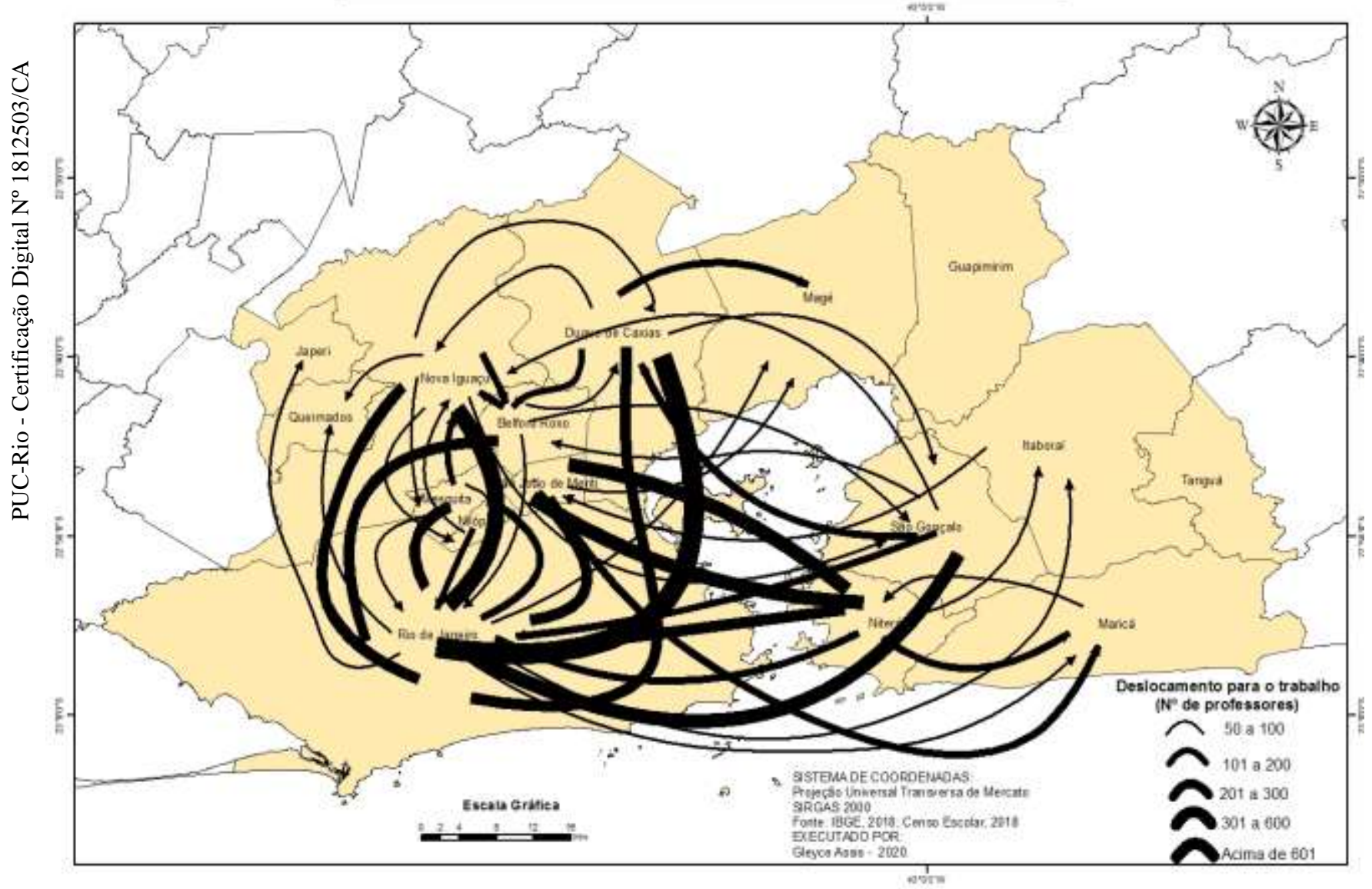

Mapa 5: Deslocamento docente nos municípios da MMRJ - direção casa- trabalho. Fonte: Censo Escolar 2018. Elaborado pela autora.

Neste mapa, apenas os municípios de Guapimirim e Tanguá não apresentaram deslocamento significante intermunicipal dentre os municípios da MMRJ, com isso 
pode-se ter uma grande parte dos docentes destes locais vivendo no município que trabalha, seja porque os municípios possuem uma baixa conexão de transportes com a MMRJ, ou por serem municípios que concentram atividades rurais, ou seja, onde esse ritmo que as cidades impõem é menor. Ou pode-se maior conexão com municípios fora da MMRJ, atraindo docentes que moram nas regiões interioranas ou vice-versa.

Fazendo uma limpeza no mapa e verificando a integração relativa entre os municípios, ou seja, não importando o sentido do fluxo A para B ou B para A, encontramos o seguinte resultado:

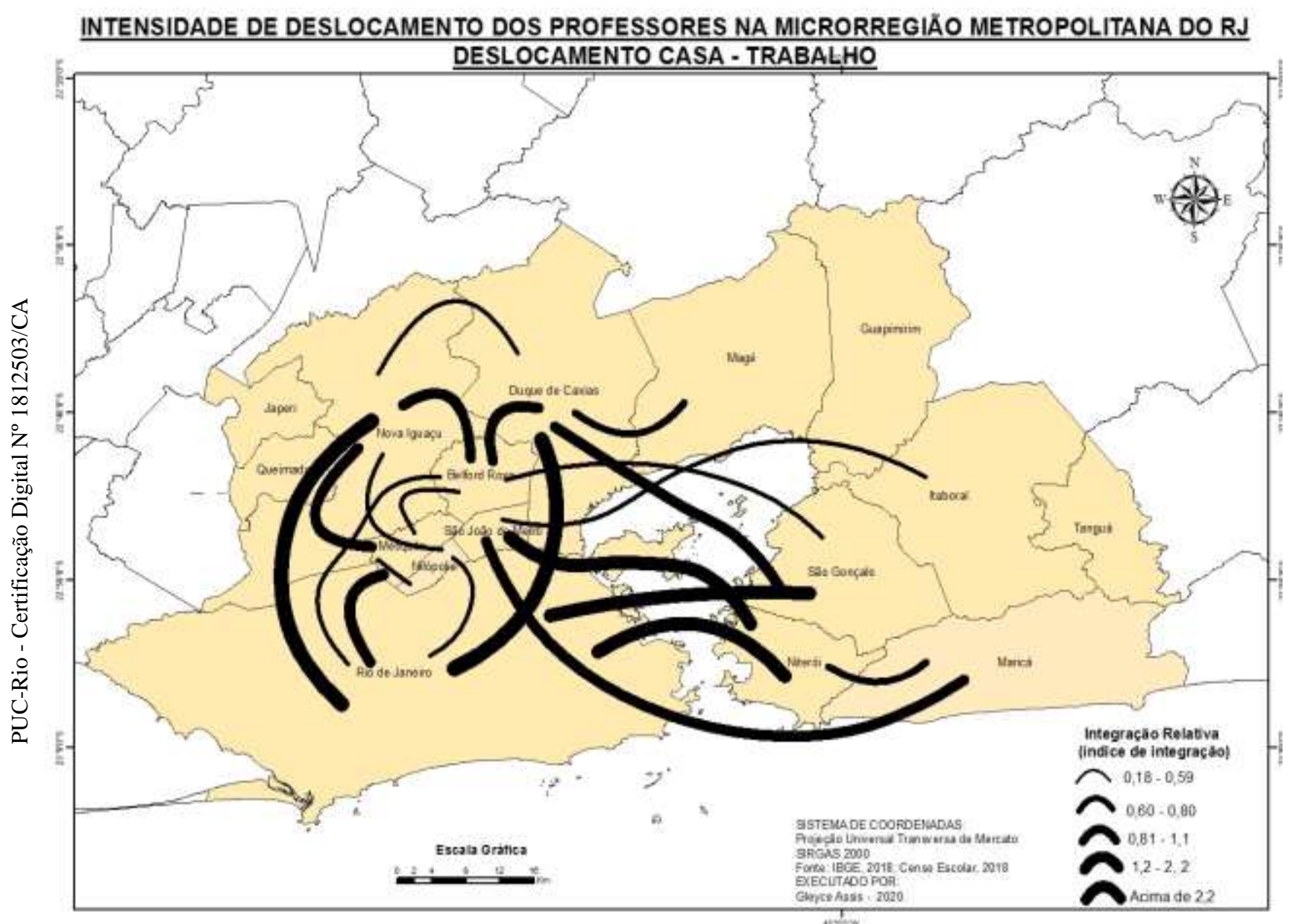

Mapa 6: Intensidade do deslocamento docente na MMRJ - direção casa- trabalho. Fonte: Censo Escolar 2018. Elaborado pela autora.

Olhando para esse mapa conseguimos ver que além daquelas há outras cidades com pouca integração também como Japeri e Queimados. Por outro lado, embora percepção de deslocamento destes professores seja menor do que aqueles que precisam deslocar-se para os demais municípios, não podemos afirmar que a precarização do trabalho docente em relação à mobilidade seja menor, uma vez que confrontando com os dados tratados anteriormente sobre os vínculos empregatícios 
e salários, notamos que há grande número de professores na rede pública sem contratos permanentes e com remuneração abaixo do piso, enquadrando estas pessoas em uma situação de imobilidade, tanto social, por não conseguirem maiores salários e empregos sólidos, quanto espacial, por residirem e trabalharem em locais desconexos da MMRJ, possivelmente configurando-se o retrato de boa parte da população local, que é excluída espacialmente e socialmente do acesso aos bens, serviço, trabalho e outros. Nesse sentido, essas condições estabelecem uma "seleção natural" dos lugares e das pessoas.

A condição urbana desigual das existências e os imperativos da divisão socioespacial do trabalho reúnem-se em formas de localização e modos de distribuição distintiva de bens e serviços, fazendo com que as demandas qualitativas de vida urbana sejam respondidas com as possibilidades de mover-se pela cidade. Para além do trabalho e da habitação, as exigências de educação e cultura - na sua qualidade de direitos sociais, por exemplo - não estão disponíveis para todos os cidadãos, até mesmo quando possuem oferta pública, em função da reduzida mobilidade de determinados grupos sociais. (BARBOSA, 2016, p.49)

Assim a compressão do espaço/tempo imposta pela economia de fluxos coloca aqueles que se deslocam por vários lugares em uma situação de privilégio, por terem acesso ao trabalho, e ao mesmo tempo precarização, pelo esgarçamento da experiência vivida nas metrópoles.

Não se está preconizando que a mobilidade seja restrita à acessibilidade aos bens e serviços urbanos, embora a incorpore em seu processo. A mobilidade é uma prática socioespacial que permite a presença em diferentes lugares como a corporificação de direitos em sujeitos sociais. Estamos colocando em causa não somente as possibilidades técnicas e econômicas dos deslocamentos, mas também o movimento dos atores sociais da cidade e os significados mais abrangentes da mobilidade na mudança de relações sociais. Ou seja, ter acesso aos lugares não significa necessariamente mudar a condição de cliente e consumidor que subordina as pessoas ao Estado e ao mercado. (BARBOSA, 2016, p. 51)

Em 2010, o censo demográfico fornecia informações sobre o deslocamento docente. De um total de 313.643 profissionais da área de educação ${ }^{13}$ entrevistados na pesquisa, 267.452 trabalhavam no município de residência e 43.718 trabalham fora do município de residência e 2.380 trabalhavam em mais de um município, porém os dados de 2018 do Censo Escolar mostraram que este número era muito superior,

\footnotetext{
${ }^{13}$ O Censo 2010 classifica por área de trabalho, não distingue professores de outros profissionais da educação.
} 
isso se deve à coleta amostral feita pelo Censo 2010 que não representava todos os docentes da região. Além disso, a pesquisa também mostrou que dentre os trabalhadores com nível superior (16,8\% dos trabalhadores da educação) que se deduz englobar em maior número os professores, 83,5\% trabalhavam no município de residência, $15 \%$ em outro município e 1,3\% em mais de um município. Dentre os profissionais que atuam na educação e que possuem superior completo, $71,9 \%$ eram mulheres e $28 \%$ homens.

O mapa abaixo realizado com dados do Censo Escolar 2018 mostra como essa acessibilidade funciona para uns e não para outros. A disposição de escolas no território fluminense obedece a uma centralidade que obriga professores de municípios periféricos a deslocarem-se para fora do município de residência, similar ao que acontece com os demais trabalhadores, mostrando que embora a categoria tenha suas especificidades no que tange o desenho espacial, ela também se encontra imersa no arranjo provocado pela metropolização.
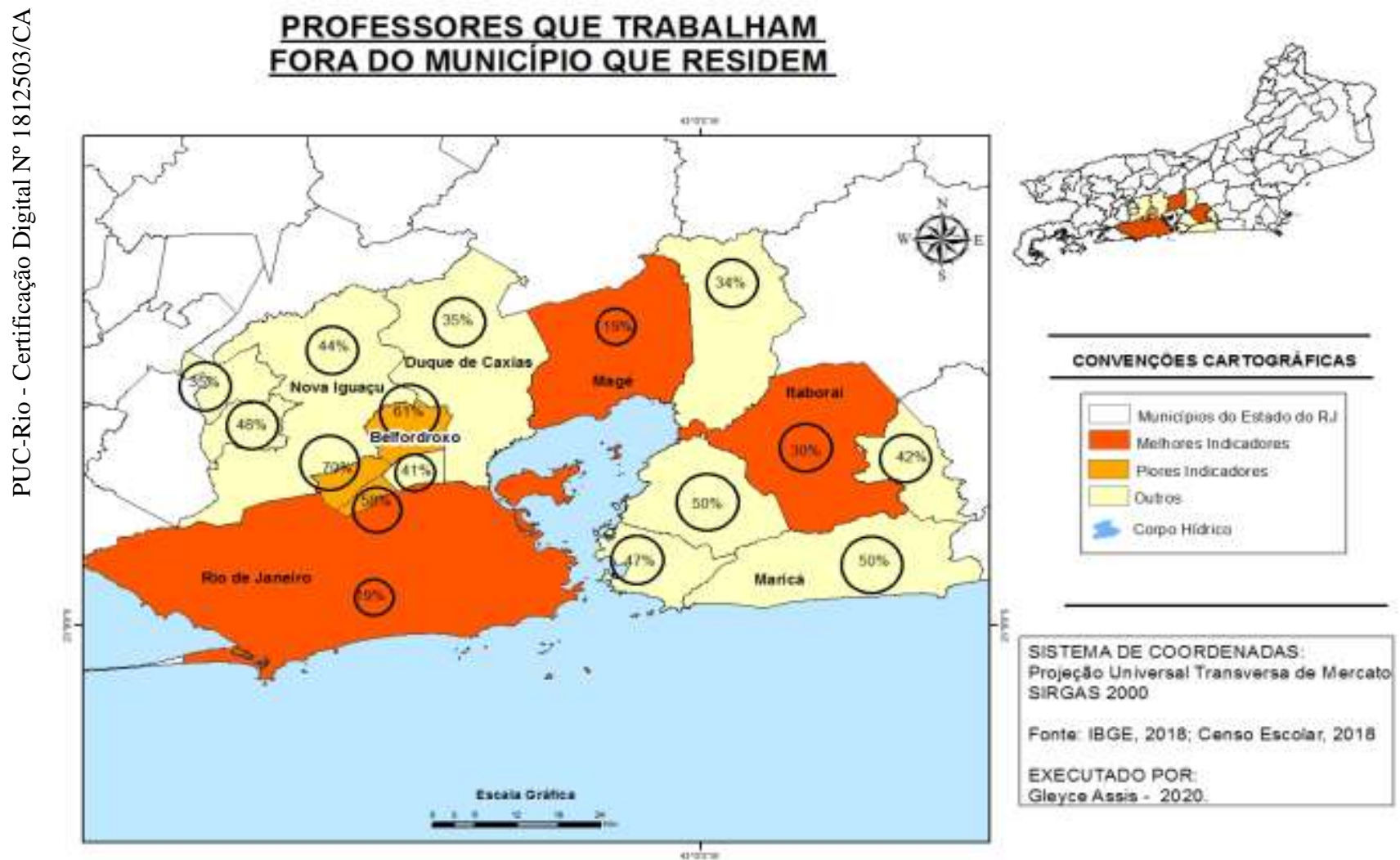

Mapa 7: Docentes que trabalham fora do município onde moram. Fonte: Censo Escolar 2018 Elaborado pela autora.

Outro ponto relevante que chamou atenção é que apesar dos professores que residem nesses municípios periféricos necessitarem se deslocar para escolas em outros locais, é a metrópole do Rio de Janeiro que fornece maior volume de 
docentes para os demais municípios da MMRJ, representado por esses 19\% que não só trabalham no próprio município, mas também nos demais.

Isto reforça a ideia de centralização no que tange ao local de moradia, local de formação de mão de obra qualificada e descentralização do trabalho, pois além da cidade da RJ absorver a maior parte da mão de obra docente do estado e da MMRJ, ela também funciona como fornecedora para as demais, pois a periferia é redefinida na metropolização, tornam-se um polo de atração também. Barbosa (2016) conta que o modelo de periferia desprovida de recursos e atratividade é ultrapassado. Nas regiões metropolitanas há sim o papel hierárquico e de comando, ou seja, de centralidade, mas isso é reproduzido no espaço, construindo novas centralidades, seja pelo adensamento populacional, pela quantidade de cursos e faculdades de formação de professores que ali existem, pelos salários mais atrativos nesses municípios, entre outros.

Podemos pensar a partir disso que a percepção de mobilidade daqueles que percorrem o sentido centro-periferia e daqueles que percorrem o contrário a partir do local de moradia é totalmente diferente. Deslocar-se no contrafluxo dos demais trabalhadores em horário de rush para chegar a uma escola periférica pode ser um trajeto que demanda menor tempo do que quem faz o sentido contrário.

\section{MOVIMENTO PENDULAR INTRAMETROPOLITANO} DE PROFESSORES QUE RESIDEM NO RIO DE JANEIRO

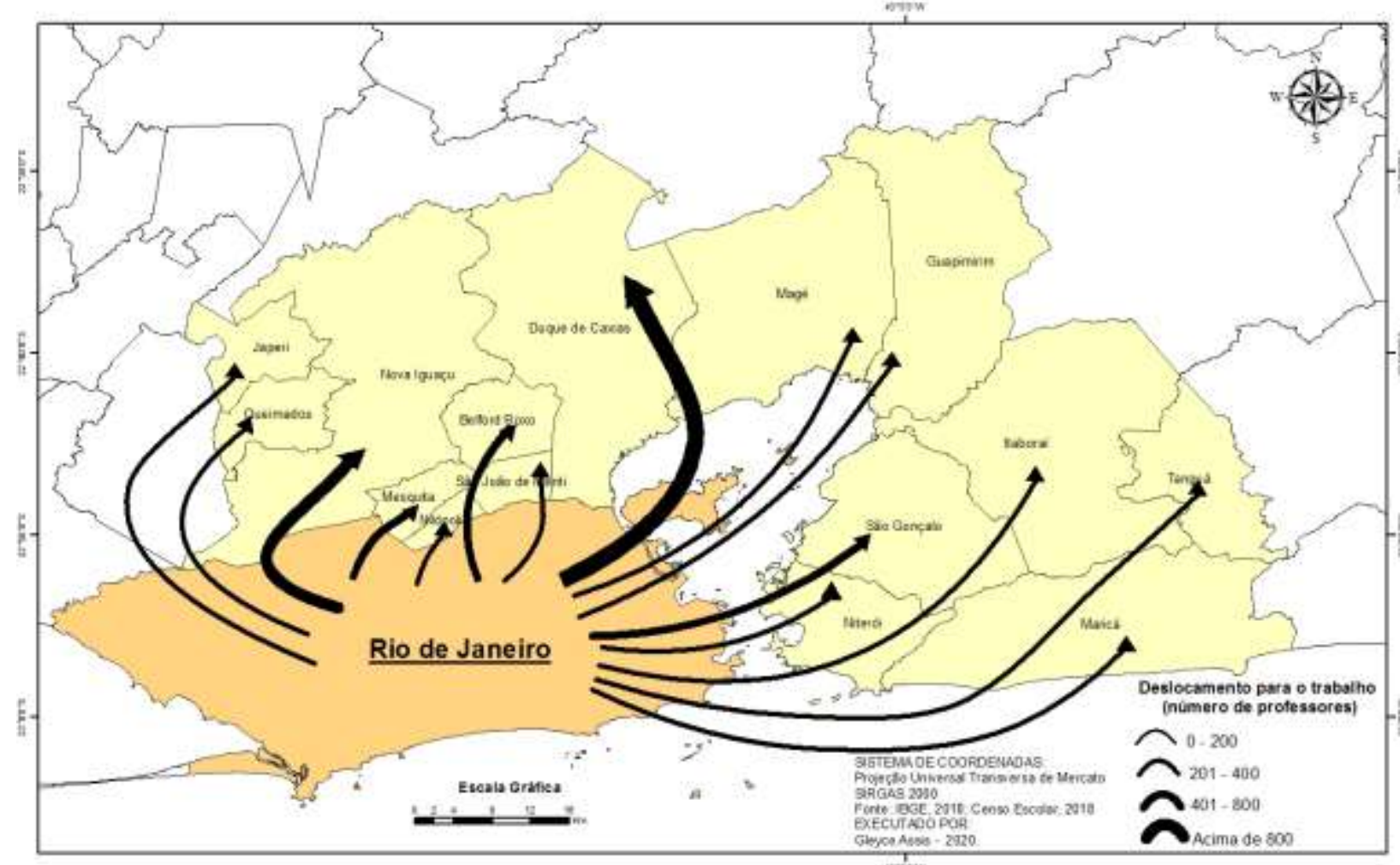


Mapa 8: movimento pendular intrametropolitano de professores que residem no RJ e trabalham na MMRJ. Fonte: Censo Escolar 2018. Elaborado pela autora.

Note que as principais ligações que a cidade estabelece são com os municípios de Duque de Caxias e Nova Iguaçu. O primeiro possivelmente pela remuneração municipal ser mais atrativa do que outros municípios, o que mostra que a razão econômica pode estar acima da questão de distância e tempo para chegar ao trabalho. E o segundo, pela grande quantidade de escolas. Embora Niterói tenha a maior média de remuneração, é preciso pontuar que assim como o RJ, é um local centralizador no que se refere à formação de docentes, por isso não exerce tamanha atratividade de docentes do RJ, como as cidades citadas na Baixada Fluminense.

\section{Remuneração média nominal na MMRJ - Docentes da Educação Básica - RAIS 2018}

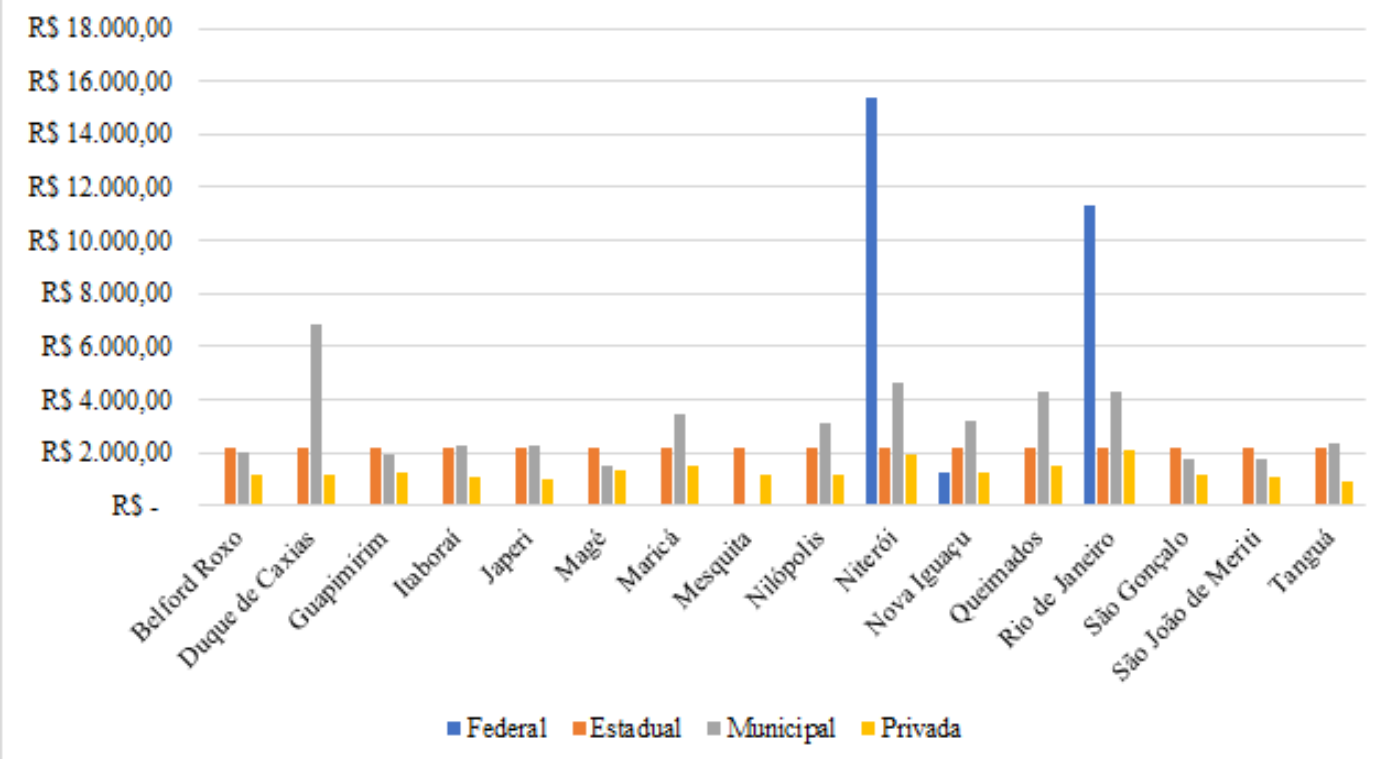

Gráfico 20: Remuneração média nominal na RMRJ por município e esfera administrativa. Fonte: RAIS-MTE/2018. Elaborado pela autora.

Assim, nos parece claro que os diversos modos de deslocamento são promovidos pelas questões econômicas, técnicas e culturais das metrópoles, o que gera múltiplas experiências urbanas com diferentes velocidades. Quando falamos dos professores é necessário pensar para além dos deslocamentos pendulares casa-trabalho, mas também interescolas que ocorrem em meio a todos os demais problemas da cidade. Nesse sentido, consideramos relevante buscar nos microdados do Censo Escolar 2018 informações que pudessem retratar melhor a realidade destes profissionais. Desse modo, os resultados mostraram que dos docentes que atuavam nos anos finais e ensino médio na MMRJ cerca de 52\% trabalhava em apenas uma única escola, 
$32,8 \%$ trabalhavam em duas escolas, $10,4 \%$ em três, $4,3 \%$ em quatro ou mais escolas. O número máximo de escolas por professor encontrado na pesquisa foi de 10 unidades escolares, porém representou um número muito pequeno de professores, como podemos ver na tabela abaixo.

\begin{tabular}{|c|c|c|c|c|c|c|c|c|c|c|}
\hline \multirow[b]{2}{*}{$\begin{array}{c}\text { Professores que } \\
\text { atuam em }\end{array}$} & \multirow[b]{2}{*}{$\begin{array}{c}\text { Número } \\
\text { Total }\end{array}$} & \multicolumn{2}{|c|}{ Sexo \% } & \multicolumn{7}{|c|}{ Faixa etária \% } \\
\hline & & $\mathrm{F}$ & $\mathrm{M}$ & Até 20 & $21-30$ & $31-40$ & $41-50$ & $51-60$ & $\begin{array}{l}\text { Acima } \\
\text { de } 60\end{array}$ & Omisso \\
\hline uma escola & 32.245 & 58,6 & 43,2 & 100,0 & 57,6 & 47,5 & 49,0 & 56,2 & 70,4 & 0,0 \\
\hline duas escolas & 20.276 & 30,6 & 36,2 & 0,0 & 28,5 & 35,1 & 35,2 & 31,3 & 23,4 & 0,0 \\
\hline três escolas & 6.461 & 8,2 & 13,8 & 0,0 & 9,4 & 12,0 & 11,3 & 9,1 & 5,6 & 0,0 \\
\hline quatro escolas & 1.881 & 1,9 & 4,6 & 0,0 & 3,0 & 3,7 & 3,2 & 2,5 & 0,3 & 100,0 \\
\hline cinco escolas & 586 & 0,5 & 1,6 & 0,0 & 0,9 & 1,2 & 1,0 & 0,7 & 0,3 & 0,0 \\
\hline seis escolas & 154 & 0,1 & 0,4 & 0,0 & 0,3 & 0,3 & 0,2 & 0,2 & 0,1 & 0,0 \\
\hline sete escolas & 36 & 0,0 & 0,1 & 0,0 & 0,1 & 0,1 & 0,0 & 0,0 & 0,0 & 0,0 \\
\hline oito escolas & 15 & 0,0 & 0,0 & 0,0 & 0,0 & 0,0 & 0,0 & 0,0 & 0,0 & 0,0 \\
\hline nove escolas & 7, & 0,0 & 0,0 & 0,0 & 0,1 & 0,0 & 0,0 & 0,0 & 0,0 & 0,0 \\
\hline dez escolas & 3, & 0,0 & 0,0 & 0,0 & 0,0 & 0,0 & 0,0 & 0,0 & 0,0 & 0,0 \\
\hline Total & 61.664 & 100,0 & 100,0 & 100,0 & 100,0 & 100,0 & 100,0 & 100,0 & 100,0 & 100,0 \\
\hline
\end{tabular}

Tabela 4: distribuição de docentes pelo no de escolas que atua, pelo sexo e faixa etária. Fonte: Censo 2018. Elaborado pela autora.

Vale ressaltar que o deslocamento não é igual para os indivíduos, notou-se que embora a maior parte dos docentes seja do sexo feminino, quando se fala de acúmulo de escolas, encontramos um maior número de unidades vinculadas aos docentes do sexo masculino. O mesmo ocorre com relação à faixa etária, entre 31 a 40 anos e entre 41 a 50 anos a porcentagem dos que atuavam em até três escolas, por exemplo, representava em torno de $11 \%$ a $12 \%$ do total dessas faixas etárias, já entre os professores de 51 a 60 anos representava 9\%, e acima de 60 anos, apenas $5 \%$, o que mostra que quanto mais avançada a idade, menor é a quantidade de docentes trabalhando em muitas escolas, porém em todas as faixas etárias acima de 21 anos foi verificado um grande número de docentes atuando em até seis escolas.

O cansaço pode estar relacionado a isso.

\begin{tabular}{|c|c|c|c|c|c|c|c|c|c|c|c|}
\hline \multirow{2}{*}{$\begin{array}{l}\text { Professores } \\
\text { que atuam em }\end{array}$} & \multicolumn{11}{|c|}{ Disciplina \% } \\
\hline & Artes & $\begin{array}{c}\mathrm{Bio} / \\
\text { ciências }\end{array}$ & $\begin{array}{c}\text { Ed. } \\
\text { Física }\end{array}$ & Física & Geografia & História & Inglês & Matemática & Português & Química & Omisso \\
\hline uma escola & 51,4 & 54,1 & 64,4 & 35,0 & 52,0 & 56,7 & 53,8 & 52,1 & 63,1 & 40,6 & 0,0 \\
\hline duas escolas & 31,9 & 31,0 & 26,5 & 36,1 & 30,6 & 28,1 & 33,0 & 32,8 & 28,2 & 35,4 & 100,0 \\
\hline três escolas & 11,2 & 10,4 & 6,8 & 18,3 & 12,0 & 10,8 & 9,7 & 11,0 & 6,8 & 16,1 & 0,0 \\
\hline quatro escolas & 3,6 & 3,2 & 1,7 & 6,6 & 3,8 & 3,3 & 2,4 & 3,1 & 1,4 & 5,4 & 0,0 \\
\hline cinco escolas & 1,3 & 0,9 & 0,5 & 2,9 & 1,2 & 0,9 & 0,7 & 0,9 & 0,4 & 1,8 & 0,0 \\
\hline seis escolas & 0,4 & 0,2 & 0,1 & 0,6 & 0,3 & 0,3 & 0,2 & 0,1 & 0,1 & 0,5 & 0,0 \\
\hline sete escolas & 0,1 & 0,0 & 0,0 & 0,3 & 0,1 & 0,0 & 0,1 & 0,0 & 0,0 & 0,1 & 0,0 \\
\hline oito escolas & 0,1 & 0,0 & 0,0 & 0,2 & 0,0 & 0,0 & 0,0 & 0,0 & 0,0 & 0,0 & 0,0 \\
\hline nove escolas & 0,0 & 0,0 & 0,0 & 0,0 & 0,0 & 0,0 & 0,0 & 0,0 & 0,0 & 0,0 & 0,0 \\
\hline dez escolas & 0,0 & 0,0 & 0,0 & 0,0 & 0,0 & 0,0 & 0,0 & 0,0 & 0,0 & 0,0 & 0,0 \\
\hline
\end{tabular}


Tabela 5: distribuição de docentes pelo no de escolas que atua e por disciplina que leciona. Fonte: Censo escolar 2018. Elaborado pela autora.

Em relação as disciplinas, também se verificou algumas discrepâncias. Embora a maior parte dos docentes seja de português e matemática - 14,3 e 13,9\% do total, respectivamente, os de artes, física e química foram os apareceram atuando em mais escolas, indicando que a fragmentação de tempos de aulas corrobora para a maior circulação, uma vez que tanto a rede pública quanto privada contrata os professores em regimes diferenciados de carga horária conforme a disciplina, segmento e turno que lecionam. Sem contar que são disciplinas que não são ofertadas para todas as séries, assim torna-se difícil completar todos os tempos de aula em uma só escola. Isso contribui para o aumento das desigualdades entre os docentes e torna-se um desafio para a gestão educacional, pois a própria matriz curricular nacional, ou seja, tanto a BNCC quanto o PCN colocam pesos diferenciados nos conteúdos e carga horária entre as disciplinas. Além disso, a demanda por profissões de exatas é maior do que as demais disciplinas, devido o número reduzido de professores destas áreas no mercado, o que favorece uma maior diluição de tempos de aula em diversas unidades escolares.

\begin{tabular}{|c|c|c|c|c|c|}
\hline \multirow{2}{*}{$\begin{array}{c}\text { Professores que atuam } \\
\text { em }\end{array}$} & \multicolumn{5}{|c|}{ Escolaridade \% } \\
\cline { 2 - 6 } & Graduação & $\begin{array}{c}\text { Pós- } \\
\text { graduação }\end{array}$ & Mestrado & Doutorado & Omisso \\
\hline uma escola & 49,6 & 52,0 & 56,4 & 70,9 & 75,5 \\
\hline duas escolas & 34,5 & 33,3 & 29,9 & 20,9 & 22,7 \\
\hline três escolas & 11,2 & 10,3 & 9,7 & 5,9 & 1,8 \\
\hline quatro escolas & 3,3 & 3,2 & 2,9 & 1,4 & 0,0 \\
\hline cinco escolas & 1,0 & 0,9 & 0,9 & 0,5 & 0,0 \\
\hline seis escolas & 0,3 & 0,2 & 0,2 & 0,2 & 0,0 \\
\hline sete escolas & 0,1 & 0,1 & 0,0 & 0,1 & 0,0 \\
\hline oito escolas & 0,0 & 0,0 & 0,0 & 0,0 & 0,0 \\
\hline nove escolas & 0,0 & 0,0 & 0,0 & 0,0 & 0,0 \\
\hline dez escolas & 0,0 & 0,0 & 0,0 & 0,0 & 0,0 \\
\hline Total & 100,0 & 100,0 & 100,0 & 100,0 & 100,0 \\
\hline
\end{tabular}

Tabela 6: distribuição de docentes pelo no de escolas que atuam e o nível de formação. Fonte: censo escolar (2018). elaborado pela autora.

O mesmo ocorre em relação à escolaridade, por exemplo, aqueles que trabalham em até três escolas e possuem somente a graduação representam 11,2\% dos docentes desse nível de formação, na medida em que a escolaridade aumenta a proporção de professores associados à muitas escolas diminui, aqueles que possuem doutorado e trabalham em até três escolas representam 5,9\% do total dos professores doutores, como podemos observar na tabela a seguir. Isso nos ajuda a 
pensar que a busca pela maior formação se tornar uma forma de aumentar a remuneração e diminuir a necessidade de deslocar-se por muitas escolas, pois cada rede possui um plano próprio de carreira com incorporação salarial conforme o nível de escolaridade.

Em relação ao tipo de contratação, vimos que a precarização salarial atinge docentes de todas as redes, especialmente estadual e privada, onde os salários mostraram-se abaixo do piso e sem reajustes ao longo dos últimos cinco anos (2015-2019). Na comparação entre professores que possuem contratos temporários e aqueles que são concursados, nota-se que a proporção de docentes atuando em até três escolas, por exemplo, é de $11 \%$ no primeiro grupo e de $8 \%$ no segundo. Porém isso não se verificou entre os terceirizados, representados por $4 \%$ dos docentes do grupo, concentrando a maior parte dos professores em apenas uma escola, o que também coloca esses professores em situação de imobilidade espacial.

\begin{tabular}{|c|c|c|c|c|c|}
\hline & \multicolumn{5}{|c|}{ Tipo de contratação \% } \\
\cline { 2 - 6 } Professores que atuam em & Concursado & Temporário & Terceirizado & CLT & Omisso \\
\hline uma escola & 53,5 & 43,2 & 81,8 & 28,6 & 50,7 \\
\hline duas escolas & 34,5 & 39,2 & 9,1 & 57,1 & 29,4 \\
\hline três escolas & 8,9 & 11,8 & 4,5 & 14,3 & 13,4 \\
\hline quatro escolas & 2,3 & 4,4 & 4,5 & 0,0 & 4,4 \\
\hline cinco escolas & 0,6 & 1,1 & 0,0 & 0,0 & 1,5 \\
\hline seis escolas & 0,2 & 0,2 & 0,0 & 0,0 & 0,4 \\
\hline sete escolas & 0,0 & 0,1 & 0,0 & 0,0 & 0,1 \\
\hline oito escolas & 0,0 & 0,1 & 0,0 & 0,0 & 0,0 \\
\hline nove escolas & 0,0 & 0,0 & 0,0 & 0,0 & 0,0 \\
\hline dez escolas & 0,0 & 0,0 & 0,0 & 0,0 & 0,0 \\
\hline Total & 100,0 & 100,0 & 100,0 & 100,0 & 100,0 \\
\hline
\end{tabular}

Tabela 7: distribuição docente pelo tipo de contratação. Fonte: Censo Escolar 2018. Elaborado pelo autor.

Já aqueles que possuem CLT na rede pública estão em situação percentual semelhante aos temporários no que se refere a proporção de docentes que atua em três escolas. Desse modo, podemos apontar duas tendências no que tange a mobilidade interescolas: a hipermobilidade daqueles que detém renda e meios para percorrer diversas localidades e a imobilidade daqueles que estão em situação de trabalho parcialmente ou totalmente instável. Já os casos omissos referem-se aos docentes que atuam na rede privada, pois como falado anteriormente, estes não são levados em consideração neste item. 
Desse modo, a intensidade da mobilidade cotidiana possui relação com diversos fatores como a acessibilidade ao mercado de trabalho, a hierarquia espacial (centro e periferia), os meios de transportes, a localização das atividades produtivas no território e outros. Nesse sentido, a distância e o tempo gasto no deslocamento exercem o papel de indicadores importantes para se compreender a reprodução das desigualdades socioespaciais.

Vale ressaltar que os docentes concursados embora estejam em uma situação assegurada perante os demais, também encontram a precarização no interior das próprias redes públicas, pois muitos trabalham em diversas escolas para completar a carga horária daquela rede, embora isso não seja uma realidade frequente dos docentes federais, pois nesta rede a alocação geralmente ocorre em apenas uma unidade escolar e em geral os regimes são de 40 horas semanais ou dedicação exclusiva.

Essas desigualdades no que se refere ao sexo, escolaridade, vínculo empregatício e outros, mostram-se no espaço e este não é sentido da mesma forma por todos. Nele há relações de poder e dominação que agravam os problemas sociais. É no espaço que se defrontam aqueles que são vedados o direito de ir e vir, outros em que este direito lhes são permitidos e aqueles em que o direito se torna uma obrigação, por vezes uma pessoa pode experimentar as três condições, dependendo de onde queira ir. Portanto, é no espaço que processos de mobilidade e imobilidade da população se confrontam e coexistem.

Para Oliveira (2009), as formas de dominação presentes na relação capital-trabalho, a convivência de modelos de acumulação distintos, a inserção das atividades produtivas no espaço, e o papel da globalização são processos que afetam a mobilidade espacial da força de trabalho. Desse modo, neste novo padrão de acumulação, a produção flexível estaria atrelada às práticas empresariais de subcontratação, terceirização, cortes de trabalhadores e produção sob encomenda. Portanto, afirma ele "esse processo de transição histórica para uma sociedade informacional e uma economia global seria caracterizado pela deterioração generalizada das condições de trabalho e de vida para os trabalhadores" (Ibidem, p. 23). Assim, a mobilidade da força de trabalho relaciona-se a uma vulnerabilidade da mão de obra sob condições de flexibilidade que não só afeta trabalhadores não qualificados, mas também os qualificados, devido ao encurtamento do período de vida profissional (CASTELLS, 1999 apud OLIVEIRA, 2009). 
Toda essa transformação, que mantém a essência do domínio do capital, tem impacto sobre a força de trabalho, em particular pela flexibilização e precarização. Esses fatores em conjunto gerariam estratégias diferentes quando os indivíduos buscam garantir a sua reprodução, incluindo, nesse escopo, as estratégias de mobilidade espacial. (OLIVEIRA, 2009, p.22)

Nesse sentido, o autor afirma que as transformações no trabalho impactam a força de trabalho e associadas à mobilidade espacial causam o desdobramento dos trabalhadores. Vemos isso com a categoria docente se deslocando por diversas escolas e em muitos casos não se trata de maximizar ganhos, mas sim conseguir algum meio de sobrevivência.

O mapa a seguir mostra o deslocamento interescolas intrametropolitano. Escolhemos como melhores indicadores os municípios que apresentavam maior porcentagem de docentes trabalhando em até duas escolas do mesmo município, por considerar as menores distâncias um parâmetro de uma melhor mobilidade. Porém, como dito anteriormente, sabe-se que as cidades possuem diferentes níveis de acessibilidade e mobilidade, circular na cidade do Rio de Janeiro, por exemplo, entre duas escolas em bairros vizinhos pode ser muito demorado e dispendioso a depender do horário e tipo de transporte que se escolhe.

\section{PROFESSORES QUE ATUAM EM ATÉ DUAS ESCOLAS DO MESMO MUNICIPIO}
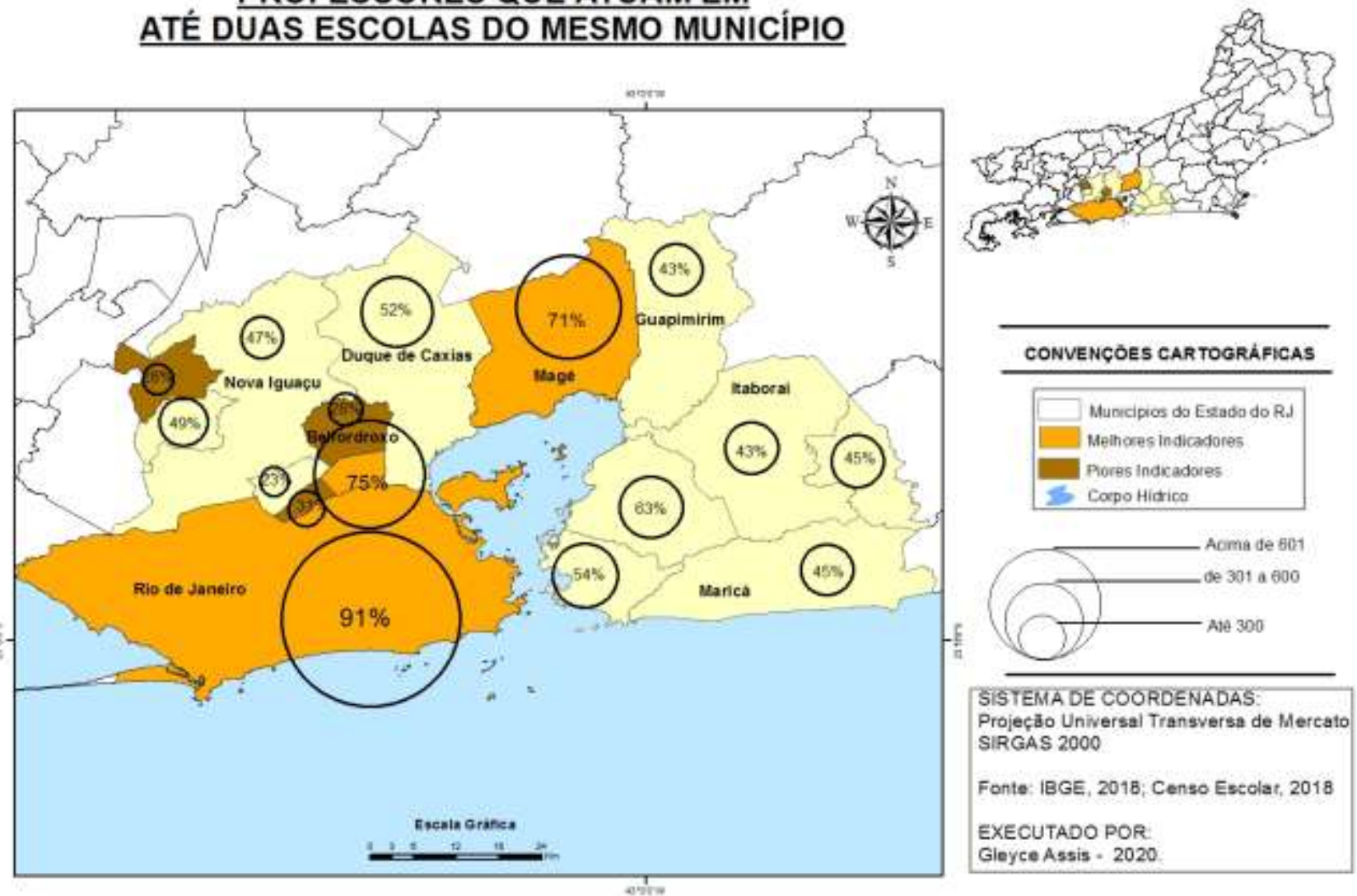
Mapa 9: percentual de professores que atuam em até duas escolas do mesmo município. Fonte: Censo Escolar 2018. Elaborado pela autora.

É importante ressaltar que grande parte desse deslocamento dentro do próprio município ocorre em escolas da mesma rede de ensino. Félix (2019) afirma que a permanência da cidade não significa uma redução na circulação da força de trabalho. Assim, o problema se relaciona diretamente a uma reprodução de um mercado de trabalho altamente circulatório, como aponta o autor. Nesse sentido, os processos que permitem esse tipo de fenômeno se calçam em parâmetros legais de flexibilização e com isso geram uma completa ausência de um planejamento territorial de distribuição dos docentes. A fragmentação da carga horária em diversas unidades não contribui para melhor gestão, funcionamento escolar ou para o trabalho do professor. Pelo contrário, contribui para o desgaste, para mascarar o trabalho parcial e exime as redes de contratação de novos professores.

Uma política de melhor distribuição dos professores pelo território poderia ser mais fácil no âmbito estadual, uma vez que nessa escala seria possível aproximar trabalho e moradia, mesmo que ainda permanecesse o deslocamento interescolas, estas seriam mais próximas, poderia ser uma forma de mitigar tal deslocamento.

\begin{tabular}{|l|r|r|r|r|}
\hline \multirow{2}{*}{ Professores que atuam em duas escolas da mesma rede no mesmo } \\
município \% \\
\hline \multirow{2}{*}{ Município } & \multicolumn{4}{|c|}{ Dependência Administrativa } \\
\cline { 2 - 5 } & Municipais & Estaduais & Federais & Privadas \\
\hline Belford Roxo & 10,71 & 49,70 & 0,00 & 11,01 \\
\hline Duque de Caxias & 17,90 & 44,89 & 0,00 & 20,90 \\
\hline Guapimirim & 43,48 & 21,74 & 0,00 & 2,17 \\
\hline Itaboraí & 31,47 & 20,98 & 0,00 & 10,14 \\
\hline Japeri & 9,26 & 24,07 & 0,00 & 14,81 \\
\hline Magé & 32,82 & 24,29 & 0,00 & 8,79 \\
\hline Maricá & 26,63 & 18,34 & 0,00 & 20,12 \\
\hline Mesquita & 27,14 & 31,43 & 0,00 & 22,86 \\
\hline Nilópolis & 32,90 & 30,97 & 0,00 & 24,52 \\
\hline Niterói & 3,41 & 31,27 & 0,00 & 35,29 \\
\hline Nova Iguaçu & 13,73 & 41,18 & 0,00 & 22,43 \\
\hline Queimados & 16,38 & 33,62 & 0,00 & 18,97 \\
\hline Rio de Janeiro & 9,88 & 18,23 & 0,23 & 33,54 \\
\hline São Gonçalo & 5,84 & 50,66 & 0,00 & 23,34 \\
\hline São João de Meriti & 4,85 & 46,09 & 0,00 & 27,12 \\
\hline Tanguá & 3,45 & 55,17 & 0,00 & 3,45 \\
\hline
\end{tabular}

Tabela 8: percentual de professores que atuam em duas escolas da mesma rede de ensino no mesmo município. Fonte: Censo Escolar 2018. Elaborado pela autora.

A tabela 8 mostra o número de professores que atua em duas escolas no mesmo município por dependência administrativa. Podemos observar que a distribuição de 
professores ocorre dentro da própria rede de ensino. Este número certamente é maior visto que não foi levantado o número total de escolas que o docente atua por rede de ensino e para além de apenas um município como é o caso dos professores do estado do RJ.

Vemos que em todos os municípios, os professores da rede estadual são se encontram mais fragmentados pelo território. Associado as questões de congelamento de salários e demais problemas que a rede vive, tem-se um cenário de precarização que abrange boa parte desses docentes.

Vale salientar que a alocação dos professores por unidade escolar não ocorre de forma aleatória. A subdivisão da rede estadual se dá pelas Coordenadorias Gerais de Ensino, em geral os professores são distribuídos em escolas de uma mesma coordenadoria, porém o tamanho destas é variável. Algumas comportam apenas alguns bairros da cidade do Rio, outras municípios de grande extensão territorial. A prefeitura do Rio segue a mesma tendência, distribuindo e descentralizando a administração das escolas pelas Coordenadorias Regionais de Educação, contudo o tamanho dos bairros e a acessibilidade também é diferenciado. Outros municípios de maior extensão organizam essa distribuição por distrito, como por exemplo Duque de Caxias. Isso ajuda na redução das distâncias, mas também contribui para fragmentar mais ainda os horários e distribuí-los em várias unidades. Obviamente outros fatores entram nessa questão, a escolha de atuar em mais uma escola também parte dos docentes, há situações de professores que poderiam estar atuando em apenas uma escola e próximo de sua residência, porém outros fatores que competem a ordem urbana e ao ambiente escolar entram como determinantes, como a violência urbana e escolar, as condições da escola, a gestão da unidade e outros.

Portanto, podemos perceber que são os agentes públicos os principais responsáveis pela distribuição territorial dos docentes. Nesse sentido, não queremos aqui usar da racionalidade dos dados para encerrar a questão colocando como solução prática o reordenamento territorial desses sujeitos, tal ação isolada do todo não é capaz de gerar diminuição da precarização, pelo contrário, isolar os sujeitos em seus municípios de moradia ou em apenas uma escola sem que se modifique a questão salarial e as demais condições de trabalho pode contribuir para uma pauperização ainda maior. Mas é importante pontuarmos esta questão da distribuição como algo crucial para se pensar não só em uma política de mobilidade que privilegie o bem estar dos sujeitos, mas também como uma política trabalhista. A pergunta 
fundamental nesse sentido é por que esse tipo de questão não é pauta prioritária da luta docente?

Sabe-se que as brechas existentes nas leis corroboram para esse leilão de vagas pelo território fluminense e nacional, pois como vimos, os dados mostram que o acúmulo de escolas não é uma realidade exclusiva da MMRJ. Também é sabido que a alta rotatividade docente entre as escolas da mesma rede ou até entre outras redes através de exoneração, nomeação, contratação reduz significativamente o engajamento dos indivíduos e o estabelecimento de vínculo com o local. Além disso, o poder de organização dos movimentos sociais esbarra frequentemente em ações coercitivas e que acabam gerando desagregação e maior individualismo, algo cada vez mais característico da vida urbana. Também encontramos a falta de apoio da população em relação às pautas docentes. Além da ampliação da retirada de autonomia do professorado. Desse modo, há muitos entraves ao fortalecimento sindical e diante de um cenário que retira os direitos mais básicos destes profissionais, há de se reconhecer que falar em uma redistribuição e aumento de salários é algo cada vez mais distante de se tornar real. $\mathrm{O}$ avanço das medidas neoliberais e o agravamento desses problemas fazem com a sobressaia a questão financeira, sem que se considere os impactos de certas políticas nas cidades.

Para pensarmos uma política de mobilidade voltada para estes professores é preciso levar em consideração que os fluxos casa-trabalho e escola(s)-escola(s) se misturam no espaço e formam a rede confusa que vimos nos mapas anteriores. Além disso, os mapas mostram apenas uma generalização dos fluxos levando em conta a mobilidade intermunicipal na escala intrametropolitana, pois se o Censo Escolar oferecesse os turnos de trabalho em cada escola e se fôssemos considerar suas respectivas localizações, teríamos um mapeamento tão complexo que seria difícil a compreensão.

Isto mostra o quanto são necessárias políticas que contemplem o trabalho docente nas suas múltiplas facetas e implicações. No Brasil não há uma forte tradição em se estudar a fundo às questões que tangem o território e os aspectos cotidianos da vida

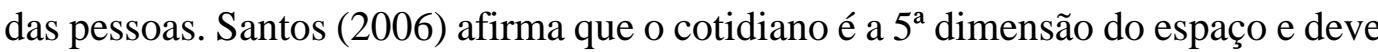
ser levado em consideração para se compreender a aceleração contemporânea. Sem essa compreensão não é possível pensar em uma boa governança territorial, econômica, social e nem estabelecer conexões entre a escala local e as escalas superiores. Sem estudos sobre as macro e microrregiões não se define, implementa 
e acompanha políticas urbanas ou laborais. O que vigora hoje no país são inúmeras leis e estatutos fragmentados e frequentemente reformulados em prol de alguns setores do mercado e que acabam por criar privilégios para uma minoria e agonia para muitos.

Santos (1987) afirma que no sistema capitalista, a cidadania vem sofrendo retrocessos em matéria de conquistas sociais e políticas. Os valores passam a ser distorcidos imperando uma vitória do consumo sobre a solidariedade e comunhão. A busca pelo status, a educação tornando-se cada vez mais precária, são apenas alguns dos problemas imersos em um conformismo anestesiante e paralisante diante da luta a favor dos direitos essenciais para uma vida digna.

Segundo o autor, os direitos de cidadania são tratados de forma perversa em alguns lugares do mundo, sobretudo países de terceiro mundo. O processo de construção histórico brasileiro não privilegiou os ideais de cidadania. $\mathrm{O}$ desenvolvimento acelerado e não planejado das metrópoles, os movimentos migratórios, o consumo de massa, o monopólio da mídia, o descaso com a educação e a fragilidade do sistema político democrático tornou o cidadão mero consumidor. Diz ele: "Em lugar de cidadão formou-se um consumidor que aceita ser chamado de usuário" (SANTOS, 1987, p.25). Talvez por isso, os meios de transporte e os estudos de mobilidade, cada vez mais voltados para as técnicas e para a melhor circulação econômica, chamem as pessoas de usuários também.

Essa lógica não só favoreceu a segregação sócio-espacial, mas também produziu o espaço do não-cidadão, ocasionando uma falsa sensação de liberdade na sociedade. Tal pseudoliberdade e os não-cidadãos nascem como resultado da mercadificação da vida social, onde os direitos básicos (as mediações de primeira ordem como disse Meszáros) se tornam comerciais. Assim, o que predomina nas cidades é uma brutal competitividade e que faz surgir uma sociedade alienada, como afirma Santos (1987). Assim, diz ele, quando os direitos essenciais não são garantidos é que surgem os problemas em relação à cidadania.

(..) somos tragados na economia dos fluxos velozes, que dizem respeito à qualidade de nosso acesso a bens e serviços materiais e simbólicos inscritos nos lugares, mas, sobretudo, agenciam quem somos, por meio das escalas geográficas que habitamos. (...) É por isso que o debate contemporâneo sobre a mobilidade coloca em questão as espacialidades discricionárias da economia dos fluxos velozes no âmbito do ordenamento de lugares e territórios, assim como vem se configurando como esfera pública de disputa política. Afinal de contas, a mobilidade tem a ver com 
os lugares em que podemos ir e vir, morar e trabalhar, festejar e ser felizes. Portanto, tem a ver com a condição que faz possível a apropriação, o uso e o viver em espacialidades de significado social para nós mesmos e para os outros diferentes de nós. Tratase, como alude Harvey, da mobilidade como direito de produzir o espaço da cidade. (BARBOSA, 1980, p. 50)

Esse direito de produzir o espaço não é somente de circular em seu interior, mas de transformá-lo em um espaço de ação estabelecendo novas relações espaciais (formas, recursos, regras) que superem os enclaves territoriais (HARVEY, 2004 apud BARBOSA, 2016). Desse modo, é preciso pensar a mobilidade como um direito à cidade. Indivíduos que são obrigados a se deslocar constantemente nas condições que são impostas na mercantilização do espaço ou aqueles que não possuem essa possibilidade de percorrer os lugares são constantemente usurpados em seus direitos pelos agentes econômicos. É preciso pensar que tanto a mobilidade quanto o trabalho podem tornar concretas as possibilidades de realização da vida social (BARBOSA, 2016) e isso depende da mobilização para transformação do urbano.

\subsection{A mobilidade dos professores no cotidiano}

Como falado, os estudos quantitativos sobre os deslocamentos não são capazes de dar conta da percepção individual sobre a mobilidade nas cidades. Nesse sentido, consideramos importante fazer um breve levantamento com os professores, através de questionário online, sobre os desdobramentos dessa mobilidade em cotidiano. $\mathrm{O}$ questionário completo encontra-se no anexo 1.

Com isso, obtivemos as seguintes respostas:

\begin{tabular}{|c|c|}
\hline \multicolumn{2}{|r|}{ Panorama das respostas do questionário } \\
\hline Sexo & $55 \%$ eram mulheres e $45 \%$ homens \\
\hline Faixa etária & a maior parte tinha entre 30 a 39 anos $(35 \%)$ \\
\hline Formação & $29 \%$ possuía licenciatura, $35 \%$ pós-graduação e $22 \%$ mestrado \\
\hline Disciplina & Docentes de todas as disciplinas responderam ao questionário. \\
\hline Turmas & $\begin{array}{l}79 \% \text { atua no ensino fundamental, } 68 \% \text { no médio e } 6,8 \% \text { em cursos técnicos e } \\
17 \% \text { em cursos preparatórios. }\end{array}$ \\
\hline $\begin{array}{l}\text { Tempo no } \\
\text { magistério }\end{array}$ & $\begin{array}{l}\text { A maior parte dos respondentes atua no magistério há menos de } 10 \text { anos (entre 1- } \\
\qquad 5 \text { anos } 23 \% \text { e entre } 6-10 \text { anos } 23 \% \text { ) }\end{array}$ \\
\hline Trabalho & Para $85 \%$ dos docentes a carreira do magistério é a única fonte de renda. \\
\hline
\end{tabular}


Tempo de $17 \%$ trabalha menos de 20 horas semanais, $27 \%$ trabalham cerca de 20 a 30 horas trabalho semanais, $26 \%$ entre 30 a 40 horas, $17 \%$ entre 40 a 50 horas e $8,2 \%$ entre 50 a 60 horas.

Quadro 11: Panorama das respostas do questionário online. Fonte: própria. Elaborado pela autora.

Para isso, o tempo e a distância foram categorias privilegiadas nesta pesquisa, pois como falado a possibilidade de transitar pelos lugares é característica da nossa era (BARBOSA, 2016). Como vimos, os fluxos interescolas representam uma realidade para grande parte dos professores da RMRJ. O mapa abaixo foi realizado com base no Censo Escolar 2018 e ilustra as maiores e menores distâncias percorridas e na escala intrametropolitana, bem como os principais eixos integrados.

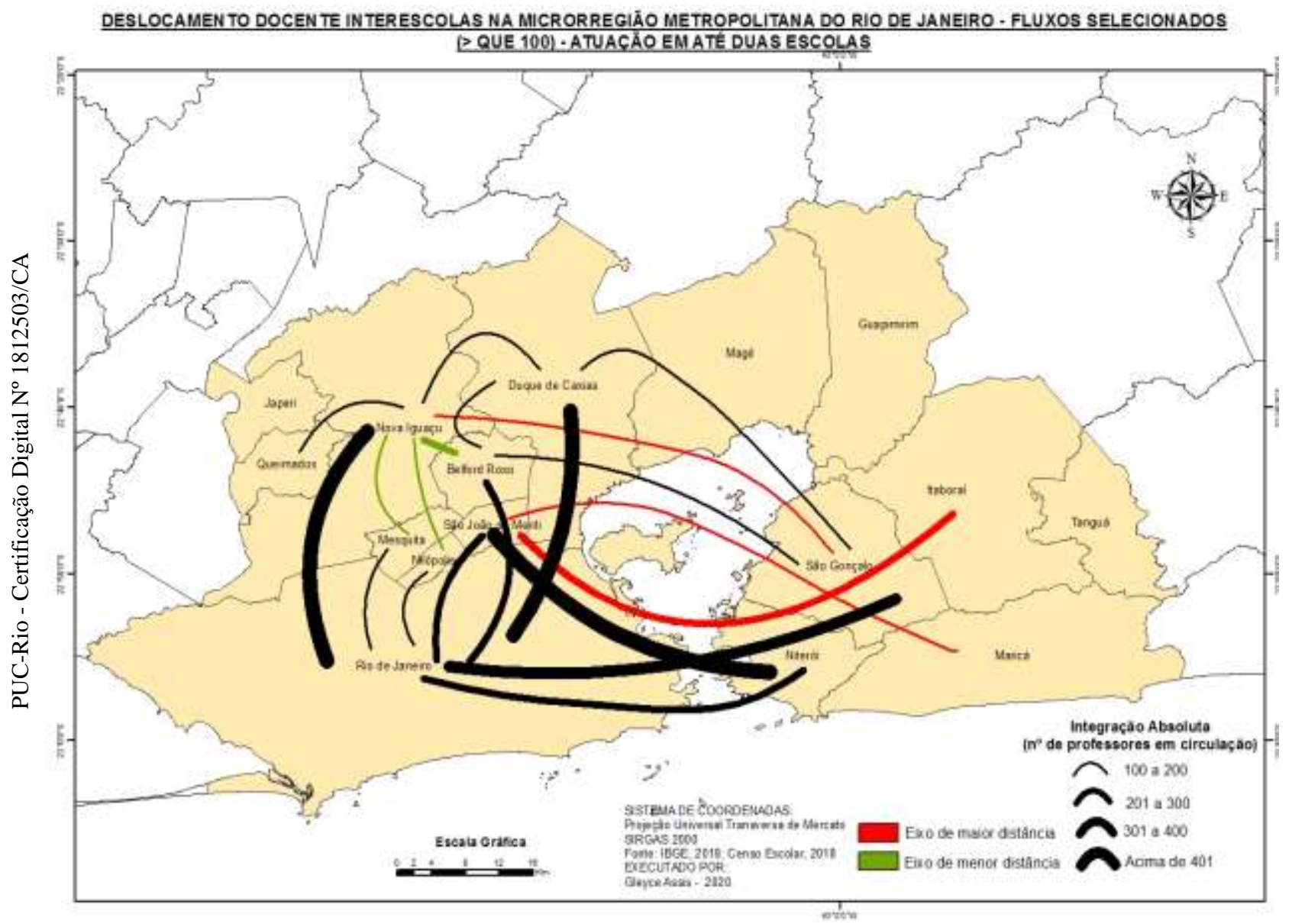

Mapa 10: deslocamento docente interescolas na MMRJ - docentes que atuam em até duas escolas. Fonte: Censo Escolar 2010. Elaborado pela autora.

Os fluxos traçados levam em conta os trajetos acima de 100 indivíduos e não consideram a direção do município A para o B e todos os fluxos que existem entre os dois. Além disso só considera o deslocamento de professores que atuam em até duas escolas. Podemos notar que as áreas periféricas exercem conexões entre si, inclusive com municípios de maior distância, por exemplo, o eixo São João de 
Meriti à Maricá representa cerca de 76 km de distância, e São João de Meriti à Itaboraí são $69 \mathrm{~km}$. Vale lembrar que esses trajetos de maior distância não simbolizam só maior tempo para chegar ao trabalho, mas também maior custo, o que pode representar uma fatia significativa dos salários em comparação àqueles que percorrem o mesmo município, ou municípios de menor distância.

Notamos também que Nova Iguaçu é o local que exerce maior número de conexões de menor distância, o que talvez indique que os docentes que trabalham nestes municípios conectados possam ter mais de um deslocamento interescolas ao longo do dia, pela proximidade e extensão dos municípios que exerce integração.

No questionário aplicado aos professores, perguntamos se necessitou mudar de residência para estar mais próximo ao trabalho, $17 \%$ responderam que sim e $83 \%$ que não. Também perguntamos se já necessitou morar ou dormir alguns dias da semana em uma residência temporária por causa do trabalho, $35 \%$ responderam que atualmente não, mas já precisaram, 64\% respondeu que não. Também indagamos se o docente já havia realizado permuta, $28 \%$ responderam que sim, por causa da proximidade ao local de moradia, $7,4 \%$ responderam que sim por outros motivos, $7,4 \%$ não realizaram, mas já solicitaram e 57,1\% responderam que não. Vale dizer que este tipo de prática é tão comum que há diversos grupos nas redes sociais com centenas de membros para realizar trocas intermunicipais e interestaduais dentro da rede pública, muitas vezes significando até renunciar a uma maior remuneração para mudar de localidade.

Ainda nesta perspectiva da distância, foi perguntado se teve que adquirir algum veículo para se locomover para o trabalho, $47 \%$ responderam que sim e $52 \%$ que não. Indicando que partes dos docentes podem trabalhar perto de onde moram e outros necessitam de um veículo pela distância ou dificuldade de acesso ou pela questão de atuar em diversas escolas. O meio que escolhemos se traduz em uma atividade lucrativa da mobilidade atual. $\mathrm{O}$ aumento da circulação da mão de obra nas cidades gera lucro em diversos setores, indústria automobilística, aplicativos de viagens, meios de transportes, seguradoras, estacionamentos e outros setores que se inserem indiretamente no mercado da mobilidade. Um ciclista por exemplo, gera lucro para a empresa de bicicleta e ainda reduz os gastos com saúde e talvez por isso o planejamento das cidades não incorpore esse tipo de transporte como um veículo de massa, tampouco disponibiliza infraestrutura que favoreça uma mobilidade mais sustentável e menos mercadológica. 
O fator distância relaciona-se ao desgaste físico não só pelo tempo da viagem em si, mas porque em alguns eixos há necessidade de diversas integrações de modais para aqueles que utilizam transporte público. Porém, consideramos que o maior impacto que a mobilidade pode acarretar a vida das pessoas referem-se ao tempo. Este é um definidor de como organizamos a vida.

Rosso (2017) explica que esse processo de maleabilidade do trabalho tem forte relação com o tempo. São os horários que organizam o mundo, portanto, o trabalho como ação criada pelo homem não foge à regra do tempo. Tal flexibilização não marca uma diminuição do trabalho, mas sim o transforma para que pareça favorável e uma livre escolha do trabalhador. A profissão docente encontra respaldo legal para essa percepção ilusória de maior possibilidade de acúmulo de empregos, sem revelar nitidamente que se trata de um processo de controle e programado para torná-lo exaustivo, desvalorizado e sem qualidade. Embora o trabalho do professor no espaço escolar seja marcado por forte rigidez e segmentação por tempos de aula, a forma de contração e suas funções muitas vezes não são igualmente fixadas.

Resgatando o sentido de mobilidade na perspectiva de Marx e Gaudemar (1977), aponta que isto é a verdadeira especificidade do deslocamento da força de trabalho, pois ela é a única mercadoria que se desloca por conta própria. Ele entende que esses indivíduos são livres para circular vendendo a sua mercadoria, ou seja, sua própria força de trabalho. Felix (2019) denomina esse tempo de deslocamento da mercadoria como tempo de circulação. Afirma ele: "os próprios espaços de movimento e de deslocamento são também espaços de reprodução, que, dependendo da distância e do tempo envolvidos, implicam elevação dos custos da reprodução da força de trabalho." (FELIX, 2019, p. 232).

\begin{tabular}{|c|c|c|}
\hline \multicolumn{3}{|c|}{ Tempo médio de deslocamento por semana - \% de professores } \\
\hline Em horas & casa - trabalho & Interescolas \\
\hline Até 5 & 61,64 & 86,3 \\
\hline 05 a 10 & 21,92 & 9,59 \\
\hline 10 a 15 & 12,33 & 4,11 \\
\hline 15 a 20 & 2,74 & 0 \\
\hline Acima de 20 & 1,37 & 0 \\
\hline
\end{tabular}

Tabela 9: Tempo médio de deslocamento por semana dos professores entrevistados. Fonte: própria. Elaborado pela autora.

Nesse sentido, foi indagado aos professores sobre o tempo médio de deslocamento por semana. Tomamos como base os dados informados pelo IBGE sobre o 
deslocamento na cidade do RJ, cujo tempo médio é de 40 a 50 minutos/dia (somente ida), para definir os intervalos das perguntas do questionário sobre o tempo de deslocamento. Assim, levando em consideração que a jornada de trabalho deste professor seja de 40 horas semanais, teríamos em média de 7 a 10 horas somente de deslocamento casa-trabalho por semana. Sem contar o tempo interescolas. Este tempo de deslocamento não é incorporado ao trabalho.

Como aponta Félix (2019), os salários remuneram a força de trabalho somente no que se refere às horas trabalhadas (tempo de produção) e não a circulação destas pessoas (momento de reprodução). $\mathrm{O}$ autor defende que este tempo precisa ser incorporado aos salários para que essa força de trabalho não perca ainda mais o seu valor.

É preciso ressaltar que tempo de produção não se confunde com jornada de trabalho. O tempo de produção se refere ao período no qual a mercadoria força de trabalho foi vendida e não ao tempo de duração da jornada de trabalho. O tempo de produção compreende tanto às horas voltadas para a jornada de trabalho quanto as horas de descanso (horas de não trabalho) do trabalhador ao longo do período em que ele vende a força de trabalho para o capitalista. (FÉLIX, 2019, p. 239)

Nesse sentido, a mobilidade mostra-se tão importante quanto a própria produção, pois ela é condição para que o processo produtivo ocorra. Porém, quando falamos do trabalho docente é preciso pontuar que assim como esse tempo de deslocamento não é agregado ao tempo de trabalho, as funções de planejamento das atividades escolares, correção de prova, o tempo de espera entre turmas, os intervalos também não são contabilizados. Sobretudo na rede privada, pois a remuneração docente em geral se dá por hora aula e apenas na rede pública há uma redução da jornada em sala de aula para incorporar na remuneração às atividades extras-classe.

No que se refere à circulação da força de trabalho, mesmo que o trabalhador perceba a ausência de salário ou o aumento do tempo de circulação como empobrecimento, ainda assim a forma salário também é normalmente um mascaramento do rebaixamento do preço da força de trabalho a níveis inferiores do próprio valor da força de trabalho. (Ibidem, p.240)

Sobre a remuneração pelo deslocamento, vale dizer que não há uma legislação específica que obrigue a rede pública a oferecer auxílio deslocamento, embora isso ocorra nas demais profissões. Em geral, grande parte dos trabalhadores assalariados recebem pelo deslocamento casa-trabalho. No caso da categoria dos professores, 
não foram encontrados registros de projetos de lei que contemplam financeiramente o deslocamento entre as redes de ensino e até mesmo o deslocamento casa-trabalho, embora seja comum existir este último descontando parcialmente do salário. A súmula $90^{\circ}$ do TST (BRASIL, 2005), chamada de horas “in tinerere”, que previa uma remuneração para os trabalhadores por tempo de deslocamento, ficou fora da reforma trabalhista de 2017 no Governo Michel Temer. Mas outra questão se impõe: mesmo que fosse contemplada, isso diminuiria o desgaste que essa mobilidade causa? É preciso pensar que o fator financeiro corrobora para o estabelecimento de garantias trabalhistas, mas não necessariamente dilui a precarização, pois a precariedade é uma problemática que envolve também a percepção perante as demais carreiras, ao reconhecimento social, aos tipos de contrato, ao tipo de trabalho, entre outros aspectos.

Outra questão que também pode ser relacionada tanto com a busca por maiores salários quanto a redução da circulação são os programas de hora extra (GLP, janela e outros). Nesse sentido, ao perguntarmos se o docente já havia participado desse tipo de contrato, $36 \%$ afirmou que estavam participando, $36 \%$ nunca participaram e $26 \%$ já participaram sobretudo na rede estadual. Muitos optam por esse tipo de contrato para evitar ter que diluir suas horas de trabalho em diversas escolas e principalmente por obter uma remuneração complementar.

Outro ponto tratado na pesquisa foi verificar como é esse tempo do deslocamento, uma vez que essa percepção individual das viagens cada vez mais torna-se comum nas cidades. Hoje as políticas públicas discutem junto aos agentes privados como melhorar o sistema de transporte para que pessoas e mercadorias possam circular mais rápido, a velocidade se tornou uma constante meta a ser ultrapassada, até que a vida esteja tão acelerada que não conseguiremos senti-la. Assim, cada vez mais os percursos tornam-se lugares na vida das pessoas. Nesse sentido, perguntamos se nos trajetos os professores exerciam alguma atividade relacionada ao seu trabalho, 55\% disseram que faziam atividades como planejar aula, correção de prova, leitura e outra e $45 \%$ disseram que não, justamente aqueles que se locomovem de carro.

A dimensão temporal tem grande importância nesse processo, uma vez que os avanços das técnicas proporcionaram grandes compressões do espaço e do tempo. Para Paul Virilio (1993), a velocidade passou a dissolver a cidade. Esse "tempo morto" ou esse tempo da viagem tornou-se um lugar. Para ele, uma cidade não é simplesmente um lugar onde se vive, ela é acima de tudo uma encruzilhada. Desse 
modo, a cidade não é apenas um lugar, mas também são as experiências em que se produz subjetividade. Completa Augé (2010):

Pensar a mobilidade no espaço, mas ser incapaz de concebê-la no tempo, essa é finalmente a característica do pensamento contemporâneo preso na armadilha de uma aceleração que o entorpece e o paralisa. Mas, por isso mesmo, é no espaço que ela denuncia inicialmente sua imperfeição. (Augé, 2010, p.102)

Como dito, a metrópole fluminense possui um dos maiores tempos de deslocamento para o trabalho e isso tem impacto direto na percepção dos indivíduos sobre a cidade e os trajetos. A sensação de angustiante de cidade pode ser maior entre aqueles que se deslocam em um transporte público na hora do rush, por exemplo, embora o automóvel também provoque grandes congestionamentos, a sensação de uma viagem precária pode ser menor devido a imagem do automóvel como status social. Também há diferentes percepções por aqueles que se deslocam em transportes públicos em horários de contrafluxos, em trajetos menos procurados, em transportes mais confortáveis ou silenciosos, aqueles que podem ler e aqueles que não podem, aqueles que pegam mais de um modal e aqueles que se deslocam em apenas um, aqueles que se movem a pé, em pé e aqueles que se movem de bicicleta, moto, etc.

Nesse sentido, pensar a mobilidade exige compreender que os deslocamentos não são mais vistos somente como meio de se chegar a um destino, como aponta Balbim (2016), tampouco é um tempo perdido entre duas situações produtivas. Para o autor a comunicação e a informação passam a ter papel central na percepção do deslocamento e na forma que ele ocorre também. Diz ele: "O "tempo perdido", querem muitos, poderia ser recuperado com o consumo, sobretudo através dos smartphones" (BALBIM, 2016, p.39). Desse modo, "não ver o mundo", como disse Milton Santos sobre a mobilidade, não se dá somente pela aceleração anestésica atual, mas também pela hipnose das telas.

Assim, para adentrarmos nas percepções dos docentes sobre os deslocamentos, perguntamos se acreditam que trabalhar em uma só escola poderia melhorar sua condição de trabalho, $69 \%$ afirmaram que sim, $26 \%$ parcialmente e 5,4\% disseram que não seria melhor em nada. Além disso, indagamos quanto que a mobilidade impacta no trabalho enquanto professor, $11,27 \%$ afirmaram que em nada, $9 \%$ pouco e $36 \%$ parcialmente e $42 \%$ muito.

Nesse sentido, vemos a multiplicidade de experiências de mobilidade. Retomando Balbim (2016), o movimento das pessoas é carregado de significados. Para o autor 
estar em movimento possui duas dimensões: uma objetiva que se liga à locomoção e outra subjetiva que se refere a reprodução urbana das relações sociais. Assim, as transformações na mobilidade tomam o sentido individual, típico da sociedade contemporânea.

Segundo ele, no cotidiano a mobilidade é cada vez maior e menos previsível, ao mesmo tempo que é cada vez mais controlada e organizada e isto se relaciona intimamente à sociedade de consumo e as transformações do modo de produção de cada local. Além disso, há outros aspectos para explicar essa mudança na mobilidade.

Além disso, existem também as revoluções nas técnicas de transporte, as transformações da urbanização (desconcentração e periferização) e do mercado de trabalho - inclusive com a maior inserção das mulheres -, a redução da jornada de trabalho e o trabalho à distância; enfim, uma profunda multiplicação e dessincronização do tempo social, em agendas cada vez mais múltiplas e complexas, as quais se realizam no entorno das inovações da comunicação e da informação, que - como já citado - transformam o conjunto das relações humanas. Todos esses fatores multiplicam, pois, as oportunidades de vida na cidade intensificam a mobilidade cotidiana ao menos daqueles que têm o direito à cidade (BALBIM, 2016, p.37).

Nesse sentido, ele explica que teríamos passado de uma mobilidade fordiana, onde os deslocamentos aconteciam entre frações de tempo claramente definidas na jornada de trabalho para um modelo flexível, onde os deslocamentos seguem ritmos específicos. Vimos isso em relação aos professores, com sua especificidade de fluxos.

Isso não significa que os movimentos pendulares deixaram de existir, mas estes perdem participação na totalidade dos deslocamentos, em razão de diversos fatores ligados a questões de ordem técnica, social, econômica, cultural, normativa etc. Entre os processos de transformação da mobilidade cotidiana, está o fato de que os deslocamentos não são mais interpretados somente como um meio de chegar até o destino, ou até mesmo como tempo perdido entre duas situações produtivas. Novamente, comunicação e informação transformaram por completo o tempo do deslocamento (BALBIM, 2016, p. 40).

O autor afirma que essa mobilidade cada vez mais intensa e flexível não contempla a todos, exige bastante daqueles que se inserem nesse novo mercado da força de trabalho. Ao mesmo tempo que se torna um antagonismo àqueles que vivem em 
relativa imobilidade, ou seja, os desempregados ou os que trabalham em setores tradicionais da economia.

Desse modo, temos a vida cada vez mais organizada pela mobilidade das pessoas. "O cotidiano passa a ser cada vez mais pautado, agendado, controlado e, enfim, determinado por um tempo passível de ser minuciosamente parcelado, em um espaço finamente esquadrinhado.” (BALBIM, 2016, p. 40) 


\section{Considerações finais}

Como falado, estamos diante de uma aceleração como nunca se viu antes. Na metrópole a vida corre depressa, fluxos diversos se cruzam, ela incha em determinados horários e itinerários, e esvazia em outros. Assim, o modo de vida marcado pela alta mobilidade se desenrola em uma cena do capital financeiro que provoca crescimento da urbanização, em um processo denominado metropolização do espaço.

Paralelo a isso, o mercado de trabalho também passou por diversas transformações. O aumento da volatilidade e da competitividade impôs aos trabalhadores regimes de trabalho mais flexíveis. Assim, a redução do emprego regular e o aumento do trabalho em tempo parcial, temporário e outros, geraram enorme impacto sobre a força de trabalho, especialmente pela precarização. Com isso, esses indivíduos passaram a buscar estratégias de mobilidade espacial para sua reprodução. Isso contribuiu para o aumento das jornadas de trabalho, ou seja, o tempo produtivo somado ao tempo de circulação.

A mobilidade não é somente o deslocamento, ela envolve a experiência urbana e possui relação com as características de quem se desloca. Engloba as decisões políticas, porque nela se inserem relações desiguais de acesso aos espaços. Essa desigualdade se dá pela dualidade de processos que permeiam o conceito, a mobilidade e a imobilidade, ou seja, aqueles que necessitam se mover e aqueles que não podem.

Sobre isso Barbosa (2016) nos impõe uma pergunta fundamental: "será que somos o que somos pela velocidade que temos?" Pensando na dimensão da mobilidade dos trabalhadores, percebe-se de cara a condição espacial de três tipos de grupos: aqueles que se deslocam em excesso acompanhando a fluidez das cidades e do mundo atual, como professores, médicos, trabalhadores de entregas, motoristas de aplicativos, autônomos, entre outros; aqueles que não podem se deslocar pela inacessibilidade dos meios de transportes em determinados locais ou que se tornam imóveis pela dificuldade de custear seu próprio deslocamento, já que o direito de ir e vir torna-se cada vez mais restrito pelo mercado. E aqueles que compõe a minoria, não possuem barreiras físicas, técnicas e econômicas, nem a obrigatoriedade de circulação para o trabalho e que poderão usufruir de uma mobilidade positiva com 
livre acesso aos lugares e sobretudo com tempo de vida disponível. Estes possuem o privilégio de não se mover e detém o poder para isso quando desejarem.

Nas metrópoles essa lógica é reproduzida ao retirar a acessibilidade aos meios de transportes ou mesmo ao precarizá-los em algumas regiões. Assim como a obrigação das longas viagens para o trabalho ou estudo funcionam como processos excludentes e ampliam a divisão de classes. Desse modo, aqueles que se locomovem como força de trabalho podem ser inseridos como precariados por uma dupla explicação: os fluxos que ocorrem nesse espaço urbano mercantilizado são degradantes, tanto pelo tempo que se perde, quanto pelas condições que ele se dá, ou seja, tornam as pessoas completamente destituídas de cidadania. E a segunda é que apesar de serem livres para circular, eles não detêm os meios de produção, assim deslocam-se para vender sua força de trabalho.

O que se tem hoje é que a lei populacional de Marx do exército industrial da reserva e o rebaixamento de salários deixa de ser o determinante para a mobilidade, como aponta Barbosa (2016) há diversas mobilidades, com diferentes motivações, para o lazer, estudo e outras. Porém, não se pode dizer que os docentes que se deslocam façam isso em total liberdade e que a necessidade de se deslocar para vender sua força de trabalho tenha desaparecido. Professores que trabalham em três ou mais escolas por dia certamente não se submetem a essa jornada por decisão própria sem nenhuma influência da necessidade. Desse modo, para além das categorias classificadas neste trabalho como precariados, apontamos aqui que aqueles que se deslocam frequentemente interescolas também se enquadram nesse grupo.

Consonante a isso temos a mobilidade ocorrendo em condições insuportáveis, tendo dois grandes entraves: o custo e o tempo de deslocamento. Assim, a distância entre centro-periferia, as péssimas condições de transporte a ampliação dos contatos e empregos gerados na era da flexibilidade, transformaram a mobilidade em um meio de reprodução de desigualdades entre os lugares e pessoas, sem cumprir seu objetivo central que é proporcionar acesso democrático. Assim, torna-se um meio precarizante da vida. Nesse sentido é preciso conceber a mobilidade na dimensão política.

Barbosa (2016) aponta que a mobilidade teria três dimensões: sociológica, circulação de bens e pessoas, e socioespacial, que ao mesmo tempo que incorpora essas duas busca superá-la para se pensar uma política de cidade. Nesse sentido, pensar em políticas de mobilidade que incluam tais indivíduos faz-se urgente para 
a minimização destes problemas e para multiplicação de modelos democráticos de cidades.

A política urbana brasileira foi historicamente municipalizada. Assim como a educação brasileira também foi. Há um grande descompasso entre a políticas no que tange o trabalho docente e no que se refere à mobilidade. $\mathrm{O}$ arranjo urbano regionalizado em micro e mesorregiões não é incorporado na prática ao seu sentido original. Poucas são as políticas integradoras e que pensam um planejamento urbano para além dos interesses de mercado. Atualmente existe um arcabouço legal recente como o estatuto da cidade e a política nacional de mobilidade urbana que ainda está engatinhando nas cidades, a partir disso surge uma questão, se temos ferramentas legais por que ainda não implementamos? Como podemos tornar as cidades mais saudáveis?

Pensar o trabalho integrado à uma política de cidade que leve bolsões de emprego aos municípios de moradia nos parece um dos caminhos, mas sabemos que isso esbarra na própria fase de reestruturação econômica que impõe a flexibilidade como uma condição para o trabalho e para o processo produtivo. Assim, o agravamento dessas condições de trabalho mostra que a tendência atual é de diluição do pêndulo casa-trabalho e aumento do pêndulo casa-trabalhos, o que demonstra uma aceleração dos fluxos.

Desse modo, nas cidades há um somatório de precarizações que tornam a experiência de viver no urbano muito angustiante. A vulnerabilidade das pessoas resulta na precarização da vida. Os resultados das análises feitas ao longo dessa pesquisa demonstram o quanto esta categoria encontra-se imersa em diversas redes e mecanismos que pressionam a deterioração do trabalho e isso perpassa antes de tudo pelo projeto de uma educação sem valor.

Como aponta Mészáros (2014) o desmonte da educação trata-se de um processo ideologicamente articulado, não só para obtenção de lucro, mas também pela manutenção do mecanismo de alienação, uma vez que a educação é um dos meios de ruptura com a lógica dominante de exploração. Nesse sentido, ao desvalorizar os professores têm-se igual desvalorização da educação, do trabalho imaterial, intelectual e consequentemente maior controle destes profissionais e dos indivíduos que são formados por estes.

Apontamos aqui o regime de carga horária dos municípios e estados totalmente diferenciados, e as desigualdades internas no que tange à situação salarial, 
contratual e de carga horária, como um dos principais problemas gerados na esfera educacional que impacta no trabalho, no cotidiano dessas pessoas e também na mobilidade. O pagamento por hora aula e a possibilidade de acúmulo de empregos faz parecer ao trabalhador detentor de maior flexibilidade, mas ao contrário, contribuiu para enormes desigualdades internas e aumento da precarização.

Assim, temos a configuração atual das relações de trabalho combinada a um processo de fragmentação do espaço-tempo colaborando com significativas mudanças na organização, nos regimes de contratação e nas condições de trabalho. Isto acaba sucumbindo o trabalhador na forma de captação subjetiva, atingindo-o emocionalmente e fisicamente, como no caso de problemas de saúde, estigma, desinteresse, até que sua prática se torne alienada e sem valor.

Todavia, essa captura do trabalho não é um processo totalmente acabado e intransigente, a história nos mostra que a insatisfação permitiu que as pressões e as lutas sociais alcançassem conquistas trabalhistas. Embora alguns autores acreditem que é impossível a superação desse sistema dentro do próprio sistema, a história mostrou em diversos momentos avanços para garantias de direitos e reconhecimento dos trabalhadores, sobretudo em países desenvolvidos.

Nesse sentido, em uma era de grandes mudanças no mundo do trabalho torna-se relevante estudos que mostrem o impacto dessas transformações no espaço, principalmente no Brasil, onde esse processo corre a passos largos e empurra a população para condições de vida predatórias. Portanto, faz-se urgente pensar em saídas para o mundo do trabalho e para a vida urbana, pois é preciso conhecer as contradições, inventar possibilidades e transformá-las. 


\section{Referências Bibliográficas}

ALVES, Giovanni. Trabalho, corpo, subjetividade. Toyotismo e formas de precariedade no capitalismo global. Trabalho, Educação e Saúde, v.3 n.2,p.4009-428, $2005 . \quad$ Disponível em: https://www.scielo.br/scielo.php?pid=S1981-

77462005000200009\&script=sci_arttext. Acessado em outubro de 2018.

ALVES, Thiago; SONOBE, Aline Kazuko. Remuneração média como indicador da valorização docente no mercado de trabalho. Cad. Pesqui. São Paulo, v. 48, n. 168, p. 446-476, jun. 2018 . <Disponível em: $\quad$ http://www.scielo.br/scielo.php?script=sci_arttext\&pid=S010015742018000200446\&lng=pt\&nrm=iso >. Acessado em: 10 ago. 2020

ANTUNES, Ricardo. Os sentidos do trabalho. Boitempo: 1999.

, DRUCK, Graça. A epidemia da terceirização. In: ANTUNES, Ricardo (Org.). Riqueza e miséria do trabalho. São Paulo: Boitempo, 2014. v. III, p. 13-24.

. Coronavirus: o trabalho sob fogo cruzado. Boitempo. São Paulo: Boitempo; 2020. ISBN: 978-65-5717-0001-4

ARAÚJO, Raimundo Luiz Silva. Limites e possibilidades da redução das desigualdades territoriais por meio do financiamento da educação básica. 2014. Tese (Doutorado em Educação) - Faculdade de Educação, Universidade de São Paulo, São Paulo, 2014. doi:10.11606/T.48.2014.tde17122014-114038. Acesso em: 2020-11-10.

AUGÉ, Marc. Por uma antropologia da mobilidade. Maceió. EDUFAL: UNESP, 2010.

BALBIM, R; KRAUSE, C; LINKE, C. Cidade e Movimento: Mobilidade e interações no desenvolvimento urbano. Brasília: IPEA: ITDP, 2016. Disponível

em:

https://www.ipea.gov.br/portal/images/stories/PDFs/livros/livros/160905_liv ro_cidade_movimento.pdf. Acesso em março de 2019.

BALL, Stephen J. Educação Global S. A.: novas redes de políticas e o imaginário neoliberal. Tradução de Janete Bridon. Ponta Grossa: UEPG, 2014. $270 \mathrm{p}$.

BARBOSA, Jorge Luiz. O Significado de mobilidade na construção democrática de cidade. In Cidade e Movimento: Mobilidade e interações no desenvolvimento urbano. Brasília: IPEA: ITDP, 2016. Disponível em: https://www.ipea.gov.br/portal/images/stories/PDFs/livros/livros/160905_liv ro_cidade_movimento.pdf. Acesso em março de 2019.

BEAUJEU-GARNIER, J. Geografia da população. São Paulo: Companhia Editora Nacional, 1980. 
BECKER, Olga Maria Schild. Mobilidade espacial da população: conceitos, tipologia, contextos. In: CASTRO, Iná Elias de et al. (Orgs.). Explorações geográficas. Rio de Janeiro: Bertrand Brasil, 1997. p. 319-367.

BRAGA, Ruy. A rebeldia do precariado: trabalho e neoliberalismo no Sul global, São Paulo: Boitempo, 2017.

BRASIL - Ministério da Educação [MEC]. Instituto Nacional de Estudos e Pesquisas Educacionais Anísio Teixeira. Resumo Técnico : Censo da Educação Básica 2018 [recurso eletrônico]. - Brasília : Instituto Nacional de Estudos e Pesquisas Educacionais Anísio Teixeira, 2019.66p.:il. $<$ Disponível

em:

http://download.inep.gov.br/educacao_basica/censo_escolar/resumos_tec nicos/resumo_tecnico_censo_educacao_basica_2018.pdf> Acesso em: 11 de ago 2020.

BRASIL, Ministério da Educação [MEC], Instituto Nacional de Estudos e Pesquisas Educacionais Anísio Teixeira. Indicador de Esforço Docente. Brasília, 17 de dezembro de 2014.<Disponível em:

BRASIL, Ministério da Educação [MEC]. Indicador de Esforço Docente. Instituto Nacional de Estudos e Pesquisas Educacionais Anísio Teixeira Diretoria de Estatísticas Educacionais[ [INEP]. Nota Técnica no 039/2014. Brasília, 17 de dezembro de 2014

BRASIL, Ministério da Educação [MEC]. Piso salarial. Brasília: 2020. $<$ Disponível

em :.http://portal.mec.gov.br/component/tags/tag/32666?start=0:> Acesso em: 21 de out 2020.

BRASIL, Presidência da República. Casa Civil. Lei oํ 13.005, de 25 de junho de 2014. Plano Nacional da Educação - PNE <Disponível em: http://www.planalto.gov.br/CCIVIL_03/_Ato2011-

2014/2014/Lei/L13005.htm> Acesso em: 20 de Jan 2020.

BRASIL, Presidência da República. Secretária geral. Lei no 12.587, de 3 de janeiro de 2012. Institui as diretrizes da Política Nacional de Mobilidade Urbana. <Disponível em: http://www.planalto.gov.br/ccivil_03/_ato20112014/2012/lei//12587.htm> Acesso em: 19 de jan 2020.

BRASIL, Presidência da República. Secretária geral. Lei no 13.089, de 12 de janeiro de 2015. Institui o Estatuto da Metrópole, altera a Lei № 10.257, de 10 de julho de 2001. <Disponível em: http://www.planalto.gov.br/ccivil_03/_ato2015-2018/2015/lei/13089.htm> Acesso em: 21 de Jan 2020

BRASIL. Constituição da República Federativa do Brasil (1988). Art 7. Brasília, DF: Senado Federal, 1988. <Disponível em: http://www.senado.leg.br/atividade/const/con1988/CON1988_05.10.1988/ art_7_.asp >. Acessado em: 22 mar. 2020. 
BRASIL. Constituição da República Federativa do Brasil (1988). Art 37. Brasília, DF: Senado Federal, 1988. <Disponível em: https://www.senado.leg.br/atividade/const/con1988/con1988_12.07.2016/a rt_37_.asp> Acesso em: 26 de mar 2020.

BRASIL. Controladoria-Geral da União. Portal da transparência. 2020. Brasília, DF, <Disponível em: http://www.portaltransparencia.gov.br/funcoes/12-educacao?ano=2020.> Acessado em: 10 de outubro de 2020.

BRASIL. Lei n. 11.738, de 16 de julho de 2008. Regulamenta a alínea "e" do inciso III do caput do art. 60 do Ato das Disposições Constitucionais Transitórias, para instituir o piso salarial profissional nacional para os profissionais do magistério público da educação básica. Brasil: Casa Civil , 2008.

BRASIL. Lei n. 12.587, de 3 de janeiro de 2012. Institui as diretrizes da Política Nacional de Mobilidade Urbana. Disponível em: http://www.planalto.gov.br/ccivil_03/_Ato2011-2014/2012/Lei/L12587.htm. Acesso em: 11/03/2019

BRASIL. Lei n. 13.005, de 25 de junho de 2014. Aprova o Plano Nacional de Educação - PNE e dá outras providências. Brasil: Casa Civil , 2014.

BRASIL. Lei n. 9.424. Dispõe sobre o Fundo de Manutenção e Desenvolvimento do Ensino Fundamental e de Valorização do Magistério, na forma prevista no art. $60, \S 7^{\circ}$, do Ato das Disposições Constitucionais Transitórias, e dá outras providências. Brasil: Casa Civil , 1996b.

BRASIL. Ministério do Trabalho - MTb. Relação Anual de Informações Sociais (RAIS) Disponível:

http://bi.mte.gov.br/bgcaged/caged_rais_vinculo_id/login.php . Acessado em 20 de julho de 2020.

BRASIL. Ministério do Trabalho e Previdência Social (MTPS). Nota Técnica MTPS 088/12 - Sobre a liberação do acesso aos microdados da Relação Anual de Informações Sociais (RAIS) e Cadastro Geral de Empregados e Desempregados (CAGED) à comunidade usuária. 20/06/2012. Brasília, DF: $\quad$ MTPS, $2012 . \quad<$ Disponível em: ftp://ftp.mtps.gov.br/pdet/microdados/NOTA_TECNICA_microdados.pdf $>$. Acessado em: 15 mar. 2020.

BRASIL. Presidência da República, Lei n 11.738, de 16 de julho de 2008, Brasília, DF, <Disponível em: http://www.planalto.gov.br/ccivil_03/_ato2007-

2010/2008/lei//11738.htm\#: :text=Regulamenta\%20a\%20al\%C3\%ADnea \%20\%E2\%80\%9Ce\%E2\%80\%9D\%20do,magist\%C3\%A9rio\%20p\%C3\% BAblico\%20da\%20educa\%C3\%A7\%C3\%A30\%20b\%C3\%A1sica.> Acessado em: 10 de outubro de 2020. 
BRASIL. Presidência da República. Lei $n^{\circ}$ 13.005/2014, Brasília, DF, <Disponível em: PNE-http://pne.mec.gov.br/18-planos-subnacionais-deeducacao/543-plano-nacional-de-educacao-lei-n-13-005-2014.> Acesso em: 10 de outubro de 2020.

BRASIL. Supremo Tribunal Federal. Súmula $n^{\circ} 14$. In: Súmulas.

São Paulo: Associação dos Advogados do Brasil, $2005 . \quad$ p. 16.http://www3.tst.jus.br/jurisprudencia/Sumulas_com_indice/Sumulas_Ind _51_100.html\#SUM-90

BRASIL. Tribunal Superior do Trabalho (TST). Jurisprudência 2. Direito processual do trabalho Súmula $n^{\circ} 331$. lei 13.429/17, Brasília, DF, $<$ Disponível

em: http://www3.tst.jus.br/jurisprudencia/Sumulas_com_indice/Sumulas_I nd_301_350.html.> Acessado em: 10 de outubro de 2020.

BRASIL. Lei no 13.089/2015. Estatuto da Metrópole. Disponível em: <http://www.planalto.gov.br/ccivil_03/_Ato2015-

2018/2015/Lei/L13089.htm>. Acesso em 18 de julho de 2016.

Brumes, K. R., \& da Silva, M. (2011). Migração e cidades médias: uma análise de Uberlândia - DOI 10.5216/ag.v4i11.11959. Ateliê Geográfico, 4(3), 64-87. https://doi.org/10.5216/ag.v4i3.16644

CACETE, Núria Hanglei. Breve história do ensino superior brasileiro e da formação de professores para a escola secundária I. Educ. Pesqui., São Paulo, v. 40, n. 4, p. 1061-1076, out./dez. 2014.

CATANI, Denice Barbara. Estudos de história da profissão docente. In: LOPES, Eliana Marta Teixeira, FARIA FILHO, Luciano Mendes, VEIGA, Cynthia Greive. (orgs.). 500 anos de educação no Brasil. $2^{a} e d$. Belo Horizonte: Autêntica, 2000, p. 585-597.

CIAVATTA, Maria. O conhecimento histórico e o problema teóricometodológico das mediações. In: FRIGOTTO, Gaudêncio e CIAVATTA, Maria (org). Teoria e Educação no labirinto do capital. São Paulo: Expressão Popular, 2014, pp. 191- 229.

CNTE. Confederação Nacional dos Trabalhadores da Educação. Notas públicas: metade dos estados não paga o piso salarial, 23 de março 2016. Disponível em:

https://www.cnte.org.br/index.php/menu/comunicacao/posts/cnte-namidia/63194-mais-da-metade-dos-estados-nao-paga-o-piso-salarial-aosprofessores-diz-cnte Acessado em 20 de julho de 2020.

Notas públicas: metade dos estados não paga o piso salarial, 27 de janeiro de 2020 Disponível em: https://www.cnte.org.br/index.php/menu/comunicacao/posts/notaspublicas/72709-o-piso-do-magisterio-e-instrumento-de-valorizacao-dacarreira-profissional-e-precisa-ser-respeitado-pelos-gestorespublicosAcessado em 20 de julho de 2020. 
CORRÊA, R. L. Espaço: um conceito chave da Geografia. In: CASTRO, I. E.; GOMES, P. C.; CORRÊA, R. L. (Org.) Geografia: conceitos e yemas. 2. ed. Rio de Janeiro: Bertrand Brasil, 2000. p.15-47.

CRESSWELL, Tim. On the move: mobility in the modern western world. New York: Routledge, 2006. 327p. Disponível em: https://www.researchgate.net/publication/255703195_On_the_move_Mobil ity_in_the_modern_western_world. Acessado em janeiro de 2020.

Towards a politic of mobility, 2010. Disponível em: https://journals.sagepub.com/doi/10.1068/d11407. Acessado em janeiro de 2020.

DRUCK, M. G. Flexibilização e Precarização: formas contemporâneas de dominação do trabalho. Cadernos do CRH, Salvador, v. 37, p. 11-22, 2002.

ELDEN, Stuart. Legal terrain: the political materiality of territory. London Review of International Law, Volume 0, Issue 0, 2017, 1 of 26. Disponível em: https://progressivegeographies.files.wordpress.com/2017/10/elden2017-legal-terrain.pdf Acessado em janeiro de 2020.

FÉLIX, Gil. Mobilidade e superexploração do trabalho: o enigma da circulação. São Paulo, 2019.

FERNANDES, H.C; ORSO, P.J. O trabalho docente: pauperização, precarização ou proletarização. <Disponível em: www.histedbr.fe.unicamp.br/acer_histedbr/jornada/jornada9/_files/PyzH1G vQ.pdf> Acessado em: 20 de maio de 2019.

FERREIRA, Alvaro, RUA,João, e MATTOS, Regina Célia. Desaflos da metropolizaçâo / Organizadores: Alvaro Ferreira, loão Rua e Regina Célia de Mattos. - 1. Ed. - Rio de laneiro : Consequência, 2015.

FOUCAULT, Michel. O corpo utópico; heterotopias. Posfácio de Daniel Defert. São Paulo: n-1 Edições, 2013, pp. 19-30.

FOUCAULT, Michel. Vigiar e punir: história da violência nas prisões. Petrópolis, Rj: Vozes, 2009, pp.09-33; 131-150; 186-198.

FRIGOTTO, Gaudêncio. As novas e velhas faces da crise do capital e o labirinto dos referenciais teóricos. In: FRIGOTTO, Gaudêncio e CIAVATTA, Maria (org). Teoria e Educação no labirinto do capital. São Paulo: Expressão Popular, 2014, pp. 29-69.

GAUDEMAR, J.-P. 1979. Movilidad del trabajo y acumulación de capital. México : Era

GATTI, Bernadette, BARRETO, Elba Siqueira de Sá. Professores do Brasil: impasses e desafios. UNESCO, 2009, Disponível em: https://unesdoc.unesco.org/ark:/48223/pf0000184682. Acessado em julho de 2018. 
GOMES, L; BRITO, J. Desafios e possibilidades ao trabalho docente e a sua relação com a saúde. UERJ: estudos e pesquisas em psicologia. v.6, $\mathrm{n} 1$, 2006.

Disponível em:http://www.revispsi.uerj.br/v6n1/artigos/PDF/v6n1a05.pdf acessado em 01/10/2017.

HAESBAERT. Rogério.Território e multiterritorialidade: um debate. Geographia, Niterói, UFF, Ano 9, n. 17, 19-46, 2007.

Harvey, David. (1980). A justiça social e a cidade. São Paulo: Hucitec

Harvey, David. (1992). Condição pós-moderna: Uma pesquisa sobre as origens da mudança cultural. São Paulo: Loyola.

HARVEY, David. O direito à cidade. Lutas Sociais, São Paulo: NEILS Núcleo de Estudos de Ideologias e Lutas Sociais, n. 29, 2012.

HELLER, Agnes. O cotidiano e a História. São Paulo: Paz e terra, 2008. Capítulo 2 - Estrutura da vida cotidiana, pp. 31-61; Capítulo 3 - Sobre os preconceitos, pp. 63-88.

Instituto Nacional de Estudos e Pesquisas Educacionais Anísio Teixeira. Relatório nacional : pesquisa internacional sobre ensino e aprendizagem : Talis 2018 : primeira parte. - Brasília : Inep, 2019.http://download.inep.gov.br/informacoes_estatisticas/indicadores_ed ucacionais/2014/docente_esforco/nota_tecnica_indicador_docente_esforc o.pdf> Acesso em: 03 de jul 2020.

INSTITUTO NACIONAL DE ESTUDOS E PESQUISAS EDUCACIONAIS ANÍSIO TEIXEIRA. Censo Escolar: Sinopse Estatística 2019. Disponível em:<http://inep.gov.br/sinopses-estatisticas-daeducacao-basica>. Acesso em setembro de 2020

INSTITUTO NACIONAL DE ESTUDOS E PESQUISAS EDUCACIONAIS ANÍSIO TEIXEIRA. Censo Escolar: Sinopse Estatística 2018. Disponível em:<http://inep.gov.br/sinopses-estatisticas-daeducacao-basica>. Acesso em setembro de 2019

INSTITUTO NACIONAL DE ESTUDOS E PESQUISAS EDUCACIONAIS ANÍSIO TEIXEIRA. Censo Escolar: Sinopse Estatística 2017. Disponível em:<http://inep.gov.br/sinopses-estatisticas-daeducacao-basica>. Acesso em setembro de 2019

INSTITUTO NACIONAL DE ESTUDOS E PESQUISAS EDUCACIONAIS ANÍSIO TEIXEIRA. Censo Escolar: Sinopse Estatística 2016. Disponível em:<http://inep.gov.br/sinopses-estatisticas-daeducacao-basica>. Acesso em setembro de 2019

INSTITUTO NACIONAL DE ESTUDOS E PESQUISAS EDUCACIONAIS ANÍSIO TEIXEIRA. Censo Escolar: Sinopse Estatística 2015. Disponível em:<http://inep.gov.br/sinopses-estatisticas-daeducacao-basica>. Acesso em setembro de 2019 
INSTITUTO NACIONAL DE ESTUDOS E PESQUISAS EDUCACIONAIS ANÍSIO TEIXEIRA. Censo Escolar: Sinopse Estatística 2014. Disponível em:<http://inep.gov.br/sinopses-estatisticas-daeducacao-basica>. Acesso em setembro de 2019.

INSTITUTO NACIONAL DE ESTUDOS E PESQUISAS EDUCACIONAIS ANÍSIO TEIXEIRA. Censo Escolar: Sinopse Estatística 2013. Disponível em:<http://inep.gov.br/sinopses-estatisticas-daeducacao-basica>. Acesso em setembro de 2019

INSTITUTO NACIONAL DE ESTUDOS E PESQUISAS EDUCACIONAIS ANÍSIO TEIXEIRA. Censo Escolar: Sinopse Estatística 2012. Disponível em:<http://inep.gov.br/sinopses-estatisticas-daeducacao-basica>. Acesso em setembro de 2019

INSTITUTO NACIONAL DE ESTUDOS E PESQUISAS EDUCACIONAIS ANÍSIO TEIXEIRA. Censo Escolar: Sinopse Estatística 2011. Disponível em:<http://inep.gov.br/sinopses-estatisticas-daeducacao-basica>. Acesso em setembro de 2019

INSTITUTO NACIONAL DE ESTUDOS E PESQUISAS EDUCACIONAIS ANÍSIO TEIXEIRA. Censo Escolar: Sinopse Estatística 2010. Disponível em:<http://inep.gov.br/sinopses-estatisticas-daeducacao-basica>. Acesso em setembro de 2019

INSTITUTO NACIONAL DE ESTUDOS E PESQUISAS EDUCACIONAIS ANÍSIO TEIXEIRA. Microdados do Censo Escolar - 2018. Disponível em: http://portal.inep.gov.br/microdados.

. INSTITUTO NACIONAL DE ESTUDOS E PESQUISAS EDUCACIONAIS ANÍSIO TEIXEIRA. Relatório nacional : pesquisa internacional sobre ensino e aprendizagem : Talis 2018 : primeira parte. Brasília : Inep, 2019. Disponível em: http://portal.inep.gov.br/informacaoda-publicacao/-/asset_publisher/6JYIsGMAMkW1/document/id/6726718. Acesso em outubro de 2019.

INSTITUTO NACIONAL DE ESTUDOS E PESQUISAS EDUCACIONAIS ANÍSIO TEIXEIRA. Relatório Education at a Glance: EAG $2018 . \quad$ OCDE. Disponível em: http://download.inep.gov.br/acoes_internacionais/eag/documentos/2018/P anorama_da_Educacao_2018_do_Education_a_glance.pdf

IBGE - Instituto Brasileiro de Geografia e Estatística. Arranjos populacionais e concentrações urbanas do Brasil. Rio de Janeiro: IBGE, $2015 . \quad$ Disponível em http://www.ibge.gov.br/apps/arranjos_populacionais/2015/pdf/publicacao.p df. Acesso em 10 out. 2020.

IBGE - Instituto Brasileiro de Geografia e Estatística. Coordenação de Índices de Preços. Para compreender o INPC : um texto simplificado - 7. 
ed. - Rio de Janeiro : IBGE, 2016. <Disponível em: https://biblioteca.ibge.gov.br/visualizacao/livros/liv97035.pdf.> Acessado em: 10 de outubro de 2020.

IBGE - Instituto Brasileiro de Geografia e Estatística. Índice Nacional de Preços ao Consumidor [INPC]. Variação acumulada no ano durante o Plano Real (\%), dezembro 1995 - dezembro 2019.<Disponível em: https://www.ibge.gov.br/estatisticas/economicas/precos-e-custos/9258indice-nacional-de-precos-ao-consumidor. $h t m l$ ?edicao $=29107 \& \mathrm{t}=$ series historicas.> Acesso em: 05 de ago 2020.>

IBGE - Instituto Brasileiro de Geografia e Estatística. ISSN 0104-3145 Censo demogr., Rio de Janeiro, p.1-205 2010. <Disponível em: https://biblioteca.ibge.gov.br/visualizacao/periodicos/545/cd_2010_educac ao_e_deslocamento.pdf.> Acesso em: 20 ago 2020.

Base Sidra: pesquisa sobre deslocamento. Disponível em: https://sidra.ibge.gov.br/pesquisa/censo-demografico/demografico2010/amostra-educacao-e-deslocamento. Acesso em: 20 ago 2020.

Para compreender o INPC : um texto simplificado / IBGE, Coordenação de Índices de Preços. - 7. ed. - Rio de Janeiro : IBGE, 2016. 62 p. ISBN 978-85-240-4379-6. https://biblioteca.ibge.gov.br/visualizacao/livros/liv97035.pdf

. Pesquisa Nacional por Amostra de Domicílios - PNAD 2020. Rio de Janeiro: IBGE, 2020. <Disponível em: https://www.ibge.gov.br/estatisticas/sociais/trabalho/9171-pesquisanacional-por-amostra-de-domicilios-continua-mensal.html?=\&t=0-que-e.> Acesso em: 10 de outubro de 2020.

LEFEBVRE, Henri. Espaço e Política. Tradução Margarida Maria de Andrade e Sérgio Martins. Belo Horizonte: Editora UFMG, 2008.

LIMA, Elias Lope de. O sujeito da atividade prática. Encruzilhadas geográficas: notas sobre a compreensão do sujeito na teoria social crítica. Rio de Janeiro: Record, 2008, pp. 15-26.

LUKÁCS, Gyögy. Para uma ontologia do ser social II. São Paulo: Boitempo, 2013. Parte I, 1, pp. 45-82.

MARANDOLA, Eduardo Jr. Mobilidades contemporâneas: distribuição espacial da população, vulnerabilidade e espaços de vida nas aglomerações urbanas. In Mobilidade espacial da população: desafios teóricos e metodológicos para o seu estudo / José Marcos Pinto da Cunha (Org.). - Campinas: Núcleo de Estudos de População-Nepo/Unicamp; 2011.

MARX, Karl. Trabalho assalariado e capital \& salário, preço e lucro. São Paulo, expressão popular, 2010, p. 144.

MARX. K. O Capital. São Paulo. Abril, Cultural, 1983, v.I 
MASSEY, Doreen. Pelo espaço: uma nova política da espacialidade. Rio de Janeiro: Bertrand Brasil, 2008.

MCMASTER, R.; SHEPPARD, E. (2004) Introduction. In Sheppard, E. and McMaster, R., editors, Scale and geographic inquiry, Malden, MA: Blackwell, 1-22.

MÉSZÁROS, István. A educação para além do capital. São Paulo: Boitempo, 2008, 2a edição.

MÉSZÁROS, István. A teoria da alienação em Marx. São Paulo: Boitempo, 2006. Capítulo III - Estrutura conceitual da teoria da alienação de Marx, pp. 91-111; Capítulo IV - Aspectos econômicos, pp. 115-138; Capítulo VAspectos políticos, pp. 139-148; Capítulo VI Aspectos ontológicos e morais, pp. 149-172.

MÉSZÁROS, István. Para além do capital. São Paulo: Boitempo, 2002, pp.94- 106; 175-188; 267-310.

MORIN, Edgar. Os sete saberes necessários à educação do futuro. Tradução de Catarina Eleonora F. da Silva e Jeanne Sawaya; $2^{a}$ edição São Paulo: Cortez; Brasília, DF: UNESCO, 2000.

NETTO, José Paulo \& CARVALHO, Maria do Carmo Brant de. Cotidiano: conhecimento e crítica. São Paulo: Cortez, 2012.

NÓVOA, António. Les temps des professeurs - analuse sócio-historique de la profession enseignante au Portugal (XVIle- XXe sièle). Lisboa: Instituto Nacional de Investigação Científica, 1987, v. I-II, p.75-76.

OLIVEIRA, Antônio Tadeu. A mobilidade espacial da população e as transformações do processo produtivo no Brasil pós-1980: o caso do Estado do Rio de Janeiro. Tese de doutorado. Campinas, 2009. Disponível em:

http://repositorio.unicamp.br/jspui/bitstream/REPOSIP/280907/1/Oliveira AntonioTadeuRibeirode_D.pdf Acessado em julho de 2020.

PASSOS, Carmensita. Trabalho Docente: características e especificidades." Nota de Aula, Fortaleza (2002). <Dísponível em: http://www.virtual.ufc.br/solar/aula_link/llesp/A_a_H/didatica_l/aula_0 1/imagens/03/trabalho_docnte.pdf.> Acesso em: 20 de out 2020

PEREIRA, Júlio Emílio Diniz. A situação atual dos cursos de licenciatura no Brasil frente à hegemonia da educação mercantil e empresarial. Revista Eletrônica de Educação, v. 9, n. 3, p. 273-280, 2015.

POSTONE, Moische. Tempo, trabalho e dominação social: uma reinterpretação da teoria crítica de Marx. São Paulo: Boitempo, 2014, Parte I, 1, pp. 17-59. 
PÓVOA-NETO, H. Migrações internas e mobilidade do trabalho no Brasil atual: novos desafios para a análise. Revista Experimental. São Paulo: FFLCH/USP, 2, março, 11-24, 1997.

RAVENSTEIN. Ernst.G. As leis da migração. In: MOURA, Helio A. de (Coord.). Migração interna: textos selecionados. Fortaleza: BNB, 1980, p. 19-88.

RIO DE JANEIRO, Resolução Seeduc N5833, 10 de fevereiro de 2020. Ampliação da jornada de trabalho, mediante o pagamento de gratificações por lotação prioritária/GLP, aos professores da secretaria de estado de educação. <Disponível em: http://www.fazenda.rj.gov.br/sefaz/content/conn/UCMServer/path/Contribu tion\%20Folders/site_fazenda/Subportais/PortalGestaoPessoas/Legisla\%C 3\%A7\%C3\%B5es\%20SILEP/Legisla\%C3\%A7\%C3\%B5es/2020/Resolu\% C3\%A7\%C3\%B5es/RESOLU\%C3\%87\%C3\%830\%20N\%C2\%BA\%20583 3\%20DE\%2010\%20DE\%20FEVEREIRO\%20DE\%202020_REGULAMEN TA\%200\%20REGIME\%20DE\%20AMPLIA\%C3\%87\%C3\%830\%20DA\%2 OJORNADA\%20DE\%20TRABALHO\%20DOS\%20PROFESSORES\%20D A\%20SEEDUC.pdf? Ive> Acesso em: 20 de set 2020.

ROSSO, Sadi Dal. O ardil da flexibilidade: os trabalhadores e a teoria do valor: - 1.ed. São Paulo: Boitempo, 2017.

RUA, João. Desenvolvimento, Espaço e Sustentabilidade. IN: RUA, João (org.) Paisagem, Espaço e Sustentabilidade. Rio de Janeiro: PUC-Rio, 2007.

RUA, João. Desenvolvimento e sustentabilidade: uma perspectiva geográfica. In: OLIVEIRA, M. P. COELHO, M.C.N. CORRÊA, A, M. O Brasil, a América Latina e o Mundo. Espacialidades Contemporâneas. Rio de Janeiro: Lamparina. 2008.

SANTOS, Milton. A natureza do espaço. Cap. 1, 2, 3, 14 e 15. 2006.

. O Espaço do Cidadão. São Paulo: Editora Nobel, 1987.

Técnica, espaço e tempo: a globalização e o meio técnicocientífico- informacional. São Paulo. HUCITEC. 1994

SANTOS, Sheila Daniela Medeiros. A precarização do trabalho docente no Ensino Superior dos impasses às possibilidades de mudanças. Curitiba, Brasil, Educ. rev. 2012, n.46, pp.229-244.

SAVIANI, Demerval. Escola e Democracia. São Paulo: Cortez/Autores Associados, 1987.

SENNETT, Richard. Carne e pedra: o corpo e a cidade na civilização ocidental. Rio de Janeiro: Record, 2008, pp. 15-26. 
SILVA, Amanda Moreira. A precarização do trabalho docente no século XXI: o precariado professoral e o professorado estável formal sob a lógica privatista empresarial nas redes públicas brasileiras. Rio de Janeiro, 2018.

SILVA,Suzana Campos. A política de fechamento de escolas estaduais no rio de janeiro e suas consequências socioespaciais, 14ํㅡㄹ Encontro Nacional de Prática de Ensino de Geografia 14ํㅡㄹ Encontro Nacional de Prática de Ensino de Geografia Políticas, Linguagens e Trajetórias Universidade Estadual de Campinas, 29 de junho a 4 de julho de 2019.

SOJA, Edward William. Geografias pós-modernas: a reafirmação do espaço na teoria social crítica. Rio de Janeiro: Jorge Zahar Ed., 1999

SOUZA, Marcelo Lopes de (2013). Os conceitos fundamentais da pesquisa sócio-espacial. 1 ed. - Rio de Janeiro: Bertrand Brasil. 320 p.

SOUZA, Fábio Araujo, CAMARGO, Rubens Barbosa. Vinculação Constitucional De Recursos Mínimos Na Educação Estadual Do Rio De Janeiro 1995-2015(DOI: 10.12957/Teias.2017.27776 Teias v. 18 • n. 49 • 2017(abr./jun.):

STANDING, Guy. O precariado : a nova classe perigosa / Guy Standing ; tradução Cristina Antunes. 1. ed.; 1. reimp, - Belo Horizonte : Autêntica Editora, 2014 (Invenções Democráticas, v. IV).

TARDIF, Maurice. A profissionalização do ensino passados trinta anos:dois passos para a frente, três para trás . Educ. Soc. [online]. 2013, vol.34, n.123, pp.551-571. ISSN 0101-733.

TARDIF, Maurice; LESSARD, Claude. O Trabalho Docente: elementos para uma teoria da docência como profissão de interações humanas. Petrópolis, RJ: Vozes, 2009.

TAVARES, Maria Augusta. Os fios (in)visíveis da produção capitalista: informalidade e precarização do trabalho. São Paulo: Cortez, 2004. Capítulo I e II, pp. 27-130.

Todos pela educação. Anuário Brasileiro da Educação Básica, ABEB 2018, Editora Moderna, São Paulo, 2019. Disponível em: https://www.todospelaeducacao.org.br/_uploads/_posts/302.pdf. Acessado em agosto de 2018.

VIRILIO, Paul. O Espaço Critico. Ano: 1993. Editora: 34. 


\section{Anexos}

\section{Anexo 1: Perguntas e Respostas do questionário}

\section{1) Sexo}

\begin{tabular}{|c|c|c|}
\hline OPÇÕES DE RESPOSTA & RESPOSTAS & \\
\hline Feminino & $55.84 \%$ & 86 \\
\hline Masculino & $44.16 \%$ & 68 \\
\hline Outra definição & $0.00 \%$ & 0 \\
\hline TOTAL & & 154 \\
\hline
\end{tabular}

2) Faixa etária

\begin{tabular}{|c|c|c|}
\hline OPÇÕES DE RESPOSTA & RESPOSTAS & \\
\hline 20 a 29 anos & $15.58 \%$ & 24 \\
\hline 30 a 39 anos & $35.71 \%$ & 55 \\
\hline 40 a 49 anos & $25.97 \%$ & 40 \\
\hline 50 a 59 anos & $14.29 \%$ & 22 \\
\hline 60 a 69 anos & $7.79 \%$ & 12 \\
\hline 70 anos ou mais & $0.65 \%$ & 1 \\
\hline TOTAL & & 154 \\
\hline
\end{tabular}

3) Qual o nível de escolaridade mais alto que você completou?

\begin{tabular}{|c|c|c|}
\hline OPÇŌES DE RESPOSTA & \multicolumn{2}{|c|}{ RESPOSTAS } \\
\hline Ensino médio & $0.65 \%$ & 1 \\
\hline Ensino médio - Formação de Professores & $1.30 \%$ & 2 \\
\hline Tecnólogo & $0.00 \%$ & 0 \\
\hline Ensino superior incompleto & $5.84 \%$ & 9 \\
\hline Ensino superior completo - Licenciatura na área de atuação & $29.22 \%$ & 45 \\
\hline Ensino superior completo - Licenciatura fora da área de atuaçăo & $3.90 \%$ & 6 \\
\hline Ensino superior completo - bacharelado na área de atuaçăo & $9.74 \%$ & 15 \\
\hline Ensino superior completo - bacharelado fora da área de atuaçăo & $1.30 \%$ & 2 \\
\hline Pós-graduaçăo lato sensu & $35.06 \%$ & 54 \\
\hline Pós-graduação stricto senso - mestrado & $22.08 \%$ & 34 \\
\hline Pós-graduaçăo stricto senso - doutorado & $4.55 \%$ & 7 \\
\hline pós doutorado & $0.65 \%$ & 1 \\
\hline Total de respondentes: 154 & & \\
\hline
\end{tabular}

4) Você atua como professor dedicação exclusiva em alguma rede de ensino que trabalha?

\begin{tabular}{|c|c|c|}
\hline OPÇŌES DE RESPOSTA & RESPOSTAS & \\
\hline Sim & $23.38 \%$ & 36 \\
\hline Não & $76.62 \%$ & 118 \\
\hline TOTAL & & 154 \\
\hline
\end{tabular}

5) Em quantas escolas e cursos você atua? 


\begin{tabular}{|c|c|c|}
\hline OPÇÕES DE RESPOSTA & RESPOS & \\
\hline Apenas uma escola da rede privada & $9.59 \%$ & 7 \\
\hline Apenas uma escola da rede municipal & $10.96 \%$ & 8 \\
\hline Apenas uma escola da rede estadual & $10.96 \%$ & 8 \\
\hline Apenas uma escola da rede federal & $1.37 \%$ & 1 \\
\hline Em duas ou mais escolas da mesma rede privada & $6.85 \%$ & 5 \\
\hline Em duas ou mais escolas da mesma rede municipal & $4.11 \%$ & 3 \\
\hline Em duas ou mais escolas da mesma rede estadual & $8.22 \%$ & 6 \\
\hline Em duas ou mais escolas de diferentes redes privadas & $6.85 \%$ & 5 \\
\hline Em duas ou mais escolas de diferentes redes municipais & $2.74 \%$ & 2 \\
\hline Em escolas da rede municipal e privada & $4.11 \%$ & 3 \\
\hline Em escolas da rede municipal e estadual & $19.18 \%$ & 14 \\
\hline Em escolas da rede municipal e federal & $1.37 \%$ & 1 \\
\hline Em escolas da rede estadual e privada & $8.22 \%$ & 6 \\
\hline Em escolas da rede estadual e federal & $0.00 \%$ & 0 \\
\hline Em escolas da rede federal e privada & $1.37 \%$ & 1 \\
\hline Outro (especifique) & $4.11 \%$ & 3 \\
\hline TOTAL & & 73 \\
\hline
\end{tabular}

\section{6) Séries que atua?}

\begin{tabular}{lll}
\hline OPÇÕES DE RESPOSTA & RESPOSTAS \\
\hline Ensino Fundamental $\left(6^{\circ}\right.$ ao $9^{\circ}$ ano) & $79.45 \%$ & 58 \\
\hline Ensino médio $\left(1^{\circ}\right.$ ao $3^{\circ}$ ano) & $68.49 \%$ & 50 \\
\hline Cursos Técnicos & $6.85 \%$ & 5 \\
\hline Cursos preparatórios & $17.81 \%$ & 13 \\
\hline Total de respondentes: 73 & & \\
\hline
\end{tabular}

\section{7) Disciplina que atua?}

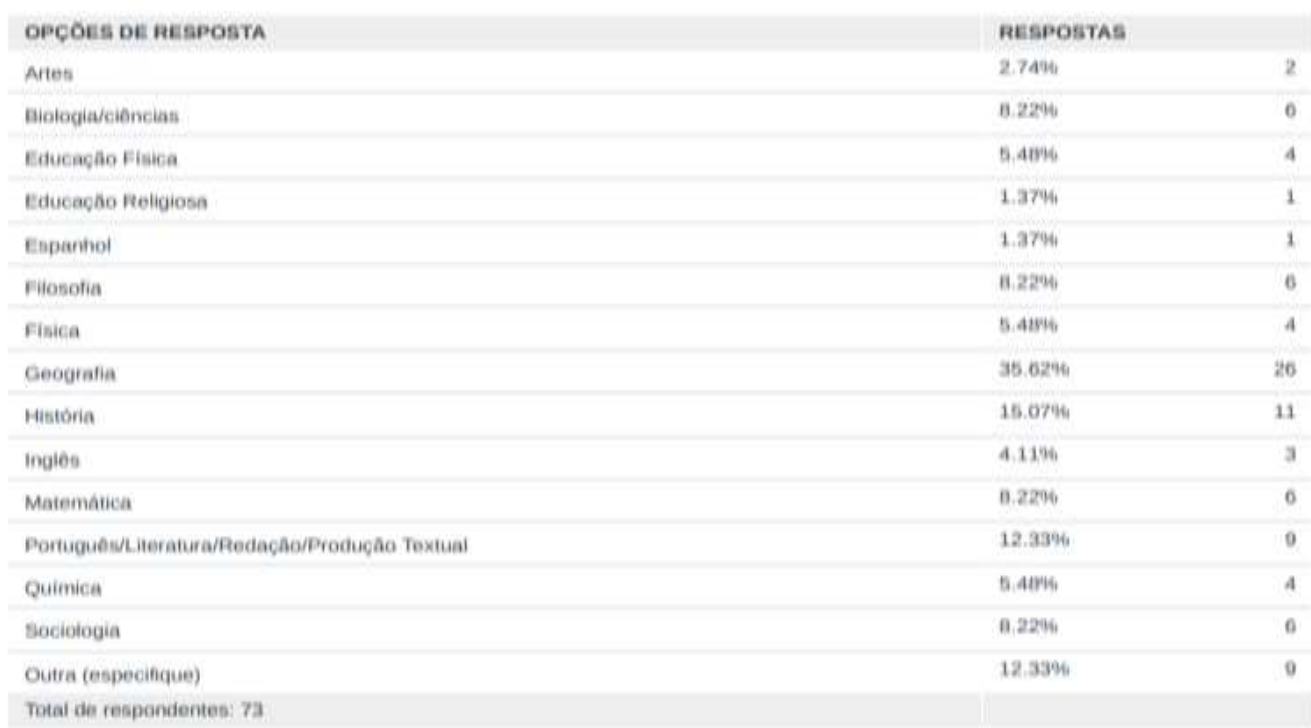

8) Há quanto tempo atua como professor? 


\begin{tabular}{|c|c|c|}
\hline OPÇÕES DE RESPOSTA & RESPOSTAS & \\
\hline 1.5 anos & $23.29 \%$ & 17 \\
\hline $6-10$ anos & $23.29 \%$ & 17 \\
\hline $11-15$ anos & $16.44 \%$ & 12 \\
\hline 16 a 20 anos & $17.81 \%$ & 13 \\
\hline Mais de 21 anos & $19.18 \%$ & 14 \\
\hline TOTAL & & 73 \\
\hline
\end{tabular}

9) A carreira de magistério é a sua principal fonte de renda?

\begin{tabular}{|c|c|c|}
\hline OPÇŌES DE RESPOSTA & \multicolumn{2}{|c|}{ RESPOSTAS } \\
\hline Sim, a única. & $85.71 \%$ & 12 \\
\hline Sim, mas trabalho em outra área também. & $14.29 \%$ & 2 \\
\hline Nẵo. & $0.00 \%$ & 0 \\
\hline TOTAL & & 14 \\
\hline
\end{tabular}

10) Qual a sua carga horária semanal como professor?

\begin{tabular}{|c|c|c|}
\hline OPCOES DE RESPOSTA & AESPOSTAS & \\
\hline Ale 20 horas & $17.01 \%$ & 13 \\
\hline de 20 a 30 horas & $27.40 \%$ & 20 \\
\hline de 30 a 40 horas & $26.03 \%$ & 19 \\
\hline de 40 a 50 horas & 17.8106 & 13 \\
\hline de 50 a 60 horas & $8.22 \%$ & 6 \\
\hline de 60 a 70 horas & $0.00 \%$ & 0 \\
\hline de 70 a 80 horas & $1.37 \%$ & 1 \\
\hline Mais de ao horas & $1.37 \% 6$ & 1 \\
\hline TOTAL. & & 73 \\
\hline
\end{tabular}

11) Você participa ou já participou de algum programa de hora extra na rede que leciona (GLP, Janela, outro)?

\begin{tabular}{|c|c|c|}
\hline OPÇŌES DE RESPOSTA & \multicolumn{2}{|c|}{ RESPOSTAS } \\
\hline Sim estou participando. & $36.99 \%$ & 27 \\
\hline Não, nunca. & $36.99 \%$ & 27 \\
\hline Sim, já participei (especifique o ano, o programa e a rede) & $26.03 \%$ & 19 \\
\hline TOTAL & & 73 \\
\hline
\end{tabular}

12) Sobre as escolas que você trabalha, informe:

\begin{tabular}{|c|c|c|}
\hline \multirow{2}{*}{$\begin{array}{l}\text { OPÇÕES DE RESPOSTA } \\
\text { nome }\end{array}$} & \multicolumn{2}{|c|}{ RESPOSTAS } \\
\hline & $100.00 \%$ & 73 \\
\hline rede ( $P$ - privada, $M$ - municipal, $E$ - estadual, $F$ - federal) & $100.00 \%$ & 73 \\
\hline endereço (bairro e municipio) & $100.00 \%$ & 73 \\
\hline sua carga horária de trabalho (por semana) & $2.74 \%$ & 2 \\
\hline disciplina(s) & $2.74 \%$ & 2 \\
\hline série(s) & $2.74 \%$ & 2 \\
\hline turno (M - manhă, T - Tarde, N- Noite) & $100.00 \%$ & 73 \\
\hline tipo de contrato de trabalho (funcionáric & $100.00 \%$ & 73 \\
\hline
\end{tabular}

13) Qual o tempo médio de deslocamento de casa para o trabalho, por semana? 


\begin{tabular}{llr}
\hline OPÇÕES DE RESPOSTA & RESPOSTAS & 45 \\
\hline Até 5 horas & $61.64 \%$ & 16 \\
\hline $5-10$ horas & $21.92 \%$ & 9 \\
\hline $10-15$ horas & $12.33 \%$ & 2 \\
\hline $15-20$ horas & $2.74 \%$ & 1 \\
\hline Acima de 20 horas & $1.37 \%$ & 73 \\
\hline TOTAL & & 1 \\
\hline
\end{tabular}

14) Qual o tempo de deslocamento interescolas, por semana?

\begin{tabular}{|c|c|c|}
\hline OPÇŌES DE RESPOSTA & RESPOSTAS & \\
\hline Até 5 horas & $86.30 \%$ & 63 \\
\hline $5-10$ horas & $9.59 \%$ & 7 \\
\hline $10-15$ horas & $4.11 \%$ & 3 \\
\hline $15-20$ horas & $0.00 \%$ & 0 \\
\hline Acima de 20 horas & $0.00 \%$ & 0 \\
\hline TOTAL & & 73 \\
\hline
\end{tabular}

15) Você necessitou mudar de residência por causa da distância para o trabalho?

\begin{tabular}{|c|c|c|}
\hline OPÇÖES DE RESPOSTA & RESPOSTAS & \\
\hline Sim. & $17.65 \%$ & 3 \\
\hline Não. & $82.35 \%$ & 14 \\
\hline TOTAL & & 17 \\
\hline
\end{tabular}

16) Você necessitou morar/dormir alguns dias da semana em outra residência por causa da distância para o trabalho?

\begin{tabular}{l|r}
\hline OPÇÕES DE RESPOSTA & \multicolumn{1}{c}{ RESPOSTAS } \\
\hline Sim, atualmente moro/divido quarto/casa/vaga alguns dias da semana para ficar próximo ao trabalho, & $0.00 \%$ \\
\hline Hoje não, mas já necessitei. & $35.29 \%$ \\
\hline Não. & $64.71 \%$ \\
\hline $\begin{array}{l}\text { Outro (especifique) } \\
\text { TOTAL }\end{array}$ & $0.00 \%$ \\
\hline
\end{tabular}

17) Você já realizou permuta ou transferência?

\begin{tabular}{l|l|l}
\hline OPÇŎES DE RESPOSTA & \multicolumn{2}{l}{ RESPOSTAS } \\
\hline Sim, para ficar próximo ao local que moro. & $28.57 \%$ & 4 \\
\hline Sim, por outros motivos. & $7.14 \%$ & 1 \\
\hline Não, porém já solicitei. & $7.14 \%$ & 1 \\
\hline Nåo. & $57.14 \%$ & 8 \\
TOTAL & & 14 \\
\hline
\end{tabular}

18) Você necessitou adquirir um veículo para se locomover para o trabalho?

\begin{tabular}{l|l|l} 
OPÇÕES DE RESPOSTA & \multicolumn{2}{l}{ RESPOSTAS } \\
\hline Sim, para ficar próximo ao local que moro. & $28.57 \%$ & 4 \\
\hline Sim, por outros motivos. & $7.14 \%$ & 1 \\
\hline Não, porém já solicitei. & $7.14 \%$ & 1 \\
\hline Não. & $57.14 \%$ & 8 \\
TOTAL & & 14
\end{tabular}

19) $\mathrm{A}(\mathrm{s})$ escola(s)/curso(s) ou rede(s) principal que você trabalha oferece(m) algum tipo de suporte para o deslocamento dos professores? 


\begin{tabular}{|c|c|c|}
\hline OPÇÕES DE RESPOSTA & \multicolumn{2}{|c|}{ RESPOSTAS } \\
\hline Sim, oferece ônibus especial (trajeto casa-escola). & $0.00 \%$ & 0 \\
\hline Sim, oferece auxilio transporte. & $58.82 \%$ & 10 \\
\hline Năo. & $23.53 \%$ & 4 \\
\hline Não, porém já ofereceu. & $5.88 \%$ & 1 \\
\hline Sim, outro. & $11.76 \%$ & 2 \\
\hline TOTAL & & 17 \\
\hline
\end{tabular}

20) Durante seu deslocamento você exerce alguma atividade relacionada ao seu trabalho?

\begin{tabular}{lll}
\hline OPÇÕES DE RESPOSTA & RESPOSTAS & \\
Sim, planejamento de aula & $20.55 \%$ & 15 \\
\hline Sim, correçăo de prova & $28.77 \%$ & 21 \\
\hline Sim, leitura de livro didático ou acadêmico & $32.88 \%$ & 24 \\
\hline Sim, planejamento de atividades & $32.88 \%$ & 24 \\
\hline Sim, outro & $13.70 \%$ & 10 \\
\hline Năo & $45.21 \%$ & 33
\end{tabular}

Total de respondentes: 73

21) As perguntas abaixo são classificatórias e variam em uma escala de 1 a 4 , sendo 1 nada e 4 muito.

\begin{tabular}{|c|c|c|c|c|c|c|}
\hline & NADA & POUCO & $\begin{array}{l}\text { MAIS } \\
\text { OU } \\
\text { MENOS }\end{array}$ & MUITO & TOTAL & $\begin{array}{l}\text { MÉDIA } \\
\text { PONDERADA }\end{array}$ \\
\hline $\begin{array}{l}\text { Quanto você gostaria de trabalhar em apenas uma rede de } \\
\text { ensino ou em apenas uma escola? }\end{array}$ & $\begin{array}{r}0.00 \% \\
0\end{array}$ & $\begin{array}{r}0.00 \% \\
0\end{array}$ & $\begin{array}{r}0.00 \% \\
0\end{array}$ & $\begin{array}{r}100.00 \% \\
2\end{array}$ & 2 & 4.00 \\
\hline $\begin{array}{l}\text { Você acredita que trabalhar em apenas uma escola em } \\
\text { regime de dedicação exclusiva contribui para melhorar sua } \\
\text { condiçăo de trabalho? }\end{array}$ & $\begin{array}{r}5.48 \% \\
4\end{array}$ & $\begin{array}{r}0.00 \% \\
0\end{array}$ & $\begin{array}{r}26.03 \% \\
19\end{array}$ & $\begin{array}{r}68.49 \% \\
50\end{array}$ & 73 & 3.58 \\
\hline $\begin{array}{l}\text { Quanto que a mobilidade interescolas impacta no seu } \\
\text { trabalho enquanto docente? }\end{array}$ & $\begin{array}{r}11.27 \% \\
8\end{array}$ & $\begin{array}{r}9.86 \% \\
7\end{array}$ & $\begin{array}{r}36.62 \% \\
26\end{array}$ & $\begin{array}{r}42.25 \% \\
30\end{array}$ & 71 & 3.10 \\
\hline
\end{tabular}

\section{Anexo 2: número de escolas na RMRJ}

\begin{tabular}{|c|c|c|c|c|c|}
\hline \multicolumn{6}{|c|}{ ESCOLAS DA MMRJ - 2018} \\
\hline & \multicolumn{4}{|c|}{ TP_DEPENDENCIA } & \multirow[b]{2}{*}{ Total } \\
\hline CIDADE & FEDERAL & ESTADUAL & MUNICIPAL & PRIVADA & \\
\hline BELFORD ROXO & 0 & 40 & 34 & 49 & 123 \\
\hline $\begin{array}{l}\text { DUQUE DE } \\
\text { CAXIAS }\end{array}$ & 2 & 85 & 67 & 108 & 262 \\
\hline GUAPIMIRIM & 0 & 3 & 8 & 4 & 15 \\
\hline ITABORAÍ & 0 & 15 & 31 & 24 & 70 \\
\hline JAPERI & 0 & 9 & 11 & 7 & 27 \\
\hline MAGÉ & 0 & 19 & 40 & 21 & 80 \\
\hline MARICÁ & 0 & 9 & 16 & 16 & 41 \\
\hline MESQUITA & 0 & 11 & 12 & 22 & 45 \\
\hline NILOPOLIS & 1 & 12 & 10 & 27 & 50 \\
\hline NITERÓI & 2 & 43 & 12 & 91 & 148 \\
\hline NOVA IGUAÇU & 1 & 82 & 50 & 117 & 250 \\
\hline QUEIMADOS & 0 & 12 & 10 & 10 & 32 \\
\hline $\begin{array}{l}\text { RIO DE } \\
\text { JANEIRO }\end{array}$ & 16 & 307 & 633 & 806 & 1762 \\
\hline
\end{tabular}




\begin{tabular}{|l|l|l|l|l|l|}
$\begin{array}{l}\text { SÃO JOÃO DE } \\
\text { MERITI }\end{array}$ & 1 & 75 & 34 & 136 & 246 \\
\hline SÃO GONÇALO & 0 & 40 & 15 & 74 & 129 \\
\hline TANGUÁ & 0 & 2 & 7 & 2 & 11 \\
\hline TOTAL & 23 & 764 & 990 & 1514 & 3291 \\
\hline
\end{tabular}

Anexo 3: distribuição docente por rede de ensino, sexo e faixa etária na MMRJ

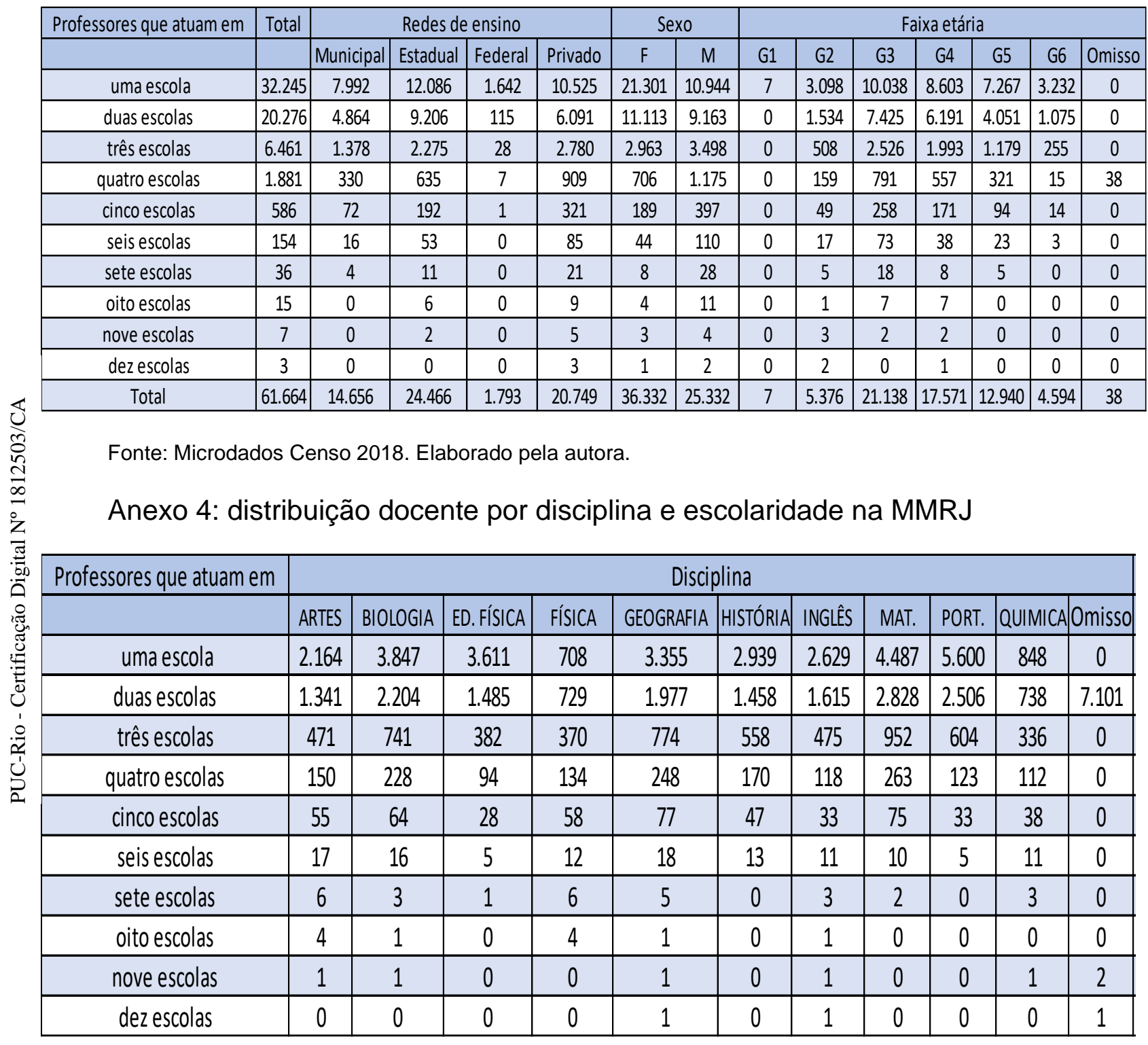

Fonte: Microdados Censo 2018. Elaborado pela autora. 
Anexo 5: distribuição docente por tipo de contratação na MMRJ

\begin{tabular}{|c|c|c|c|c|c|}
\hline Professores que atuam em & \multicolumn{5}{|c|}{ Tipo de contratação } \\
\hline & Concursado & Temporário & Terceirizado & CLT & Omisso \\
\hline uma escola & 21.017 & 683 & 18 & 2 & 10.525 \\
\hline duas escolas & 13.560 & 619 & 2 & 4 & 6.091 \\
\hline três escolas & 3.493 & 186 & 1 & 1 & 2.780 \\
\hline quatro escolas & 901 & 70 & 1 & 0 & 909 \\
\hline cinco escolas & 247 & 17 & 0 & 0 & 321 \\
\hline seis escolas & 66 & 3 & 0 & 0 & 85 \\
\hline sete escolas & 14 & 1 & 0 & 0 & 21 \\
\hline oito escolas & 5 & 1 & 0 & 0 & 10 \\
\hline nove escolas & 2 & 0 & 0 & 0 & 5 \\
\hline dez escolas & 0 & 0 & 0 & 0 & 3 \\
\hline Total & 39.305 & 1.580 & 22 & 7 & 20.750 \\
\hline
\end{tabular}

Fonte: Microdados Censo 2018. Elaborado pela autor 